\title{
Low-Level Waste Disposal Alternatives Analysis Report
}

\author{
Timothy Carlson \\ Roy Grant \\ Joan Connolly \\ Peggy Hinman
}

Charles Marcinkiewicz

September 2006

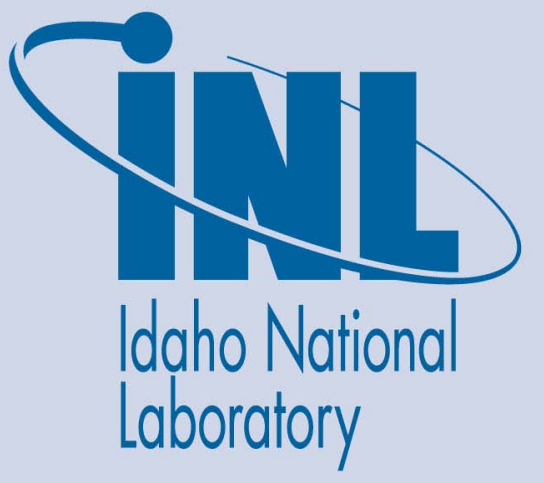

The INL is a U.S. Department of Energy National Laboratory operated by Battelle Energy Alliance 
INL/EXT-06-11601

Rev. 1

\title{
Low-Level Waste Disposal Alternatives Analysis Report
}

\author{
Timothy Carlson ${ }^{1}$ \\ Roy Grant ${ }^{1}$ \\ Joan Connolly 2 \\ Peggy Hinman ${ }^{2}$ \\ Charles Marcinkiewicz ${ }^{2}$
}

${ }^{1}$ Idaho National Laboratory

${ }^{2}$ North Wind, Inc.

September 2006

Idaho National Laboratory

Idaho Falls, Idaho 83415

Prepared for the

U.S. Department of Energy

Office of Nuclear Energy

Under DOE Idaho Operations Office

Contract DE-AC07-05ID14517 


\begin{abstract}
This report identifies and compares on-site and off-site disposal options for the disposal of contact-handled and remote-handled low-level waste generated by the Idaho National Laboratory and its tenants. Potential disposal options are screened for viability by waste type resulting in a short list of options for further consideration. The most credible options are selected after a systematic consideration of cost, schedule constraints, and risk.

In order to holistically address the approach for low-level waste disposal, options are compiled into comprehensive disposal schemes, that is, alternative scenarios. Each alternative scenario addresses the disposal path for all low-level waste types over the period of interest. The alternative scenarios are compared and ranked using cost, risk and complexity to arrive at the recommended approach. Schedule alignment with disposal needs is addressed to ensure that all waste types are managed appropriately.
\end{abstract}

The recommended alternative scenario for the disposal of low-level waste based on this analysis is to build a disposal facility at the Idaho National Laboratory Site. 


\section{EXECUTIVE SUMMARY}

This report addresses low-level radioactive waste (LLW) that is currently generated and disposed at the Idaho National Laboratory (INL). Battelle Energy Alliance (BEA) manages the INL Site for the U.S. Department of Energy (DOE). The bulk of the INL Site's LLW is currently disposed at the Subsurface Disposal Area (SDA) located at the Radioactive Waste Management Complex (RWMC). BEA's contract includes responsibility to develop a detailed plan that describes the steps necessary for ensuring disposal capability will be available for contact-handled $(\mathrm{CH})$ and remote-handled (RH) low-level waste (LLW) upon closure of the RWMC. The RWMC is being closed as part of cleanup activities at the INL Site. BEA's contract directs it to implement alternatives to use of the SDA for disposal of CH LLW by the end of Fiscal Year (FY) 2008 and for disposal of RH LLW by the end of FY 2009.

This report presents an analysis of options for disposal of CH and RH LLW generated by the INL and its tenants, specifically Advanced Mixed Waste Treatment Project (AMWTP), the Idaho Cleanup Project (ICP), as well as the Naval Reactors Facility (NRF). While the bulk of the CH LLW can be disposed off-site, RH LLW, particularly activated metals, have certain radionuclides and high radiation levels that result in increased costs and risks for off-site transportation and disposal.

This report first discusses the options for off-site disposal of CH LLW and RH LLW. For on-site disposal options, the schedule and costs for a new facility are presented for both CH and RH LLW. The various options for disposal of each waste stream are combined into credible alternative scenarios and described in Section 5. This section forms the basis for the recommended alternative scenario that achieves disposal of all of the INL Site's predicted LLW to be generated through 2035, when the INL Site is to complete its cleanup mission under a settlement agreement with the State of Idaho.

The alternative scenarios are presented in the report:

- $\quad$ Alternative Scenario 1-All LLW disposed on-site in a new facility

- $\quad$ Alternative Scenario 2-All LLW disposed off-site at the Nevada Test Site (NTS)

- $\quad$ Alternative Scenario 3-CH LLW, RH LLW debris, and RH LLW resins disposed off-site at NTS; RH LLW activated metals disposed off-site at Hanford

- $\quad$ Alternative Scenario 4-CH LLW, RH LLW debris, and RH LLW resins disposed off-site at NTS; RH LLW activated metals disposed on-site.

These alternative scenarios are assessed for cost, risk, and complexity. The recommended alternative scenario is disposal of all LLW on-site. This alternative scenario has the lowest cost and involves the least amount of up front investment. It is the lowest risk because it presents no off-site transportation or disposal considerations. It is also the least complex because just one facility is required to accomplish disposal of all LLW.

The approach in this report is to identify disposal alternatives to use of the SDA; however, due to the challenges involved in securing an alternative for RH LLW disposal by FY 2010, the continued use of the SDA is carried forward in the analysis past the end of FY 2009, where appropriate. Additional vaults were installed in the SDA between 2001 and 2003. These vaults are forecasted to have disposal capacity through FY 2015. 


\section{CONTENTS}

ABSTRACT

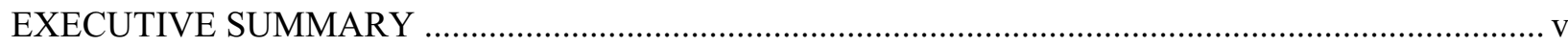

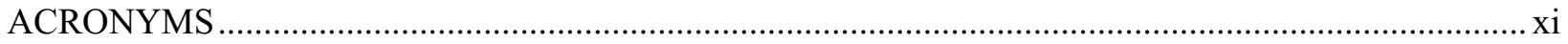

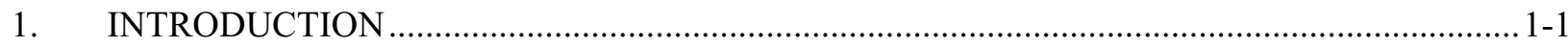

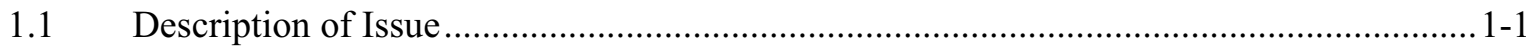

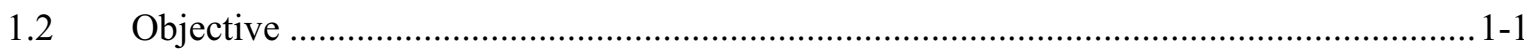

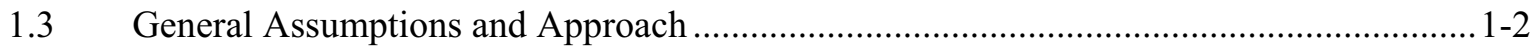

1.4 Alternative Scenarios and Criteria for Identifying Recommended Disposal Strategy ...... 1-6

2. IDAHO NATIONAL LABORATORY LOW-LEVEL WASTE STREAMS …............................2-1

2.1 Contact-Handled Low-Level Waste Types and Volume Expected Through 2035 ...........2-1

2.1.1 CH LLW Generation Rates .................................................................

2.1.2 General Characteristics of CH LLW Packaging ............................................2-1

2.2 Remote-Handled Low-Level Waste Types and Volume Expected through 2035.............2-3

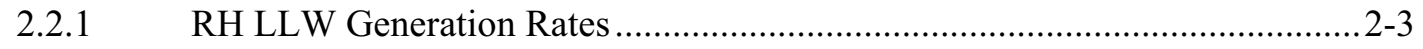

2.2.2 General Characteristics of RH LLW Packaging ......................................... 2-5

3. OFF-SITE OPTIONS FOR LOW-LEVEL WASTE DISPOSAL .............................................

3.1 Selection of Off-Site Facilities for Evaluation ........................................................... 3-1

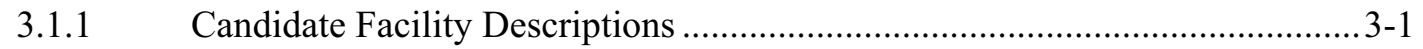

3.1.2 Candidate Facility Screening …….............................................................. 3-3

3.2 Screening Analysis for Off-Site Disposal of Contact-Handled Low-Level Waste ........... 3-6

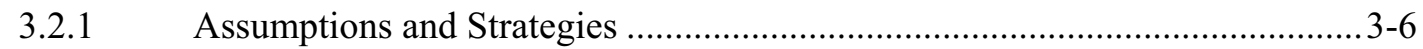

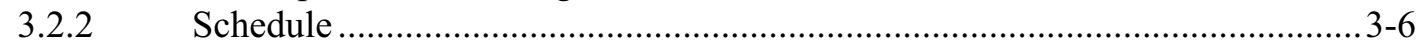

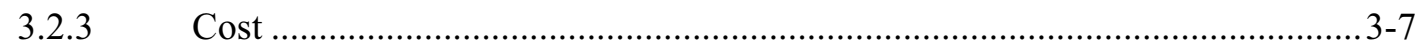

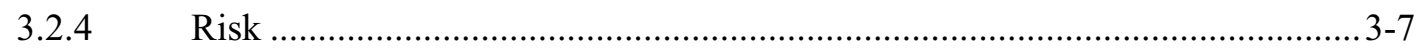

3.3 Screening Analysis for Off-Site Disposal of Remote-Handled Low-Level

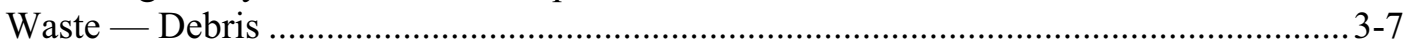

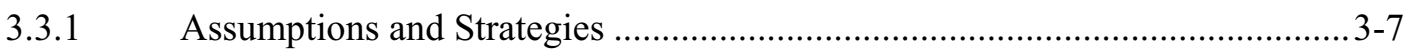

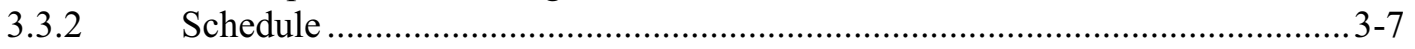

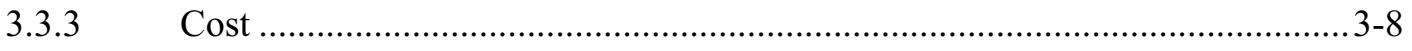

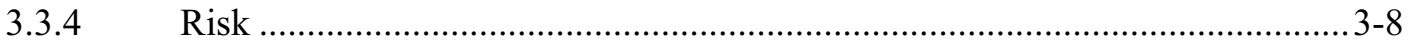


3.4 Screening Analysis for Off-Site Disposal of Remote-Handled Low-Level

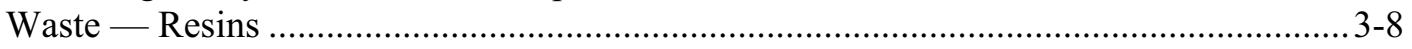

3.4.1 Assumptions and Strategies ..................................................................

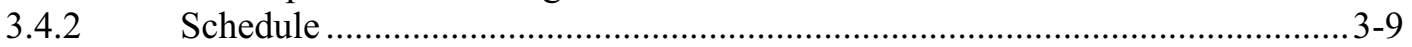

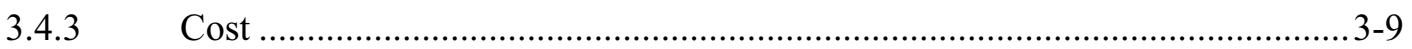

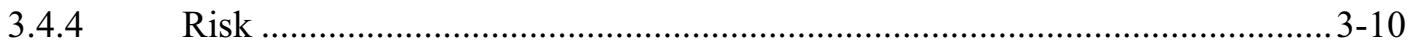

3.5 Screening Analysis for Off-Site Disposal of Remote-Handled Low-Level Waste -

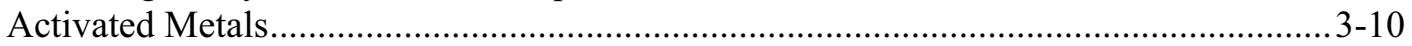

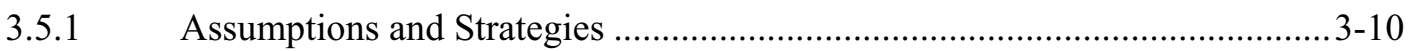

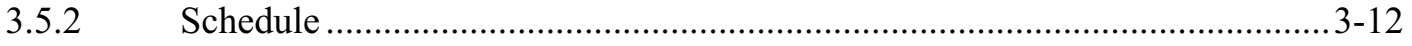

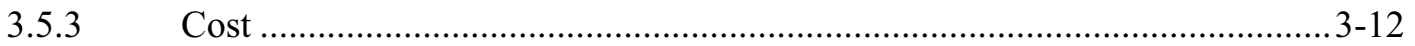

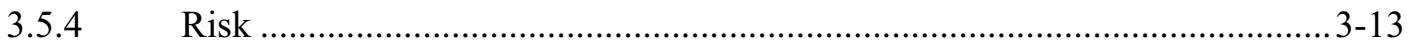

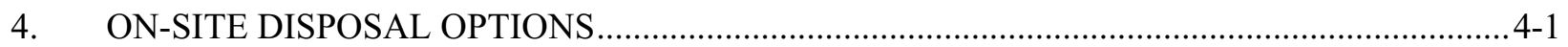

4.1 Siting and Design Considerations for On-Site Disposal of Idaho National

Laboratory Low-Level Waste...................................................................................... 4-1

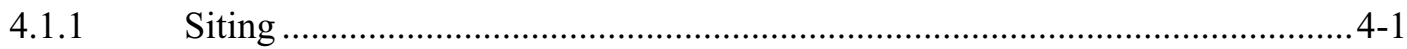

4.1.2 Disposal Facility Description/WAC ......................................................... 4-2

4.2 Analysis of On-Site Disposal of All Low-Level Waste ..................................................4-4

4.2.1 Assumptions and Strategies .................................................................. 4 -4

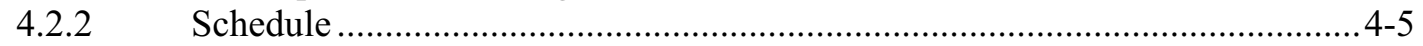

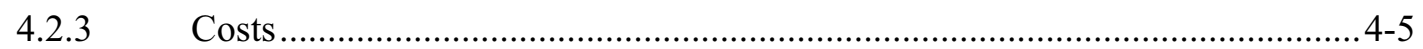

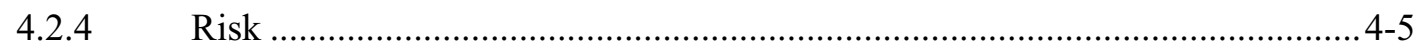

4.3 Screening Analysis for On-Site Disposal of Remote-Handled Low-Level Waste -

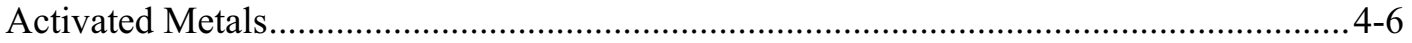

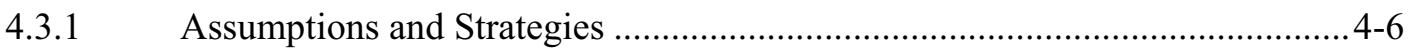

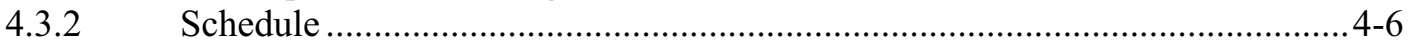

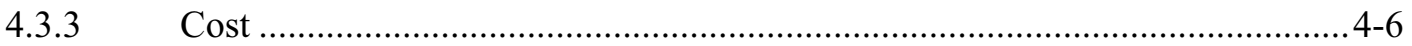

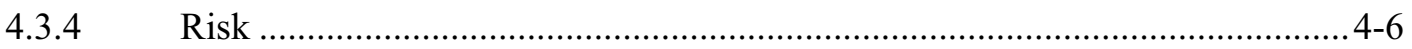

5. LOW-LEVEL WASTE DISPOSAL Alternative SCENARIO IDENTIFICATION AND

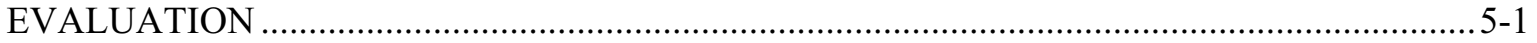

5.1 Alternative Scenario 1: Disposal of All Low-Level Waste On-Site................................ 5-1

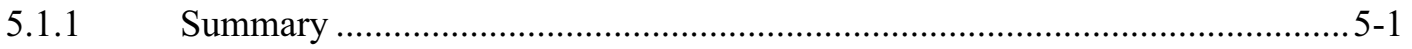

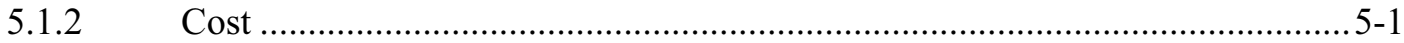

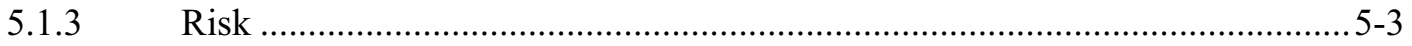

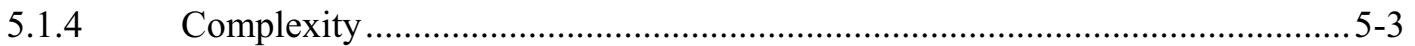


5.2 Alternative Scenario 2: Disposal of all Low-Level Waste Off-Site at

Nevada Test Site.

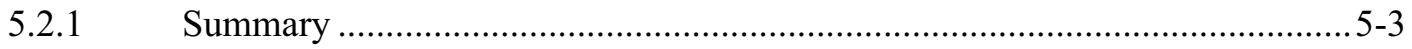

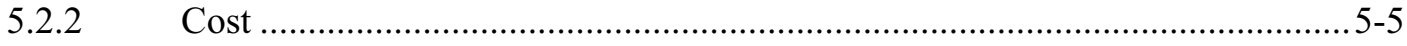

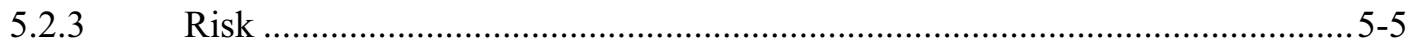

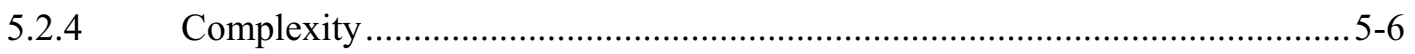

5.3 Alternative Scenario 3: Disposal of Contact-Handled Low-Level Waste,

Remote-Handled Debris, and Remote-Handled Resins at Nevada Test Site;

Disposal of Remote-Handled Activated Metals at Hanford ............................................. 5-6

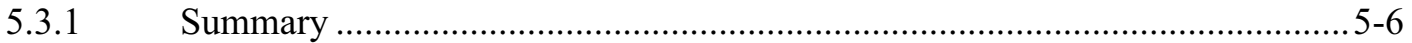

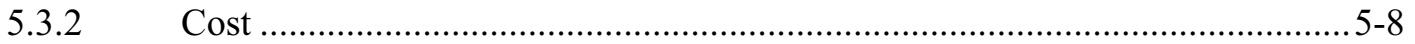

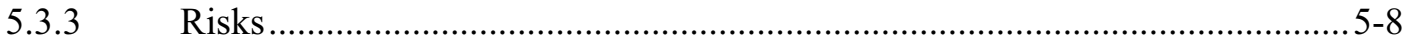

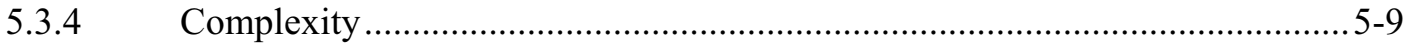

5.4 Alternative Scenario 4: Shipment of Contact-Handled Low-Level Waste, RemoteHandled Resins, and Remote-Handled Debris to Nevada Test Site; Disposal of Remote-Handled Activated Metals On-Site ........................................................................... 5-9

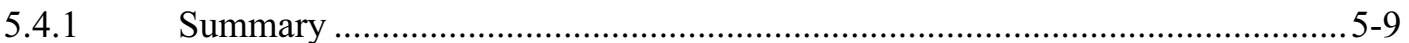

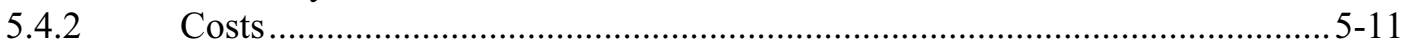

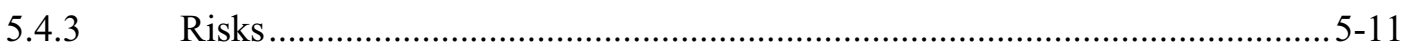

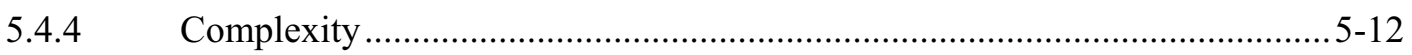

5.5 Evaluation of Alternative Scenarios ........................................................................... 5-12

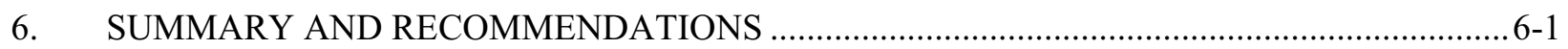

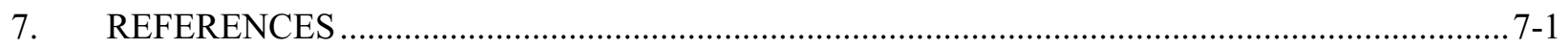

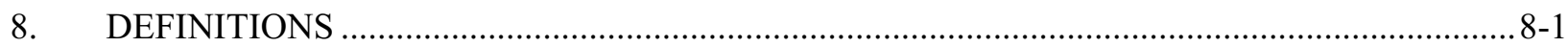

\section{APPENDIXES}

Appendix A —LLW Disposal Alternatives Task Force ….................................................................. A-1

Appendix B —LLW Disposal Facility Screening Analysis ............................................................ B-1

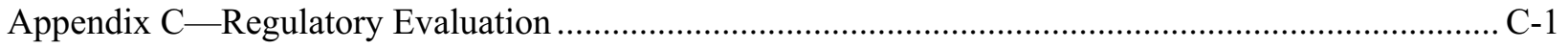

Appendix D —LLW Disposal Alternative Scenarios — Assumptions, Schedules, Costs ....................... D-1

Appendix E—Cask Availability Assessment ……......................................................................... E-1 


\section{FIGURES}

1-1. Low-level waste disposal pathway analysis process ....

1-2. Pathways considered for disposal of contact-handled and remote-handled low-level waste from the Idaho National Laboratory....

2-1. Contact-handled low-level waste projections from actual waste generation history and the BLDD.

2-2. Remote-handled waste generation rate projections

3-1. Schedule for off-site disposal activities for remote-handled low-level waste debris

3-2. Schedule for off-site disposal activities for remote-handled low-level waste resins

3-3. Schedule for off-site disposal activities for remote-handled low-level waste activated metals using truck-loaded casks.

3-4. Schedule for off-site disposal activities for remote-handled low-level waste activated metals using rail-loaded casks

4-1. RH concrete vaults

4-2. Schedule for on-site disposal facility

5-1. Alternative Scenario 1 - Disposal of all low-level waste on-site

5-2. Alternative Scenario 2 - Disposal of all low-level waste off-site - Nevada Test Site

5-3. Alternative Scenario 3 - Disposal of all low-level waste off-site - Nevada Test Site/Hanford

5-4. Alternative Scenario 4 - Disposal of low-level waste off-site to Nevada Test Site (debris and resins) and on-site (metals)....

6-1. Annual project costs by disposal alternative scenario

\section{TABLES}

1-1. Options considered for low-level waste disposal

2-1. Average waste generation by Idaho National Laboratory generator

2-2. Remote-handled low-level waste debris, resins, and activated metals waste streams

2-3. Waste anticipated to be generated for each remote-handled low-level waste at the Idaho National Laboratory Site......

3-1. Disposal facility screening: Waste Acceptance Criteria compliance and availability relative to low-level waste types

5-4. Alternative scenario rankings for cost, risk, and complexity 


\section{ACRONYMS}

AMWTP Advanced Mixed Waste Treatment Project

ATR

Advanced Test Reactor

BEA

Battelle Energy Alliance

BLDD baseline mixed and low-level waste data disposition

CD

Critical Decision

CDRL

contract data requirements list

CERCLA Comprehensive Environmental Response, Compensation and Liability Act

CFR Code of Federal Regulations

$\mathrm{CH} \quad$ contact-handled

CIC core internals changeout

D\&D decontamination and decommissioning

DOE U.S. Department of Energy

DOT U.S. Department of Transportation

EA environmental assessment

EIS environmental impact statement

EM Environmental Management

EMWMF Environmental Management Waste Management Facility

FONSI finding of no significant impact

FY fiscal year

ICDF Idaho CERCLA Disposal Facility

ICP Idaho Cleanup Project

INL Idaho National Laboratory

LLBG Low-Level Waste Burial Grounds

LLW low-level waste

LSA low specific activity 


\begin{tabular}{|c|c|}
\hline MFC & Materials and Fuels Complex \\
\hline NEPA & National Environmental Policy Act \\
\hline NNSA & National Nuclear Security Administration \\
\hline NRC & Nuclear Regulatory Commission \\
\hline NRF & Naval Reactors Facility \\
\hline NTS & Nevada Test Site \\
\hline $\mathrm{NuPac}$ & Nuclear Packaging \\
\hline RCRA & Resource Conservation and Recovery Act \\
\hline RH & remote-handled \\
\hline ROD & Record of Decision \\
\hline RTC & Reactor Technology Complex \\
\hline RTP & Remote Treatment Project \\
\hline RWMC & Radioactive Waste Management Complex \\
\hline SDA & Subsurface Disposal Area \\
\hline SNM & Special Nuclear Material \\
\hline SRS & Savannah River Site \\
\hline TRU & transuranic \\
\hline TSA-RE & Transuranic Storage Area - Retrieval Enclosure \\
\hline WAC & Waste Acceptance Criteria \\
\hline WCF & waste calciner filter \\
\hline WCS & Waste Control Specialists \\
\hline WIPP & Waste Isolation Pilot Plant \\
\hline
\end{tabular}




\section{Low-Level Waste Disposal Alternatives Report}

\section{INTRODUCTION}

This report presents an analysis of options for disposal of contact-handled $(\mathrm{CH})$ and remote-handled (RH) low-level waste (LLW) generated by the Idaho National Laboratory (INL) and its tenants, specifically the Advanced Mixed Waste Treatment Project (AMWTP), the Idaho Cleanup Project (ICP), as well as the Naval Reactors Facility (NRF). The contents of this report will support decision-making and planning activities for future LLW waste disposal. A systematic approach has been used to identify disposal needs, options for meeting those needs, and to develop the associated costs, schedules, and risks in sufficient detail to a make valid comparison of the options.

\subsection{Description of Issue}

Battelle Energy Alliance (BEA) manages the INL Site for the U.S. Department of Energy (DOE). BEA's contract requires it to "attain [an] alternate disposal capacity (off-site) and have this disposal capacity on-line by October 1, 2008 for contact-handled LLW, and by October 1, 2009 for remote-handled LLW. The new disposal capacity shall include any required supporting transportation system needed to accommodate both INL and, if necessary, other tenant (e.g., NRF) remote-handled LLW" (INL 2004). In addition, the contract data requirements list (CDRL), Item No. I.38, requires the development of a "detailed plan that describes the steps necessary for ensuring disposal capability will be available for contact-handled and remote-handled LLW, upon closure of the Radioactive Waste Management Complex" (DOE 2006). Per CDRL I.38, the plan needs to describe the involvement of INL Site tenants; the approach to develop both on-site and off-site disposal options; total capital and operating funding requirements by year; the overall schedule; and a recommended preferred alternative.

The INL Site routinely generates CH LLW from facility operations and decontamination and decommissioning (D\&D) of inactive facilities. CH LLW and a large portion of the RH LLW generated at the INL Site meets the Waste Acceptance Criteria (WAC) for off-site disposal sites and can be shipped using existing commercial containers. However, due to the presence of certain radionuclides and high radiations levels, RH LLW activated metals present unique challenges if shipping off-site, both in terms of packaging and shipping and acceptance by off-site disposal sites. Currently, only the Nevada Test Site (NTS) is open to off-site waste that can potentially accept all of this waste. Consequently, the challenge of this analysis is to identify a viable, cost-effective LLW disposal alternative that will minimize the impact to INL Site operations and future missions.

\subsection{Objective}

The objective of this report is to provide recommendations on preferred alternative scenarios for future LLW disposal. A systematic approach was employed to achieve this objective, which involved defining future LLW disposal needs, evaluating options and disposal alternative scenarios for LLW, and recommending an alternative.

In order to meet this objective, BEA and the other tenants of the INL Site worked as a task force to ensure that a complete range of disposal needs were considered. Appendix A lists the task force members and organizations. 
The DOE Manual for implementing DOE Order 435.1 provides DOE's policy for disposing of radioactive waste, including LLW:

\begin{abstract}
$D O E$ radioactive waste shall be treated, stored, and in the case of low-level waste, disposed of at the site where the waste is generated, if practical; or at another DOE facility. If DOE capabilities are not practical or cost effective, exemptions may be approved to allow use of non-DOE facilities for the storage, treatment, or disposal of DOE radioactive waste.
\end{abstract}

This plan includes the analysis that is needed to implement DOE policy. It addresses CH LLW disposal needs after October 1, 2008, and RH LLW disposal needs after October 1, 2009. It does not include mixed low-level waste, which DOE has determined will not be disposed on-site (DOE 2000). The LLW identified for planning purposes includes waste expected to be generated from ongoing operations and facility closures, in addition to a contingency to account for future missions through 2035. The report first discusses the options for off-site disposal of CH LLW and RH LLW. For on-site disposal options, the schedule and costs for a new facility are presented for both $\mathrm{CH}$ and $\mathrm{RH}$ LLW. The likelihood that a facility could be located on the INL Site is addressed.

Following the evaluation of options, the report discusses possible alternative scenarios in which various options can be combined and presents recommendations.

\title{
1.3 General Assumptions and Approach
}

A systematic approach was used to assess LLW management and accomplish the objectives for this report. The wastes expected to be generated were inventoried, categorized, and evaluated against the WAC of existing off-site DOE and commercial disposal facilities. Viable facilities were identified, including a new on-site facility. For these facilities, shipping, packaging, and infrastructure needs were evaluated in order to identify schedules, costs, and risk. The options for the various waste types were then grouped into alternative scenarios that represent pathways to accomplish disposition of all INL Site CH and RH LLW through 2035. These alternative scenarios were evaluated and ranked based upon cost, risk, and complexity discriminators. This ranking forms the basis for recommendations and identification of critical next steps required to pursue the recommendations. Figure 1-1 depicts the process that was utilized to develop the alternative scenarios described for off-site disposal. Appendix B documents in detail the process and rationale that was used to screen the options ultimately selected for review in this report.

The options in this report are presented by waste type within the off-site and on-site categories. Off-site options for CH LLW and the three types of RH LLW are evaluated in Section 3. RH LLW is divided into RH debris, $\mathrm{RH}$ resins, and $\mathrm{RH}$ activated metal waste streams that were analyzed separately because each presents unique disposal considerations, translating into differing schedule and option considerations. On-site disposal options utilizing engineered design features for CH LLW and the three types of RH LLW are evaluated in Section 4. Figure 1-2 is a schematic of all of the options and the alternative scenarios assessed relative to the time frames for implementation. The purpose of Figure 1-2 is to provide the reader with insight into all the options investigated in this report. The graphic is repeated in Section 5 where finite disposal paths are described with those options that do not apply faded out. Table 1-1 summarizes the options evaluated in Sections 3 and 4. 


\section{Low-Level Waste Disposal Pathway Analysis Process}

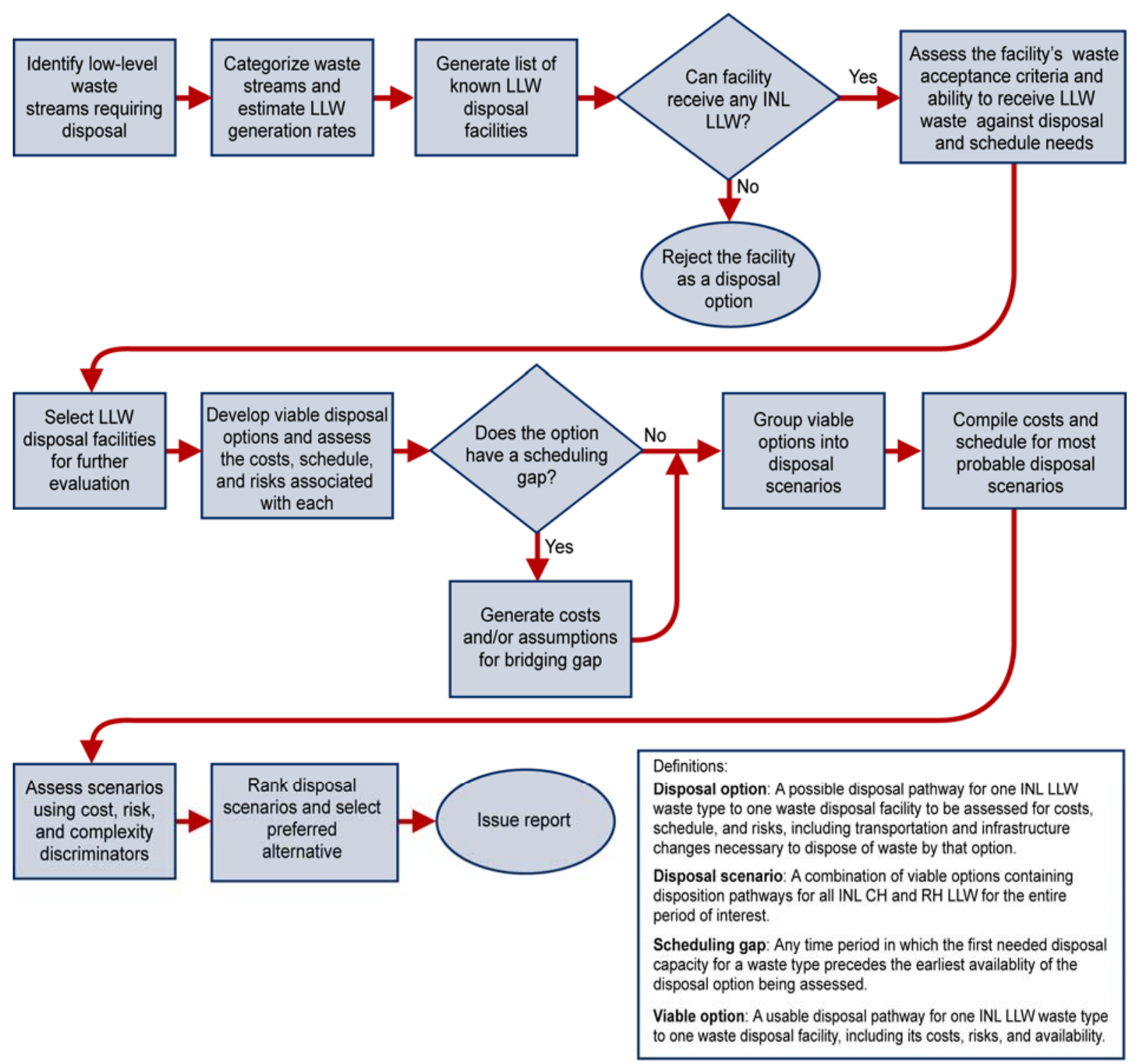

Figure 1-1. Low-level waste disposal pathway analysis process. 


\section{CH LLW Disposal Options}

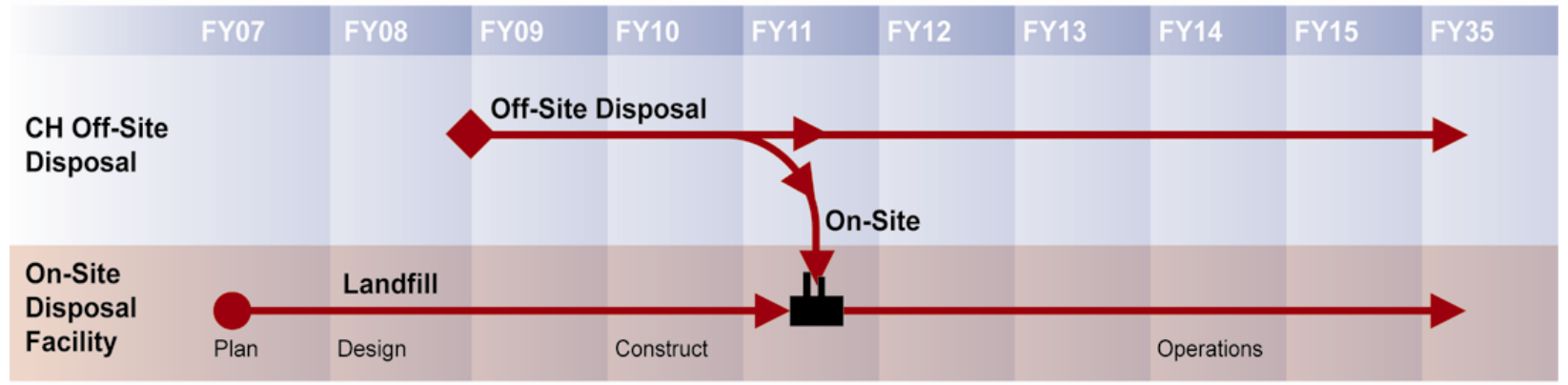

\section{RH LLW Disposal Options}

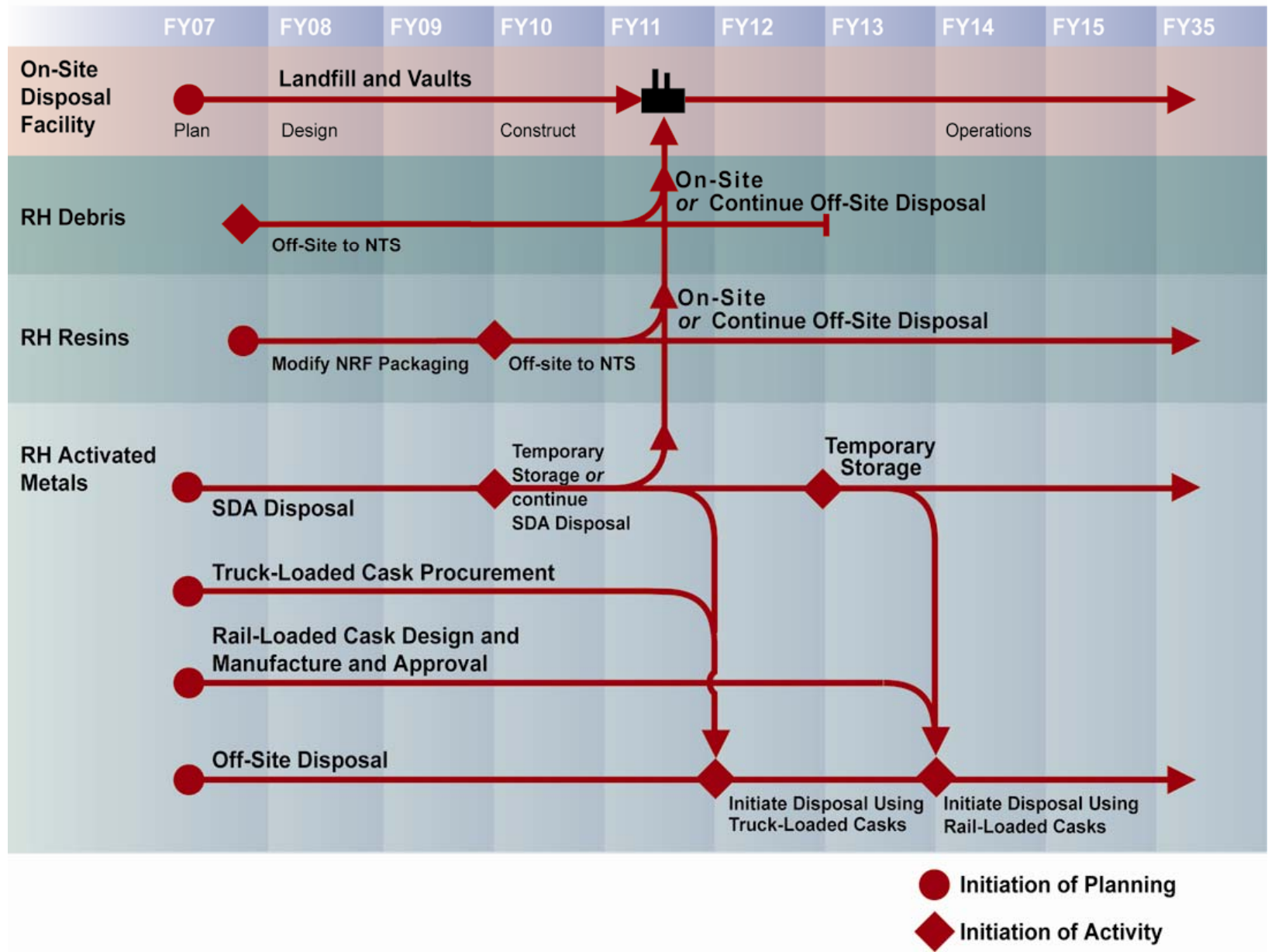

Figure 1-2. Pathways considered for disposal of contact-handled and remote-handled low-level waste from the Idaho National Laboratory. 
Table 1-1. Options considered for low-level waste disposal.

\begin{tabular}{ll}
\hline \multicolumn{1}{c}{ Options } & Waste Stream \\
\hline Off-site disposal at: & \\
Barnwell, South Carolina & \\
Waste Control Specialists, Texas & CH LLW \\
Oak Ridge, Tennessee & RH LLW Debris \\
Nevada Test Site, Nevada & RH LLW Resins \\
Hanford, Washington & RH LLW Activated Metals \\
EnergySolutions, Utah & \\
U.S. Ecology, Washington & \\
Savannah River Site, South Carolina & \\
On-site disposal at: & \\
New Facility & \\
\hline
\end{tabular}

Uncertainties in schedules, volumes of waste streams, changing missions, and other unforeseeable circumstances required that a number of assumptions be developed in order to conduct a comprehensive analysis. Assumptions that are specific to a particular disposal alternative are included in those sections of the report where that alternative is presented. The following assumptions provide the general framework by which the report was developed:

- $\quad$ Cost estimates used as the basis of this analysis are rough order of magnitude estimates.

- $\quad$ Operating dollars will be available in fiscal year (FY) 2007 for purposes of initiating activities and funding must also be available in the out years to support the alternative scenarios analyzed. Inadequate funding at any point would impact cost and schedule, and could negate assumptions critical to the viability of the alternative scenario. Specifically, if FY 2007 funding is not available, impact to the proposed schedule could require continued use of the Subsurface Disposal Area (SDA) for disposal of NRF RH activated metals and/or development of interim storage for this waste stream at an on-site facility.

- $\quad$ Project costs are presented by year through FY 2035 for purposes of developing estimates and comparisons of alternatives. FY 2035 was selected as an end date to coincide with DOE commitments for cleanup and movement of spent nuclear fuel.

- Contingencies ranging from 20 to $60 \%$ are added to activities or equipment costs to account for future uncertainties.

- $\quad$ Except where specifically noted, the disposal facilities discussed in this plan are assumed to be available through 2035 despite uncertainties associated with LLW disposal capacity, political constraints, and licensing.

- $\quad$ Some packages within individual waste streams may not meet the criteria for the disposal paths described in the report once full characterization occurs. However, for the purposes of this report, schedule and cost estimates assume the projected waste volumes will be dispositioned. 
- Potential impacts on human health and the environment for disposal of INL Site LLW have been assessed under National Environmental Policy Act (NEPA) Environmental Impact Statements (EISs) (DOE 2000), and that documentation provides sufficient basis to implement all of the disposal options addressed in this report. If on-site disposal is selected, plans for a new facility will be subject to further review under NEPA (42 USC § 4321) in the form of an Environmental Assessment (EA).

- $\quad$ Temporary storage at the generating facility is available at NRF for up to 2 years after disposal is scheduled to cease at the SDA and available at Advanced Test Reactor (ATR) until FY 2014 if needed. Temporary storage will be located at the Materials and Fuels Complex (MFC) for activated metal waste expected to be generated beginning FY 2012.

\subsection{Alternative Scenarios and Criteria for Identifying Recommended Disposal Strategy}

Four alternative scenarios that represent a combination of the disposal options and provide a recommended course of action are discussed in Section 6 The alternative scenarios contain a range of options from disposal of all LLW off-site to disposal of all LLW on-site. Combinations of options for the RH LLW waste types are also presented. The alternative scenarios are:

- $\quad$ Alternative Scenario 1-All LLW disposed on-site in a new facility

- $\quad$ Alternative Scenario 2-All LLW disposed off-site at NTS

- $\quad$ Alternative Scenario 3-CH LLW, RH LLW debris, and RH LLW resins disposed off-site at NTS; RH LLW activated metals disposed off-site at Hanford

- $\quad$ Alternative Scenario 4-CH LLW, RH LLW debris, and RH LLW resins disposed off-site at NTS; RH LLW activated metals disposed on-site.

The alternative scenarios are ranked according to cost, risk, and complexity of implementation, and then a recommended alternative scenario is presented. Costs are presented for ranking as net present value costs based on total project costs for the alternative scenarios. Risks for successful implementation of the alternative scenarios are presented to address potential impacts related to technical, cost, schedule, programmatic, and political considerations. Complexity is discussed in terms of the number of activities involved to achieve the alternative scenario and the location and number of disposal facilities involved. 


\section{IDAHO NATIONAL LABORATORY LOW-LEVEL WASTE STREAMS}

This section presents a description of the INL Site CH LLW and RH LLW that will be generated and require disposal between 2008 and 2035.

\subsection{Contact-Handled Low-Level Waste Types and Volume Expected Through 2035}

Definitions used to distinguish $\mathrm{CH}$ from RH waste vary among DOE facilities and between DOE and commercial LLW disposal facilities. For example, the NTS WAC (DOE-NV 2006) stipulates that waste packages that exceed $100 \mathrm{mrem} / \mathrm{hr}$ at $30 \mathrm{~cm}$ shall be considered for remote handling, while the SDA uses $500 \mathrm{mrem} / \mathrm{hr}$ to distinguish between CH and RH LLW (DOE-ID 2001). Because this report addresses potential disposal options at off-site LLW disposal facilities, for consistency we will define CH LLW as waste having a dose equivalent of less than $200 \mathrm{mrem} / \mathrm{hr}$ at contact. This corresponds to the U.S. Department of Transportation (DOT) limit above which waste must be shipped in an exclusive use vehicle (49 CFR 173.441). The INL Site routinely generates CH LLW from facility operations and from the D\&D of inactive facilities. Most of the waste is debris such as personal protective equipment, wood, plastics, cloth, glass, ferrous and non-ferrous metals, concrete and piping generated from operations, maintenance, surveillance, and cleanup. Solidified/ stabilized liquids and sludge are also included. CH LLW comprises approximately $98 \%$ of the LLW generated at the INL Site.

Additional considerations for INL Site LLW generators are the nature of the missions being supported. Radioactive waste, to which access is controlled for national security reasons and which cannot be declassified, is managed in accordance with the requirements of DOE M 473.1-1 and, DOE O 474.1. Classified waste, waste containing accountable nuclear material, waste with fissile material, and waste containing special nuclear material (SNM) are managed on a case-by-case basis, and some waste streams require disposal at DOE operated facilities. As such, the INL will require waste disposal certification for at least one DOE operated LLW disposal facility.

\subsubsection{CH LLW Generation Rates}

The annual average generation rate for CH LLW is $4,000 \mathrm{~m}^{3}$, based upon current generation rates. Table 2-1 provides the break down of generation rates by tenant generator. The DOE Environmental Management (EM) baseline mixed and low-level waste data disposition call (BLDD) ${ }^{\mathrm{a}}$ projects a drop in this generation rate over time due to completion of closure activities. This is illustrated in Figure 2-1. However, new nuclear missions on the INL Site are not considered in this prediction nor are continuing clean-up missions beyond the current clean-up contract. Therefore, for purposes of this report, the current generation rate of $4,000 \mathrm{~m}^{3} /$ year will be used to project future waste generation volumes from 2008 through 2035 as a contingency for new missions. It is therefore estimated that disposal capacity for approximately $108,000 \mathrm{~m}^{3}$ of CH LLW will be needed. This should provide any additional capacity needed as a contingency for wastes generated by new missions.

\subsubsection{General Characteristics of CH LLW Packaging}

For on-site disposal, CH LLW is packaged in a wide variety of configurations. These include wooden boxes, metal bins, round and square drums, cask inserts, woven polypropylene bags, and other miscellaneous containers. Some large items are not packaged and are currently disposed of in a bulk pit area. For shipment off-site, the waste will have to be packaged in DOT-compliant packaging.

\footnotetext{
a Data submitted for DOE-EM baseline mixed and low-level waste data disposition call (BLDD), March 2006.
} 
Table 2-1. Average waste generation by Idaho National Laboratory generator.

CH LLW Generated Annually

Waste Generator

INL

ICP

NRF

AMWTP $^{\mathrm{a}}$ $\left(\mathrm{m}^{3} / \mathrm{yr}\right)$

900

1,120

1,044

936

Total

4,000

a. AMWTP will cease generation in FY 2012.

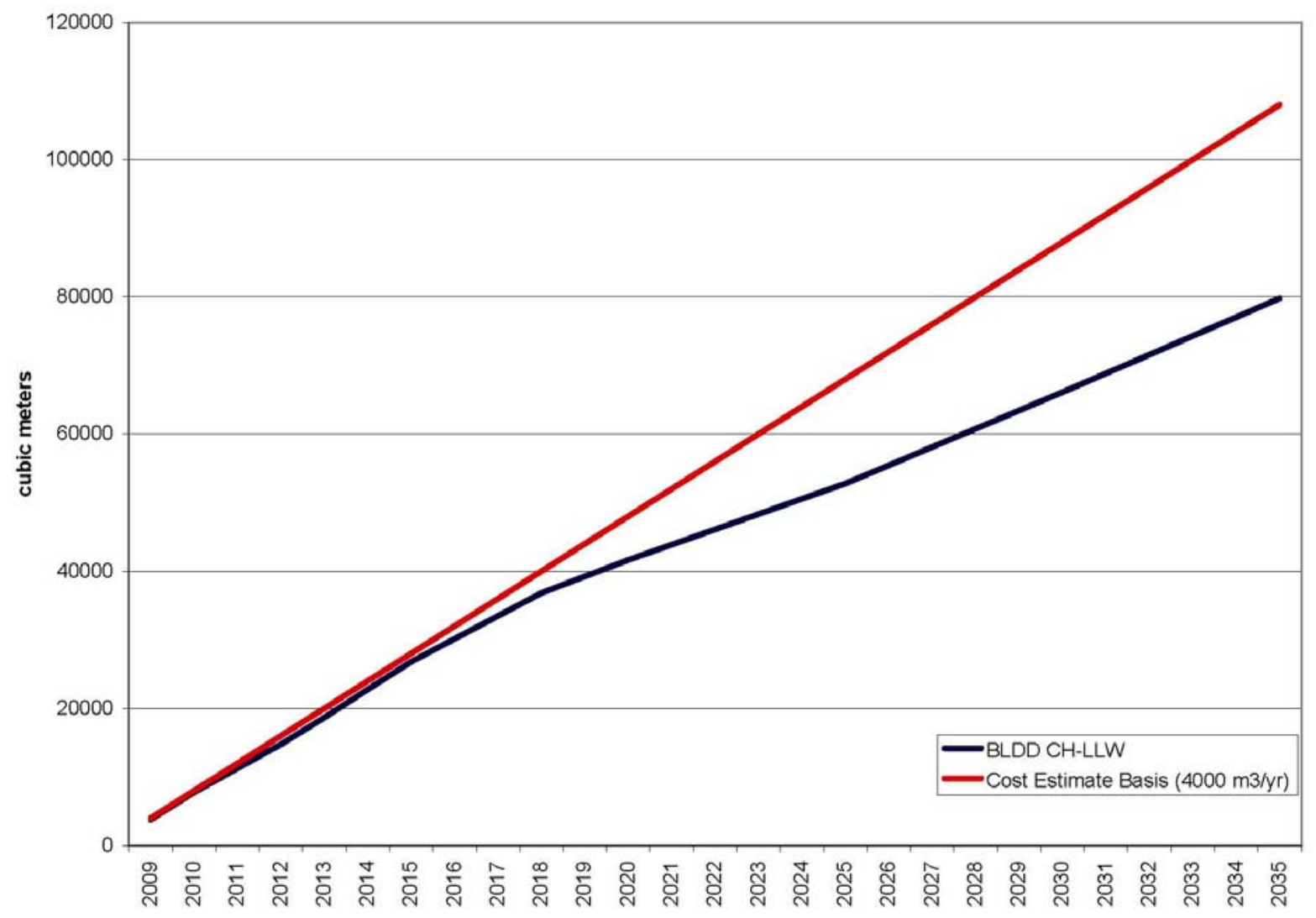

Figure 2-1. Contact-handled low-level waste projections from actual waste generation history and the BLDD. 


\subsection{Remote-Handled Low-Level Waste Types and Volume Expected through 2035}

This section describes the three major waste streams that comprise RH LLW. The discussion includes generation rates, total volumes, waste packaging, and radiological characteristics.

\subsubsection{RH LLW Generation Rates}

The INL Site produces three types of RH LLW:

- Debris

- Resins

- $\quad$ Activated metals.

Resin and activated metals waste streams are generated by multiple facilities; debris waste is generated exclusively at the AMWTP. Table 2-2 describes these waste streams by generator.

Table 2-2. Remote-handled low-level waste debris, resins, and activated metals waste streams.

\begin{tabular}{|c|c|c|}
\hline $\begin{array}{l}\text { Waste } \\
\text { Stream }\end{array}$ & Generator & Description \\
\hline Debris & AMWTP & $\begin{array}{l}\text { Floor sweepings, metallurgical mounts, wooly bags, powder in rags, } \\
\text { sludge/powder, rods, pellets and scraps from fabrication of nuclear } \\
\text { reactor fuel. It is currently in storage modules and in the Transuranic } \\
\text { Storage Area Retrieval Enclosure (TSA-RE) berm. Waste from the TSA- } \\
\text { RE will be retrieved during the AMWTP transuranic (TRU) waste } \\
\text { retrieval process through } 2012 \text {. Maximum contact dose is } 250 \mathrm{mrem} / \mathrm{hr} \text {. It } \\
\text { does not meet the current WAC for on-site disposal due to fissile content. } \\
\text { It is handled as RH LLW due to fissile content and dose rate exceeding } \\
\text { CH limits for similarly managed TRU waste. }\end{array}$ \\
\hline \multirow{2}{*}{ Resins } & $\begin{array}{l}\text { INL } \\
(\text { RTC) }\end{array}$ & $\begin{array}{l}\text { The ATR produces ion exchange resins from pool and reactor operations. } \\
\text { Currently, the waste is disposed in the RWMC pit in EPICORETM II } \\
\text { liners. }\end{array}$ \\
\hline & NRF & $\begin{array}{l}\text { The NRF produces ion exchange resins from pool operations. Currently, } \\
\text { the waste is disposed of in the RWMC vaults in liners transported using a } \\
55 \text {-ton cask. }\end{array}$ \\
\hline \multirow{3}{*}{$\begin{array}{l}\text { Activated } \\
\text { Metals }\end{array}$} & $\begin{array}{l}\text { INL } \\
(\text { RTC) }\end{array}$ & $\begin{array}{l}\text { The ATR produces activated metals during reactor core change-out } \\
\text { operations approximately every } 8 \text { years. These components require an } \\
\text { approximate } 8 \text {-year decay time and are in storage at RTC. Previous } \\
\text { disposal has been at the RWMC using a cask that is no longer in use. }\end{array}$ \\
\hline & NRF & $\begin{array}{l}\text { The NRF produces activated metals during routine operations. Currently, } \\
\text { the waste is disposed in the RWMC vaults in } 55 \text {-ton scrap cask liners. }\end{array}$ \\
\hline & $\begin{array}{l}\text { INL } \\
(\mathrm{MFC})\end{array}$ & $\begin{array}{l}\text { The MFC will generate activated metals during waste segregation } \\
\text { operations in the yet to be built Remote Treatment Project (RTP) facility. } \\
\text { The RTP facility is expected to be operational in } 2012 \text {. No specific cask } \\
\text { has been identified. }\end{array}$ \\
\hline
\end{tabular}


The volumes and activity of RH LLW anticipated to be generated through 2035 have been forecast. The volumes are relatively small in comparison to the amount of CH LLW that will be generated over the same time periods. Off-site disposal of the RH LLW debris is planned to be complete by 2012. Of the remaining RH LLW, a significant portion is expected to be generated annually through 2035 . Table 2-3 provides rates of waste generation by location.

Table 2-3. Waste anticipated to be generated for each remote-handled low-level waste at the Idaho National Laboratory Site.

\begin{tabular}{|c|c|c|c|c|c|c|c|}
\hline \multicolumn{8}{|c|}{ 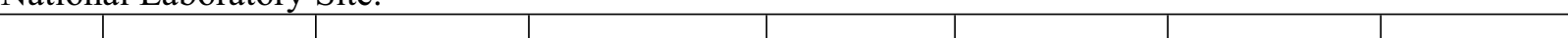 } \\
\hline 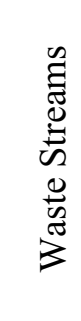 & 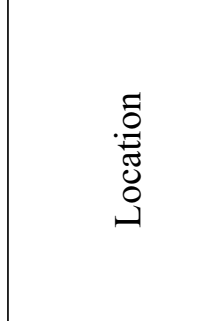 & 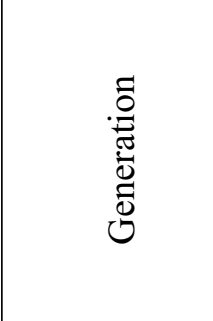 & $\begin{array}{l}\frac{\overrightarrow{0}}{0} \\
\frac{0}{0}\end{array}$ & 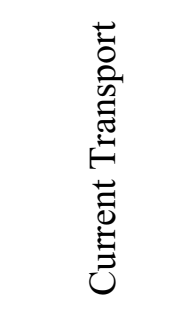 & 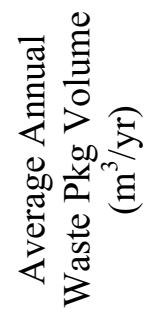 & 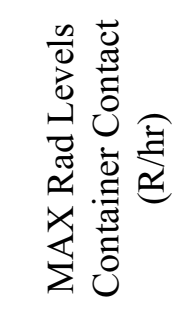 & 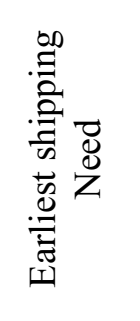 \\
\hline$\frac{n}{a}$ & AMWTP & Continuous & $\begin{array}{c}\text { Yearly } \\
(2007-2012)\end{array}$ & $\begin{array}{l}\text { Drums } \\
55 \text { gal } \\
\text { and } \\
110 \text { gal }\end{array}$ & 23 & $0.25^{\mathrm{a}}$ & 2007 \\
\hline \multirow{2}{*}{$\stackrel{\mathscr{E}}{\stackrel{0}{0}}$} & RTC & Continuous & $\begin{array}{l}\text { Yearly } \\
(2035)\end{array}$ & $\begin{array}{c}\text { NuPac } \\
\text { 14-210L } \\
\text { (shielding } \\
\text { only) }\end{array}$ & 36 & $2^{b}$ & 2010 \\
\hline & $\mathrm{NRF}$ & Continuous & $\begin{array}{l}\text { Yearly } \\
(2035)\end{array}$ & $\begin{array}{c}\text { 55-ton } \\
\text { Cask } \\
\text { (shielding } \\
\text { only) }\end{array}$ & 8 & 2 & 2010 \\
\hline \multirow{3}{*}{ 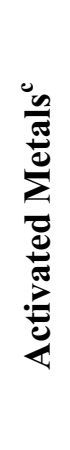 } & RTC & $\begin{array}{l}\text { Batch } \\
\text { (CIC) }\end{array}$ & $\begin{array}{c}\sim \text { Every } 8 \text { yr } \\
(2035)\end{array}$ & $\begin{array}{c}\text { None } \\
\text { Identified }\end{array}$ & 3 & 30,000 & 2014 \\
\hline & $\mathrm{NRF}$ & Continuous & $\begin{array}{l}\text { Yearly } \\
(2035)\end{array}$ & $\begin{array}{l}\text { 55-ton } \\
\text { Cask }\end{array}$ & 35 & 26,900 & 2010 \\
\hline & MFC & Continuous & $\begin{array}{c}\text { Yearly } \\
(2012-2035)\end{array}$ & $\begin{array}{c}\text { None } \\
\text { Identified }\end{array}$ & 6 & 30,000 & 2012 \\
\hline \multicolumn{8}{|c|}{$\begin{array}{l}\text { The value of } 0.25 \mathrm{R} / \mathrm{hr} \text { is applicable to the external transfer package. The contained waste has a maximum dose of } 2 \mathrm{R} / \mathrm{hr} \text {. } \\
\text { This dose rate clearly qualifies this waste as RH and it is included in the RH inventory. However, the practice at the SDA } \\
\text { has been to dispose of this waste in the pit and not in vaults. If the pits close in October } 2008 \text {, the RTC RH LLW resins } \\
\text { will be accommodated by generator storage or off-site shipment until the October } 2009 \text { deadline for provision of RH } \\
\text { LLW disposal capacity by INL. } \\
\text { Future projections are that on contact dose rates will be }<15,000 \mathrm{R} / \mathrm{hr} \text {. }\end{array}$} \\
\hline
\end{tabular}


The approach to estimating future volumes of RH LLW is the same as for CH LLW. The forecasted data, prepared in accordance with DOE's direction for DOE EM BLDD, projects a drop in this generation rate over time due to completion of closure activities. Use of the current generation rates will be used to project future waste generation volumes through 2035. According to the data in Table 2-3, the average annual generation rate for RH LLW, after 2012, is $83 \mathrm{~m}^{3} / \mathrm{yr}$. Current practice is that the Reactor Technology Complex (RTC) resins are disposed of in the pit area of the SDA and not in the vaults. Future practices at on-site facilities are assumed to use vault instead of pit disposal for all RH LLW. Figure 2-2 shows the relationship between waste projections used for cost estimates and the BLDD.

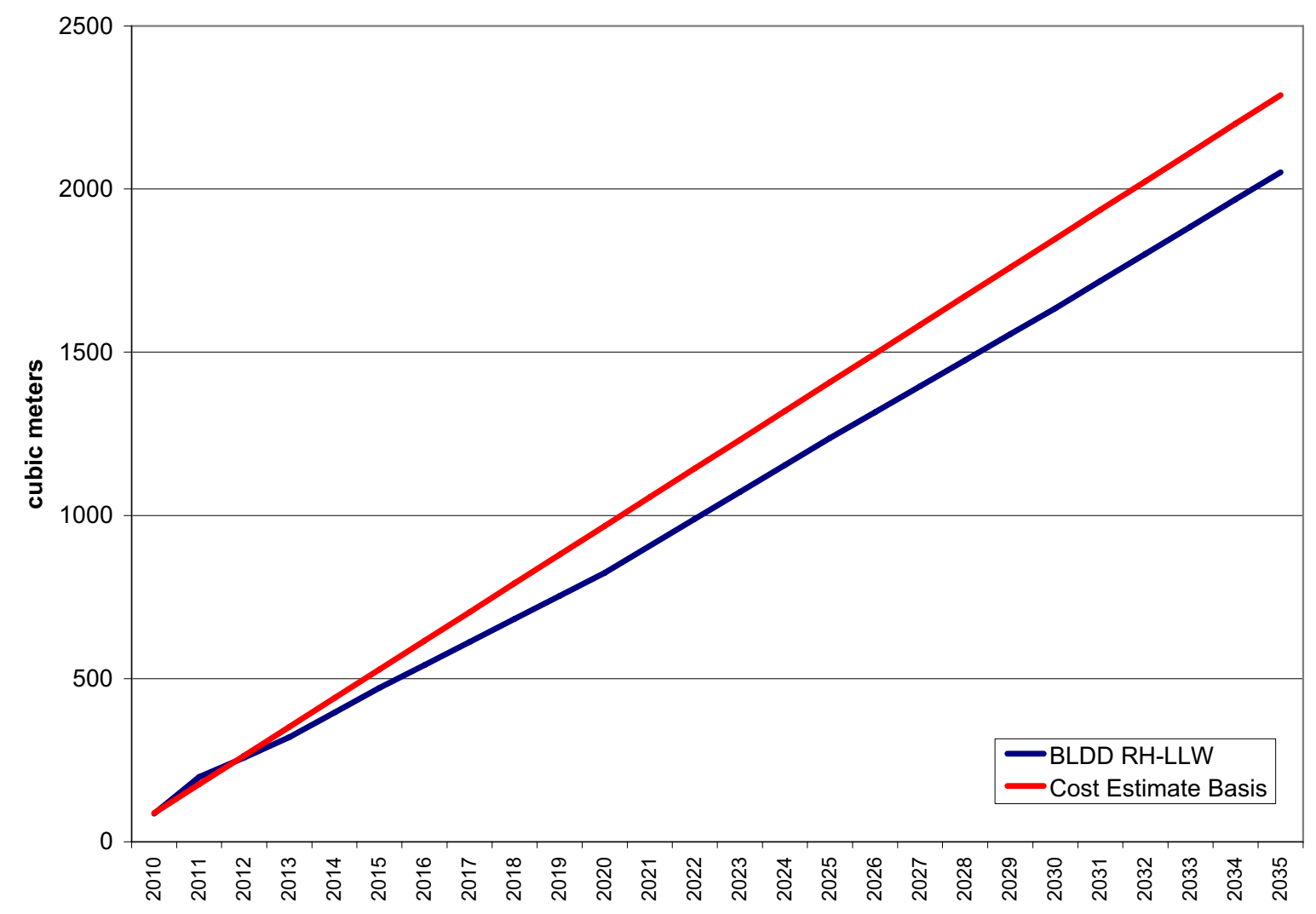

Figure 2-2. Remote-handled waste generation rate projections.

\subsubsection{General Characteristics of RH LLW Packaging}

The RH LLW debris is currently packaged in $6 \mathrm{M} / 2 \mathrm{R}$ containers that met Nuclear Regulatory Commission (NRC)/DOT standards at the time they were shipped to the RWMC in the 1970s and 1980s (see Appendix B). It is stored in shielded storage boxes in a storage module at the AMWTP. For shipment off-site, it will be overpacked in shielded containers/casks for low specific activity (LSA) or Type A shipments. The quantity of SNM in the debris packages is a significant factor affecting the availability of off-site disposal.

RH LLW ion exchange resins are generated from pool and reactor operations at RTC and from pool operations at NRF. Resins from RTC are packaged in EPICORETM II liners. The liners are transferred in a Nuclear Packaging (NuPac) 14-210L container for disposal in the LLW disposal pit at RWMC. The INL's NuPac 14-210L cask is currently used for on-site transport of ATR ion exchange resins to the RWMC for disposal. This cask is certified as a DOT Specification 7A package for LSA resins. The cask fully satisfies DOT requirements as a Type A package. ATR ion exchange resin is 
generated about four to six times per year from reactor loop and reactor ion exchange systems. The generation rate depends on reactor operations and also varies during the years when core internal change outs are performed. ATR operations generally attempt to fill the cask volume with resins from both resin sources to efficiently use the cask volume. The NuPac cask has not previously been received at off-site disposal facilities; therefore, a dry run shipment to the off-site disposal facility would be required to train personnel on the use of the cask.

NRF resins have similar characteristics and are disposed in the same manner as NRF activated metals and are included in the same material profile. The NRF resins are currently packaged in liners and transported in 55-ton scrap casks to the SDA facility for disposal in vaults.

RH LLW activated metals from NRF are currently packaged into the same 55-ton cask liners and shipped in the same 55-ton scrap cask that is used for transporting NRF resins on-site. The 55-ton scrap cask cannot be used for transport on public highways. The NuPac 14-210L cask used for ATR resins does not provide the shielding needed for the activated metal waste. For shipment off-site, DOT Type B cask systems will be required. Shipment by rail can accommodate a larger rail-loaded cask system, while shipment by truck will necessitate a truck-loaded cask. This difference affects the options discussed for off-site disposal. One candidate site, Hanford, can accept rail shipments and one, NTS, will require truck shipments (see Appendix B). NRF is well-suited for using the larger rail-loaded cask system, as it involves minimal infrastructure changes and NRF has a rail spur to its facility. MFC and ATR lack rail spurs; therefore, a truck-loaded cask system is needed. 


\section{OFF-SITE OPTIONS FOR LOW-LEVEL WASTE DISPOSAL}

This section evaluates off-site options for all LLW. LLW is divided, for the purposes of this report, into four subcategories: CH LLW and three types of RH LLW waste (debris, resins, and activated metal). This section presents all the LLW options and summarizes the options analysis applied.

\subsection{Selection of Off-Site Facilities for Evaluation}

Off-site facilities were identified and evaluated according to the process described in Section 1. Each candidate facility is described, subjected to screening criteria, selected based on viability, and assessed by waste type relative to cost, schedule, and risk.

\subsubsection{Candidate Facility Descriptions}
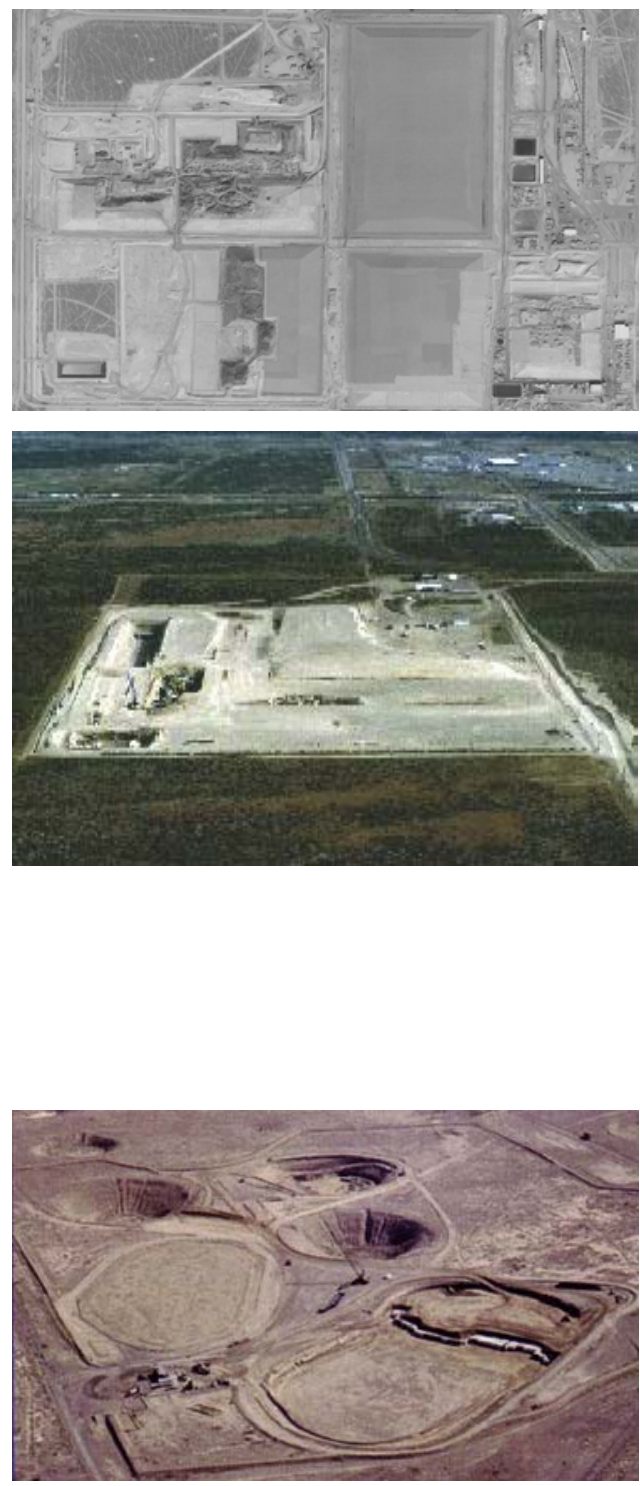

EnergySolutions is located in Tooele County, Utah. It can accept only Class A type LLW as classified under NRC standards. The State of Utah administers the NRC program for facility licensing. Licenses are issued for 5 years. The existing license has been in effect since renewal was requested in 2003 .

U.S. Ecology is located on 100 acres of land at the DOE Hanford site that are leased by the State of Washington from DOE. The facility can accept Class A, B, and C waste. The State of Washington administers the NRC program for facility licensing. The existing license is valid through 2011. Waste is placed in trenches that are typically $850-\mathrm{ft}$ long, $1,150-\mathrm{ft}$ wide, and 45 -ft deep. To date the facility has received about $13,500,000 \mathrm{ft}^{3}$ of LLW and it has a remaining capacity of $44,000,000 \mathrm{ft}^{3}$. This disposal facility is for Northwest and Rocky Mountain Compact states. Disposal of LLW that is the responsibility of the Federal government is subject to state approval. It is likely, given the repeated efforts by the State of Washington to prevent off-site waste from going to Hanford that any DOE move to send waste to U.S. Ecology would be met with resistance from the state.

The NTS occupies about 1,375 square miles in southeastern Nye County, Nevada. The site is operated by the DOE and regulated under DOE Order 435.1 for radioactive waste management. The facility is scheduled to operate through 2027. Waste is disposed in trenches. 

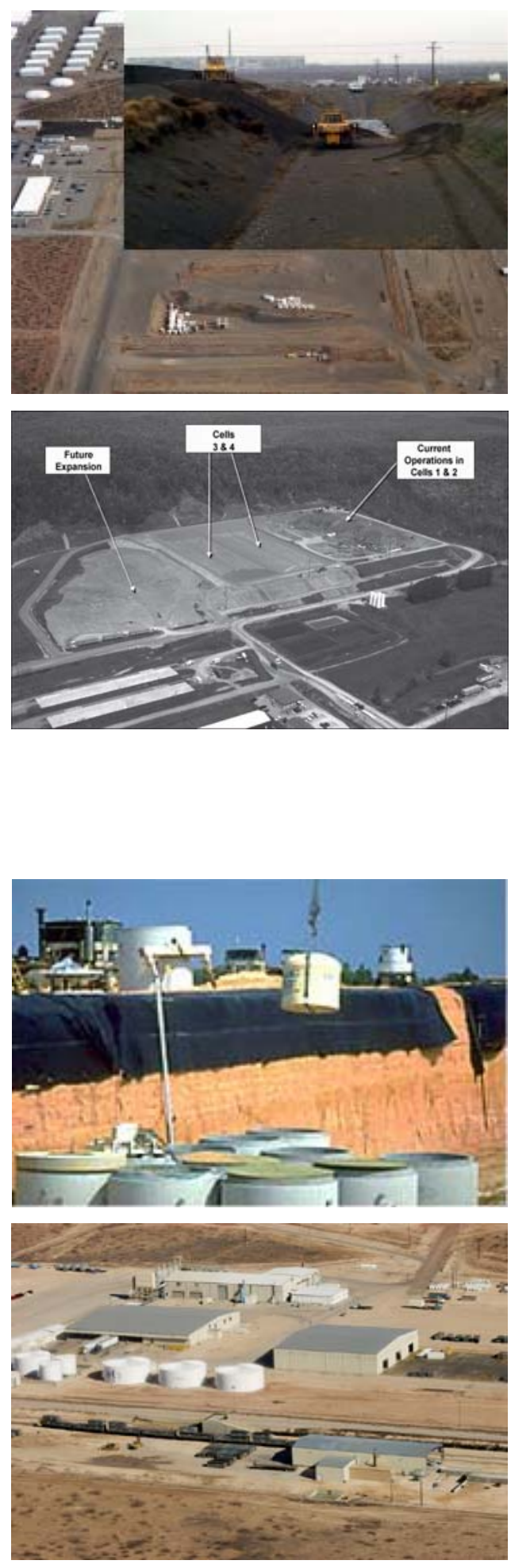

Waste Control Specialists (WCS) is planning a facility located in Andrew County, Texas, that will support the disposal of federal LLW and Texas Compact waste in separate landfill cells. A total capacity of $11,340,000 \mathrm{yd}^{3}$ is proposed for the 1,338 acre site. The facility is currently permitted for treatment and storage of LLW and the treatment and disposal for hazardous waste. WCS applied for a license from the State of Texas, the NRC authorized licensing authority, for disposal of Class A, B, and C LLW. The issuance date for this license application by the state, as well as any conditions or limitations placed on the license by the state, are uncertain. Texas has a state law that requires DOE to take possession of the site after closure, if a "federal waste" site is opened. DOE has not made a policy decision to accept future liability for the site after closure. 


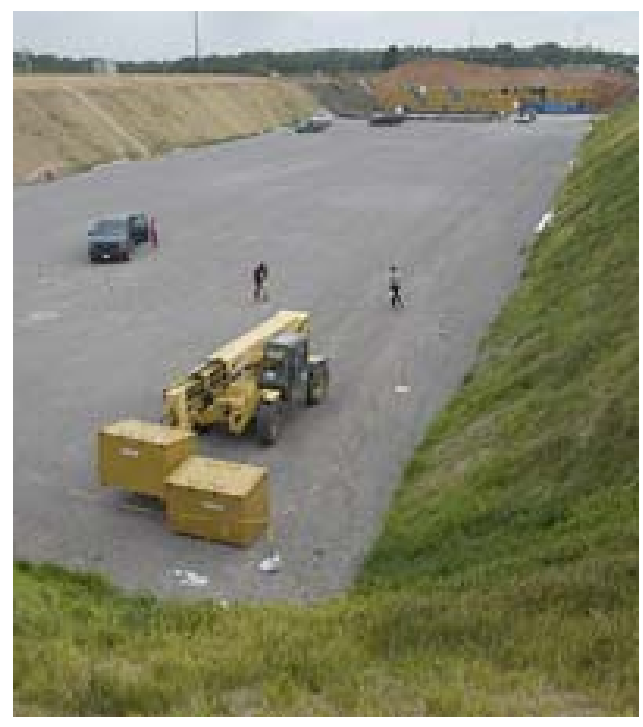

Savannah River Site (SRS) LLW disposal operations are located in the central part of the SRS in South Carolina. The disposal facility is regulated by DOE under DOE Order 435.1. It includes engineered concrete vaults for low-activity and intermediate-activity waste disposal. LLW is also disposed in trenches if it is very low in radioactivity. The trenches are equipped with a sump to sample and collect runoff. In support of the Navy's mission, SRS accepts RH LLW activated metal components generated by the Navy from off-site. SRS is not open to disposal of any other off-site wastes.

\subsubsection{Candidate Facility Screening}

Several disposal facilities have the capacity to accept all or part of the INL Site's LLW. Although wastes can be sent to multiple facilities, additional consideration is given to facilities that can accept a majority of waste because only one or minimal additional certification need be maintained. This reduces cost, quality issues, and overall project risk. One facility, NTS, was selected for purposes of developing costs. This section summarizes the rationale for selection of NTS. While NTS was selected as the off-site option for cost evaluation, other disposal facilities remain an option. The availability and capacity of the other facilities will continue to be evaluated and pursued on an ongoing basis upon commencement of off-site disposal. For a comprehensive screening analysis of facilities for CH LLW and RH LLW disposal, see Appendix B.

The following three off-site facilities were readily eliminated from further consideration because they cannot receive any of the INL Site waste types at this time:

- $\quad$ WCS, Texas, does not yet have a license to accept LLW for disposal. The schedule for licensing and the limitations and conditions that might be attached to the license are too uncertain at this time to consider this facility as a disposal option.

- $\quad$ Barnwell, South Carolina, plans to cease accepting LLW from states outside the Southeast Compact beginning in 2008 .

- $\quad$ EMWMF, Oak Ridge, Tennessee, is not authorized to accept waste from generators off the facility site.

The remaining facilities selected for analysis as an off-site disposal option for the $\mathrm{CH}$ and $\mathrm{RH}$ LLW waste streams were further evaluated based upon assessments of their WAC and their availability for disposal of INL Site LLW in the timeframe needed. The detailed assessments are provided in Appendix B of this report. Table 3-1 summarizes the results of this assessment for the remaining five candidate off-site facilities by waste type.

The following sub-sections provide detailed rationale associated with the screening criteria results for the candidate facilities. 
EnergySolutions. Most, but not all of the INL Site's CH LLW would meet the WAC. The EnergySolutions WAC has specific requirements for loading SNM. Specifically excluded are any packages containing more than 200 grams of ${ }^{233} \mathrm{U}$ in any single package. The RH LLW debris packages exceed this WAC requirement. The RH resins exceed the WAC relative to ${ }^{137} \mathrm{Cs},{ }^{90} \mathrm{Sr}$, and ${ }^{99} \mathrm{Tc}$. The RH LLW activated metal waste will normally be Class B or C; therefore, it will exceed the EnergySolutions WAC limits. INL RH LLW activated metals, including waste that would be classified as $\mathrm{B}$ or $\mathrm{C}$ under NRC standards, will not meet the EnergySolutions WAC.

U.S. Ecology. Most, but not all of the INL Site's CH LLW waste will meet the WAC. The U.S. Ecology Radioactive Material License has specific requirements for loading SNM. Specifically excluded are any packages containing more than 60 grams of ${ }^{233} \mathrm{U}$ in any single package. The RH LLW debris packages exceed this license requirement. The INL Site's resin waste stream is expected to meet the disposal acceptance requirements. The portion of the activated metals exceeding Class $\mathrm{C}$ limits could not be disposed of at U.S. Ecology.

These impacts could cause U.S. Ecology to reject the waste. Finally, U.S. Ecology has not received DOE waste to date, and U.S. Ecology would need to open a dialogue with the State of Washington to reach agreement on the acceptance of the waste. Given the repeated efforts by the State of Washington to prevent off-site waste from going to Hanford, any proposal to receive DOE waste at U.S. Ecology could be met with resistance from the state.

The $\mathrm{RH}$ activated metal waste that is Class $\mathrm{B}$ and $\mathrm{C}$ is expected to meet the disposal acceptance requirements; however, there exists a portion of the waste that exceeds 10 CFR 61 Class $C$ that could not be accepted. The activated metal characteristically has significant quantities of ${ }^{14} \mathrm{C},{ }^{63} \mathrm{Ni},{ }^{59} \mathrm{Ni}$, ${ }^{60} \mathrm{Co}$, and ${ }^{3} \mathrm{H}$ over a 25 -year disposal schedule which in some cases could have significant impact on the disposal facility's license radiological limits.

SRS. SRS can accept only NRF RH LLW activated metal for disposal by either truck or rail. However, it cannot accept RH LLW activated metal from ATR or MFC, RH LLW debris, RH LLW resins, nor CH LLW. Therefore, it is screened from consideration as a primary option. It may be reviewed in the future for NRF's activated metals if the NTS or Hanford options are not available.

Hanford LLWBG. While there are no technical barriers to accepting the INL waste, Hanford LLWBG is not available for out-of-state waste disposal until at least September 2008, when the NEPA evaluation of waste disposal is scheduled to be complete. This evaluation entails the completion of a Record of Decision (ROD) on the EIS for waste disposal and tank closure. Based on anticipated stakeholder resistance, there is a high probability that the schedule for the EIS will be extended. If the current schedule is adhered to, there would be a delay from FY 2007 to FY 2009 before AMWTP debris waste could be shipped, negatively impacting plans to complete disposition of RH LLW debris by 2012. All of the INL Site CH LLW meets the Hanford WAC. Resins would require procedural changes at the Hanford facility prior to initiating shipments.

The disposal of activated metals at Hanford suffers from the same uncertainty as do the other waste streams for the INL Site. However, shipment of activated metals involves development of a cask system suitable for rail shipment of NRF RH LLW activated metals (to minimize infrastructure changes at NRF) that will be ready in approximately FY 2014. It is assumed the Hanford facility will have completed the NEPA process and will be available by the time cask design and procurement is completed. Therefore, the Hanford facility is a potentially viable, but a high-risk option for the disposal of RH LLW activated metals. 
Table 3-1. Disposal facility screening: Waste Acceptance Criteria compliance and availability relative to low-level waste types ${ }^{\mathrm{a}}$.

\begin{tabular}{|c|c|c|c|c|c|c|c|c|c|c|}
\hline \multirow[b]{2}{*}{$\begin{array}{l}\text { Waste } \\
\text { Type }\end{array}$} & \multicolumn{2}{|c|}{ EnergySolutions } & \multicolumn{2}{|c|}{ U.S. Ecology } & \multicolumn{2}{|c|}{ LLBG-Hanford } & \multicolumn{2}{|r|}{ NTS } & \multicolumn{2}{|r|}{ SRS } \\
\hline & $\begin{array}{c}\text { Viable } \\
\text { (Yes/No) }\end{array}$ & Rationale & $\begin{array}{c}\text { Viable } \\
\text { (Yes/No) }\end{array}$ & Rationale & $\begin{array}{c}\text { Viable } \\
\text { (Yes/No) }\end{array}$ & Rationale & $\begin{array}{c}\text { Viable } \\
\text { (Yes/No) }\end{array}$ & Rationale & $\begin{array}{c}\text { Viable } \\
\text { (Yes/No) }\end{array}$ & Rationale \\
\hline CH LLW & Partial & $\begin{array}{l}\text { Not all meets } \\
\text { WAC }\end{array}$ & Partial & $\begin{array}{l}\text { Not all meets } \\
\text { WAC } \\
\text { State regulator } \\
\text { buy-in required } \\
\text { to receive DOE } \\
\text { waste }\end{array}$ & No & $\begin{array}{l}\text { Unresolved } \\
\text { NEPA issues }\end{array}$ & Yes & $\begin{array}{l}\text { Waste meets } \\
\text { WAC } \\
\text { Considered } \\
\text { routine waste } \\
\text { disposal }\end{array}$ & No & $\begin{array}{l}\text { Cannot receive } \\
\text { off-site CH } \\
\text { LLW }\end{array}$ \\
\hline $\begin{array}{l}\text { RH LLW } \\
\text { Debris }\end{array}$ & No & $\begin{array}{l}\text { SNM content } \\
\text { exceeds WAC }\end{array}$ & No & $\begin{array}{l}\text { SNM content } \\
\text { exceeds WAC }\end{array}$ & No & $\begin{array}{l}\text { Unresolved } \\
\text { NEPA issues }\end{array}$ & Yes & $\begin{array}{l}\text { Special PA } \\
\text { needed to accept } \\
\text { high fissile } \\
\text { content }\end{array}$ & No & $\begin{array}{l}\text { Cannot receive } \\
\text { off-site RH } \\
\text { LLW debris }\end{array}$ \\
\hline $\begin{array}{l}\text { RH LLW } \\
\text { Resins }\end{array}$ & No & $\begin{array}{l}\text { Exceeds WAC } \\
\text { limit }\end{array}$ & Yes & $\begin{array}{l}\text { State regulator } \\
\text { buy-in required } \\
\text { to receive DOE } \\
\text { waste }\end{array}$ & No & $\begin{array}{l}\text { Unresolved } \\
\text { NEPA issues }\end{array}$ & Yes & $\begin{array}{l}\text { Waste meets } \\
\text { WAC } \\
\text { Considered } \\
\text { routine waste } \\
\text { disposal }\end{array}$ & No & $\begin{array}{l}\text { Cannot receive } \\
\text { off-site RH } \\
\text { LLW resins }\end{array}$ \\
\hline $\begin{array}{l}\text { RH LLW } \\
\text { Activated } \\
\text { Metals }\end{array}$ & No & $\begin{array}{l}\text { Exceeds WAC } \\
\text { limit }\end{array}$ & Partial & $\begin{array}{l}\text { A portion of } \\
\text { the waste } \\
\text { exceeds Class } \\
\text { C }\end{array}$ & Yes & $\begin{array}{l}\text { NEPA issues will } \\
\text { be resolved by } \\
\text { the time this } \\
\text { waste can be } \\
\text { shipped }\end{array}$ & Yes & $\begin{array}{l}\text { Waste } \\
\text { conditionally } \\
\text { meets WAC } \\
\text { (special PA } \\
\text { requirement) }\end{array}$ & Partial & $\begin{array}{l}\text { Only NRF } \\
\text { activated metal } \\
\text { components } \\
\text { can be } \\
\text { accepted }\end{array}$ \\
\hline
\end{tabular}


NTS. The INL LLW meets the elements of the NTS WAC or is a viable candidate for a special performance assessment (e.g., the RH LLW debris containing fissile material). NTS has extensive experience disposing RH waste. RH LLW resins and activated metals can be accepted by NTS with some infrastructure changes at NRF to accommodate waste packaging.

The State of Nevada participates in review of waste material profiles and has access to LLW disposal waste information through an Agreement in Principle with DOE (DOE-NV 1999). NTS identified no issues that would cause the state to view the activated metals as unacceptable for disposal, although the facility has not received routine shipments of high-radiation waste of this nature in the past. There are anticipated impacts to the facility's infrastructure; however, they have not been fully assessed. In addition, the political climate could change by 2014 and be less favorable. LLW disposal cells at the NTS are currently scheduled to close in 2027 . This poses a risk that if NTS is selected, it will only be available for 14 years, and that large financial investments in disposing at NTS will yield limited returns.

Screening Results. Since it appears that all the INL Site's waste can be disposed of at NTS and it is currently available, it was selected for further analysis. Since NTS is suitable for all LLW, the INL Site would only need to maintain one certification program for waste shipments, minimizing costs of program administration and oversight. Further evaluation will also be given to Hanford as a potential disposal option for the RH activated metals.

\subsection{Screening Analysis for Off-Site Disposal of Contact-Handled Low-Level Waste}

It is assumed that all CH LLW will be disposed off-site beginning in FY 2009. The following section of the report provides the assumptions, strategies, and associated cost, schedule and risks associated with disposal at NTS. This screening analysis was conducted in accordance with the process flow illustrated in Figure 1-1.

\subsubsection{Assumptions and Strategies}

For this CH LLW off-site disposal option it is assumed that:

- $\quad$ The entire CH LLW inventory can be shipped off-site for disposal. No technical barriers have been identified.

- $\quad$ Costs are based upon shipment and disposal in cargo containers, with each shipment containing $36 \mathrm{~m}^{3}$ of waste.

- No changes in infrastructure, or shipping and packaging, are anticipated in order to achieve off-site disposal. Waste that is currently disposed in the pit will be packaged in compliance with DOT requirements.

- Waste profiles will be developed by INL Site waste generators and approved by NTS by October 2008.

\subsubsection{Schedule}

Disposal of CH LLW generated at the INL Site can begin in October 2008 (FY 2009) and will continue through FY 2035. 


\subsubsection{Cost}

Costs were developed based on selection of NTS as the disposal facility. Total cost of disposal at NTS is $\$ 322$ million. Shipments are assumed to continue through 2035. Costs for disposal at NTS are based on current disposal costs. Costs for transportation and disposal were escalated in accordance with DOE escalation rates, and with an appropriate contingency applied.

\subsubsection{Risk}

LLW disposal cells at NTS are currently scheduled to close in 2027 in conjunction with the planned completion of the DOE EM mission. This poses a risk that NTS will not be available for disposal of CH LLW generated beyond this date. However, the facility has disposal capacity beyond 2027, and there is the possibility the closure date can be extended ${ }^{\mathrm{b}}$.

Future disposal costs are uncertain as costs charged to the generator in a given year are based upon the total amount of waste disposed at the facility. There is a risk that disposal costs will increase as the volume of waste shipped to NTS from other generators decreases over time and that the INL Site costs will therefore also increase to support NTS base facility disposal operations costs. There is the possibility that toward the end of NTS' operating life, if INL is the only remaining generator, the INL Site will have to support the full burden of the facility, currently estimated to be $\$ 15.7$ million per year. In that event, other disposal locations, if available, would also have to be considered.

\subsection{Screening Analysis for Off-Site Disposal of Remote-Handled Low-Level Waste - Debris}

Debris is a finite waste stream requiring disposition out to 2012. This screening analysis was conducted in accordance with the process flow illustrated in Figure 1-1.

\subsubsection{Assumptions and Strategies}

The debris stored at the AMWTP facilities does not meet the WAC for the existing on-site disposal facility due to fissile activity. Off-site disposal options were reviewed based upon the assumption that the waste containers for the debris will be acceptable and re-packaging will not be required. The debris is a legacy waste and no further generation of this waste type is expected. The waste is planned to be shipped between 2007 and 2012. NTS certification is required and is currently being pursued by AMWTP. Depending on the ${ }^{233} \mathrm{U}$ activity level, a small fraction of these waste packages may not be suitable for this disposal option.

Commercially available overpacks can be used to ship RH LLW debris to NTS using LSA or Type A transport. It is assumed the waste containers still meet the requirements of Type B packaging, or, as an alternative, the packaging can be "grandfathered" into current regulations or an exception from the DOT requirement attained from and approved by DOT. Therefore, no infrastructure changes are anticipated.

Nine shipments per year at $2.8 \mathrm{~m}^{3}$ per shipment are assumed.

\subsubsection{Schedule}

The schedule for RH LLW debris is presented in Figure 3-1.

\footnotetext{
${ }^{\mathrm{b}}$ Minutes of a teleconference with Nevada Test Site, May 16, 2006.
} 


\section{Schedule for RH LLW Debris}

\begin{tabular}{|c|c|c|c|c|c|c|c|}
\hline \multirow{2}{*}{$\begin{array}{l}\text { FY07 FYo } \\
\text { Material } \\
\text { profile/develop } \\
\text { approval }\end{array}$} & FY09 & FY10 & FY11 & FY12 & FY13 & FY14 & FY15 \\
\hline & & & & & & & \\
\hline Routine off-site d & isposal & & & & & & \\
\hline
\end{tabular}

Figure 3-1. Schedule for off-site disposal activities for remote-handled low-level waste debris.

\subsubsection{Cost}

Costs for off-site disposal of RH LLW debris were estimated based on use of rented containers and support equipment. Each shipment per year will involve a 10 -day rental estimated at $\$ 6,753$ each. One material profile will be developed, the cost of which is included in the transportation and disposal costs. Costs of transportation and disposal are escalated in accordance with DOE escalation rates with an appropriate contingency applied. Total costs through FY 2012 are \$13 million.

\subsubsection{Risk}

There is a risk that the existing Type B packaging will not be acceptable. If the current configuration cannot be "grandfathered" or otherwise approved, then physical verification will be required and the drums will need to be opened and repackaged to meet the regulations.

NTS has received RH LLW in the past. The State of Nevada participates in review of waste material profiles and has access to LLW disposal waste information through an Agreement in Principle with DOE (DOE-NV 1999). No issues have been identified that will cause the state to view the debris waste stream as unacceptable for disposal although some packages within the waste stream may not be suitable for this disposal path.

\subsection{Screening Analysis for Off-Site Disposal of Remote-Handled Low-Level Waste - Resins}

Resins generated by RTC and NRF are evaluated in this section for off-site disposal to NTS beginning in October 2009. This screening analysis was conducted in accordance with the process flow illustrated in Figure 1-1.

\subsubsection{Assumptions and Strategies}

Assumptions and strategies used to develop this option include:

- $\quad$ Disposal will be required through 2035.

- $\quad$ NRF's current method of shipment will not meet DOT requirements. Two CNS21-300 (Type A) transport casks are commercially available and of equivalent size to NRF's current operations.

- $\quad$ Modifications to NRF infrastructure will be required to accomplish off-site disposal. NRF will need to design a loading station for a commercial cask or repackage to a different resin disposal liner/system. 
- $\quad$ The EPICORETM II liners from RTC are currently shipped in a NuPac 14-210L shipping container for shielding. It is assumed this procedure will be acceptable for off-site shipments.

- $\quad$ RTC is estimated to require six shipments per year with $6 \mathrm{~m}^{3}$ in each shipment. NRF will have two shipments per year for its $8 \mathrm{~m}^{3}$ of waste. A total of eight shipments per year are planned.

- Waste profiles will be developed by INL Site waste generators and approved by NTS by October 2009.

\subsubsection{Schedule}

The schedule for disposal off-site for RH LLW resins, presented in Figure 3-2, includes infrastructure development at NRF.

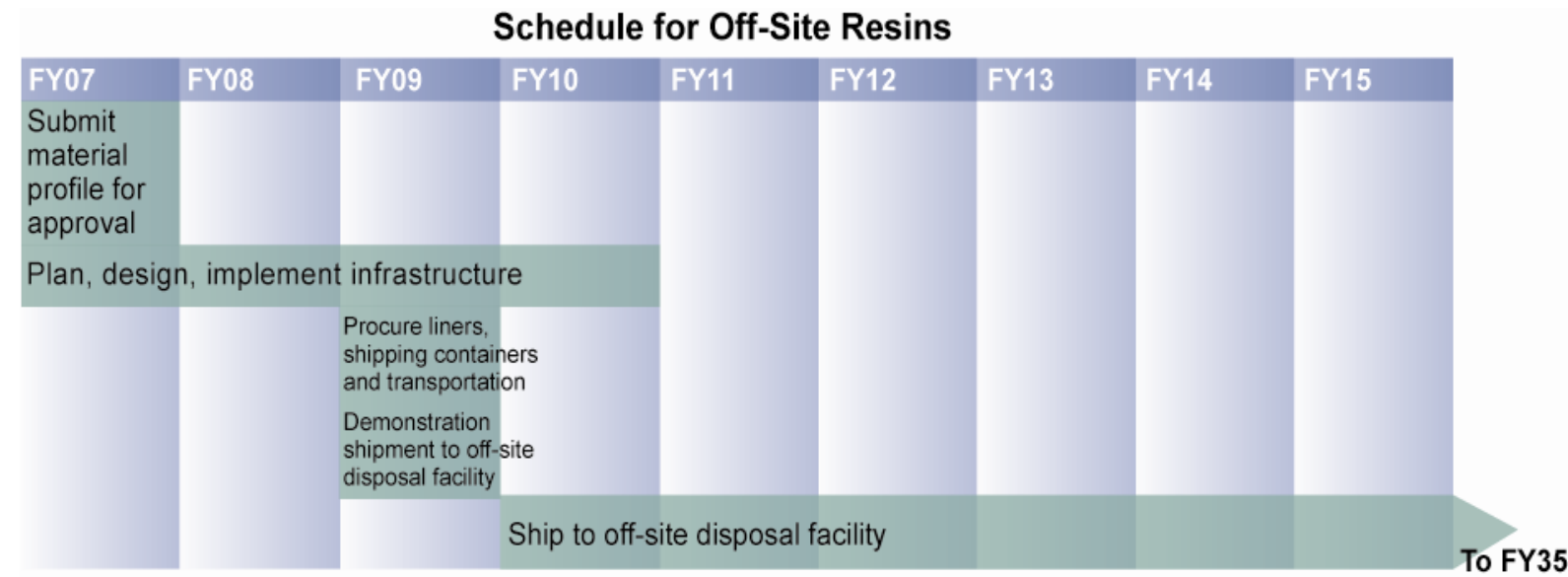

Figure 3-2. Schedule for off-site disposal activities for remote-handled low-level waste resins.

\subsubsection{Cost}

The costs for preparation and off-site disposal of resins at NTS from FY 2007 through FY 2035 include escalation throughout the performance period, and appropriate contingencies are associated with each activity. Total costs through 2035, which include both NRF and RTC resins, are \$69 million.

There are anticipated impacts to the facility's infrastructure associated with changes to operating procedures; however, they have not been fully assessed and are therefore not included. Costs for disposal at NTS are based on current charges. However, future disposal costs are uncertain as costs charged to the generator in a given year are based upon the total amount of waste disposed at the facility. Additionally, costs may increase if the disposal site, NTS, needs to recover costs for required infrastructure changes.

These costs for the disposal of RH LLW resins are based on renting shipping containers for seventen day rental periods per year. However, further cost evaluation is needed to determine whether it is more feasible to purchase shipping containers. It is assumed that the type of resin liners currently used by the RTC at the ATR will continue to be used for ATR and will be used for NRF as well. One material profile will be developed. 


\subsubsection{Risk}

LLW disposal cells at NTS are currently scheduled to close in 2027. This poses a risk that NTS will not be available for disposal of CH LLW generated beyond this date. The facility has disposal capacity beyond 2027, and there is the possibility the closure date can be extended (DOE-NV 1999).

Future disposal costs are uncertain as costs charged to the generator in a given year are based upon the total amount of waste disposed at the facility. There is a risk that disposal costs will increase as the volume of waste shipped to NTS over time decreases. The INL Site costs could increase significantly to support NTS base facility disposal operations costs. There is the possibility that toward the end of NTS' operating life, the INL Site will have to support the full burden of the facility, currently estimated to be $\$ 15.7$ million per year.

NTS has received RH waste in the past. The State of Nevada participates in review of waste material profiles and has access to LLW disposal waste information through an Agreement in Principle with DOE (DOE-NV 1999). No issues have been identified that would cause the state to view the resins as unacceptable for disposal.

\subsection{Screening Analysis for Off-Site Disposal of Remote-Handled Low-Level Waste - Activated Metals}

Activated metals pose the greatest challenge to off-site disposal due to the amount of shielding required for transportation and transfer operations. This section presents NTS and Hanford as alternative options for off-site disposal. This screening analysis was conducted in accordance with the process flow illustrated in Figure 1-1.

\subsubsection{Assumptions and Strategies}

Assumptions and strategies used to perform the analysis include:

- $\quad$ New Type B casks are required to meet the configuration and shielding requirements for off-site shipment of activated metals (see Appendix E).

- $\quad$ Casks sized for truck-loaded shipments will be procured from a commercial vendor. The initial availability of these casks will be no later than October of 2011.

- $\quad$ Casks sized for rail-loaded shipments will be custom designed and fabricated specifically for INL. The first rail-loaded cask will be available no later than October of 2013.

- A dose rate of $15,000 \mathrm{R} / \mathrm{hr}$ for the RH LLW activated metals is selected for purposes of analysis. Future projections are expected to be below this level. Any waste that is over $15,000 \mathrm{R} / \mathrm{hr}$ could be stored to allow decay to this level.

- $\quad$ Temporary storage will be available at RTC and will be sufficient to store all RH LLW activated metal waste until the commercial shipping casks can be procured and authorized for use.

- Commercial truck-loaded casks will be available to support generation of RH LLW activated metals from MFC.

- While the information submitted in this section assumes the entire burden of the cost for the development of the new rail-loaded cask systems will be the INL Site's, there may be needs at 
other DOE facilities for these casks. The INL Site will continue to coordinate with other sites to identify opportunities to cooperate on cask development.

- $\quad$ NRF will have capacity to store this waste at its facility for approximately two years beyond the closure of the SDA. Although the SDA is currently scheduled to be closed in FY 2009, there will still be approximately 80 installed but unused RH LLW vaults in the SDA at that time. Based on the current CERCLA closure schedule, it is assumed that SDA will remain open for disposal of RH LLW in the vaults through FY 2012 to avoid the need to develop an interim storage facility to store NRF activated metals until the rail-loaded casks are available in 2014. This will necessitate a change in the contract(s) for BEA and/or CWI and will require communicating the change to regulators (DEQ and EPA) as well as the stakeholders.

- $\quad$ Continued use of the SDA for disposal was considered as well as several additional on-site facilities for interim storage of activated metals. Each of these facilities would have required costly modifications and the stored waste would have to be moved again for final disposal. The combination of continued use of the SDA through 2012 for permanent disposal and short-term storage ( 2 years) at generator facilities bridges the gap to final disposition without facility modifications and would minimize waste handling. Since the Baseline Risk Assessment for the SDA conservatively assumed that the maximum volume and associated source term would be emplaced and the proposed extension fits within the current CERCLA closure schedule, it is assumed that disposal of RH LLW activated metals in the vaults can be extended through 2012 .

- $\quad$ ATR will have storage in its canal through FY 2014.

- $\quad$ NTS and Hanford were selected as viable options. Shipping and packaging considerations include:

- $\quad$ Shipment by rail is not available to NTS. A commercial shipping cask that meets the weight limits for truck transport while providing sufficient shielding will be available by October of 2011. To send waste to NTS, six casks will be needed to make 50 shipments per year (44 from NRF, 4 from MFC, and 2 from RTC) at an anticipated waste generation of $44 \mathrm{~m}^{3}$. A trailer is needed for each cask. Four shielded transfer systems will also be required to accommodate disposal shipping activities. Five casks would be used by NRF and one will be shared between RTC and MFC.

- $\quad$ Hanford can accommodate shipment by rail and truck. NRF can use rail transportation because there is a rail spur to the facility. The MFC and ATR do not have rail spurs and must use truck transport. To send waste to Hanford, two rail-loaded casks will be developed to accommodate $16 \mathrm{NRF}$ activated metal shipments per year. The rail-loaded cask system would interface with NRF's existing waste operation and involve minimal changes. In addition, one commercial shipping cask system will be shared between RTC and MFC for nine shipments a year. Each system will have a trailer and a shielded transfer system.

- Infrastructure considerations for shipping off site to NTS or Hanford include:

- $\quad$ In the case of shipping to either NTS or Hanford, modifications will be required at NRF to accommodate the new cask size and associated shipping procedures will need to be developed.

- $\quad$ NTS will need to adopt specific procedures, perform special performance assessments, and rent extra equipment in order to receive and dispose of this waste. However, the extent of these modifications is not known. 
- $\quad$ Hanford will need to adopt specific procedures, perform special assessments, and rent extra equipment in order to receive and dispose of this waste. However, the extent of these modifications is not known.

\subsubsection{Schedule}

The schedule for off-site disposal of RH LLW activated metals using truck-loaded casks is presented in Figure 3-3. This schedule involves cask procurement only, as an available cask design has been identified. A truck-loaded cask would be used by ATR and MFC for shipments to NTS or Hanford. It would be used by NRF for its shipments to NTS.

\section{Schedule for Disposal of Off-Site Remote Handled Metals Using Truck-Loaded Casks}

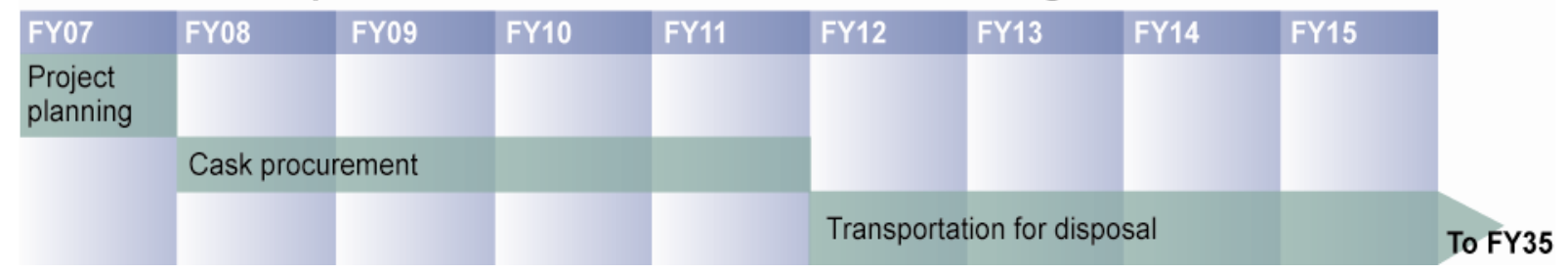

Figure 3-3. Schedule for off-site disposal activities for remote-handled low-level waste activated metals using truck-loaded casks.

The schedule for disposal off-site of RH LLW activated metals using a rail-loaded cask is presented in Figure 3-4. The schedule includes time for cask development, including licensing. The rail-loaded cask is used only for shipments from NRF to Hanford. A truck-loaded cask would be used by ATR/MFC for shipments to NTS or Hanford. Truck-loaded casks would be used by NRF for its shipments to NTS. The schedule for the truck-loaded cask involves cask procurement only as an available truck-loaded cask design is identified.

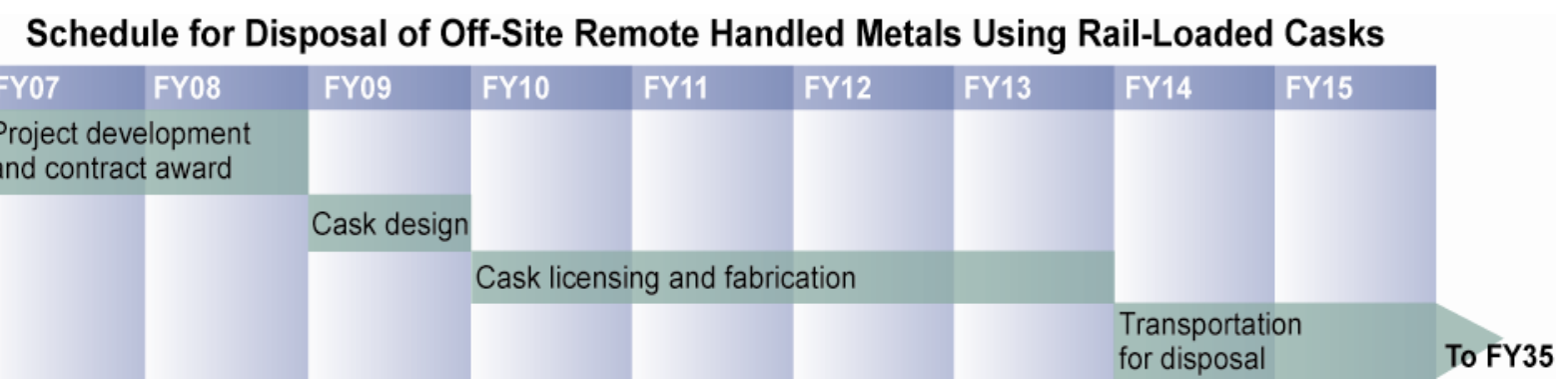

Figure 3-4. Schedule for off-site disposal activities for remote-handled low-level waste activated metals using rail-loaded casks.

\subsubsection{Cost}

Costs for shipment to NTS include acquisition of casks and purchase of 50 cask liners per year for 26 years. NTS maintenance and training costs are included, but costs of infrastructure changes have not been fully assessed and are therefore are not included. Transportation and disposal costs include development of material profiles and waste characterization. Costs are escalated in accordance with DOE escalation rates with an appropriate contingency applied. Costs for the NTS option are $\$ 413$ million.

Costs for shipment to Hanford include development and acquisition of casks, and purchase of 25 cask liners per year. Transportation and disposal costs include development of material profiles and 
waste characterization. Costs are escalated in accordance with DOE escalation rates with an appropriate contingency applied. Costs for the Hanford option are \$174 million.

\subsubsection{Risk}

LLW disposal at the NTS is an EM program on a National Nuclear Security Administration (NNSA) site. EM is planning to transfer ownership of the LLW disposal cells at the NTS in 2027 to the NNSA. The facility has disposal capacity beyond 2027 but disposal of LLW after 2028 will have to be agreed to by the NNSA. This poses a risk that the facility will not be available beyond 2027 (DOE-NV 1999).

Future disposal costs are uncertain as costs charged to the generator in a given year are based upon the total amount of waste disposed at the facility. There is a risk that disposal costs will increase as the volume of waste shipped to NTS over time decreases and therefore the INL Site disposal costs could increase to support NTS base facility disposal operations costs. There is the possibility that toward the end of NTS' operating life, the INL Site will have to support the full burden of the facility, currently estimated to be $\$ 15.7$ million per year.

NTS has received RH LLW in the past. The State of Nevada participates in review of waste material profiles and has access to LLW disposal waste information through an Agreement in Principle with DOE (DOE-NV 1999). NTS identified no issues that would cause the state to view the activated metals as unacceptable for disposal, although the facility has not received routine shipments of highradiation waste of this nature in the past, and impacts to the facility's infrastructure have not been fully assessed. In addition, the political climate could change by 2014 and be less favorable.

There is a risk that Hanford will remain closed to off-site disposal when the INL Site is prepared to ship. The rail-loaded cask that had been developed to ship waste to Hanford by rail will not be suitable for shipments to NTS. However, SRS could receive rail shipments of NRF RH LLW activated metals only as a second course of action if Hanford is not available.

The 5- to 7-year schedule for cask deployment is extremely aggressive, particularly given the number of casks that must be available. The 25 to 50 shipments per year under this alternative scenario (16 to 44 shipments per year from NRF) would severely impact primary missions at the INL Site, including NRF's ability to support the fleet and meet the settlement agreement commitments.

Stakeholders, including the State of Washington, have resisted using Hanford for disposal of waste from out-of-state and will continue their opposition (Seattle-Post Intelligencer 2006). The EIS currently scheduled for completion in September 2008 will likely be challenged through litigation, which will cause further delay.

Shipment of activated metals requires a large upfront investment to develop and/or procure Type B cask systems for transport. As such, there is significant risk associated with a commitment of resources to secure these cask systems without assurance of facility acceptance (by Hanford in particular).

Continued operation of the SDA until 2012 to accommodate the schedule for the rail-mounted casks is based on the current WAG 7 CERCLA closure schedule; however, if continued operation negatively impacts planned closure activities, the development of additional on-site storage capacity for the NRF activated metals may be necessary.

Continued operation of the SDA to accommodate the schedule for the rail-mounted casks could meet with some resistance from stakeholders and regulators; however, the risk is minimal given the concerns of continued operation are primarily focused on the disposal cell, and continued disposal of activated metal in the vaults is fully bounded under the CERLA risk assessment. 


\section{ON-SITE DISPOSAL OPTIONS}

\subsection{Siting and Design Considerations for On-Site Disposal of Idaho National Laboratory Low-Level Waste}

For these options, it was assumed that the LLW inventory will be retained and disposed of on-site beginning at the earliest availability of an operational on-site disposal facility. No technical barriers have been identified that will prevent implementation of an on-site option.

Two options are examined for new on-site disposal. One is a new facility for all LLW waste. The second is a facility designed for disposal of RH LLW activated metals only.

\subsubsection{Siting}

Selection of a candidate location for on-site disposal at the INL Site is subject to the requirements of DOE Order 435.1 and implementing guidance for LLW facilities. A siting evaluation must consider the environmental characteristics, geotechnical characteristics, and human activities. An LLW disposal facility location study must specifically address: suitability for volume of waste, flood plain, tectonic activity, water table fluctuation, access, wildlife, whether radionuclide migration pathways are predictable, and whether erosion and surface runoff can be controlled.

Several such studies have been prepared for proposed INL Site facilities. There are also substantial data regarding site conditions available from the environmental monitoring, sampling and analysis, and other studies that are routinely performed at the INL Site. A study conducted in 1997 includes an evaluation of 16 candidate locations at the INL Site (INEEL 1997). The study was performed for one specific waste stream from separation of calcined and liquid waste with a projected volume of $25,000 \mathrm{~m}^{3}$. It provides an excellent baseline for further evaluation for the wastes described in this report. It screened sites according to four "must" criteria:

- $\quad$ Avoid the 100-year floodplain

- $\quad$ Avoid wetlands

- $\quad$ Avoid critical habitat of endangered species

- Avoid areas in which tectonic processes may affect ability of the facility to meet performance objectives or may preclude defensible prediction of long-term impacts.

Sites that passed the screening were assessed for 19 criteria that addressed minimizing impacts to resources, accessibility, suitability for waste volume and expansion, and impeding downward migration of contaminants. The study identified several locations on the INL Site suitable for a LLW landfill. The data and criteria in the 1997 study will have to be updated, and the locations reconsidered in light of the different waste volumes and characteristics, but it is likely that a similar conclusion will be reached for the LLW that is the subject of this report.

Full consideration of the siting issues for candidate sites is outside the scope of this report. For the purpose of this analysis, we have assumed that a suitable location for an LLW disposal facility exists at the INL Site, and that a site will be generally suitable both technically and economically as a disposal facility location. 
Once a site is identified by optimizing all the technical and cost parameters, additional geotechnical investigation is needed to confirm suitability and identify a specific location for the facility. The costs for planning, conducting field work, and reporting on results comprise the costs for siting included in the cost estimate given further below in this section of the report. The data so generated will be used to complete the facility design.

Apart from those considerations already discussed for an on-site landfill for CH LLW, no additional considerations for siting a new facility for disposal of only RH LLW have been identified. It is assumed that a suitable site could be located for a new RH LLW disposal facility.

\subsubsection{Disposal Facility Description/WAC}

This section further considers the option to build and maintain a disposal facility on the INL Site specifically designed to safely dispose of LLW through 2035. Operation of the new landfill will begin $1-1 / 2$ to $2-1 / 2$ years after the cessation of existing SDA disposal operations for $\mathrm{RH}$ and $\mathrm{CH}$, respectively. This will necessitate a period of off-site shipments in both cases.

Expected Volumes of Waste. For this preliminary analysis of an on-site LLW disposal cell, the assumption is that a CH LLW volume of $4,000 \mathrm{~m}^{3}$ per year will be generated. To account for disposal packing inefficiencies and cover material, this conceptual design uses an $85 \%$ fill efficiency. Therefore, to accommodate a $4,000 \mathrm{~m}^{3} /$ year generation rate, approximately $4,706 \mathrm{~m}^{3}$ of $\mathrm{CH}$ LLW disposal volume will be needed each year. If the on-site disposal facility operates from 2010 to 2035, the total estimated volume of CH LLW disposal within this shallow burial facility will be $\left(4,706 \mathrm{~m}^{3}\right.$ per year for 25 years $)$ approximately $117,650 \mathrm{~m}^{3}$.

The CH LLW disposal facility will consist of two cells. Cell 1 will have a nominal depth of $6 \mathrm{~m}$, a surface footprint of $12,951 \mathrm{~m}^{2}$ (3.20 acres), and a waste disposal volume of $62,500 \mathrm{~m}^{3}$. Cell 2 will have a nominal depth of $6.5 \mathrm{~m}$, a surface footprint of $11,243 \mathrm{~m}^{2}$ (2.78 acres), and a waste disposal volume of $55,150 \mathrm{~m}^{3}$. Phased construction in the form of two cells permits later design changes if actual waste generation rates deviate from design projections.

In addition to the CH LLW, an on-site facility planned as the disposal site for LLW must accommodate the RH LLW as well. The projected annual average generation rate of RH LLW resins and activated metals is estimated to be approximately $88 \mathrm{~m}^{3}$ through 2035 . Of the expected $88 \mathrm{~m}^{3}$ of RH LLW, $36 \mathrm{~m}^{3}$ are RTC resins that have previously been disposed of in pits at the RWMC. The other RH LLW activated metal waste types currently disposed of at the RWMC are disposed of in the concrete vaults (see Figure 4-1).

The new on-site facility design will dispose of all RH LLW waste in concrete vaults. The number of RH concrete vaults required is based on the configuration of vaults and the transportation containers used by the generating facilities rather than the volumetric fill efficiency. Two configurations of concrete vaults will be constructed in the new on-site facility. The first design is based on the RWMC vaults, which are suitable for the 55-ton cask liner used by NRF for transport of RH LLW. These vaults are made from pre-cast concrete. They have a circular cross section and are approximately $1.5 \mathrm{~m}$ in diameter and $6 \mathrm{~m}$ high. These vaults can accommodate two stacked 55-ton cask liners $(1.22 \mathrm{~m}$ diameter by $2.82 \mathrm{~m}$ high). Each liner holds approximately $3 \mathrm{~m}^{3}$ of waste. The number of this type of cask required is determined by the planned shipping schedule from the generator facilities. 


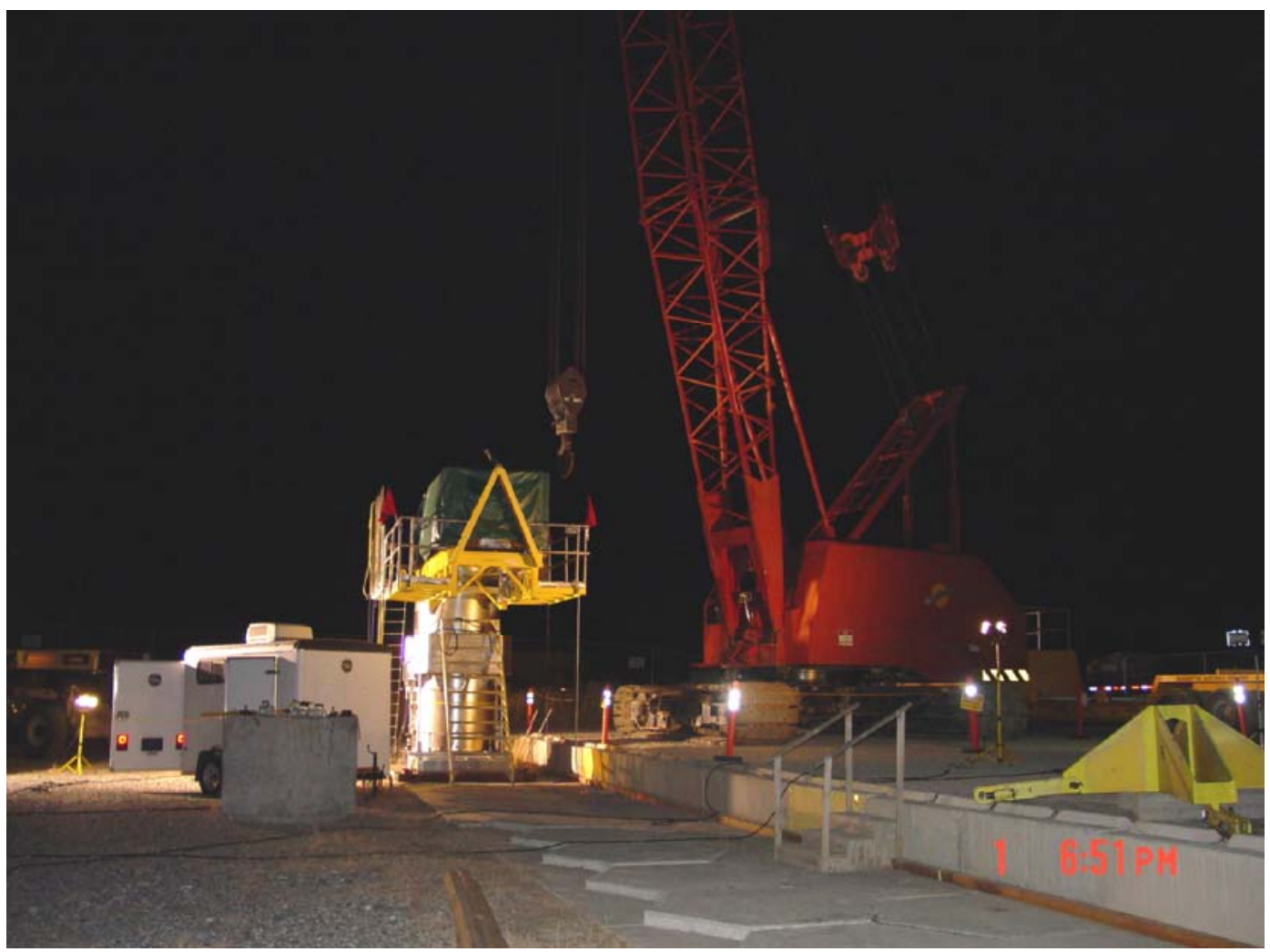

Figure 4-1. RH concrete vaults.

The projected annual average of RH LLW is estimated to be approximately 88 cubic meters. Of the expected $88 \mathrm{~m}^{3}$ of RH LLW, $52 \mathrm{~m}^{3}$, comprising all RH LLW activated metals and NRF resins, will be disposed of in the concrete vaults of this design. At $6 \mathrm{~m}^{3}$ of this type of RH LLW waste per vault, approximately eight vaults will be needed each year. For the assumed 25 -year operation period approximately 200 vaults will be needed. These vaults will be constructed in two sets of 100 each, the second set being constructed beginning in FY 2019. Phased construction of the vaults permits changes to the number of vaults in the second set if actual waste generation rates differ from design projections.

The second vault design is based on the configurations of the containers used by RTC for transport of RH LLW resins. These vaults are also made from pre-cast concrete. They are approximately $2.1 \mathrm{~m}$ in diameter and $6 \mathrm{~m}$ high. These vaults are larger to accommodate the EPICORE ${ }^{\mathrm{TM}}$ II liners. One vault can hold a single liner, each liner holding approximately $6 \mathrm{~m}^{3}$ of waste resin. The number of this type of cask required is determined by the planned shipping schedule from the generator facilities. Approximately six shipments per year are planned, each of which will contain a single liner. To accommodate six shipments per year for 25 years, 150 of this type of vault will be required.

In addition to the wastes from NRF, ATR, and MFC there are also RH LLW debris wastes located at AMWTP. These wastes are scheduled to be disposed of by 2012. Total volume of this RH LLW debris waste is estimated at $150.25 \mathrm{~m}^{3}$. As a contingency against this waste not being shipped according to the planned schedule, a sufficient number of vaults were included in the design of the new on-site facility to accommodate this waste although it is recognized that some of the waste packages within this waste stream may not be suitable for this disposal path due to the ${ }^{233} \mathrm{U}$ activity levels. The debris wastes are in 55- or 110-gal drums. These may be staged in 7-packs of 55-gal drums or 3-packs of 110-gal drums. These configurations can be disposed of in the second vault design described above. A total of 50 vaults are needed to provide a contingency for all of the RH LLW waste. 
To dispose of all of the RH LLW debris and RTC resins, 200 vaults of the second design are included in the facility design. These vaults will be constructed in two sets of 100 each, the second set being constructed beginning in FY 2019. Phased construction of the vaults permits changes to the number of vaults in the second set if actual waste generation rates differ from design projections.

\subsection{Analysis of On-Site Disposal of All Low-Level Waste}

\subsubsection{Assumptions and Strategies}

The approach taken was to use existing information from the Idaho CERCLA Disposal Facility (ICDF) project with modifications to cost and schedule to reflect the current projected waste volumes for LLW, NEPA regulations (42 USC § 4321) versus CERCLA regulations (42 USC § 9601), safety analysis assumptions for a Hazard Category 2 facility, and RH LLW disposal. The following assumptions and strategies were used to develop the cost and schedule for the new on-site LLW disposal facility:

- $\quad$ Costs for RH LLW vaults are based on actual costs for the construction of new disposal vaults at RWMC between 2001 and 2003.

- $\quad$ For the purposes of developing costs for the disposal cell, a design consistent with the performance objectives for LLW disposal facilities as provided in DOE Manual 435.1-1 Chapter IV, P (1) was used.

- $\quad$ Although the landfill design assumptions do not meet Resource Conservation and Recovery Act (RCRA) Subtitle C liner requirements for mixed low level waste, the design includes engineered features that take into account operational impacts and are protective of groundwater (INL 2006, Appendix C).

- The cover design for the CH LLW cells will incorporate appropriate elements of fill, biobarriers, and evapo-transpiration cover.

- The use of removable concrete covers for the RH LLW vaults will likely simplify the cover design relative to that required over the cells.

- $\quad$ The remotely handled LLW can be handled in a similar manner as it is today at the SDA. A crane and support equipment are used to move the cask over the top of the vault, lower the liner into the vault, and seal the vault.

- $\quad$ An EA, not an EIS, will be prepared to comply with the NEPA. The EA will tier from the analyses and decisions made in the 1995 INL EIS on environmental restoration and waste management (see Appendix C). The duration for preparation of an EA will be 10 months. This assumes expeditious review and approval by DOE and minimal stakeholder opposition.

- Operational costs associated with the SDA pit and vaults were used for estimating purposes. A $30 \%$ contingency was applied and should cover any additional costs related to reasonable enhancements instituted as best management practices.

- $\quad$ No costs for changes in infrastructure for shipping, packaging, and temporary storage are anticipated to be needed in order to achieve on-site disposal of LLW. 
- Half of each set of vaults and approximately half of the landfill cell capacity will be built initially, followed by installation of the second half beginning in 2019. Phased construction of the landfill cell capacity and the vaults is planned to compensate for uncertainty in projected waste volumes.

- $\quad$ The existing waste calciner filter (WCF) cask will be used to transport activated metals from MFC and ATR to the disposal vaults.

\subsubsection{Schedule}

Figure 4-2 presents the schedule for construction of an on-site disposal facility. This schedule assumes that this facility will be developed and funded as a capital project.

\section{Schedule for On-Site LLW Facility - Landfill}

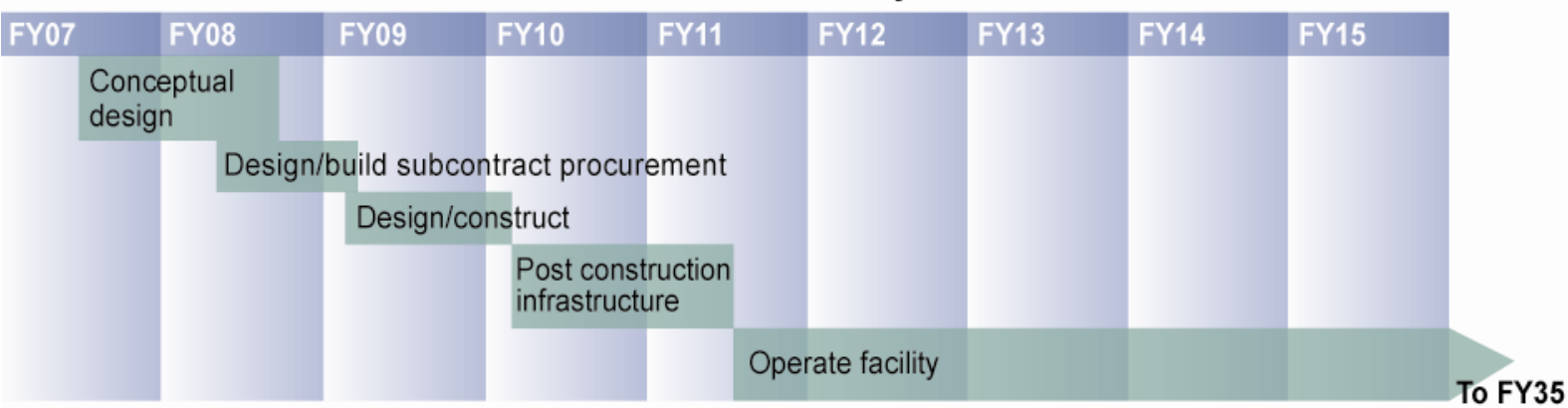

Figure 4-2. Schedule for on-site disposal facility.

\subsubsection{Costs}

The costs for disposal of CH LLW and RH LLW in an on-site disposal facility include siting, design and construction of infrastructure, maintenance of disposal authorization, safety documentation, project management, operations, and closure. Costs are escalated and include an appropriate contingency. Operational costs associated with the SDA pit and vaults were used for estimating purposes. A 30\% contingency was applied and should cover any additional costs related to reasonable enhancements instituted as best management practices. Costs for the on-site disposal facility total $\$ 271$ million. If the decision were made to construct the landfill cells with artificial liners and leachate collection, the capital, operational, and off-site shipment costs will increase and the start-up of the facility could be delayed until March 2012. This 10-month slide in schedule could necessitate the use of the SDA for disposal of NRF $\mathrm{RH}$ activated metals and/or the development of interim storage capacity on-site given NRF's two-year storage limitation.

\subsubsection{Risk}

An on-site landfill will be regulated by DOE. Stakeholders will have involvement through the NEPA process and other established public and regulator forums as appropriate. If the option of a new facility is selected, stakeholder concerns about location can be addressed via the site selection criteria used in the facility siting assessment. Stakeholders have also expressed concerns that a new INL facility would be made available for disposal of waste from off-site; however, use of the INL for off-site waste disposal is not a decision DOE has made pursuant to NEPA. The INL is restricted to disposal of LLW from on-site only based on DOE's ROD for LLW (DOE 2000). Concerns for protection of the aquifer have been paramount and therefore stakeholder reactions to disposal of LLW on-site could be mixed. In particular, concern could be expressed regarding the fact that the landfill cells are not equipped with artificial liners. Stakeholder perceptions on the applicability of a liner may induce a strong reaction and could impact cost and schedule. 


\subsection{Screening Analysis for On-Site Disposal of Remote-Handled Low-Level Waste - Activated Metals}

Activated metals pose a great challenge to off-site disposal because of the amount of shielding required to safely manage the waste. This section evaluates the option of on-site disposal of RH LLW activated metals only due to the unique shipping and transportation issues involved with off-site disposal.

\subsubsection{Assumptions and Strategies}

The approach to analyzing on-site disposal of RH LLW activated metals involved identification of those parts of the cost and schedules for the on-site disposal facility that are required for a new facility for disposal of activated metals. The costs, schedule, and risk for a new facility for disposal of RH LLW metals only are presented.

Construction of a disposal facility for RH LLW activated metals involves installation of concrete vaults. This option assumes the RH LLW debris and RH LLW resins will be shipped to an off-site disposal facility. Therefore, unlike the case where all LLW is disposed of on-site, this option requires only one type of vault. To accommodate RH LLW activated metals only, 200 vaults are estimated to be required to be installed. Costs for the RH LLW vaults were based upon the actual design and cost for the construction of vault storage at the RWMC between FY 2001 and FY 2003.

For a stand alone facility for disposal of RH LLW activated metals, it is assumed that the schedule for installation of the vaults for all of the RH LLW activated metals will be the same as that for installation of vaults in the new facility described in Section 4.2.

Assumptions and strategies used to perform the analysis include:

- $\quad$ NRF has temporary storage for this waste at its facility through FY 2011. ATR has temporary storage in its canal through FY 2012.

- Installation of the first set of RH LLW vaults will align with the schedule previously presented for construction of an on-site landfill. The second set of vaults will be procured and installed beginning in FY 2019.

\subsubsection{Schedule}

The schedule for construction of a disposal facility for RH LLW is the same as the schedule for construction of a landfill, see Figure 4-2.

\subsubsection{Cost}

The costs for disposal in the RH LLW vaults on-site include installation of the vaults in two phases, infrastructure, maintenance of disposal authorization and operations. Costs are $\$ 156$ million.

\subsubsection{Risk}

On-site disposal vaults will be regulated by DOE. Stakeholders will have involvement through the NEPA process and other established public involvement forums, as appropriate. Concerns about siting have been raised if the facility is located near ICDF. If the option of a new facility is selected, stakeholder concerns about location can be addressed via the site selection criteria used in the facility siting assessment. Stakeholders have also expressed concerns that a new INL facility would be made available 
for disposal of waste from off-site; however, use of the INL for off-site waste disposal is not a decision DOE has made pursuant to NEPA. The INL is restricted to disposal of LLW from on-site only based on DOE's ROD for LLW. Concerns for protection of the aquifer have been paramount and therefore stakeholder reactions to disposal of LLW on-site could be mixed. Strong reaction from stakeholders could impact cost and schedule. Risks of on-site disposal for activated metals using vaults instead of a cell are mitigated by the absence of exposed waste, minimal contamination involved with activated metals, and the more robust containment. 


\section{LOW-LEVEL WASTE DISPOSAL ALTERNATIVE SCENARIO IDENTIFICATION AND EVALUATION}

The options for LLW disposal are grouped into the four alternative scenarios in this section. Each alternative scenario encompasses all LLW disposal needs for the INL Site. The alternative scenarios are described in terms of cost, risk, and complexity. Then the scenarios are ranked according to how they stand relative to each other for each of these criteria.

More detailed cost and schedule information for each scenario, including total operating and capital costs by year, is provided in Appendix D. A present value analysis was performed for the four alternative scenarios presented in this section. The cost estimates in Appendix D provide the basis for this analysis. Office of Management and Budget guidelines were followed, including application of a $2.60 \%$ escalation and a $5.20 \%$ discount rate.

\subsection{Alternative Scenario 1: Disposal of All Low-Level Waste On-Site}

\subsubsection{Summary}

Under this alternative scenario DOE Order 435.1 standards will be followed. A landfill including RH LLW vaults will be constructed located on the INL Site and used for disposal of all of INL Site's projected LLW volumes through 2035 (see Figure 5-1). The disposal landfill will consist of shallow land burial cells with engineered features for disposal of CH LLW and two types of pre-cast vaults for disposal of RH LLW activated metals, resins, and debris. Existing data from prior studies simplifies the siting effort, with priority given to proximity to currently operating facilities. Assuming funding is available for initiating activities in 2007, this alternative scenario could be operational by May 2011. Between 2009 and 2011, off-site disposal for CH LLW, RH LLW debris, and RH LLW resins will occur and RH LLW activated metals will be stored on-site.

The following actions or approvals are needed from DOE per the schedules in Appendix D to implement Scenario 1:

- $\quad$ Critical Decision (CD) 0/1 through CD 4 for an on-site LLW landfill

- $\quad$ EA determination and Finding of No Significant Impact (FONSI) based on the EA of construction of an on-site landfill

- Disposal Authorization Statement

- Operational Readiness Review.

\subsubsection{Cost}

Total project cost for this alternative scenario is approximately $\$ 307$ million. This includes costs of off-site disposal of CH LLW, RH LLW debris, and RH LLW resins until the on-site landfill goes into operation. If the decision were made to construct the landfill cells with artificial liners and leachate collection, the capital, operational, and off-site shipment costs will increase and the start-up of the facility could be delayed until March 2012. This 10-month slide in schedule could necessitate the use of the SDA for disposal of NRF RH activated metals and/or the development of interim storage capacity on-site given NRF's two-year storage limitation. 
CH LLW Disposal Scenario 1 On-Site

\begin{tabular}{|c|c|c|c|c|c|c|c|c|c|c|}
\hline & FY07 & FY08 & FY09 & FY10 & FY11 & FY12 & FY13 & FY14 & FY15 & FY35 \\
\hline \multicolumn{11}{|c|}{$\begin{array}{l}\text { CH Off-Site } \\
\text { Disposal }\end{array}$} \\
\hline $\begin{array}{l}\text { On-Site } \\
\text { Disposal }\end{array}$ & & Landfill & & & & & & & & \\
\hline Facility & Plan & Design & & Construct & & & & Operations & & \\
\hline
\end{tabular}

\section{RH LLW Disposal Scenario 1 On-Site}

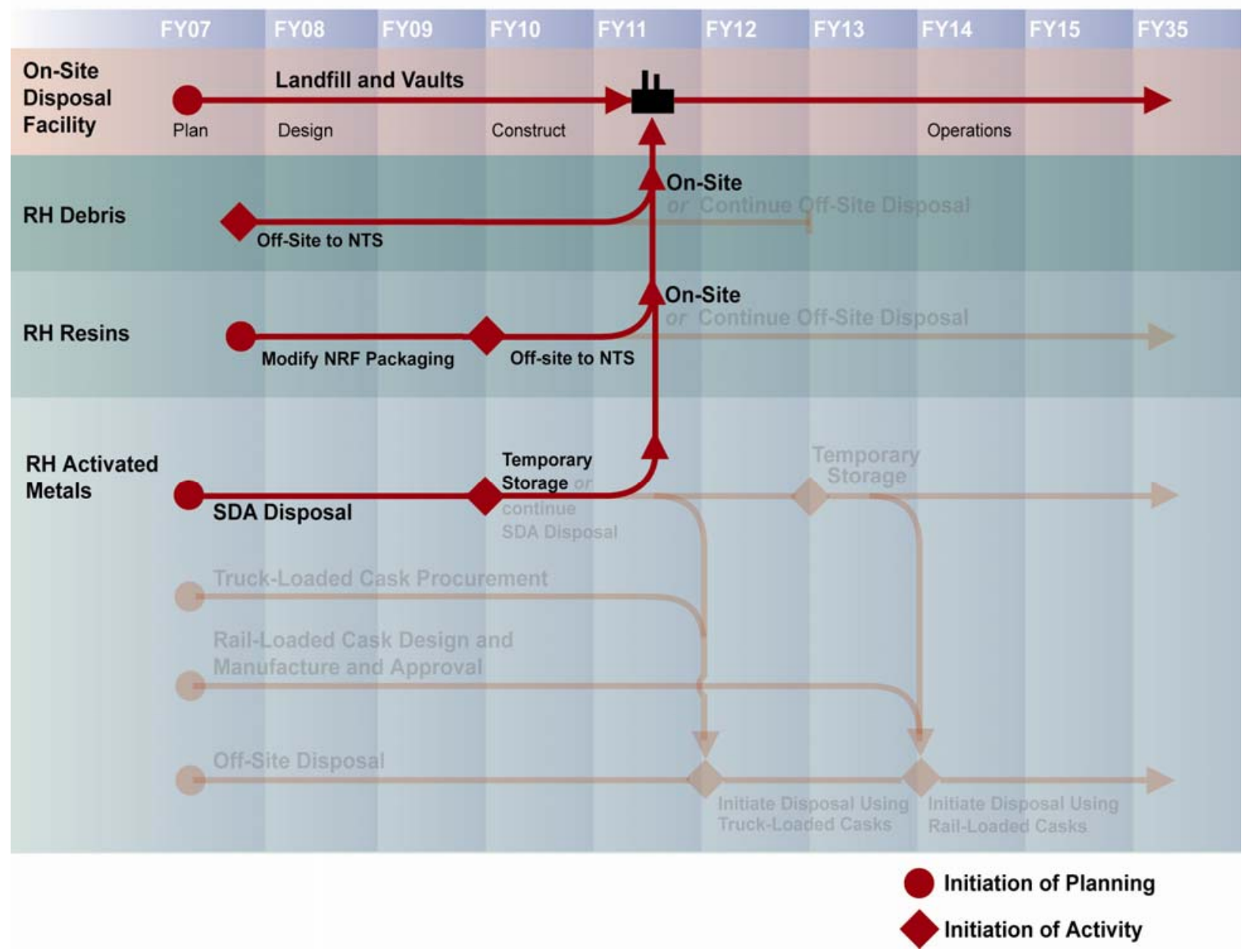

Figure 5-1. Alternative Scenario 1 - Disposal of all low-level waste on-site. 


\subsubsection{Risk}

Overall risk for this alternative scenario is considered low relative to the other scenarios because the risks involved with siting, construction, and operation are largely under the control of the DOE and do not involve out-of-state transport. The facility will be designed using experience, practices, and materials, which introduce little design risk. The potential risk of long-term impacts to the aquifer can be mitigated through use of design, operating, monitoring, and closure standards. Stakeholder reactions to disposal of LLW on-site and/or the facility design could be mixed. In particular, concern could be expressed regarding the fact the landfill cells are not equipped with artificial liners. Strong reaction from stakeholders could impact cost and schedule.

If FY 2007 funding is not available, impact to proposed schedule could require continued use of the SDA for disposal of NRF RH activated metals and/or development of interim storage for this waste stream at an on-site facility.

\subsubsection{Complexity}

This alternative scenario is very straightforward and is the least complex of all alternative scenarios. A single disposal site is involved. Since all shipments occur within site boundaries, existing transport practices and equipment can be used. This completely eliminates the costs, risks, and schedule impacts of development of a new transportation cask system and simplifies the coordination and management of shipments.

\subsection{Alternative Scenario 2: Disposal of all Low-Level Waste Off-Site at Nevada Test Site}

\subsubsection{Summary}

Under this alternative scenario, all LLW will be disposed off site at NTS (see Figure 5-2). NTS is the only off-site disposal facility able to handle all of INL's LLW. No changes in infrastructure, or shipping and packaging, are required to achieve off-site disposal of CH LLW and RH LLW debris. Shipment of CH LLW and RH LLW debris can commence on approval of waste profiles by NTS, assumed as October 2008 in the schedule.

Shipment of RH LLW resins from RTC will utilize the same INL-owned NuPac 14-210L shipping container currently used for on-site transport. Shipment of RH LLW resins from NRF will require use of commercially available Type A transport containers and infrastructure modifications at NRF to load the containers. Shipment of RH LLW resins can commence on approval of waste profiles by NTS and completion of required infrastructure and procedural changes at NRF, both assumed as completed in October 2009 in the schedule.

Shipment of activated metals to NTS will require procurement of multiple truck-loaded casks, trailers, and shielded transfer systems. Infrastructure changes at NRF will also be required to accommodate the new cask size and associated handling procedures. NTS will need to adopt specific procedures, perform special performance assessments, and rent/purchase extra equipment in order to receive and dispose of this waste. These costs have not been provided by NTS and are not included in this analysis. NTS will also need to coordinate with the State of Nevada on the review and acceptance of the RH LLW activated metal. Due to the cask systems procurement cycle, shipment of activated metals to NTS will commence at the end of FY 2011 assuming capital project requirements and that funding is available in FY 2007 to initiate required activities. 


\section{CH LLW Disposal Scenario 2 Off-Site Disposal to NTS}

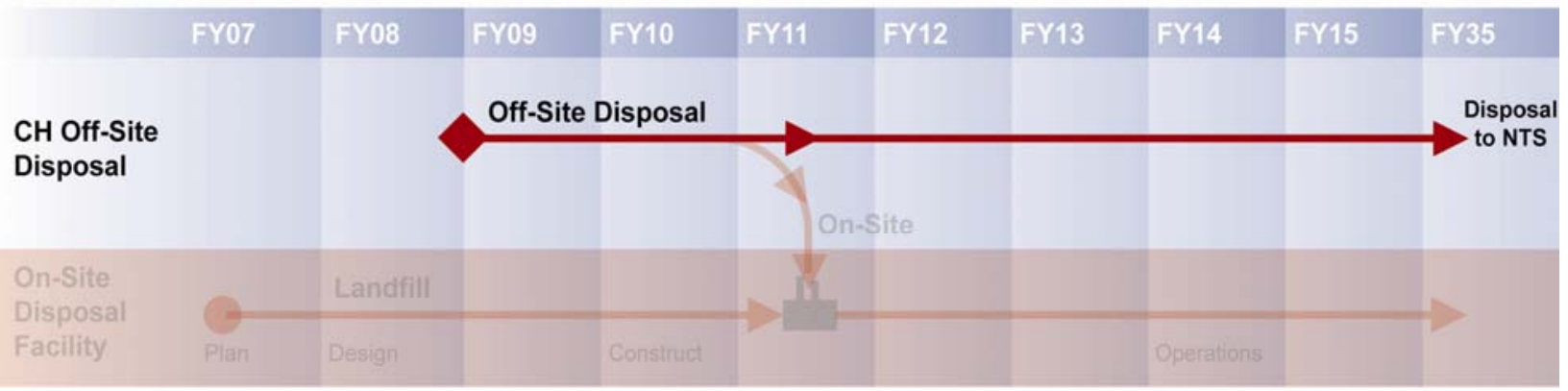

\section{RH LLW Disposal Scenario 2 Off-Site Disposal to NTS}

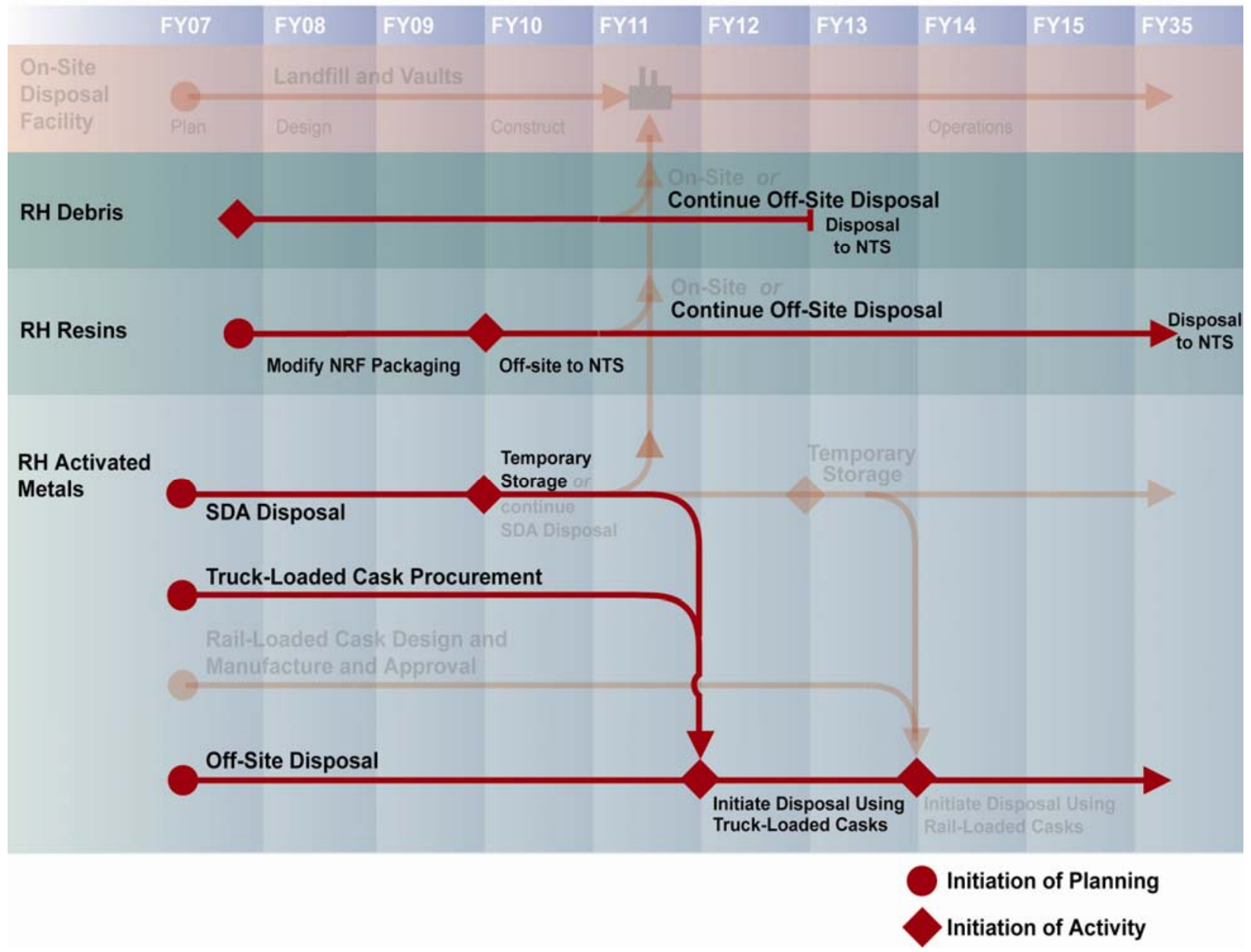

Figure 5-2. Alternative Scenario 2 - Disposal of all low-level waste off-site - Nevada Test Site. 
NRF will have capacity to store this waste at its facility for approximately two years beyond the closure of the SDA, which will allow storage at NRF until casks are available. As a contingency, continued use of the SDA should be considered in the event the schedule slips past October 2011.

Once the procurements, infrastructure changes, and procedure modifications are completed all INL Site LLW will be shipped to NTS for disposal for the remainder of the period of interest.

DOE must approve necessary funding to implement Scenario 2. Contract modification(s) will also be necessary in the event that schedule slippage requires the use of SDA vaults for disposal of RH LLW activated metals past FY 2009.

\subsubsection{Cost}

Total project cost for this alternative scenario is approximately $\$ 817$ million.

\subsubsection{Risk}

This alternative scenario is considered a medium risk relative to the other scenarios.

Shipping waste has inherent risks associated with commercial shipments of goods.

NTS is regulated by the DOE and disposal is not anticipated to be a problem from a technical standpoint, although the facility has not received shipments of high-radiation waste of this nature in the past and impacts to infrastructure have not been fully addressed. The State of Nevada participates in review of waste material profiles and has access to LLW disposal waste information through an Agreement in Principle with DOE (DOE-NV 1999). No issues have been identified that would cause the state to view the RH LLW as unacceptable for disposal. However, the political climate could change in the future and be less favorable to accepting these waste streams.

The 5-year schedule for cask procurement is extremely aggressive, particularly given the number of casks that must be available to support highway shipments. The 50 shipments per year under this alternative scenario ( 44 shipments per year from NRF) would severely impact primary missions at the INL Site, including NRF's ability to support the fleet and meet the settlement agreement commitments.

LLW disposal at the NTS is an EM program on a National Nuclear Security Administration (NNSA) site. EM is planning to transfer ownership of the LLW disposal cells at the NTS in 2027 to the NNSA. The facility has disposal capacity beyond 2027 but disposal of LLW after 2028 will have to be agreed to by the NNSA. This poses a risk that the facility will not be available beyond 2027, and the government will have made a large financial investment for just 14 years of disposal (DOE-NV 1999).

If FY 2007 funding is not available, impact to proposed schedule could require continued use of the SDA for disposal of NRF RH activated metals and/or development of interim storage for this waste stream at an on-site facility.

Future disposal costs are uncertain because the costs charged to the generator in any given year are based upon the total amount of waste disposed at the facility from all generators. If usage of NTS by other facilities decreases (which is currently anticipated), there is a risk that disposal costs will increase to cover more of NTS' operating cost burden.

There is a risk that the existing Type B packaging of RH LLW debris will not be acceptable. If the current configuration cannot be "grandfathered" or otherwise approved, then physical verification will be required and the drums will need to be opened and repackaged to meet the regulations. 
Shipping activated metal waste to NTS results in a single point failure if NTS is unable to receive the waste due to stakeholder or regulator concerns and Hanford is not available. If Hanford can receive RH LLW activated metal at that point, the shipments could be diverted to Hanford for disposal.

While the State of Idaho and stakeholders may view this alternative scenario in a positive light in that waste will be leaving the state, stakeholders outside the state may have a negative view.

\subsubsection{Complexity}

This alternative scenario is more complex than Alternative Scenarios 1 and 4, but less complex than Alternative Scenario 3. Only a single ultimate disposal site is involved. However, in addition to the direct work required to implement the alternative scenario, an additional project must be conducted to acquire new shipping cask systems. Juggling the interrelated cost and schedule demands of two projects, one of which includes participation by the agency for cask certification, introduces a measure of complexity and risk into this alternative scenario.

\subsection{Alternative Scenario 3: Disposal of Contact-Handled Low-Level Waste, Remote-Handled Debris, and Remote-Handled Resins at Nevada Test Site; Disposal of Remote-Handled Activated Metals at Hanford}

\subsubsection{Summary}

Under this alternative scenario, all LLW except the RH LLW activated metals will be shipped to NTS. (see Figure 5-3). For all of the INL Site LLW streams except RH LLW activated metals, this alternative scenario is identical to Alternative Scenario 2. No changes in infrastructure, or shipping and packaging, are required to achieve off-site disposal of CH LLW and RH LLW debris. Shipment of CH LLW and RH LLW debris can commence on approval of waste profiles by NTS, assumed as October 2008 in the schedule.

Shipment of the RH LLW resins from RTC will utilize the same INL-owned NuPac 14-210L shipping container currently used for onsite transport. Shipment of RH LLW resins from NRF will require use of commercially available Type A transport containers and infrastructure modifications at NRF to load the containers. Shipment of RH LLW resins can commence on approval of waste profiles by NTS and completion of required infrastructure and procedural changes at INL Site, both assumed as completed in October 2009 in the schedule.

The RH LLW activated metals will be disposed at Hanford. This option is included in this alternative scenario because Hanford has rail access and use of rail-loaded casks by NRF minimized the impacts on the facility. Shipment of activated metals to Hanford will still require design, fabrication, and procurement of a new cask system. However, for Hanford there is a significant advantage in that a larger, rail-loaded waste cask can be used for the shipments from NRF. To send waste to Hanford, two railloaded rail casks will be developed to accommodate NRF shipments and one truck-loaded cask system (cask, trailer, and transfer bell) will be procured for RTC and MFC shipments since these facilities do not have rail access. Minor infrastructure changes at RTC will also be required to accommodate the new casks and associated handling procedures. Hanford will need to adopt specific procedures, perform special performance assessments, and rent extra equipment in order to receive and dispose of the RH LLW activated metal waste, costs that are not included in this analysis. Due to the cask systems procurement cycle, shipment of activated metals to Hanford will commence in October 2011 from RTC and MFC and in October 2013 from NRF assuming capital project requirements and funding are available in FY 2007 to initiate required activities. 


\section{CH LLW Disposal Scenario 3 Off-Site Disposal to NTS and Hanford}

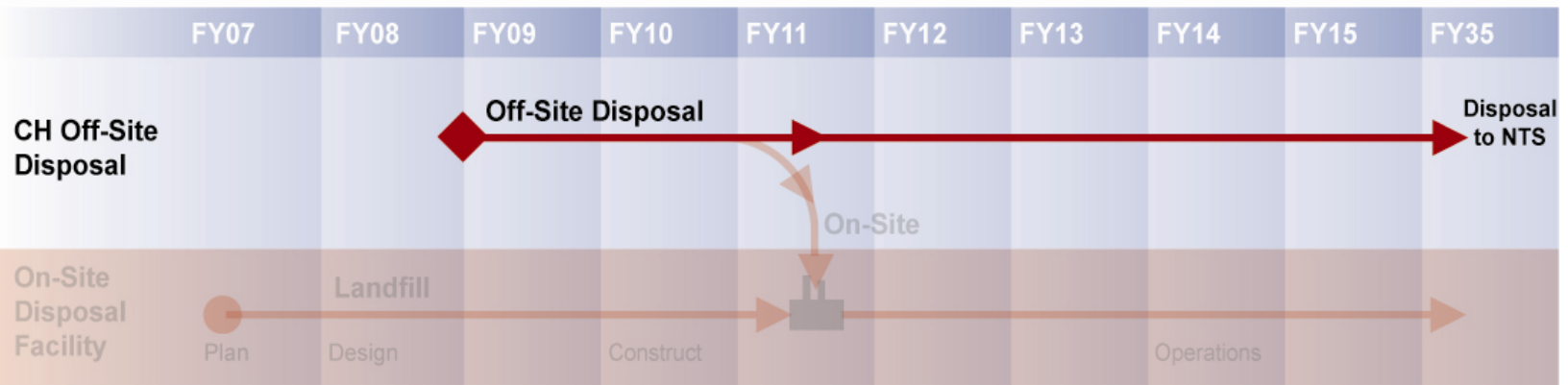

RH LLW Disposal Scenario 3 Off-Site Disposal to NTS and Hanford

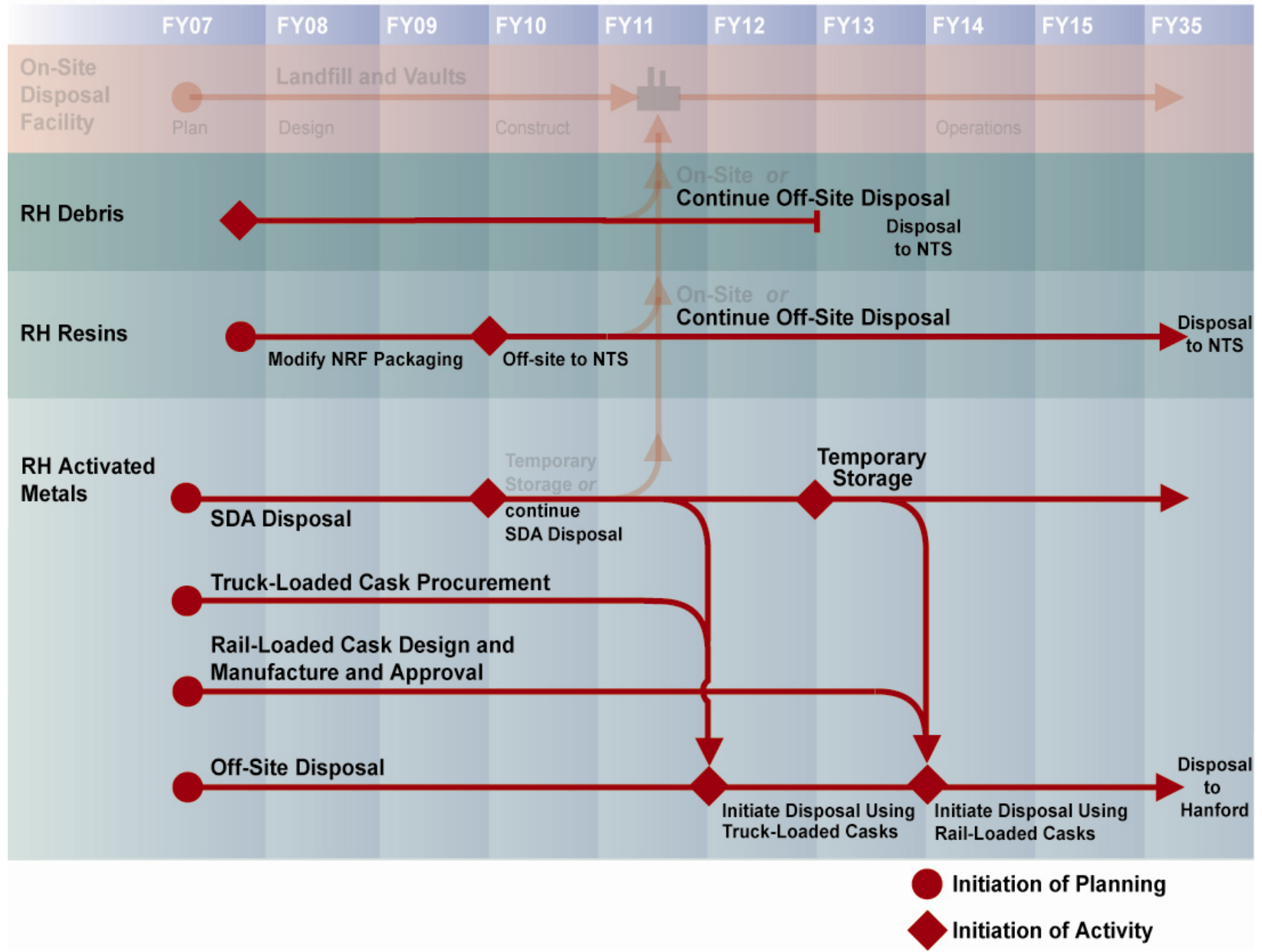

Figure 5-3. Alternative Scenario 3 - Disposal of all low-level waste off-site - Nevada Test Site/Hanford. 
NRF will have capacity to store this waste at its facility for approximately two years beyond the closure of the SDA. Although the SDA is currently scheduled to be closed in FY 2009, there will still be approximately 80 installed, unused RH LLW vaults in the SDA at that time. Additionally, the Baseline Risk Assessment for the SDA conservatively assumed that the maximum volume and associated source term would be emplaced. Based on the current CERCLA closure schedule, it is assumed that the schedule for disposal of RH LLW activated metals in the vaults will be extended through 2012. This will avoid the need to develop an interim storage facility to store NRF activated metals until the rail-loaded casks are available in 2014. This will necessitate a change in the contract(s) for BEA and/or CWI, and will require communicating the change to regulators (DEQ and EPA) as well as the stakeholders.

Continued use of the SDA for disposal was considered as well as several additional on-site facilities for interim storage of activated metals. Each of these facilities would have required costly modifications and the stored waste would have to be moved again for final disposal. The combination of continued use of the SDA through 2012 for permanent disposal and short-term storage (2 years) at generator facilities bridges the gap to final disposition without facility modifications and would minimize waste handling.

To implement Scenario 3, DOE needs to approve funding for a capital equipment project to procure the necessary rail-loaded cask systems and implement contract modification(s) to authorize continued use of the SDA vaults for disposal of RH LLW activated metals until 2012.

\subsubsection{Cost}

Total project cost for this alternative scenario is approximately $\$ 578$ million.

\subsubsection{Risks}

This alternative scenario is considered a high risk.

Shipping waste has inherent risks associated with commercial shipment of goods.

NTS is regulated by the DOE and disposal of INL Site wastes is not anticipated to be a problem from a technical standpoint. The State of Nevada participates in review of waste material profiles and has access to LLW disposal waste information through an Agreement in Principle with DOE (DOE-NV 1999). No issues have been identified that will cause the state to view the RH LLW debris and resins as unacceptable for disposal. However, the political climate could change in the future and be less favorable to accepting these waste streams.

LLW disposal at the NTS is an EM program on a National Nuclear Security Administration (NNSA) site. EM is planning to transfer ownership of the LLW disposal cells at the NTS in 2027 to the NNSA. The facility has disposal capacity beyond 2027 but disposal of LLW after 2028 will have to be agreed to by the NNSA. This poses a risk that the facility will not be available beyond 2027 and the government will have made a large financial investment for just 14 years of disposal (DOE-NV 1999).

Future disposal costs are uncertain because the costs charged to the generator in any given year are based upon the total amount of waste disposed at the facility from all generators. If usage of NTS by other facilities decreases (as currently anticipated), there is a risk that disposal costs will increase to cover more of NTS' operating cost burden.

There is a risk that the existing Type B packaging of RH LLW debris will not be acceptable. If the current configuration cannot be "grandfathered" or otherwise approved, then physical verification will be required and the drums will need to be opened and repackaged to meet the regulations. 
There is a risk that Hanford will remain closed to off-site disposal when the INL Site is prepared to ship. The rail-loaded casks that had been developed to ship waste to Hanford by rail will then not be suitable for shipments to NTS. Stakeholders have effectively resisted use of Hanford for disposal of waste from out of state and will likely continue their opposition. There is therefore significant risk associated with the commitment of resources to secure these rail-loaded cask systems without assurance of acceptance of the waste by Hanford.

While the State of Idaho and stakeholders may view this alternative scenario in a positive light (waste will be leaving the state), stakeholders outside the state may have a negative view.

Continued operation of the SDA until 2012 to accommodate the schedule for the rail-mounted casks is based on the current WAG 7 CERCLA closure schedule; however, if continued operation negatively impacts planned closure activities, the development of additional on-site storage capacity for the NRF activated metals may be necessary.

Continued operation of the SDA to accommodate the schedule for the rail-mounted casks could meet with some resistance from the stakeholders and regulators; however, the risk is minimal given the concerns of continued operation are primarily focused on the disposal cell, and continued disposal of activated metal in the vaults is fully bounded under the CERLA risk assessment.

\subsubsection{Complexity}

This alternative scenario is the most complex of any of the alternative scenarios evaluated. Two different off-site facilities are used for disposal of INL Site LLW waste. This will lead to the development of two separate systems and sets of procedures for certification and shipping waste. In addition to the direct work required to open and use the two disposal pathways, two additional parallel projects must be conducted to acquire two new, different shipping cask systems, rail-loaded rail and truck-loaded trailer. Juggling the interrelated cost and schedule demands of these projects introduces a significant measure of complexity into this alternative scenario.

\subsection{Alternative Scenario 4: \\ Shipment of Contact-Handled Low-Level Waste, Remote-Handled Resins, and Remote-Handled Debris to Nevada Test Site; Disposal of Remote-Handled Activated Metals On-Site}

\subsubsection{Summary}

Under this alternative scenario, all LLW except the activated metals will be shipped to NTS (see Figure 5-4). For all of the INL Site LLW streams except RH LLW activated metals, this alternative scenario is identical to Alternative Scenarios 2 and 3. No changes in infrastructure, or shipping and packaging, are required to achieve off-site disposal of CH LLW and RH LLW debris. Shipment of CH LLW and RH LLW debris can commence on approval of waste profiles by NTS, assumed as October 2008 in the schedule.

Shipment of the RH LLW resins from RTC will utilize the same INL-owned NuPac 14-210L shipping container currently used for onsite transport. Shipment of RH LLW resins from NRF will require use of commercially available Type A transport containers and infrastructure modifications at NRF to load the containers. Shipment of RH LLW resins can commence on approval of waste profiles by NTS and completion of required infrastructure and procedural changes at INL Site, both assumed as completed in October 2009 in the schedule. 
CH LLW Disposal Scenario 4 Off-Site

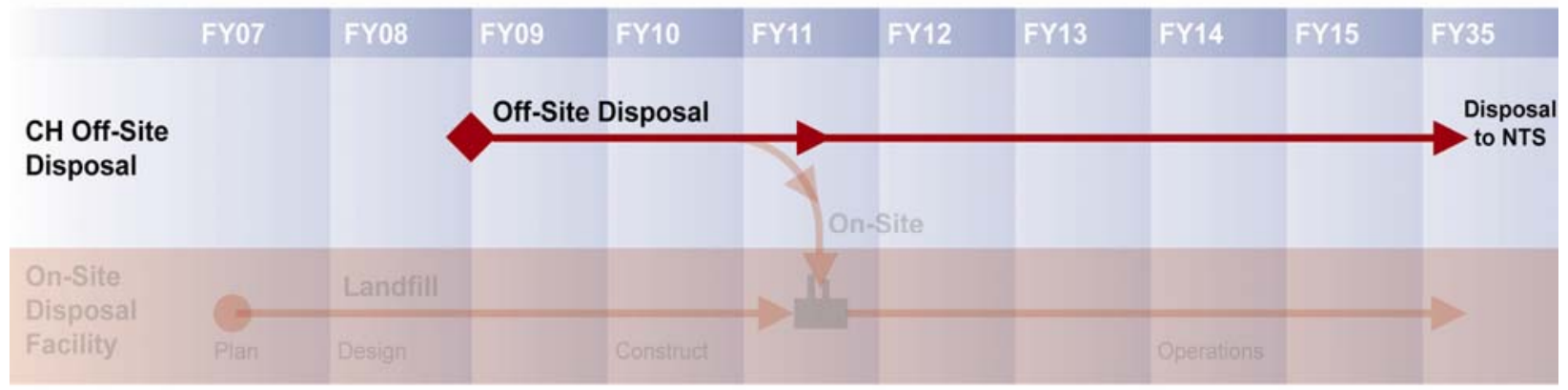

RH LLW Disposal Scenario 4 Resins and Debris Off-Site; Metals On-Site

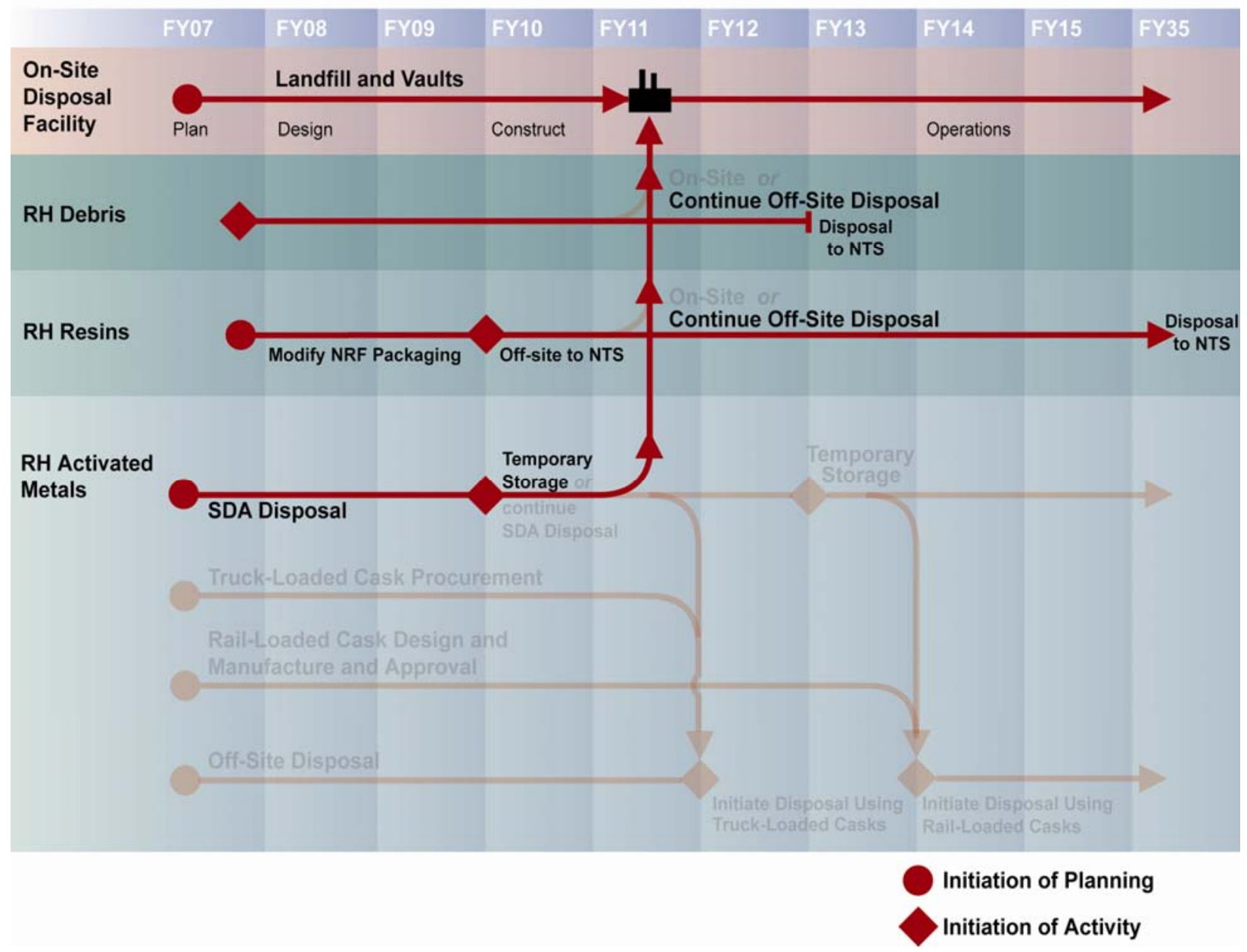

Figure 5-4. Alternative Scenario 4 - Disposal of low-level waste off-site to Nevada Test Site (debris and resins) and on-site (metals). 
Under this alternative scenario, a stand-alone concrete vault disposal system will be constructed on the INL Site and used for disposal of all of INL Site's RH LLW activated metals through 2035. The system will consist of pre-cast vaults for disposal of RH LLW activated metals. Existing data from prior studies simplifies the siting effort, with priority given to proximity to currently operating facilities. Assuming funding is available for initiating activities in 2007, this alternative scenario could be operational by May 2011.

The following actions or approvals are needed from DOE to implement Scenario 4:

- $\quad$ CD 0/1 through CD 4 for an on-site LLW landfill

- $\quad$ EA determination and FONSI based on the EA of construction of an on-site landfill

- Disposal Authorization Statement

- Operational Readiness Review.

DOE must approve necessary funding to implement scenario 4. Contract modification(s) would also be required in the event that schedule slippage requires the use of SDA vaults for disposal of RH LLW activated metals past FY 2009.

\subsubsection{Costs}

Total project cost for this alternative scenario is approximately $\$ 555$ million.

\subsubsection{Risks}

This alternative scenario is considered a medium risk relative to the other scenarios.

Shipping waste has inherent risks associated with commercial shipment of goods.

NTS is regulated by the DOE and disposal of INL Site wastes is not anticipated to be a problem from a technical standpoint. The State of Nevada participates in review of waste material profiles and has access to LLW disposal waste information through an Agreement in Principle with DOE (DOE-NV 1999). No issues have been identified that will cause the state to view the RH LLW as unacceptable for disposal.

LLW disposal cells at NTS are currently scheduled to close in 2027. This poses a risk that NTS will not be available for disposal and the government will have made a large investment for just 14 years of disposal. However, the facility has disposal capacity beyond 2027, and there is the possibility the closure date can be extended (DOE-NV 1999).

Future disposal costs at NTS are uncertain because the costs charged to the generator in any given year are based upon the total amount of waste disposed at the facility from all generators. If usage of NTS by other facilities decreases (which is currently anticipated), there is a risk that disposal costs will increase to cover more of NTS' operating burden.

There is a risk that the existing Type B packaging of RH LLW debris will not be acceptable. If the current configuration cannot be "grandfathered" or otherwise approved, then physical verification will be required and the drums will need to be opened and repackaged to meet the regulations. 
The disposal of RH LLW activated metal on-site is considered low risk because the risks involved with siting, construction, and operation are largely under the control of the DOE and there is no political risk from out-of-state shipments. The facility will be designed using experience, practices, and materials used in current practices, which introduces little design risk. DOE regulates the facility and transportation off-site is not involved. Risks of on-site disposal for activated metals using vaults instead of a cell are mitigated by the absence of exposed waste, minimal contamination involved with activated metals, and the relatively more robust containment. Stakeholder reaction to on-site RH LLW activated metals disposal may be mixed.

\subsubsection{Complexity}

This alternative scenario is more complex than Alternative Scenario 1, but less complex than the other evaluated alternative scenarios. One parallel project must be conducted in addition to the direct work required to implement this alternative scenario: construction of the on-site facility for RH LLW waste. However, disposal on-site is within the control of DOE and is not a complex operation. Costs, schedule, and risks associated with the procurement of new cask systems are completely eliminated in this alternative scenario. Risks of on-site disposal for activated metals using vaults instead of a cell are mitigated by the absence of exposed waste, minimal contamination involved with activated metals, and the relatively more robust containment.

\subsection{Evaluation of Alternative Scenarios}

In this section, the alternative scenarios are ranked from 1 to 4 according to their relative present value cost, risk, and complexity, with one being lowest (see Table 5-4). Present value costs are used in Table 5-4 to compensate for the time value of money in the different scenarios.

Table 5-4. Alternative scenario rankings for cost, risk, and complexity.

\begin{tabular}{|c|c|c|c|c|c|c|}
\hline \multirow[b]{2}{*}{ Alternative Scenario } & \multicolumn{2}{|c|}{ Cost } & \multirow[b]{2}{*}{ Risk } & \multirow[b]{2}{*}{ Complexity } & \multirow[b]{2}{*}{$\begin{array}{c}\text { Numerical } \\
\text { Score }\end{array}$} & \multirow[b]{2}{*}{ Rank } \\
\hline & $\begin{array}{l}\text { Present Value } \\
\text { (Million) }\end{array}$ & Cost & & & & \\
\hline (1) All on-site & $\$ 157$ & 1 & 1 & 1 & 3 & 1 \\
\hline (2) All off-site to NTS & $\$ 378$ & 4 & 3 & 3 & 10 & 3 \\
\hline $\begin{array}{l}\text { (3) } \mathrm{CH}, \mathrm{RH} \text { debris and } \\
\text { resins to NTS; RH metals } \\
\text { to Hanford }\end{array}$ & $\$ 274$ & 3 & 4 & 4 & 11 & 4 \\
\hline $\begin{array}{l}\text { (4) } \mathrm{CH} \text {, RH debris and } \\
\text { resins to NTS; RH metals } \\
\text { on-site }\end{array}$ & $\$ 258$ & 2 & 2 & 2 & 6 & 2 \\
\hline
\end{tabular}

Based upon this ranking, on-site disposal of all LLW is determined to be the preferred scenario. If another alternative scenario is selected, plans for on-site disposal of RH activated metals are recommended as the next most preferable alternative scenario. Shipment of all waste off-site to NTS is ranked third, and splitting waste shipments between NTS and Hanford ranks last. 


\section{SUMMARY AND RECOMMENDATIONS}

This report presents the evaluation of the options for disposal of CH and RH LLW generated by activities on the INL Site after closure of the SDA. The objective of this report is to provide a recommendation on the preferred alternative scenario for future LLW disposal, after systematic consideration of cost, schedule, and risks of the viable options for both off-site and on-site disposal.

Disposal facilities and disposal options that were unable to dispose of portions of the waste due to licensing and WAC considerations were eliminated from further consideration, producing a short list of viable disposal options for the INL Site LLW. These viable options were combined into the four most credible alternative scenarios, each of which accounted for disposal of all INL Site LLW over the period of interest. Section 5 presented the analysis of these four alternative scenarios against the criteria cost, risk, and complexity, and ranked them in order from 1 to 4 for each of the three criteria, one being the most preferred and four being the least preferred. Table 5-4 lists the ranking by individual parameter and total score for each of the four alternative scenarios.

Based on the ranking analysis, the order of recommendation for the four alternative scenarios is:

- $\quad$ Alternative Scenario 1 - Construct a new landfill and RH vault facility and dispose of all LLW on the INL site

- $\quad$ Alternative Scenario 4-Construct a new RH vault facility to dispose of RH LLW activated metals on the INL site and ship all CH LLW, RH debris LLW, and RH resin LLW to NTS for disposal

- $\quad$ Alternative Scenario 2-Ship all LLW to NTS for disposal

- $\quad$ Alternative Scenario 3-Ship all CH LLW, RH debris LLW, and RH resin LLW to NTS for disposal and ship RH LLW activated metals to Hanford for disposal.

Figure 6-1 shows the cost of each of the alternative scenarios by year and contains several features worth noting. The two peaks in Alternative Scenario 1 correspond to the design and construction of the first cell and set of vaults in FY 2009 and to the second cell and set of vaults in FY 2022. In Alternative Scenario 4, the steepest increase in costs is attributable to simultaneous construction of RH LLW vaults and shipments of waste off-site. In Alternative Scenario 3, the largest peak corresponds to design and acquisition, delivery, and acceptance of the truck- and rail-loaded casks. In Alternative Scenario 2, the largest peak comes after the truck-loaded cask has been designed and where the six cask systems are purchased.

Recommendation 1 is the clear selection among the alternative scenarios. This recommendation scored the highest in all categories, having the lowest cost, lowest risk, and being the simplest to implement. Figure 6-1 graphically illustrates the cost advantages of Recommendation 1 as total project costs (rounded to the nearest hundred thousand) over the duration of the project. It shows that building a facility on the INL site for disposal of LLW not only has the lowest total project cost, it has the lowest growth rate, the flattest funding profile, and minimal upfront investment. 


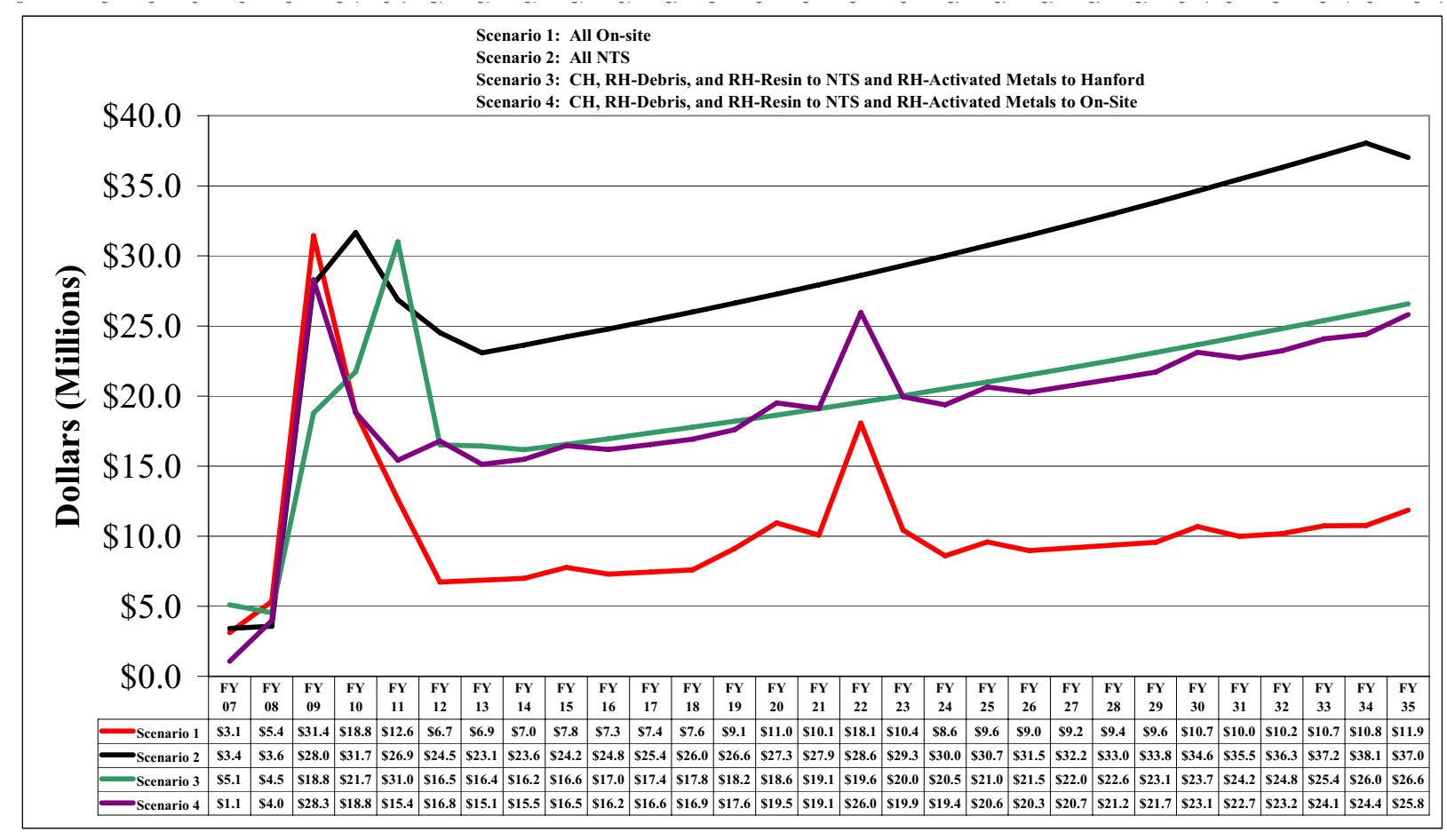

Figure 6-1. Annual project costs by disposal alternative scenario.

As shown in Table 5-4, this alternative scenario also has the lowest net present value. This alternative scenario involves the lowest risk of the four alternatives because it presents no off-site transportation or disposal considerations. In the recommended alternative scenario, the risks are all, at least to some degree, under DOE control. Procurement of casks systems for off-site transportation is eliminated, decreasing cost and schedule risk. Coordination among a series of parallel programs is not required. Dependence on the cooperation of third parties, such as disposal site operators, states other than Idaho, or other federal agencies (e.g., NRC for cask certification), is reduced to the absolute minimum. This is the least complex alternative scenario because just one facility is required to accomplish disposal of all LLW.

Successful implementation of the recommended alternative scenario depends on the availability of $\$ 1.5$ million in operating funds to commence necessary activities in FY 2007. Significant delay in funding could require continual use of the SDA vaults for activated metal disposal, or establishment of on-site storage at a location such as the Intermediate Level Transuranic Storage Facility. 


\section{REFERENCES}

10 CFR 61, 2002, Title 10, "Energy," Part 61, "Licensing Requirements for Land Disposal of Radioactive Waste," Code of Federal Regulations, Office of the Federal Register.

42 USC § 4321 et seq., 1970, "National Environmental Policy Act,” United States Code, January 1, 1970.

42 USC § 6901 et seq., 1976, "Resource Conservation and Recovery Act (Solid Waste Disposal Act)," United States Code, October 21, 1976.

42 USC § 9601 et seq., 1980, "Comprehensive Environmental Response, Compensation and Liability Act of 1980 (CERCLA/Superfund)," United States Code, December 11, 1980.

49 CFR 173, 2002, Title 49, "Transportation," Part 173, "Shippers-General Requirements for Shipments and Packagings," Code of Federal Regulations, Office of the Federal Register.

65 FR 10061, 2000, "Record of Decision for the Department of Energy's Waste Management Program: Treatment and Disposal of Low-Level Waste and Mixed Low-Level Waste; Amendment to the Record of Decision for the Nevada Test Site," Federal Register, U.S. Environmental Protection Agency, February 25, 2000.

DOE, 2000, Final Waste Management Programmatic Environmental Impact Statement for Managing Treatment, Storage, and Disposal of Radioactive and Hazardous Waste, DOE/EIS-200-F, U.S. Department of Energy, Office of Environmental Management, June 1997.

DOE, 2006, Management and Operation of the INL, Contract Number DE-AC07-05ID14517, Modification M041, May 31, 2006.

DOE-ID, 2001, Idaho National Engineering and Environmental Laboratory Reusable Property, Recyclable Materials, and Waste Acceptance Criteria (RRWAC), DOE/ID-10381, Rev. 12, U.S. Department of Energy Idaho Operations Office, Idaho Falls, Idaho.

DOE-NV, 1999, Agreement In Principal Between the Department of Energy and the State of Nevada, DE-GM08-99NV13571, June 1999.

DOE-NV, 2006, Nevada Test Site Waste Acceptance Criteria, DOE-NV-325, Revision 6, U.S. Department of Energy Nevada, October 2003.

DOE O 435.1, 2001, “Radioactive Waste Management,” U.S. Department of Energy, August 28, 2001.

INEEL, 1997, Preliminary Evaluation of Potential Locations at the Idaho National Engineering and Environmental Laboratory for a High-Level Waste Treatment and Interim Storage Facility and a Low-Level Waste Landfill, INEEL/EXT-97-01324, Revision 0, Idaho National Engineering and Environmental Laboratory, Idaho Falls, Idaho, December 1997.

INL, 2006, Preliminary Design of a Future On-Site Low Level Waste Disposal Facility at the INL, Interoffice Memorandum, CCN 206124, July 11, 2006.

INL, 2004, Management and Operation of the Idaho National Laboratory, Contract Number: DE-AC0705ID14517, Idaho Falls, Idaho, November 9, 2004. 
Seattle Post-Intelligencer, 2006, “Judge Strikes Down Hanford Initiative,” Interoffice Memorandum, Preliminary BEA Analysis of Alternative Low-Level Waste Disposal Options, April 2006. 


\section{DEFINITIONS}

$\underline{\text { Term }}$

Activated Metals

Cask

Complexity

Contact-handled LLW

Closure

Curie (Ci)

Disposal

Disposal Alternatives

Disposal, Off-site

Disposal, On-site

\section{Definition}

Structural materials from a nuclear facility that have been subjected to neutron irradiation and contain radionuclide activation products within the matrix of the material.

A container that provides appropriate shielding and structural integrity for the transportation and/or storage of spent fuel and other radioactive materials. The cask serves several functions. It provides chemical, mechanical, thermal and radiological protection, and dissipates decay heat during handling, transport and storage.

As applied to LLW disposal scenarios, complexity refers to the number of disposal sites, parallel construction or procurement projects, and external vendors and agencies that must be coordinated for the overall scenario to achieve all waste management objectives. External refers to organizations other than BEA, INL Site tenants, and DOE.

LLW whose external dose rate is sufficiently low as to not require additional shielding or special handling. Definitions vary among facilities but are usually expressed as a dose rate equivalent at a specific distance from the waste package. This report defines $\mathrm{CH}$ LLW as waste having a dose rate equivalent of less than 200 $\mathrm{mrem} / \mathrm{hr}$ at contact.

Administrative and technical actions taken at a waste disposal facility at the end of its operating lifetime to assure it is left in a state that is protective of human health and the environment.

Non-SI unit of measure of the rate of decay of a radioactive material. One Curie is 37 billion disintegrations per second (Becquerel). (1 $\mathrm{Ci}$ $=3.7 \times 1010 \mathrm{~Bq}$ ) A milliCurie (abbreviated $\mathrm{mCi}$ ) is equal to onethousandth of a Curie.

Emplacement of waste in an appropriate facility without the intention of retrieval.

The various scenarios that were considered for disposal of all LLW from the INL site after the contract mandated deadlines for providing new alternatives. Each alternative scenario consisted of combinations of disposal options, including both on-site and off-site disposal.

Disposal of the LLW or portions thereof at commercial radioactive waste disposal facilities or at DOE managed sites other than the INL.

Disposal of the LLW or portions thereof within the INL site boundary. 
$\underline{\text { Term }}$

Disposal Option

Disposal Scenario

Fissile

Radioactive Waste

Radioactive Waste, Low-Level (LLRW or LLW)

Rem

Remote-Handled (RH) LLW

Risk

Special Nuclear Material (SNM)

\section{Definition}

A possible disposal pathway for one INL LLW waste type to one waste disposal facility to be assessed for costs, schedule, and risks, including transportation and infrastructure changes necessary to dispose of waste by that option.

A combination of Viable Options containing disposition pathways for all INL CH and RH LLW for the entire period of interest.

An isotope that will undergo nuclear fission, i.e. split into two or more lighter materials, upon absorbing a thermal (slow) neutron. The three primary fissile materials are uranium-233, uranium-235, and plutonium-239.

Solid, liquid, and gaseous materials from nuclear operations that are radioactive or become radioactive and for which there is no further use.

LLRW is waste that satisfies the definition of LLRW in the Low-Level Radioactive Waste Policy Amendments Act of 1985. The LLRWPAA defines LLRW as "radioactive material that (A) is not high-level radioactive waste, spent nuclear fuel, or byproduct material as defined in section 11e.2 of the Atomic Energy Act of 1954) and; (B) the Nuclear Regulatory Commission, consistent with existing law and in accordance with paragraph (A), classifies as lowlevel radioactive waste." In a sense, LLRW is defined by what it is not and consequently is the broadest category of waste. It encompasses materials that are slightly above natural radiation background levels to highly radioactive materials which require extreme caution when handling (Greater than Class C - GTCC). Categorization as LLRW does not depend on the level of radioactivity it contains.

Non-SI unit of equivalent dose that measures the effects of ionizing radiation on humans. One rem is equal to 0.01 sievert. A millirem (abbreviated mrem) is equal to one-thousandth of a rem.

LLW that requires special tools, equipment, and procedures for handling to minimize personnel exposure. Definitions vary among facilities but are usually expressed as a dose rate equivalent at a specific distance from the waste package. This report defines RH LLW as waste having a dose rate equivalent of equal to or greater than $200 \mathrm{mrem} / \mathrm{hr}$ at contact.

An analysis of possible events, their probabilities of occurrence, and their potential consequences for the disposal option being evaluated.

Special Nuclear Material is defined in 10 CFR 20.1003 as "(1) Plutonium, uranium-233, uranium enriched in the isotope 233 or in isotope 235 , and any other material that the NRC, pursuant to the 
$\underline{\text { Term }}$

Transuranic Waste

Viable Option

Waste Acceptance Criteria

Waste Inventory

Waste Generator
Definition

provisions of section 51 of the AEA, determines to be SNM, but does not include source material; (2) or any material artificially enriched by any of the foregoing but does not include source material." SNM is important in the fabrication of weapons grade materials and as such has strict licensing and handling controls.

Transuranic waste is radioactive waste containing more than 100 nanocuries (3,700 becquerels) of alpha-emitting transuranic isotopes per gram of waste, with half-lives greater than 20 years, except for:

(1) High-level radioactive waste;

(2) Waste that the Secretary of Energy has determined, with the concurrence of the Administrator of the Environmental Protection Agency, does not need the degree of isolation required by the 40 CFR Part 191 disposal regulations; or

(3) Waste that the Nuclear Regulatory Commission has approved for disposal on a case-by-case basis in accordance with $10 \mathrm{CFR}$ Part 61.

A usable disposal pathway for one INL LLW waste type to one waste disposal facility, including its costs, risks, and availability.

A document that specifies the quantitative or qualitative criteria that must be met for waste to be accepted by the operator of a specific repository for disposal, or by the operator of a storage facility for storage. Waste acceptance requirements might include, for example, restrictions on the radionuclide concentration or the total activity of particular radionuclides (or types of radionuclide) in the waste or requirements concerning the waste form or waste package.

Quantity, radionuclides, activity and waste form characteristics of wastes for which an operator is responsible.

The operating organization of a facility or activity that generates waste. 


\section{Appendix A \\ LLW Disposal Options Task Force}


A-2 


\section{Appendix A}

\section{A-1. LLW Disposal Options Task Force}

The team assembled to address Low Level Waste (LLW) disposal options is depicted in Table A-1. The team composition ensures that all impacted tenants are represented with the appropriate technical expertise to address issues surrounding the long term disposition pathway of Idaho National Laboratory LLW.

Table A-1. LLW Disposal Options Task Force.

\begin{tabular}{|c|c|c|}
\hline Team Member & Company & Tenant \\
\hline Brill, Neil & BBWI & AMWTP \\
\hline Carlson, Timothy & BEA & INL - Team Leader \\
\hline Grant, Roy & BEA & INL \\
\hline Johnson, Dick & BEA & INL (Specific Manufacturing Capability) \\
\hline Mascarenas, Carolyn & BEA & INL \\
\hline O'Rourke, Tim & BEA & INL \\
\hline Rohe, Rhonda & BEA & INL (Advanced Test Reactor) \\
\hline Dixon, Wendy & NR-IBO & NR-IBO \\
\hline Frazier, Jeff & Bettis & NRF \\
\hline Fuller, Paul & Bettis & $\mathrm{NRF}$ \\
\hline Adler-Flitton, Kay & CWI & $\mathrm{ICP}$ \\
\hline Lobdell, Dean & CWI & $\mathrm{ICP}$ \\
\hline Waters, Mary & CWI & ICP (Waste Generator Services) \\
\hline Conner, Julie & DOE & DOE-ID NE \\
\hline Willcox, Mary & DOE & DOE-ID EM \\
\hline Connolly, Joan & North Wind & Support Subcontractor \\
\hline Fisher, Shenean & North Wind & Support Subcontractor \\
\hline Hinman, Peggy & North Wind & Support Subcontractor \\
\hline Marcinkiewicz, Charlie & North Wind & Support Subcontractor \\
\hline
\end{tabular}


The team worked together to address technical issues associated with the selection of disposal options for the disposition of INL LLW. Team members representing waste generating organizations contributed the technical information on waste generation, infrastructure and timeframes associated with disposal needs. Team members conducted research and interviews with INL personnel in order to support issue resolution and discussions at team meetings. Technical experts were also invited to attend the team's regular meetings to provide information on a range of issues related to waste disposal.

The team's efforts entailed discussions with other DOE organizations including Nevada Test Site, Hanford and DOE headquarters (HQ) offices of Environmental Management (EM) and Nuclear Energy (NE). Issues associated with cask development for waste transport, DOE complex-wide waste disposition planning, NEPA coverage of the disposal options investigated were coordinated with DOE HQ to ensure that INL did not pursue options inconsistent with the balance of the DOE complex.

Overall, consensus on each option explored was reached as a team before extensive costs and schedules were developed. 


\section{Appendix B \\ Low-Level Waste \\ Disposal Facility Screening Analysis}


B-2 


\section{CONTENTS}

B-1. INTRODUCTION B-7

B-1.1 Approach and Assumptions B-7

B-1.2 Initial Screening of Low-Level Waste Disposal Facilities B-7

B-1.3 Low-Level Waste Disposal Alternatives B-7

B-1.4 Low-Level Waste Disposal Facilities Comparative Analysis B-8

B-2. REMOTE HANDLED LLW DISPOSAL SCREENING B-8

B-2.1 Debris B-8

B-2.1.1 Debris Disposal Assumptions and Intitial Screening …............................... B-9

B-2.1.2 Disposal of RH LLW Debris at an On-Site Disposal Facility ..................... B-10

B-2.1.3 Disposal of RH LLW Debris at an Off-Site Disposal Facility ...................... B-10

B-2.1.4 Analysis of Viable Disposal Options ..................................................... B-12

B-2.1.5 Comparative Analysis of the Disposal Options ......................................... B-14

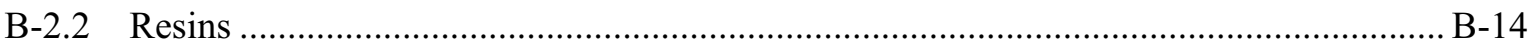

B-2.2.1 Resin Disposal Assumptions and Initial Screening.................................... B-22

B-2.2.2 Disposal of RH LLW Resin at an On-Site Disposal Facility ........................ B-23

B-2.2.3 Disposal of RH LLW Resins at an Off-Site Disposal Facility ..................... B-23

B-2.2.4 Analysis of Viable Disposal Options ................................................... B-25

B-2.2.5 Comparative Analysis of the Disposal Options .......................................... B-27

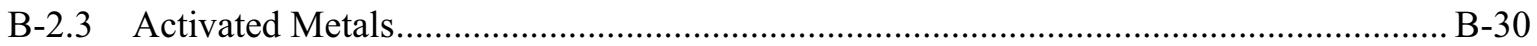

B-2.3.1 Activated Metal Disposal Assumptions and Initial Screening ..................... B-33

B-2.3.2 Disposal of RH LLW activated metal at an On-Site Disposal Facility ......... B-34

B-2.3.3 Disposal of RH LLW Activated Metal at an Off-Site Disposal Facility....... B-35

B-2.3.4 Analysis of Viable Disposal Options ........................................................... B-37

B-2.3.5 Comparative Analysis of the Disposal Options .......................................... B-39

B-3. CONTACT-HANDLED Low-level waste DISPOSAL sCREENING .................................... B-42

B-3.1 Contact-Handled Low-Level Waste …........................................................................ B-42

B-3.1.1 CH LLW Disposal Assumptions and Initial Screening.............................. B-45

B-3.1.2 Disposal of CH LLW at an On Site Disposal Facility ............................... B-45

B-3.1.3 Disposal of CH LLW at an Off-Site Disposal Facility ............................ B-46

B-3.1.4 Analysis of Viable Disposal Options ................................................... B-48

B-3.1.5 Comparative Analysis of the Disposal Options ……................................... B-49

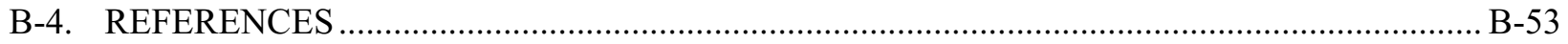




\section{FIGURES}

B-2-1. Remote-handled low-level waste vault disposal forecast

B-34

\section{TABLES}

B-2-1. Summary of remote-handled low-level waste debris (IWTS MP 3597T.R1) ......................... B-9

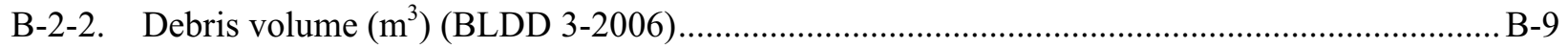

B-2-3. Remote-handled low-level waste debris viable disposal alternatives..................................... B-15

B-2-4. Summary of remote-handled low-level waste Advanced Test Reactor resin

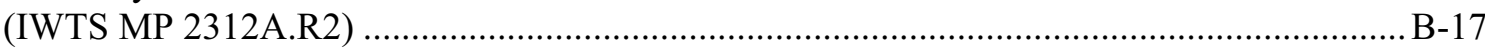

B-2-5. Summary of remote handled low-level waste Naval Reactors Facility resin and

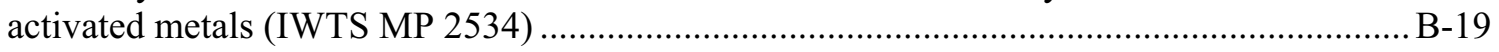

B-2-6. U.S. Ecology disposal costs (based on 2005 rate schedules) vs. Nevada Test Site disposal costs (based on 2006 rate schedules) ...................................................................... B-25

B-2-7. Remote-handled low-level waste resin viable disposal alternatives.................................... B-28

B-2-8. Remote-handled low-level waste Advanced Test Reactor core structural parts..................... B-31

B-2-9. Remote-handled low-level waste Advanced Test Reactor core subassembly parts ................. B-32

B-2-10. Remote-handled low-level waste activated metal disposal alternatives .................................. B-40

B-3-1. Contact-handled low-level waste - Typical Profile \#1 …....................................................... B-43

B-3-2. Contact-Handled low-level waste - Typical Profile \#2 …..................................................... B-44

B-3-3. Estimated disposal rate cost for one year of disposal ..................................................... B-46

B-3-4. Contact-handled low-level waste disposal alternatives ...................................................... B-51 


\section{ACRONYMS}

AMWTP Advanced Mixed Waste Treatment Project

ATR Advanced Test Reactor

BEA Battelle Energy Alliance

CERCLA Comprehensive Environmental Response, Compensation, and Liability Act

CFR Code of Federal Regulations

$\mathrm{CH} \quad$ contact-handled

DOE Department of Energy

DOT Department of Transportation

EIS Environmental Impact Statement

FY fiscal year

GTCC NRC classification - Greater than Class C

ICDF Idaho CERCLA Disposal Facility

INL Idaho National Laboratory

LLW low-level waste

LSA Low Specific Activity

LWBR Light Water Breeder Reactor

MFC Materials and Fuels Complex

NRC Nuclear Regulatory Commission

NRF Naval Reactors Facility

NTS Nevada Test Site

PA performance assessment

RCRA Resource Conservation and Recovery Act

RH remote handled

RTC Reactor Technology Complex

RTP Remote Treatment Project 
RWMC Radioactive Waste Management Complex

SDA Subsurface Disposal Area

TSA-RE Transuranic Storage Area-Retrieval Enclosure

TCLP Toxicity characteristic leaching procedure

WAC Waste Acceptance Criteria

WCF Waste Calciner Filter

WWTF Warm Waste Treatment Facility 


\section{B-1. INTRODUCTION}

This screening analysis was prepared to evaluate the waste disposal options and associated transportation requirements for low-level waste (LLW) generated at the Idaho National Laboratory (INL) Site. The purpose of the screening analysis is to provide disposal information to assist Battelle Energy Alliance (BEA), the primary maintenance and operations contractor, in developing a LLW Disposal Plan. BEA is contractually required to attain, for all INL Site tenants if necessary, off-site disposal capacity by October 1, 2008, for contact-handled (CH) LLW and October 1, 2009, for remote-handled (RH) LLW. For each type of LLW, nine disposal facilities and one newly proposed on-site facility are initially screened to obtain viable disposal options. The viable options are then compared and a recommended preferred option is identified.

\section{B-1.1 Approach and Assumptions}

This evaluation is predicated on current available information and where information gaps exist assumptions were developed. As other information become available, some assumptions may become invalid resulting in the need for re-evaluation of the screening and options analysis as well as the preferred recommendation. Many issues can arise that may affect the transportation or disposal path such as: improved characterization (process knowledge/sample analysis), WAC changes, stakeholder/state interests, judicial determinations, and change in disposal facilities (opening, closing, regulatory restrictions).

\section{B-1.2 Initial Screening of Low-Level Waste Disposal Facilities}

The initial proposed and existing disposal sites are identified and screened for viability. The disposal facilities include both Department of Energy (DOE) and commercial sites. The commercial facilities considered are those in the United States that currently hold or are working on obtaining a Nuclear Regulatory Commission (NRC) license for disposal of radioactive waste. Disposal screening is conducted for CH LLW and for RH LLW. For completeness, on-site disposal options screened in this analysis will include the Radioactive Waste Management Complex (RWMC), the Idaho CERCLA Disposal Facility (ICDF), and a newly proposed LLW disposal facility. Four DOE on-site, three DOE off-site, and four commercial off-site disposal facilities are screened. Typical LLW characteristics are used in the screening of each disposal facility's acceptance criteria, administrative requirements, schedule availability, and transportation options. The most viable disposal option(s) (no more than three) are carried forward to the analysis of options.

\section{B-1.3 Low-Level Waste Disposal Alternatives}

The information provided in this LLW disposal options analysis applies as follows:

- Alternative 1 - Off-Site Disposal of RH LLW

- Alternative 2 - On-Site Disposal of RH LLW

- Alternative 3 - Off-Site Disposal of CH LLW

- Alternative 4 - On-Site Disposal of CH LLW. 


\section{B-1.4 Low-Level Waste Disposal Facilities Comparative Analysis}

this section.

In order to provide information for BEA's LLW Disposal Plan, each viable option is evaluated in

\section{B-2. REMOTE HANDLED LLW DISPOSAL SCREENING}

Alternative 1 and Alternative 2 would include packaging, transportation and disposal of three existing and continuing RH LLW waste types - debris, resins, and activated metals. The assumptions are identified in the following sub-sections to comply with transportation requirements and meet disposal facility WAC for each of the existing RH LLW waste types.

\section{B-2.1 Debris}

RH LLW debris waste consists of materials such as floor sweepings, metallurgical mounts, wooly bags, powder in rags, sludge/powder, rods, pellets and scraps from fabrication of Light Water Breeder Reactor (LWBR) fuel that is currently in storage at RWMC in storage modules and in the Transuranic Storage Area-Retrieval Enclosure (TSA-RE). The waste does not meet the RWMC Waste Acceptance Criteria (WAC) and therefore has been identified for off-site disposal as early as this fiscal year (FY 2006).

The waste was generated during the development of reactor fuels during the 1970s. The Bettis Atomic Power Laboratory under the direction of the Office of Naval Reactors manufactured the ceramic. The fuel pellets were fabricated by compressing intimate mixtures of $\mathrm{UO}_{2}$ and $\mathrm{ThO}_{2}$ powders. The compressed pellets were then sintered. The resultant high-fired pellets have characteristics of a glass in that the material is tightly bonded together in a nearly crystalline form and exhibit conchoidal fracture that is a characteristic of a glass.

All of the rod and pellet material is contained in Department of Transportation (DOT)-2R containers inside 55-gal DOT-6M shipping drums or in 110-gal DOT-6M shipping drums (actual volume is approximately $100 \mathrm{gal}$ ). There are 172 drums that contain $34 \mathrm{~kg}$ of ${ }^{233} \mathrm{U}$ in the form of rod and pellet material. Sixty-five of these drums, containing $16.5 \mathrm{~kg}$, are in shielded overpacks, stored in a Resource Conservation and Recovery Act (RCRA)-approved storage building (WMF-628), and 107 drums, containing $17.5 \mathrm{~kg}$, are under earthen cover at the TSA-RE pad covered by a steel retrieval building (1996). Maximum contact dose (drum) is $250 \mathrm{mR} / \mathrm{hr}$. A summary of the material is in Table B-2-1. The waste from the TSA-RE will be retrieved during the Advanced Mixed Waste Treatment Project's (AMWTP) transuranic waste retrieval process through 2012.

The stored waste can be disposed of once the material profile has been approved at a disposal facility. The disposal schedule is proposed as a basis for evaluating the costs for transportation and disposal costs. If the waste is not accepted at a disposal facility as scheduled, then the waste will continue to be stored until such disposal capability is established. Costs for operating and storage of the waste are not considered although the entire volume of waste projected is included when calculating packaging, transportation, and disposal. The disposal schedule is in Table B-2-2. 
Table B-2-1. Summary of remote-handled low-level waste debris (IWTS MP 3597T.R1).

Characteristics summary of material:

- 1 inch lead cylinder in $2 \mathrm{R}$ in 55-gal drum

- 0.75 inch lead cylinder in 2R in 110-gal drum

- Binary scrap pellets. Material is made of ceramic-based $\mathrm{UO}_{2}$ and $\mathrm{ThO}_{2}$

- Zirconium tube

- Polyvinyl chloride plastic wrapping

- $2 \mathrm{R}$ inner container

- Plywood spacers and Celotex rings in $6 \mathrm{M}$ drum around the $2 \mathrm{R}$ container

\section{Fissile material present:}

Yes

DOT 6M shipping package

Transuranic $<=10 \mathrm{nCi} / \mathrm{g}$

$\begin{array}{ll}\text { Activity: } & \\ { }^{233} \mathrm{U} & 1.698 \mathrm{E}+03 \\ { }^{232} \mathrm{Th} & 5.420 \mathrm{E}+05\end{array}$

Table B-2-2. Debris volume $\left(\mathrm{m}^{3}\right)$ (BLDD 3-2006).

\begin{tabular}{rcccccc}
\hline Fiscal Year & 2007 & 2008 & 2009 & 2010 & 2011 & 2012 \\
\hline Volume $\left(\mathrm{m}^{3}\right)$ & 35.25 & 23 & 23 & 23 & 23 & 23 \\
\hline
\end{tabular}

\section{B-2.1.1 Debris Disposal Assumptions and Intitial Screening}

Assumptions were formulated to permit disposal options analysis. The assumptions are as follows:

- The RH LLW debris, currently packaged in $6 \mathrm{M} / 2 \mathrm{R}$ Type B containers in metal drums will be overpacked in shielded containers/casks for low specific activity (LSA) or Type A shipments. The $6 \mathrm{M} / 2 \mathrm{R}$ Type B containers may not meet DOT requirements at the time of shipment. If the containers can not meet DOT requirements, options include "grandfathering" the packaging into current regulations or obtaining approval for an exception. If none of these options can be used, the drums will need to be opened and the waste repackaged to meet regulatory requirements.

- $\quad$ Type A transport system will be used (shielded truck or shielded boxes).

- $\quad$ The waste packages will be disposed FY 2007-2012.

- $\quad$ AMWTP prepares package and places it on the over-the-road transportation system.

- Radiological characterization information is based on best available information.

- The June 2006 disposal facility WAC are assumed to remain unchanged and provide the criteria governing disposals.

- The waste package will comply with DOT (off-site transport) and transport plan (on-site transport). 


\section{B-2.1.2 Disposal of RH LLW Debris at an On-Site Disposal Facility}

For this alternative, the RH LLW debris would be disposed at an on-site facility. Three on-site disposal options are evaluated to satisfy this alternative.

B-2.1.2.1 Radioactive Waste Management Complex (RWMC). The LLW pit at the RWMC, slated to close to RH LLW at the end of FY 2009, provides the first possible option for on-site disposal for the RH LLW debris. The RH LLW is currently being stored and is therefore available for disposal prior to the RWMC closure. The waste packages have specific components that do not meet the WAC for disposal at the RWMC, specifically; activity exceeds concentration limits for ${ }^{233} \mathrm{U}$ (DOE-ID 2001). Therefore, the RWMC is not considered a viable option and will not be evaluated further.

B-2.1.2.2 Idaho CERCLA Disposal Facility (ICDF). The ICDF is an on-site disposal facility that accepts only Comprehensive Environmental Response, Compensation, and Liability Act (CERCLA) waste generated at the INL (DOE-ID 2005). The RH LLW debris is not a CERCLA generated waste, therefore, the ICDF is not considered a viable option and will not be evaluated further.

B-2.1.2.3 New On-site Disposal Facility. The concept for a new on-site disposal facility accepts all LLW. The RH LLW debris would continue to be stored at the storage modules at the RWMC until the new disposal facility is operational. The waste would be transported via an on-site transport plan. The new on-site LLW disposal facility, although in an early pre-conceptual planning stage, is considered a viable option and will be further evaluated. Depending on the ${ }^{233} \mathrm{U}$ activity level, some of the waste packages may not be suitable for disposal at an on-site facility.

\section{B-2.1.3 Disposal of RH LLW Debris at an Off-Site Disposal Facility}

For this alternative, the RH LLW debris would be disposed at an off-site facility. Eight off-site facilities are evaluated to satisfy this alternative.

B-2.1.3.1 DOE Disposal at Nevada Test Site in Nevada. This option would transport and dispose of the RH LLW debris at Nevada Test Site (NTS). The logistics for moving the RH LLW debris would be to use the existing as-packaged configuration and load the packages into shielded Type A transport boxes or carryalls for shipment to NTS. The transportation support does exist to move the waste package from the INL to NTS. The waste presents a challenge not from the dose at contact (max $250 \mathrm{mR} / \mathrm{hr}$ ) but for meeting the waste acceptance at NTS due to the fissile and the action levels for ${ }^{233} \mathrm{U}$ and ${ }^{232} \mathrm{U}$. As such, a deviation from the NTS WAC may be required for approval of the waste (DOE-NV 2006) and some of the waste packages may not be acceptable for disposal at NTS. Even with the challenges of waste acceptance with a deviation to the NTS WAC, NTS disposal is assumed to be viable and will be evaluated further in the analysis of options section.

B-2.1.3.2 DOE Disposal at Hanford in Washington. This option would transport and dispose of the RH LLW debris at DOE Hanford.

One major unresolved issue complicates disposal at Hanford. The DOE settled their lawsuit with the state of Washington on storing of untreated mixed transuranic waste by agreeing to halt shipments of LLW until a new environmental review is complete. This effectively prohibits the Hanford site from further disposal of out-of-state DOE-generated LLW. The Environmental Impact Statement (EIS) 
currently under development evaluates the impacts of receipt of $62,000 \mathrm{~m}^{3}$ of LLW from off-site. ${ }^{\text {a }}$ A Record of Decision is scheduled to be issued on the EIS in September 2008

The transportation logistics for moving the RH LLW debris would be to use the existing aspackaged configuration and load the packages into shielded Type A transport boxes or carryalls for shipment to Hanford. A special performance assessment (PA) would need to be approved to ensure that there are no unacceptable risks associated with the disposal, particularly with the fissile and radionuclide aspects of the waste. Depending on the ${ }^{233} \mathrm{U}$ activity level, some of the waste packages may not be suitable for disposal at Hanford.

Though the waste appears to meet the initial screening criteria for transporting to and disposal at DOE Hanford (Hanford Site Solid WAC, HNF-EP-0063, Rev. 13) because of the unresolved NEPA issues, Hanford cannot accept any INL LLW until at least FY 2009. This option is considered not to be viable for this waste, as disposal is required as early as FY 2007.

B-2.1.3.3 DOE Disposal at Oak Ridge, Tennessee. The DOE disposal facility in Oak Ridge, Tennessee cannot receive off-site LLW. Therefore, this option is screened out from further evaluation.

B-2.1.3.4 DOE Disposal at Savannah River Site (SRS), South Carolina. The DOE disposal facility in South Carolina includes engineered concrete vaults and trenches. SRS receives only waste from on-site and activated metal components generated by the Navy. Because SRS cannot receive the RH LLW debris, this option is screened out from further evaluation.

B-2.1.3.5 Commercial Disposal at Barnwell, South Carolina. Barnwell, South Carolina is a commercial disposal facility considered as a disposal option. At the beginning of 2008, Barnwell is scheduled to enter into a compact with three Eastern states and at that time, the site will receive waste from only the compact states. The transportation logistics for moving the RH LLW debris would be to use the existing as-packaged configuration and loads the packages into shielded Type A transport boxes or carryalls for shipment to Barnwell. Although cross-country transport is complex, the task could be performed. The RH LLW debris is scheduled for disposal as soon as FY 2007 and from a scheduling basis, Barnwell passes the initial screening. Barnwell's WAC has specific requirements as to the loading of special nuclear material, including ${ }^{233} \mathrm{U}$, such that there must be no more than 100 grams in any single package. The RH LLW debris packages exceed this WAC requirement. To receive the RH LLW debris, the state of South Carolina would have to approve a petition in a timely fashion. The complexity of the cross-country transport, the limited time frame for disposal, and the logistics of waste acceptance with a deviation of the WAC requiring both the disposal facility and the state of South Carolina's approval, this option is screened out from further evaluation.

B-2.1.3.6 Commercial Disposal at U. S. Ecology in Hanford, Washington. This option would transport and dispose of the RH LLW debris at the U.S. Ecology facility in Hanford, Washington.

The transportation logistics for moving the RH LLW debris would be to use the existing aspackaged configuration and load the packages into shielded Type A transport boxes or carryalls for shipment to U.S. Ecology. The U.S. Ecology WAC has specific requirements as to the loading of special nuclear material. Specifically excluded are any packages containing more than 200 grams of ${ }^{233} \mathrm{U}$ in any single package. The RH LLW debris packages exceed this WAC requirement. As the WAC cannot be met, this option is screened out from further evaluation.

\footnotetext{
${ }^{\text {a }}$ Communication with Kay Adler Flitton (CWI) and Michael Collins (DOE-Richland), May 25, 2006.
} 
B-2.1.3.7 Commercial Disposal at Waste Control Specialists in Texas. Waste Control Specialists (WCS), in Texas, is a commercial disposal facility considered as a disposal option. WCS is in the process of applying for a NRC license to accept Class A, B, and C LLW and do not anticipate receiving a license until after 2007. WCS does not have a published WAC so may also have a fissile or special nuclear material limit that would exclude this waste from being accepted. Texas law requires that ownership of the Federal waste portion of the WCS facility revert to the Federal government at the completion of waste receipt operations. DOE has not yet decided whether disposal under these conditions is acceptable, given that DOE might eventually have to take back the site. Therefore, this disposal facility does not have enough information to evaluate and is screened out from further evaluation.

B-2.1.3.8 Commercial Disposal at EnergySolutions in Utah. EnergySolutions (formerly Envirocare of Utah) is a commercial disposal facility considered as a disposal option. EnergySolutions is limited to accepting only NRC Class A waste. EnergySolutions has specific requirements as to the loading of special nuclear material. Specifically excluded are any packages containing more than 200 grams of ${ }^{233} \mathrm{U}$ in any single package. The RH LLW debris packages exceed this requirement. As the WAC cannot be met, this option is screened out from further evaluation.

\section{B-2.1.4 Analysis of Viable Disposal Options}

Both on-site and off-site disposal facilities were initially screened for viability resulting in two potential viable disposal options: a new on-site disposal facility and at NTS.

B-2.1.4.1 Disposal of the RH LLW Debris at New On-Site Disposal Facility. While the concept for a new on-site disposal facility is based on the assumption that all LLW would meet the WAC, a small fraction of the waste packages may not be suitable for on-site disposal. Part of the design considerations for a new RH LLW disposal facility would include the characteristics of the RH LLW debris and the long-term performance and monitoring requirements.

\section{Protectiveness}

This option would be protective of public health, the community, and the environment during continued storage at the RWMC storage modules, transportation to and disposal at a new on-site disposal facility. The waste would not leave the INL or use public highways resulting in the lowest transportation risk with the fewest miles of travel. Adhering to on-site transport plans and meeting the WAC and operational requirements at the new disposal facility will protect worker exposure. This option is protective of the environment, as the disposal facility will be designed to be compliant with all applicable nuclear safety operational and disposal regulations.

\section{Ability to Achieve Objectives}

This option would continue to store the RH LLW debris in a compliant manner until the new disposal facility is operational. As the new facility would specifically incorporate the debris as a wastetype requiring disposal, no special assessments for long-term disposal would need to be completed. This option would achieve the objective for waste disposal.

\section{Technical Feasibility}

RH LLW debris disposal at a new on-site disposal facility is technically feasible. Construction of a new disposal facility would be based on an existing RH LLW disposal facility design and incorporated requirements applicable for the safe disposal of the waste. 


\section{Availability of Equipment, Personnel, and Disposal Facilities}

Transportation methods and disposal of the waste could be handled in a safe and routine manner using equipment, procedures, and personnel available but modified for the new on-site disposal facility. The availability of the disposal facility will be dependent on such details as the location studies, approval processes, construction schedule, and operational readiness reviews.

\section{Administrative Feasibility}

A new on-site disposal facility would incorporate the waste handling, storage, transportation, waste acceptance, disposal, and long-term monitoring for the RH LLW debris. This option is administratively feasible.

\section{B-2.1.4.2 Disposal of the RH LLW Debris at NTS}

\section{Protectiveness}

Disposal of the RH LLW debris at NTS would be protective of public health, the community, and the environment during transportation to and disposal at NTS. This option requires the waste to be transported in compliance with DOT requirements. This option results in the most miles traveled with transport over the public highway system with increases in the associated transportation risks. This option would meet the NTS WAC and is protective of the environment as the disposal facility is compliant with DOE Order 435.1.

\section{Ability to Achieve Objectives}

This option would achieve the objectives for transportation and disposal of the waste package by following DOT regulations and by compliance with the NTS WAC.

\section{Implementation}

Based on the criteria, disposal at NTS is implementable.

\section{Technical Feasibility}

This option is technically feasible. Transportation methods to and disposal of the waste at NTS are currently not routine, but are achievable. The waste would be transported using DOT-compliant packaging. No shipments will involve special DOT permitting.

\section{Availability of Equipment, Personnel, and Disposal Facilities}

The equipment and personnel necessary to complete the transportation and disposal is available. The NTS will continue to be available during the scheduled disposal period.

\section{Administrative Feasibility}

Disposal of the waste at NTS is administratively feasible. The waste is expected to be compliant with the NTS WAC. Packaging and transportation will be compliant with the DOT requirements. The transportation and disposal schedule is complicated by off-site transportation over public highways. 


\section{B-2.1.5 Comparative Analysis of the Disposal Options}

Ten disposal options were initially identified and evaluated to select two viable options. Two viable options were further evaluated for effectiveness, implementability, and costs for analysis of alternatives of the RH LLW debris waste. The option for RH LLW debris disposal at NTS supports Alternative 1 and the option for RH LLW debris disposal at a new on-site disposal facility supports Alternative 2 . The two options, when compared as alternatives, are similar in that each can achieve the disposal objectives for the RH LLW debris waste (see Table B-2-3). Also, the waste is expected to meet the requirements of the WAC at each of the disposal facilities with possibly a deviation required for the off-site disposal option. Both alternatives provide long-term environmental protectiveness and are compliant with DOT requirements or will follow a transport plan.

The differences are:

- Alternative 1 - Off-site Disposal of RH LLW. This alternative incurs more worker and public risk than Alternative 2 due to most travel miles, travel over public highways. This option will require more administrative and scheduling. NTS has less experience receiving RH LLW. This option is technically more complex due to the DOT requirements.

- Alternative 2 - On-site Disposal of RH LLW. This option has the least amount of public risk due to fewest travel miles, fewest number of moves and lifts, and no travel over public highways. This option has the least amount of worker risk because of the fewest travel miles.

\section{B-2.2 Resins}

The Advanced Test Reactor (ATR) at Reactor Technology Complex (RTC) produces ion exchange resins from pool and reactor loop operations. The cation/anion resin beds are used to maintain water purity in the ATR primary coolant system and in waste treatment systems, removing radioactive, particulate and chemical contaminates. Depleted resin beds are replaced upon exhaustion. The spent resin is de-watered, sampled and disposed as non-hazardous radioactive waste. The resins are considered RH LLW in that the contact dose may exceed $200 \mathrm{mR} / \mathrm{hr}$. This is the dose for DOT considerations even though the disposal facilities may have different acceptable values for what is RH LLW. Disposal volume averages approximately $36 \mathrm{~m}^{3} / \mathrm{yr}$ through at least FY 2035 .

Currently, the waste is disposed in the RWMC pit in EPICORETM II liners (about $6 \mathrm{~m}^{3}$ each), see Table B-2-4, and are disposed in the RWMC concrete vaults in 55-Ton Scrap Cask liners. The INL-owned NuPac 14-210L cask is used as a shielded transport. The NuPac 14-210L is a Type A transport and the resins are low specific activity (LSA/II). RTC could continue to use the DOE owned NuPac14-210L for transportation of the resin waste to an acceptable disposal facility.

The Naval Reactors Facility (NRF) produces ion exchange resins from pool operations. The resins are considered RH LLW in that the contact dose may exceed $200 \mathrm{mR} / \mathrm{hr}$. This is the dose for DOT considerations even though the disposal facilities may have different acceptable values for what is RH LLW. Volumes generated average approximately $8 \mathrm{~m}^{3} / \mathrm{yr}$ through at least FY 2035. NRF resins and activated metals have historically shared the same waste stream, see Table B-2-5, and are disposed in the RWMC concrete vaults in 55-Ton Scrap Cask liners. The 55-Ton Scrap Cask is used as a shielded transport. The resins, similar to the ATR resins, could use a Type A transport for shielding such as a commercially available CNS21-300. 
Table B-2-3. Remote-handled low-level waste debris viable disposal alternatives.

\begin{tabular}{|c|c|c|}
\hline & Alternative 1-Disposal at NTS & Alternative 2-New On-site Disposal \\
\hline \multirow{6}{*}{ 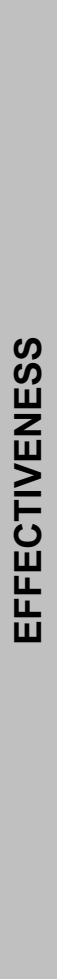 } & \multicolumn{2}{|l|}{ EFFECTIVENESS STATEMENT } \\
\hline & $\begin{array}{l}\text { Can achieve the objectives for transportation and disposal. } \\
\text { Alternative } 1 \text { results in: } \\
\text { - More miles traveled than Alternative } 2 \\
\text { - Includes travel on DOE roads and public highways } \\
\text { - More worker/public exposure than Alternative } 2 \\
\text { - More technical/administrative issues than Alternative } 2 \text {. } \\
\text { However, Alternative } 1 \text { may require a deviation to the WAC } \\
\text { due to fissile material content of the waste. }\end{array}$ & $\begin{array}{l}\text { Can achieve the objectives for transportation and disposal. } \\
\text { Alternative } 2 \text { results in: } \\
\text { - Least number of moves of waste } \\
\text { - Fewest travel miles } \\
\text { - No travel over public highways } \\
\text { - Lowest worker/public exposure } \\
\text { - Minimal technical/administrative issues. }\end{array}$ \\
\hline & \multicolumn{2}{|l|}{ Protectiveness } \\
\hline & $\begin{array}{l}\text { Less protective during transportation and disposal than } \\
\text { Alternative } 2 \text { because: } \\
\text { - More moves and lifts are required } \\
\text { - Greater transport distance is required } \\
\text { - Transport on DOE roadways and public highways } \\
\text { - Exposure to workers and public is potentially greater } \\
\text { because the waste is transported from the INL using road } \\
\text { systems with potential public exposures along the entire } \\
\text { travel route } \\
\text { - Increased mileage increases the risk of potential } \\
\text { accidents. } \\
\text { Environmental risk at each disposal site will be similar since } \\
\text { each facility is approved under DOE O } 435.1 \text {. }\end{array}$ & $\begin{array}{l}\text { More protective during transportation and disposal than Alternative } 1 \\
\text { because: } \\
\text { - Least amount of miles traveled reduces transportation risks } \\
\text { - Due to limited travel miles, least potential environmental risk } \\
\text { - Least exposure potential to the public as the waste does not leave } \\
\text { the INL site } \\
\text { - Exposure to workers is less because the waste does not leave the } \\
\text { INL site, has limited travel distance, and has least number of moves } \\
\text { and lifts. } \\
\text { Environmental risk at each disposal site will be similar since each } \\
\text { facility is approved under DOE O } 435.1 \text {. }\end{array}$ \\
\hline & \multicolumn{2}{|l|}{ Ability to Achieve Transportation and Disposal Objectives } \\
\hline & $\begin{array}{l}\text { Alternatives } 1 \text { and } 2 \text { are capable of meeting transportation } \\
\text { and disposal objectives. }\end{array}$ & $\begin{array}{l}\text { Alternatives } 1 \text { and } 2 \text { are capable of meeting the transportation and } \\
\text { disposal objectives. }\end{array}$ \\
\hline
\end{tabular}


Table B-2-3. (continued).

\begin{tabular}{|c|c|c|}
\hline & Alternative 1-Disposal at NTS & Alternative 2-New On-site Disposal \\
\hline \multirow{10}{*}{ 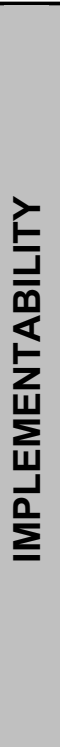 } & \multicolumn{2}{|l|}{ Technical Feasibility } \\
\hline & Technically feasible, but so is Alternatives 2 . & Technically feasible, but so is Alternatives 1. \\
\hline & \multicolumn{2}{|l|}{ Availability of Equipment } \\
\hline & All transport systems available through subcontracts. & All lifting and transport systems available on-site. \\
\hline & \multicolumn{2}{|l|}{ Personnel Services } \\
\hline & $\begin{array}{l}\text { Subcontract personnel and facility personnel with } \\
\text { demonstrated performance will conduct the transportation. } \\
\text { Disposal facility personnel will perform disposal. }\end{array}$ & $\begin{array}{l}\text { Facility personnel with demonstrated performance will conduct } \\
\text { transportation and disposal. }\end{array}$ \\
\hline & \multicolumn{2}{|l|}{ Disposal Facilities } \\
\hline & $\begin{array}{l}\text { More complicated to implement for transportation and } \\
\text { disposal action than Alternative } 2 \text { because: } \\
\text { - Off-site transportation is required, complicating the } \\
\text { planning, approvals, and scheduling } \\
\text { - Transportation includes dedicated transport system } \\
\text { (commercial leases) } \\
\text { - Longer schedule required to complete disposal action } \\
\text { - Least operational experience with RH LLW disposals. }\end{array}$ & $\begin{array}{l}\text { Less complicated to implement for transportation and disposal than } \\
\text { Alternative } 1 \text { because: } \\
\text { - No off-site transportation required simplifying the planning and } \\
\text { scheduling } \\
\text { - Disposal completed in shortest time period } \\
\text { - No leased transport systems required } \\
\text { - Previous operational experience with RH LLW disposals. }\end{array}$ \\
\hline & \multicolumn{2}{|l|}{ Administrative Feasibility } \\
\hline & A WAC deviation may be required. & $\begin{array}{l}\text { Waste is expected to meet new disposal facility WAC requiring no } \\
\text { special PA. }\end{array}$ \\
\hline
\end{tabular}


Table B-2-4. Summary of remote-handled low-level waste Advanced Test Reactor resin (IWTS MP 2312A.R2).

Generating Process Description (Janke 2000):

Depleted ion exchange resins from multiple sources and locations. The TRA-670 and TRA-605 Warm Waste Treatment Facility (WWTF) resin beds are used to clean up radionuclides from various TRA-670 sources and The TRA-605 warm waste feed tank. The sources of the aqueous liquid waste passing through these resins include:

- Low Pressure Demin Water

- ATR-670 Primary Coolant System Tanks/Drains water

- ATR-670 WWTF

- ATR-670 Hot Waste Tank/Drains

- MTR Labs Drains (TRA-605 WWTF only).

Depleted resins may also be from ATR cation/anion primary coolant resin beds used to maintain water purity.

Resins are composed of copolymers of styrene and divinylbenzene formulated for either cation or anion exchange processes. Resins from both WWTF and ATR were analyzed for RCRA metals in 1996 and 1997 and none were found above TCLP limits. The processes and resin types have not changed since those analyses. Based on process knowledge from the generator, the resins may contain up to $5 \%$ water bound to resin surfaces with less than $1 \%$ water as a free liquid in each container.

Depleted resins are discharged to a resin liner to be shipped in a cask to RWMC for disposal.

\section{Fissile material present:}

Yes $->=0.04 \mathrm{~g} / \mathrm{kg}$, waste matrix group is Glass $/$ Slag

Transuranic $<=10 \mathrm{nCi} / \mathrm{g}$

\section{Activity:}

Transuranic Isotope Inventory

Activity Range

$\begin{array}{lllll}\mathrm{Am}-241 & 0 \mathrm{E}+0 & \text { to } & 7.000 \mathrm{E}+00 & \mathrm{nCi} / \mathrm{g} \\ \mathrm{n} m-242 & 0 \mathrm{E}+0 & \text { to } & 3.000 \mathrm{E}-05 & \mathrm{Ci} / \mathrm{m}^{3} \\ \mathrm{Cm}-244 & 0 \mathrm{E}+0 & \text { to } & 4.000 \mathrm{E}+02 & \mathrm{nCi} / \mathrm{g} \\ \mathrm{Np}-238 & 0 \mathrm{E}+0 & \text { to } & 7.420 \mathrm{E}-14 & \mathrm{nCi} / \mathrm{g} \\ \mathrm{Np}-239 & 0 \mathrm{E}+0 & \text { to } & 3.560 \mathrm{E}-10 & \mathrm{nCi} / \mathrm{g} \\ \mathrm{Pu}-238 & 0 \mathrm{E}+0 & \text { to } & 5.000 \mathrm{E}-03 & \mathrm{Ci} / \mathrm{m}^{3} \\ \mathrm{Pu}-239 & 0 \mathrm{E}+0 & \text { to } & 6.000 \mathrm{E}+00 & \mathrm{nCi} / \mathrm{g} \\ \mathrm{Pu}-240 & 0 \mathrm{E}+0 & \text { to } & 6.000 \mathrm{E}+00 & \mathrm{nCi} / \mathrm{g} \\ \mathrm{Pu}-241 & 0 \mathrm{E}+0 & \text { to } & 2.000 \mathrm{E}+00 & \mathrm{nCi} / \mathrm{g}\end{array}$

Expected dose rate:

surface 10 to $5,000 \mathrm{mrem} / \mathrm{hr}$

1-meter: 10-3,500 mrem/hr 
Table B-2-4. (continued).

Other isotopes:

Activity Range

Activity Range

\begin{tabular}{|c|c|c|c|c|c|c|c|c|c|}
\hline $\mathrm{Ag}-110 \mathrm{~m}$ & $0 \mathrm{E}+0$ & to & $3.000 \mathrm{E}-02$ & $\mathrm{Ci} / \mathrm{m} 3$ & Pm-147 & $0 \mathrm{E}+0$ & to & $2.000 \mathrm{E}+00$ & $\mathrm{Ci} / \mathrm{m} 3$ \\
\hline As-76 & $0 \mathrm{E}+0$ & to & $6.500 \mathrm{E}-04$ & $\mathrm{Ci} / \mathrm{m} 3$ & Pm-148 & $0 \mathrm{E}+0$ & to & $7.850 \mathrm{E}-05$ & $\mathrm{nCi} / \mathrm{g}$ \\
\hline Ba-131 & $0 \mathrm{E}+0$ & to & $1.750 \mathrm{E}+03$ & $\mathrm{nCi} / \mathrm{g}$ & Pm-149 & $0 \mathrm{E}+0$ & to & $1.030 \mathrm{E}-14$ & $\mathrm{nCi} / \mathrm{g}$ \\
\hline Ba-133 & $0 \mathrm{E}+0$ & to & $3.000 \mathrm{E}-02$ & $\mathrm{Ci} / \mathrm{m} 3$ & Pr-143 & $0 \mathrm{E}+0$ & to & $1.230 \mathrm{E}+04$ & $\mathrm{nCi} / \mathrm{g}$ \\
\hline Ba-137 & $0 \mathrm{E}+0$ & to & $8.000 \mathrm{E}-08$ & $\mathrm{Ci} / \mathrm{m} 3$ & Pr-144 & $0 \mathrm{E}+0$ & to & $2.000 \mathrm{E}+00$ & $\mathrm{Ci} / \mathrm{m} 3$ \\
\hline Ba-137m & $0 \mathrm{E}+0$ & to & $8.000 \mathrm{E}-02$ & $\mathrm{Ci} / \mathrm{m} 3$ & $\operatorname{Pr}-144 m$ & $0 \mathrm{E}+0$ & to & $4.000 \mathrm{E}-04$ & $\mathrm{Ci} / \mathrm{m} 3$ \\
\hline Ba-140 & $0 \mathrm{E}+0$ & to & $4.500 \mathrm{E}-04$ & $\mathrm{Ci} / \mathrm{m} 3$ & Re-187 & $0 \mathrm{E}+0$ & to & $3.000 \mathrm{E}-02$ & $\mathrm{Ci} / \mathrm{m} 3$ \\
\hline $\mathrm{C}-14$ & $0 \mathrm{E}+0$ & to & $8.000 \mathrm{E}-01$ & $\mathrm{Ci} / \mathrm{m} 3$ & Re-188 & $0 \mathrm{E}+0$ & to & $2.500 \mathrm{E}-02$ & $\mathrm{Ci} / \mathrm{m} 3$ \\
\hline $\mathrm{Ca}-45$ & $0 \mathrm{E}+0$ & to & $7.200 \mathrm{E}-05$ & $\mathrm{Ci} / \mathrm{m} 3$ & $\mathrm{Rh}-103 \mathrm{~m}$ & $0 \mathrm{E}+0$ & to & $1.000 \mathrm{E}-02$ & $\mathrm{Ci} / \mathrm{m} 3$ \\
\hline Cd-109 & $0 \mathrm{E}+0$ & to & $5.500 \mathrm{E}-02$ & $\mathrm{Ci} / \mathrm{m} 3$ & Rh-105 & $0 \mathrm{E}+0$ & to & $9.990 \mathrm{E}+04$ & $\mathrm{nCi} / \mathrm{g}$ \\
\hline Ce-141 & $0 \mathrm{E}+0$ & to & $1.000 \mathrm{E}-01$ & $\mathrm{Ci} / \mathrm{m} 3$ & Rh-106 & $0 \mathrm{E}+0$ & to & $1.500 \mathrm{E}-03$ & $\mathrm{Ci} / \mathrm{m} 3$ \\
\hline Ce-143 & $0 \mathrm{E}+0$ & to & $1.970 \mathrm{E}+04$ & $\mathrm{nCi} / \mathrm{g}$ & Ru-103 & $0 \mathrm{E}+0$ & to & $1.000 \mathrm{E}-02$ & $\mathrm{Ci} / \mathrm{m} 3$ \\
\hline $\mathrm{Ce}-144$ & $0 \mathrm{E}+0$ & to & $5.000 \mathrm{E}-01$ & $\mathrm{Ci} / \mathrm{m} 3$ & Ru-106 & $0 \mathrm{E}+0$ & to & $1.500 \mathrm{E}-03$ & $\mathrm{Ci} / \mathrm{m} 3$ \\
\hline Co-57 & $0 \mathrm{E}+0$ & to & $3.000 \mathrm{E}-02$ & $\mathrm{Ci} / \mathrm{m} 3$ & Sb-122 & $0 \mathrm{E}+0$ & to & $3.000 \mathrm{E}-02$ & $\mathrm{Ci} / \mathrm{m} 3$ \\
\hline Co-58 & $0 \mathrm{E}+0$ & to & $1.500 \mathrm{E}+00$ & $\mathrm{Ci} / \mathrm{m} 3$ & $\mathrm{Sb}-124$ & $0 \mathrm{E}+0$ & to & $9.200 \mathrm{E}-02$ & $\mathrm{Ci} / \mathrm{m} 3$ \\
\hline Co-60 & $0 \mathrm{E}+0$ & to & $5.000 \mathrm{E}+00$ & $\mathrm{Ci} / \mathrm{m} 3$ & $\mathrm{Sb}-125$ & $0 \mathrm{E}+0$ & to & $3.000 \mathrm{E}-02$ & $\mathrm{Ci} / \mathrm{m} 3$ \\
\hline $\mathrm{Cr}-51$ & $0 \mathrm{E}+0$ & to & $6.600 \mathrm{E}+01$ & $\mathrm{Ci} / \mathrm{m} 3$ & Sb-127 & $0 \mathrm{E}+0$ & to & $5.690 \mathrm{E}+02$ & $\mathrm{nCi} / \mathrm{g}$ \\
\hline Cs-134 & $0 \mathrm{E}+0$ & to & $3.000 \mathrm{E}-02$ & $\mathrm{Ci} / \mathrm{m} 3$ & Sc-46 & $0 \mathrm{E}+0$ & to & $3.500 \mathrm{E}-02$ & $\mathrm{Ci} / \mathrm{m} 3$ \\
\hline Cs-136 & $0 \mathrm{E}+0$ & to & $2.000 \mathrm{E}+02$ & $\mathrm{nCi} / \mathrm{g}$ & Se-75 & $0 \mathrm{E}+0$ & to & $1.500 \mathrm{E}-02$ & $\mathrm{Ci} / \mathrm{m} 3$ \\
\hline Cs-137 & $0 \mathrm{E}+0$ & to & $2.000 \mathrm{E}+00$ & $\mathrm{Ci} / \mathrm{m} 3$ & $\mathrm{Si}-32$ & $0 \mathrm{E}+0$ & to & $6.000 \mathrm{E}-10$ & $\mathrm{Ci} / \mathrm{m} 3$ \\
\hline Eu-152 & $0 \mathrm{E}+0$ & to & $7.500 \mathrm{E}-03$ & $\mathrm{Ci} / \mathrm{m} 3$ & Sm-153 & $0 \mathrm{E}+0$ & to & $8.810 \mathrm{E}-16$ & $\mathrm{nCi} / \mathrm{g}$ \\
\hline Eu-154 & $0 \mathrm{E}+0$ & to & $4.200 \mathrm{E}-02$ & $\mathrm{Ci} / \mathrm{m} 3$ & Sn-113 & $0 \mathrm{E}+0$ & to & $3.000 \mathrm{E}-02$ & $\mathrm{Ci} / \mathrm{m} 3$ \\
\hline Eu-155 & $0 \mathrm{E}+0$ & to & $3.000 \mathrm{E}-02$ & $\mathrm{Ci} / \mathrm{m} 3$ & Sn-117m & $0 \mathrm{E}+0$ & to & $4.000 \mathrm{E}-07$ & $\mathrm{Ci} / \mathrm{m} 3$ \\
\hline $\mathrm{Fe}-55$ & $0 \mathrm{E}+0$ & to & $9.600 \mathrm{E}+00$ & $\mathrm{Ci} / \mathrm{m} 3$ & Sn-119m & $0 \mathrm{E}+0$ & to & $3.000 \mathrm{E}-02$ & $\mathrm{Ci} / \mathrm{m} 3$ \\
\hline $\mathrm{Fe}-59$ & $0 \mathrm{E}+0$ & to & $3.000 \mathrm{E}-02$ & $\mathrm{Ci} / \mathrm{m} 3$ & Sn-123 & $0 \mathrm{E}+0$ & to & $1.000 \mathrm{E}-03$ & $\mathrm{Ci} / \mathrm{m} 3$ \\
\hline Gd-153 & $0 \mathrm{E}+0$ & to & $1.000 \mathrm{E}+03$ & $\mathrm{nCi} / \mathrm{g}$ & Sr-89 & $0 \mathrm{E}+0$ & to & $8.200 \mathrm{E}-07$ & $\mathrm{Ci} / \mathrm{m} 3$ \\
\hline $\mathrm{H}-3$ & $0 \mathrm{E}+0$ & to & $5.000 \mathrm{E}-01$ & $\mathrm{Ci} / \mathrm{m} 3$ & Sr-90 & $0 \mathrm{E}+0$ & to & $7.500 \mathrm{E}-01$ & $\mathrm{Ci} / \mathrm{m} 3$ \\
\hline Hf-175 & $0 \mathrm{E}+0$ & to & $4.000 \mathrm{E}+00$ & $\mathrm{Ci} / \mathrm{m} 3$ & Ta-182 & $0 \mathrm{E}+0$ & to & $3.000 \mathrm{E}-02$ & $\mathrm{Ci} / \mathrm{m} 3$ \\
\hline Hf-181 & $0 \mathrm{E}+0$ & to & $3.000 \mathrm{E}+00$ & $\mathrm{Ci} / \mathrm{m} 3$ & Tc-99 & $0 \mathrm{E}+0$ & to & $5.200 \mathrm{E}-02$ & $\mathrm{Ci} / \mathrm{m} 3$ \\
\hline I-129 & $0 \mathrm{E}+0$ & to & $2.000 \mathrm{E}-03$ & $\mathrm{Ci} / \mathrm{m} 3$ & Tc-99m & $0 \mathrm{E}+0$ & to & $9.700 \mathrm{E}-10$ & $\mathrm{nCi} / \mathrm{g}$ \\
\hline $\mathrm{I}-131$ & $0 \mathrm{E}+0$ & to & $3.000 \mathrm{E}-02$ & $\mathrm{Ci} / \mathrm{m} 3$ & $\mathrm{Te}-123 \mathrm{~m}$ & $0 \mathrm{E}+0$ & to & $1.000 \mathrm{E}-07$ & $\mathrm{Ci} / \mathrm{m} 3$ \\
\hline I-132 & $0 \mathrm{E}+0$ & to & $2.000 \mathrm{E}-04$ & $\mathrm{Ci} / \mathrm{m} 3$ & Te- $125 \mathrm{~m}$ & $0 \mathrm{E}+0$ & to & $2.000 \mathrm{E}-03$ & $\mathrm{Ci} / \mathrm{m} 3$ \\
\hline I-133 & $0 \mathrm{E}+0$ & to & $6.800 \mathrm{E}-04$ & $\mathrm{Ci} / \mathrm{m} 3$ & Te-127 & $0 \mathrm{E}+0$ & to & $4.800 \mathrm{E}-10$ & $\mathrm{Ci} / \mathrm{m} 3$ \\
\hline
\end{tabular}


Table B-2-4. (continued).

Other isotopes:

Activity Range

Activity Range

\begin{tabular}{lllll|lllll}
\hline In-113n & 0E +0 & to & $3.000 \mathrm{E}+03$ & $\mathrm{Ci} / \mathrm{m} 3$ & $\mathrm{Te}-127 \mathrm{~m}$ & $0 \mathrm{E}+0$ & to & $5.000 \mathrm{E}-10$ & $\mathrm{Ci} / \mathrm{m} 3$ \\
In-144 & 0E+0 & to & $2.600 \mathrm{E}-06$ & $\mathrm{Ci} / \mathrm{m} 3$ & Te-129 & $0 \mathrm{E}+0$ & to & $2.140 \mathrm{E}+00$ & $\mathrm{nCi} / \mathrm{g}$ \\
In-114m & $0 \mathrm{E}+0$ & to & $2.600 \mathrm{E}-06$ & $\mathrm{Ci} / \mathrm{m} 3$ & $\mathrm{Te}-129 \mathrm{~m}$ & $0 \mathrm{E}+0$ & to & $5.690 \mathrm{E}+02$ & $\mathrm{nCi} / \mathrm{g}$ \\
$\mathrm{La}-140$ & $0 \mathrm{E}+0$ & to & $5.500 \mathrm{E}-03$ & $\mathrm{Ci} / \mathrm{m} 3$ & $\mathrm{Te}-132$ & $0 \mathrm{E}+0$ & to & $5.690 \mathrm{E}+03$ & $\mathrm{nCi} / \mathrm{g}$ \\
$\mathrm{Lu}-177$ & $0 \mathrm{E}+0$ & to & $4.000 \mathrm{E}+03$ & $\mathrm{nCi} / \mathrm{g}$ & $\mathrm{Th}-228$ & $0 \mathrm{E}+0$ & to & $2.500 \mathrm{E}-07$ & $\mathrm{Ci} / \mathrm{m} 3$ \\
$\mathrm{Mn}-54$ & $0 \mathrm{E}+0$ & to & $5.000 \mathrm{E}-01$ & $\mathrm{Ci} / \mathrm{m} 3$ & $\mathrm{U}-237$ & $0 \mathrm{E}+0$ & to & $1.610 \mathrm{E}-10$ & $\mathrm{nCi} / \mathrm{g}$ \\
$\mathrm{Mo}-99$ & $0 \mathrm{E}+0$ & to & $3.000 \mathrm{E}-02$ & $\mathrm{Ci} / \mathrm{m} 3$ & $\mathrm{~W}-187$ & $0 \mathrm{E}+0$ & to & $2.800 \mathrm{E}-02$ & $\mathrm{Ci} / \mathrm{m} 3$ \\
$\mathrm{Nb}-93 \mathrm{~m}$ & $0 \mathrm{E}+0$ & to & $6.300 \mathrm{E}-10$ & $\mathrm{Ci} / \mathrm{m} 3$ & $\mathrm{Xe}-131 \mathrm{~m}$ & $0 \mathrm{E}+0$ & to & $3.000 \mathrm{E}-02$ & $\mathrm{Ci} / \mathrm{m} 3$ \\
$\mathrm{Nb}-94$ & $0 \mathrm{E}+0$ & to & $4.000 \mathrm{E}-02$ & $\mathrm{Ci} / \mathrm{m} 3$ & $\mathrm{Xe}-133$ & $0 \mathrm{E}+0$ & to & $5.690 \mathrm{E}+03$ & $\mathrm{nCi} / \mathrm{g}$ \\
$\mathrm{Nb}-95$ & $0 \mathrm{E}+0$ & to & $3.000 \mathrm{E}-02$ & $\mathrm{Ci} / \mathrm{m} 3$ & $\mathrm{Y}-90$ & $0 \mathrm{E}+0$ & to & $7.500 \mathrm{E}-01$ & $\mathrm{Ci} / \mathrm{m} 3$ \\
$\mathrm{Nb}-95 \mathrm{~m}$ & $0 \mathrm{E}+0$ & to & $1.000 \mathrm{E}-04$ & $\mathrm{Ci} / \mathrm{m} 3$ & $\mathrm{Y}-91$ & $0 \mathrm{E}+0$ & to & $3.000 \mathrm{E}-06$ & $\mathrm{Ci} / \mathrm{m} 3$ \\
$\mathrm{Nd}-147$ & $0 \mathrm{E}+0$ & to & $1.000 \mathrm{E}+03$ & $\mathrm{nCi} / \mathrm{g}$ & $\mathrm{Zn}-65$ & $0 \mathrm{E}+0$ & to & $3.000 \mathrm{E}+00$ & $\mathrm{Ci} / \mathrm{m} 3$ \\
$\mathrm{Ni}-59$ & $0 \mathrm{E}+0$ & to & $4.000 \mathrm{E}-02$ & $\mathrm{Ci} / \mathrm{m} 3$ & $\mathrm{Zr}-93$ & $0 \mathrm{E}+0$ & to & $3.000 \mathrm{E}-08$ & $\mathrm{Ci} / \mathrm{m} 3$ \\
$\mathrm{Ni}-63$ & $0 \mathrm{E}+0$ & to & $2.000 \mathrm{E}+00$ & $\mathrm{Ci} / \mathrm{m} 3$ & $\mathrm{Zr}-95$ & $0 \mathrm{E}+0$ & to & $1.000 \mathrm{E}-01$ & $\mathrm{Ci} / \mathrm{m} 3$ \\
$\mathrm{P}-32$ & $0 \mathrm{E}+0$ & to & $1.500 \mathrm{E}-09$ & $\mathrm{Ci} / \mathrm{m} 3$ & $\mathrm{Zr}-97$ & $0 \mathrm{E}+0$ & to & $1.860 \mathrm{E}-40$ & $\mathrm{nCi} / \mathrm{g}$ \\
\hline
\end{tabular}

Table B-2-5. Summary of remote handled low-level waste Naval Reactors Facility resin and activated metals (IWTS MP 2534).

Fissile material present:

Yes $->=0.04 \mathrm{~g} / \mathrm{kg}$, waste matrix group is SALT

Transuranic $<=10 \mathrm{nCi} / \mathrm{g}$

Transuranic isotope inventory:

Activity Range

$\begin{array}{lllll}\text { Am-241 } & 3.291 \mathrm{E}-03 & \text { to } & 2000 \mathrm{E}-01 & \mathrm{nCi} / \mathrm{g} \\ \mathrm{Am}-242 & 0 \mathrm{E}+0 & \text { to } & 1.441 \mathrm{E}-07 & \mathrm{nCi} / \mathrm{g} \\ \mathrm{Am}-242 \mathrm{~m} & 0 \mathrm{E}+0 & \text { to } & 1.704 \mathrm{E}-05 & \mathrm{nCi} / \mathrm{g} \\ \mathrm{Am}-243 & 0 \mathrm{E}+0 & \text { to } & 1.846 \mathrm{E}-04 & \mathrm{nCi} / \mathrm{g} \\ \mathrm{Cm}-242 & 0 \mathrm{E}+0 & \text { to } & 4.362 \mathrm{E}-01 & \mathrm{Ci} / \mathrm{m} 3 \\ \mathrm{Cm}-243 & 0 \mathrm{E}+0 & \text { to } & 2.594 \mathrm{E}-04 & \mathrm{Ci} / \mathrm{m} 3 \\ \mathrm{Cm}-244 & 0 \mathrm{E}+0 & \text { to } & 6.115 \mathrm{E}-03 & \mathrm{nCi} / \mathrm{g} \\ \mathrm{Np}-239 & 0 \mathrm{E}+0 & \text { to } & 1.569 \mathrm{E}-06 & \mathrm{Ci} / \mathrm{m} 3 \\ \mathrm{Pu}-238 & 9.265 \mathrm{E}-04 & \text { to } & 5.000 \mathrm{E}+00 & \mathrm{Ci} / \mathrm{m} 3 \\ \mathrm{Pu}-239 & 1.696 \mathrm{E}-01 & \text { to } & 5.250 \mathrm{E}-01 & \mathrm{nCi} / \mathrm{g} \\ \mathrm{Pu}-240 & 1.100 \mathrm{E}-02 & \text { to } & 5.253 \mathrm{E}-02 & \mathrm{nCi} / \mathrm{g} \\ \mathrm{Pu}-241 & 1.557 \mathrm{E}-01 & \text { to } & 8.023 \mathrm{E}+00 & \mathrm{nCi} / \mathrm{g}\end{array}$


Table B-2-5. (continued).

U-233 and U-235 isotope inventory:

Activity Range

U-233 6.770E-04 to $1.610 \mathrm{E}-03 \quad \mathrm{nCi} / \mathrm{g}$

Expected dose rate:

Surface: 40,000 to $27,500,000 \mathrm{mrem} / \mathrm{hr}$

1-meter: 1,000 to $50,000 \mathrm{mrem} / \mathrm{hr}$

Other isotopes:

Activity Range

Activity Range

\begin{tabular}{|c|c|c|c|c|c|c|c|c|c|}
\hline Ag-108 & $5.258 \mathrm{E}-06$ & to & $2.167 \mathrm{E}-04$ & $\mathrm{Ci} / \mathrm{m}^{3}$ & $\mathrm{~Pb}-212$ & $0 \mathrm{E}+0$ & to & $4.275 \mathrm{E}-06$ & $\mathrm{Ci} / \mathrm{m}^{3}$ \\
\hline Ag- $108 \mathrm{~m}$ & $5.908 \mathrm{E}-05$ & to & $2.455 \mathrm{E}-03$ & $\mathrm{Ci} / \mathrm{m}^{3}$ & Pm-147 & 4.905E-05 & to & $1.503 \mathrm{E}-01$ & $\mathrm{Ci} / \mathrm{m}^{3}$ \\
\hline $\mathrm{Ag}-109 \mathrm{~m}$ & $1.505 \mathrm{E}-08$ & to & $1.462 \mathrm{E}-07$ & $\mathrm{Ci} / \mathrm{m}^{3}$ & Pm-148m & $0 \mathrm{E}+0$ & to & $7.395 \mathrm{E}-06$ & $\mathrm{Ci} / \mathrm{m}^{3}$ \\
\hline Ag-110 & $2.086 \mathrm{E}-07$ & to & $3.219 \mathrm{E}-03$ & $\mathrm{Ci} / \mathrm{m}^{3}$ & Po-210 & $0 \mathrm{E}+0$ & to & $1.319 \mathrm{E}-04$ & $\mathrm{Ci} / \mathrm{m}^{3}$ \\
\hline $\mathrm{Ag}-110 \mathrm{~m}$ & $1.568 \mathrm{E}-05$ & to & $1.932 \mathrm{E}-04$ & $\mathrm{Ci} / \mathrm{m}^{3}$ & Po-212 & $0 \mathrm{E}+0$ & to & $2.740 \mathrm{E}-06$ & $\mathrm{Ci} / \mathrm{m}^{3}$ \\
\hline Ar-37 & $0 \mathrm{E}+0$ & to & $4.169 \mathrm{E}-06$ & $\mathrm{Ci} / \mathrm{m}^{3}$ & Po-216 & $0 \mathrm{E}+0$ & to & $4.275 \mathrm{E}-06$ & $\mathrm{Ci} / \mathrm{m}^{3}$ \\
\hline Ar-39 & $3.317 \mathrm{E}-05$ & to & $2.198 \mathrm{E}-03$ & $\mathrm{Ci} / \mathrm{m}^{3}$ & $\operatorname{Pr}-144$ & $1.118 \mathrm{E}-06$ & to & $5.592 \mathrm{E}-02$ & $\mathrm{Ci} / \mathrm{m}^{3}$ \\
\hline Ba-133 & $2.990 \mathrm{E}-08$ & to & $3.654 \mathrm{E}-06$ & $\mathrm{Ci} / \mathrm{m}^{3}$ & Pr-144m & $2.027 \mathrm{E}-08$ & to & $7.706 \mathrm{E}-04$ & $\mathrm{Ci} / \mathrm{m}^{3}$ \\
\hline $\mathrm{Ba}-137 \mathrm{~m}$ & $2.403 \mathrm{E}-04$ & to & $2.388 \mathrm{E}+01$ & $\mathrm{Ci} / \mathrm{m}^{3}$ & $\mathrm{Ra}-224$ & $0 \mathrm{E}+0$ & to & $4.275 \mathrm{E}-06$ & $\mathrm{Ci} / \mathrm{m}^{3}$ \\
\hline Be-10 & $1.614 \mathrm{E}-07$ & to & $1.0635 \mathrm{E}-05$ & $\mathrm{Ci} / \mathrm{m}^{3}$ & $\mathrm{Rb}-87$ & $4.096 \mathrm{E}-08$ & to & $2.975 \mathrm{E}-06$ & $\mathrm{Ci} / \mathrm{m}^{3}$ \\
\hline Bi-212 & $0 \mathrm{E}+0$ & to & $4.275 \mathrm{E}-06$ & $\mathrm{Ci} / \mathrm{m}^{3}$ & Re-188 & $0 \mathrm{E}+0$ & to & $8.959 \mathrm{E}-03$ & $\mathrm{Ci} / \mathrm{m}^{3}$ \\
\hline C-14 & $4.816 \mathrm{E}-03$ & to & $5.000 \mathrm{E}+00$ & $\mathrm{Ci} / \mathrm{m}^{3}$ & Rh-103m & $0 \mathrm{E}+0$ & to & $3.837 \mathrm{E}-04$ & $\mathrm{Ci} / \mathrm{m}^{3}$ \\
\hline $\mathrm{Ca}-45$ & $6.320 \mathrm{E}-09$ & to & $2.838 \mathrm{E}-03$ & $\mathrm{Ci} / \mathrm{m}^{3}$ & Rh-106 & $0 \mathrm{E}+0$ & to & $1.500 \mathrm{E}-03$ & $\mathrm{Ci} / \mathrm{m}^{3}$ \\
\hline Cd-109 & $1.505 \mathrm{E}-08$ & to & $5.666 \mathrm{E}-02$ & $\mathrm{Ci} / \mathrm{m}^{3}$ & Rn-220 & $0 \mathrm{E}+0$ & to & $4.275 \mathrm{E}-06$ & $\mathrm{Ci} / \mathrm{m}^{3}$ \\
\hline Cd-113m & $3.743 \mathrm{E}-08$ & to & $1.151 \mathrm{E}-05$ & $\mathrm{Ci} / \mathrm{m}^{3}$ & $\mathrm{Ru}-103$ & $0 \mathrm{E}+0$ & to & $3.837 \mathrm{E}-04$ & $\mathrm{Ci} / \mathrm{m}^{3}$ \\
\hline Cd- $115 \mathrm{~m}$ & $0 \mathrm{E}+0$ & to & $8.479 \mathrm{E}-07$ & $\mathrm{Ci} / \mathrm{m}^{3}$ & Ru-106 & $2.437 \mathrm{E}-06$ & to & $5.118 \mathrm{E}-02$ & $\mathrm{Ci} / \mathrm{m}^{3}$ \\
\hline $\mathrm{Ce}-141$ & $0 \mathrm{E}+0$ & to & $6.132 \mathrm{E}-05$ & $\mathrm{Ci} / \mathrm{m}^{3}$ & S-35 & $0 \mathrm{E}+0$ & to & $1.172 \mathrm{E}-01$ & $\mathrm{Ci} / \mathrm{m}^{3}$ \\
\hline $\mathrm{Ce}-144$ & $1.139 \mathrm{E}-06$ & to & $5.592 \mathrm{E}-02$ & $\mathrm{Ci} / \mathrm{m}^{3}$ & $\mathrm{Sb}-124$ & $0 \mathrm{E}+0$ & to & $6.220 \mathrm{E}-02$ & $\mathrm{Ci} / \mathrm{m}^{3}$ \\
\hline $\mathrm{Cl}-36$ & $1.349 \mathrm{E}-04$ & to & $5.066 \mathrm{E}-03$ & $\mathrm{Ci} / \mathrm{m}^{3}$ & Sb-125 & 3.639E-01 & to & $5.780 \mathrm{E}+01$ & $\mathrm{Ci} / \mathrm{m}^{3}$ \\
\hline Co-57 & $0 \mathrm{E}+0$ & to & $3.865 \mathrm{E}-02$ & $\mathrm{Ci} / \mathrm{m}^{3}$ & Sc-46 & $0 \mathrm{E}+0$ & to & $7.205 \mathrm{E}-03$ & $\mathrm{Ci} / \mathrm{m}^{3}$ \\
\hline Co-58 & $5.631 \mathrm{E}-10$ & to & $4.014 \mathrm{E}+01$ & $\mathrm{Ci} / \mathrm{m}^{3}$ & Se-75 & $0 \mathrm{E}+0$ & to & $4.642 \mathrm{E}-03$ & $\mathrm{Ci} / \mathrm{m}^{3}$ \\
\hline Co-60 & $1.364 \mathrm{E}+01$ & to & $1.000 \mathrm{E}+04$ & $\mathrm{Ci} / \mathrm{m}^{3}$ & Se-79 & $3.569 \mathrm{E}-10$ & to & $2.975 \mathrm{E}-06$ & $\mathrm{Ci} / \mathrm{m}^{3}$ \\
\hline Cr-51 & $0 \mathrm{E}+0$ & to & $1.167 \mathrm{E}+00$ & $\mathrm{Ci} / \mathrm{m}^{3}$ & Sm-145 & $5.626 \mathrm{E}-07$ & to & $3.086 \mathrm{E}-03$ & $\mathrm{Ci} / \mathrm{m}^{3}$ \\
\hline Cs-134 & $6.835 \mathrm{E}-04$ & to & $1.807 \mathrm{E}-01$ & $\mathrm{Ci} / \mathrm{m}^{3}$ & Sm-151 & $2.456 \mathrm{E}-03$ & to & $3.282 \mathrm{E}+01$ & $\mathrm{Ci} / \mathrm{m}^{3}$ \\
\hline Cs-137 & $2.540 \mathrm{E}-04$ & to & $3.000 \mathrm{E}-01$ & $\mathrm{Ci} / \mathrm{m}^{3}$ & Sn-113 & $1.821 \mathrm{E}-07$ & to & $4.328 \mathrm{E}+00$ & $\mathrm{Ci} / \mathrm{m}^{3}$ \\
\hline
\end{tabular}


Table B-2-5. (continued).

\begin{tabular}{|c|c|c|c|c|c|c|c|c|c|}
\hline \multirow[b]{2}{*}{ Eu-152 } & \multicolumn{3}{|c|}{ Activity Range } & \multicolumn{6}{|c|}{ Activity Range } \\
\hline & $8.829 \mathrm{E}-05$ & to & $2.050 \mathrm{E}-01$ & $\mathrm{Ci} / \mathrm{m}^{3}$ & Sn-119m & $1.253 \mathrm{E}-02$ & to & $7.886 \mathrm{E}+01$ & $\mathrm{Ci} / \mathrm{m}^{3}$ \\
\hline Eu-154 & $3.533 \mathrm{E}-02$ & to & $90909 \mathrm{E}+00$ & $\mathrm{Ci} / \mathrm{m}^{3}$ & Sn-121m & $2.534 \mathrm{E}-04$ & to & $1.516 \mathrm{E}-01$ & $\mathrm{Ci} / \mathrm{m}^{3}$ \\
\hline Eu-155 & $9.940 \mathrm{E}-03$ & to & $3.458 \mathrm{E}+00$ & $\mathrm{Ci} / \mathrm{m}^{3}$ & Sn-123 & $2.286 \mathrm{E}-09$ & to & $1.362 \mathrm{E}-02$ & $\mathrm{Ci} / \mathrm{m}^{3}$ \\
\hline $\mathrm{Fe}-55$ & $4.090 \mathrm{E}+00$ & to & $3.850 \mathrm{E}+03$ & $\mathrm{Ci} / \mathrm{m}^{3}$ & Sr- 85 & $0 \mathrm{E}+0$ & to & $9.640 \mathrm{E}-05$ & $\mathrm{Ci} / \mathrm{m}^{3}$ \\
\hline $\mathrm{Fe}-59$ & $0 \mathrm{E}+0$ & to & 2.313E-01 & $\mathrm{Ci} / \mathrm{m}^{3}$ & Sr-89 & $0 \mathrm{E}+0$ & to & $2.073 \mathrm{E}-02$ & $\mathrm{Ci} / \mathrm{m}^{3}$ \\
\hline Gd-153 & $0 \mathrm{E}+0$ & to & $1.4943 \mathrm{E}-03$ & $\mathrm{Ci} / \mathrm{m}^{3}$ & Sr-90 & $1.845 \mathrm{E}-04$ & to & $5.000 \mathrm{E}+00$ & $\mathrm{Ci} / \mathrm{m}^{3}$ \\
\hline $\mathrm{H}-3$ & $1.241 \mathrm{E}-02$ & to & $5.000 \mathrm{E}+00$ & $\mathrm{Ci} / \mathrm{m}^{3}$ & Тa-182 & $5.838 \mathrm{E}-06$ & to & $1.196 \mathrm{E}+02$ & $\mathrm{Ci} / \mathrm{m}^{3}$ \\
\hline Hf-175 & $0 \mathrm{E}+0$ & to & $5.916 \mathrm{E}-02$ & $\mathrm{Ci} / \mathrm{m}^{3}$ & Tb-160 & $0 \mathrm{E}+0$ & to & $1.614 \mathrm{E}-06$ & $\mathrm{Ci} / \mathrm{m}^{3}$ \\
\hline Hf-181 & $0 \mathrm{E}+0$ & to & $9.591 \mathrm{E}-02$ & $\mathrm{Ci} / \mathrm{m}^{3}$ & Tc-99 & $7.466 \mathrm{E}-06$ & to & $6.000 \mathrm{E}-03$ & $\mathrm{Ci} / \mathrm{m}^{3}$ \\
\hline $\mathrm{Hg}-203$ & $0 \mathrm{E}+0$ & to & $1.586 \mathrm{E}-06$ & $\mathrm{Ci} / \mathrm{m}^{3}$ & Te-123m & $0 \mathrm{E}+0$ & to & 8.257E-03 & $\mathrm{Ci} / \mathrm{m}^{3}$ \\
\hline I-129 & $1.204 \mathrm{E}-10$ & to & $7.000 \mathrm{E}-07$ & $\mathrm{Ci} / \mathrm{m}^{3}$ & Te-125m & 8.297E-02 & to & $1.323 \mathrm{E}+01$ & $\mathrm{Ci} / \mathrm{m}^{3}$ \\
\hline In-113m & $1.821 \mathrm{E}-07$ & to & $4.327 \mathrm{E}+00$ & $\mathrm{Ci} / \mathrm{m}^{3}$ & Te-127m & $0 \mathrm{E}+0$ & to & 2.085R-04 & $\mathrm{Ci} / \mathrm{m}^{3}$ \\
\hline In-144 & $0 \mathrm{E}+0$ & to & $1.080 \mathrm{E}-02$ & $\mathrm{Ci} / \mathrm{m}^{3}$ & Te-129 & $0 \mathrm{E}+0$ & to & $3.280 \mathrm{E}-06$ & $\mathrm{Ci} / \mathrm{m}^{3}$ \\
\hline In-114m & $0 \mathrm{E}+0$ & to & $1.129 \mathrm{E}-02$ & $\mathrm{Ci} / \mathrm{m}^{3}$ & Te-129m & $0 \mathrm{E}+0$ & to & 4.275E-06 & $\mathrm{Ci} / \mathrm{m}^{3}$ \\
\hline Ir-192 & $8.190 \mathrm{E}-13$ & to & $2.480 \mathrm{E}-02$ & $\mathrm{Ci} / \mathrm{m}^{3}$ & Th-228 & $0 \mathrm{E}+0$ & to & $4.275 \mathrm{E}-06$ & $\mathrm{Ci} / \mathrm{m}^{3}$ \\
\hline Kr-85 & $1.284 \mathrm{E}-05$ & to & $2.451 \mathrm{E}-02$ & $\mathrm{Ci} / \mathrm{m}^{3}$ & Th-234 & $0 \mathrm{E}+0$ & to & $4.420 \mathrm{E}-06$ & $\mathrm{Ci} / \mathrm{m}^{3}$ \\
\hline Lu-177 & $0 \mathrm{E}+0$ & to & $1.426 \mathrm{E}-05$ & $\mathrm{Ci} / \mathrm{m}^{3}$ & Tl-208 & $0 \mathrm{E}+0$ & to & $1.536 \mathrm{E}-06$ & $\mathrm{Ci} / \mathrm{m}^{3}$ \\
\hline Mn-54 & $2.041 \mathrm{E}-03$ & to & $9.972 \mathrm{E}+00$ & $\mathrm{Ci} / \mathrm{m}^{3}$ & U-232 & $0 \mathrm{E}+0$ & to & $5.369 \mathrm{E}-06$ & $\mathrm{Ci} / \mathrm{m}^{3}$ \\
\hline Mo-93 & $2.359 \mathrm{E}-05$ & to & $1.360 \mathrm{E}-02$ & $\mathrm{Ci} / \mathrm{m}^{3}$ & U-234 & $0 \mathrm{E}+0$ & to & 4.419E-06 & $\mathrm{Ci} / \mathrm{m}^{3}$ \\
\hline $\mathrm{Nb}-93 \mathrm{~m}$ & $1.408 \mathrm{E}-02$ & to & $2.379 \mathrm{E}+00$ & $\mathrm{Ci} / \mathrm{m}^{3}$ & U-237 & $0 \mathrm{E}+0$ & to & $2.335 \mathrm{E}-06$ & $\mathrm{Ci} / \mathrm{m}^{3}$ \\
\hline $\mathrm{Nb}-94$ & $8.995 \mathrm{E}-04$ & to & $2.000 \mathrm{E}+00$ & $\mathrm{Ci} / \mathrm{m}^{3}$ & $\mathrm{U}-238$ & $0 \mathrm{E}+0$ & to & 4.419E-06 & $\mathrm{Ci} / \mathrm{m}^{3}$ \\
\hline $\mathrm{Nb}-95$ & $2.990 \mathrm{E}-11$ & to & $4.875 \mathrm{E}+01$ & $\mathrm{Ci} / \mathrm{m}^{3}$ & W-181 & $1.539 \mathrm{E}-09$ & to & $2.669 \mathrm{E}-02$ & $\mathrm{Ci} / \mathrm{m}^{3}$ \\
\hline $\mathrm{Nb}-95 \mathrm{~m}$ & $0 \mathrm{E}+0$ & to & 4.761E-01 & $\mathrm{Ci} / \mathrm{m}^{3}$ & W-185 & $0 \mathrm{E}+0$ & to & $1.301 \mathrm{E}-01$ & $\mathrm{Ci} / \mathrm{m}^{3}$ \\
\hline $\mathrm{Ni}-59$ & $5.057 \mathrm{E}-01$ & to & $5.000 \mathrm{E}+02$ & $\mathrm{Ci} / \mathrm{m}^{3}$ & Y-90 & $1.845 \mathrm{E}-04$ & to & $5.000 \mathrm{E}+00$ & $\mathrm{Ci} / \mathrm{m}^{3}$ \\
\hline $\mathrm{Ni}-63$ & $5.707 \mathrm{E}+01$ & to & $5.500 \mathrm{E}+04$ & $\mathrm{Ci} / \mathrm{m}^{3}$ & Y-91 & $0 \mathrm{E}+0$ & to & $1.078 \mathrm{E}-01$ & $\mathrm{Ci} / \mathrm{m}^{3}$ \\
\hline Os-185 & $0 \mathrm{E}+0$ & to & $5.888 \mathrm{E}-05$ & $\mathrm{Ci} / \mathrm{m}^{3}$ & Zn-65 & $1.301 \mathrm{E}-06$ & to & $3.908 \mathrm{E}-02$ & $\mathrm{Ci} / \mathrm{m}^{3}$ \\
\hline P-33 & $0 \mathrm{E}+0$ & to & $2.621 \mathrm{E}-04$ & $\mathrm{Ci} / \mathrm{m}^{3}$ & Zr-93 & $6.919 \mathrm{E}-04$ & to & $3.231 \mathrm{E}-02$ & $\mathrm{Ci} / \mathrm{m}^{3}$ \\
\hline $\mathrm{Pa}-233$ & $0 \mathrm{E}+0$ & to & 9.849E-06 & $\mathrm{Ci} / \mathrm{m}^{3}$ & Zr-95 & $0 \mathrm{E}+0$ & to & $2.268 \mathrm{E}+01$ & $\mathrm{Ci} / \mathrm{m}^{3}$ \\
\hline $\mathrm{Pa}-234 \mathrm{~m}$ & $0 \mathrm{E}+0$ & to & $4.420 \mathrm{E}-06$ & $\mathrm{Ci} / \mathrm{m}^{3}$ & & & & & \\
\hline
\end{tabular}




\section{B-2.2.1 Resin Disposal Assumptions and Initial Screening}

Assumptions were formulated to permit disposal options analysis. The assumptions are as follows for the ATR resins:

- The ATR resins, currently packaged in EPICORETM II liners (approximately $6 \mathrm{~m}^{3}$ each), will be the waste package with the NuPac $14210 \mathrm{~L}$ cask being used to transport the waste package.

- The INL-owned 55-ton scrap cask will be used onsite for NRF resins. For offsite, a shielded DOT approved transport system will be used.

- The resins will be shipped as LSA/II.

Note: The ATR resin must meet LSA requirements in order to use the NuPac 14-210L cask for resin shipment off-site. The LSA requirements include curie concentration limits and radiation level requirements. During routine shipments, ATR resin falls well below the LSA limits for radioactivity content and radiation level. If resin exceeds the LSA criteria during an off-normal event, this cask could not be shipped off-site in accordance with DOT regulations. Casks meeting Type B packaging would be required. The Type B cask suitable for this purpose has not been identified.

- $\quad$ The waste packages will be disposed FY 2010-2035.

- Radiological characterization information is based on best available information.

- The June 2006 disposal facility WACs are assumed to remain unchanged and provide the criteria governing disposals.

- The waste package will comply with DOT (off-site transport) and transport plan (on-site transport).

Assumptions were formulated to permit disposal options analysis. The assumptions are as follows for the NRF resins:

- The NRF resins, currently packaged in 55-Ton Scrap Cask liners (approximately $3 \mathrm{~m}^{3}$ each), will be the waste package.

- The INL-owned 55-Ton Scrap Cask will be used (for shielding) on-site only. For off-site, the ATR liner and cask system will be used.

- $\quad$ The resins will be shipped as LSA/II.

- $\quad$ Eight $\mathrm{m}^{3}$ of resins are generated each year by NRF.

- $\quad$ The waste packages will be disposed FY 2010-2035.

- Radiological characterization information is based on best available information.

- The June 2006 disposal facility WACs are assumed to remain unchanged and provide the criteria governing disposals.

- $\quad$ The waste package will comply with DOT (off-site transport) and transport plan (on-site transport). 


\section{B-2.2.2 Disposal of RH LLW Resin at an On-Site Disposal Facility}

For this alternative, the RH LLW resins would be disposed at an on-site facility. Three on-site disposal options are evaluated to satisfy this alternative.

B-2.2.2.1 Radioactive Waste Management Complex (RWMC). Demineralizer resins, both from RTC and NRF, are currently disposed at the RWMC. The RTC resins use the NuPac 14-210L cask and liner system and are disposed in the bulk pit. The NRF resins use the 55-ton scrap cask and liner system and are disposed in the concrete vaults. Disposal at the RWMC is anticipated through at least FY 2009 although the pit may be volumetrically filled or close sooner at the end of FY 2008. For this analysis, the RWMC is considered a viable option for both RTC and NRF resin disposal through FY 2009. Since NRF resin is disposed of in the concrete vaults, disposal may continue past FY 2009 and be extended through at least 2015 when the vault will be at capacity (from the forecast) or until the final CERCLA Subsurface Disposal Area (SDA) remediation schedule removes the vaults as a disposal option. The RWMC, though viable in the short-term with continued use of the concrete vaults, is not considered a long-term viable option (through 2035) and will not be evaluated further.

B-2.2.2.2 Idaho CERCLA Disposal Facility (ICDF). The ICDF is an on-site disposal facility that accepts only CERCLA waste generated at the INL. The RH LLW resin is not a CERCLA generated waste; therefore, the ICDF is not considered a viable option and will not be evaluated further.

B-2.2.2.3 New On-site Disposal Facility. The concept for a new on-site disposal facility accepts all LLW. Once the new on-site disposal facility is operational, the RH LLW resin would be transported via an on-site transport plan using the same procedures as are currently in use. The new on-site LLW disposal facility, although in an early pre-conceptual planning stage, is considered a viable option and will be further evaluated.

\section{B-2.2.3 Disposal of RH LLW Resins at an Off-Site Disposal Facility}

For this alternative, the RH LLW resin would be disposed at an off-site facility. Eight off-site facilities are evaluated to satisfy this alternative.

B-2.2.3.1 DOE Disposal at Nevada Test Site in Nevada. This option would transport and dispose of the RH LLW resin at NTS. The logistics for moving the RTC RH LLW resin would be to continue using the certified NuPac 14-210L cask system for those resins meeting Type A or LSA/II transport requirements. NRF would need to reconfigure infrastructure to utilize the NuPac 14-210L cask system or another transport system such as a commercially available CNS21-300 or the Duratek 10-160B cask owned by Navy shipyards. The transportation support does exist to move the waste package from the INL to NTS. The resin waste stream has been reviewed against the NTS WAC and is expected to meet the disposal acceptance requirements. NTS disposal is viable and will be evaluated further in the analysis of options section.

B-2.2.3.2 DOE Disposal at Hanford in Washington. One major unresolved issue complicates disposal at Hanford. The DOE settled their lawsuit with the state of Washington on storing of untreated mixed transuranic waste by agreeing to halt shipments of LLW until a new environmental review is complete. This effectively prohibits the Hanford site from further disposal of out-of-state DOE-generated LLW. The EIS currently under development evaluates the impacts of receipt of $62,000 \mathrm{~m}^{3}$ of LLW from off-site. Though the waste meets the initial screening criteria for transporting to and disposal at DOE Hanford, the unresolved issues prevents Hanford from accepting any INL LLW. 
The logistics for moving the RTC RH LLW resin would be to continue using the certified NuPac 14-210L cask system for those resins meeting Type A or LSA/II transport requirements. NRF would need to reconfigure infrastructure to utilize the NuPac 14-210L cask system or another transport system such as a commercially available CNS21-300 or the Duratek 10-160B cask owned by Navy shipyards. The transportation support does exist to move the waste package from the INL to Hanford. The resin waste stream has been reviewed against the Hanford WAC and is expected to meet the disposal acceptance requirements.

Even though the resin is not expected to have technical barriers for transportation and waste disposal acceptance, this option is considered not to be viable until issues between the DOE and the state of Washington have been resolved and will not be evaluated further in the analysis of options sections.

B-2.2.3.3 DOE Disposal at Oak Ridge, Tennessee. The DOE disposal facility in Oak Ridge, Tennessee cannot receive off-site LLW. Therefore, this option is screened out from further evaluation.

B-2.2.3.4 DOE Disposal at SRS, South Carolina. The DOE disposal facility in South Carolina includes engineered concrete vaults and trenches. SRS receives only waste from on-site and activated metal components generated by the Navy. Because SRS cannot receive the RH LLW resins, this option is screened out from further evaluation.

B-2.2.3.5 Commercial Disposal at Barnwell, South Carolina. Barnwell, South Carolina is a commercial disposal facility considered as a disposal option. At the beginning of 2008, Barnwell is scheduled to enter into a compact with three Eastern states and at that time, the site will receive waste from only the compact states. RH LLW resin is not scheduled for off-site disposal until FY 2010, and so from a scheduling basis, the facility at Barnwell will be closed to INL waste. This option is screened out from further evaluation.

B-2.2.3.6 Commercial Disposal at U. S. Ecology in Hanford, Washington. This option would transport and dispose of the RH LLW resin at the U.S. Ecology facility in Hanford, Washington.

The logistics for moving the RTC RH LLW resin would be to continue using the certified NuPac 14-210L cask system for those resins meeting Type A or LSA/II transport requirements. NRF would need to reconfigure infrastructure to utilize the NuPac 14-210L cask system or another transport system such as a commercially available CNS21-300 or the Duratek 10-160B cask owned by Navy shipyards. The transportation support does exist to move the waste package from the INL to U.S. Ecology at Hanford.

U.S. Ecology accepts 10 Code of Federal Regulations (CFR) 61 Class A, B, and C commercial LLW from generators in the Northwest and Rocky Mountain Compact states. U.S. Ecology also can accept DOE generated LLW on a case-by-case basis provided that the waste does not adversely impact the disposal facilities license radiological limits or capacity for the commercial LLW generators. The resin waste stream has been reviewed against the U.S. Ecology license and is expected to meet the disposal acceptance requirements. U.S. Ecology is likely to limit the quantities of resins accepted or reject the waste streams. As U.S. Ecology disposal is tentatively viable, a rough order of magnitude cost comparison was done against just the disposal rates between U.S. Ecology and NTS in Table B-2-6 (no detailed cost analysis will be performed). Though a tentatively viable disposal option, cursory cost comparison indicates U.S. Ecology is not the most cost effective option and so will not be included in the analysis of options section. 
Table B-2-6. U.S. Ecology disposal costs (based on 2005 rate schedules) vs. Nevada Test Site disposal costs (based on 2006 rate schedules).

\begin{tabular}{|c|c|c|}
\hline \multicolumn{2}{|l|}{ U.S. Ecology } & \multirow[t]{2}{*}{$\$ 318,166$} \\
\hline Site Availability Charge (for $36 \mathrm{~m}^{3}$ ) & $\$ 32,464$ & \\
\hline Volume Charge (for $36 \mathrm{~m}^{3}$ ) & $\$ 101,693$ & \\
\hline Shipment Charge (for 6 shipments) & $\$ 63,840$ & \\
\hline Container Charge (for 6 containers) & $\$ 32,640$ & \\
\hline $\begin{array}{l}\text { Exposure Charge (for } 6 \text { containers assume greater than } 200 \\
\mathrm{mR} / \mathrm{h} \text { at contact) }\end{array}$ & $\$ 71,250$ & \\
\hline $\begin{array}{l}\text { Site Surveillance Fee, Surcharge and Perpetual Care and } \\
\text { Maintenance Fees (for } 36 \mathrm{~m}^{3} \text { ) }\end{array}$ & $\$ 3,298$ & \\
\hline Taxes & $\$ 12,981$ & \\
\hline NTS & & $\$ 17,796$ \\
\hline Disposal Costs (for $36 \mathrm{~m}^{3}$ at $\$ 14 / \mathrm{ft}^{3}$ ) & $\$ 17,796$ & \\
\hline
\end{tabular}

B-2.2.3.7 Commercial Disposal at Waste Control Specialists in Texas. WCS, in Texas, is a commercial disposal facility considered as a disposal option. WCS is in the process of applying for a NRC license to accept Class A, B, and C LLW and do not anticipate receiving a license until after 2007. As of June 5, the Texas Commission on Environmental Quality expressed extensive technical concerns about the company's license application, which may result in postponement of the license (Weapons Complex Monitor 2006). WCS does not have a published WAC; however, when the resin waste stream profile is compared against the WCS license application, no immediate acceptance issues are indicated. Texas law requires that ownership of the Federal waste portion of the WCS facility revert to the Federal government at the completion of waste receipt operations. DOE has not yet decided whether disposal under these conditions is acceptable, given that DOE might eventually have to take back the site.

From a schedule standpoint WCS may be a future option for resin disposal and as such will be reassessed. However, without a license, a cost schedule, or WAC, this disposal facility does not have enough information to evaluate against other available options and so is screened out from further evaluation.

B-2.2.3.8 Commercial Disposal at EnergySolutions in Utah. EnergySolutions (formerly Envirocare of Utah) is a commercial disposal facility considered as a disposal option. EnergySolutions is limited to accepting only NRC Class A waste. The ATR generated resins waste stream profile exceeds the EnergySolutions WAC for ${ }^{137} \mathrm{Cs},{ }^{90} \mathrm{Sr}$, and ${ }^{99} \mathrm{Tc}$ and is at the upper activity limit for ${ }^{14} \mathrm{C}$. The NRF generated resins waste stream profile exceeds the EnergySolutions WAC for ${ }^{90} \mathrm{Sr}$. The resins would fail the waste acceptance at EnergySolutions, so for this reason, this option is screened out from further evaluation.

\section{B-2.2.4 Analysis of Viable Disposal Options}

Both on-site and off-site disposal facilities were initially screened for viability resulting in one continued short-term option and two potential viable long-term disposal options.

B-2.2.4.1 Disposal of the RH LLW Resins at New On-site Disposal Facility. The concept for a new on-site disposal facility accepts all LLW. Part of the design considerations for a new RH LLW disposal facility would include the characteristics of the RH LLW resin and the long-term performance and monitoring requirements. 


\section{Protectiveness}

This option would be protective of public health, the community, and the environment during transportation to and disposal at a new on-site disposal facility. The waste would not leave the INL or use public highways resulting in the lowest transportation risk with the fewest miles of travel. Adhering to onsite transport plans and meeting the WAC and operational requirements at the new disposal facility will protect worker exposure. This option is protective of the environment, as the disposal facility will be designed to be compliant with all applicable nuclear safety operational and disposal regulations.

\section{Ability to Achieve Objectives}

As the new facility would specifically incorporate the resin as a waste type requiring disposal, no special assessments for long-term disposal would need to be completed. This option would achieve the objective for waste disposal.

\section{Technical Feasibility}

RH LLW resin disposal at a new on-site disposal facility is technically feasible. Construction of a new disposal facility would be based on an existing RH LLW disposal facility design and incorporated requirements applicable for the safe disposal of the waste.

\section{Availability of Equipment, Personnel, and Disposal Facilities}

Transportation methods and disposal the waste could be handled in a safe and routine manner using equipment, procedures, and personnel available but modified for the new on-site disposal facility. The availability of the disposal facility will be dependent on such details as the location studies, approval processes, construction schedule, and operational readiness reviews.

\section{Administrative Feasibility}

A new on-site disposal facility would incorporate the waste handling, storage, transportation, waste acceptance, disposal, and long-term monitoring for the RH LLW resin. This option is administratively feasible.

\section{B-2.2.4.2 Disposal of the RH LLW Resins at NTS}

\section{Protectiveness}

Disposal of the RH LLW resin at NTS would be protective of public health, the community, and the environment during transportation to and disposal at NTS. This option requires the waste to be transported in compliance with DOT requirements approximately 900 miles. This option results in the most miles traveled with transport over the public highway system with increases in the associated transportation risks. The route is restricted from going through Las Vegas, NV hence additional miles for the less direct route. This option would meet the NTS WAC and is protective of the environment as the disposal facility is compliant with DOE Order 435.1.

\section{Ability to Achieve Objectives}

This option would achieve the objectives for transportation and disposal of the waste package by following DOT regulations and by compliance with the NTS WAC. 


\section{Implementation}

Based on the criteria, disposal at NTS is implementable.

\section{Technical Feasibility}

This option is technically feasible. Transportation methods to and disposal of the waste at NTS are currently not routine but are achievable. The waste would be transported using DOT compliant packaging. No shipments will involve special DOT permitting.

\section{Availability of Equipment, Personnel, and Disposal Facilities}

The equipment and personnel necessary to complete the transportation and disposal is available with the exception that infrastructure changes will be needed to allow packaging for off-site shipment. The NTS will be available during the scheduled disposal period through 2027. From 2027 through 2035 the availability is uncertain.

\section{Administrative Feasibility}

Disposal of the waste at NTS is administratively feasible. The waste is expected to be compliant with the NTS WAC. Packaging and transportation will be compliant with the DOT requirements. The transportation and disposal schedule is complicated by off-site transportation over public highways.

\section{B-2.2.5 Comparative Analysis of the Disposal Options}

Ten disposal options were initially identified and evaluated to select one short-term option and two long-term viable options. The two viable long-term options were further evaluated for effectiveness, implementability, and costs for analysis of alternatives of the RH LLW resin waste, see Table B-2-7.

The option for RH LLW resin disposal at NTS supports Alternative 1 and the option for RH LLW resin disposal at a new on-site disposal facility supports Alternative 2. The options, when compared, as alternatives are similar in that each can achieve the disposal objectives for the RH LLW resin waste. Also, the waste is expected to meet the requirements of the WAC at each of the disposal facilities. The alternatives provide long-term environmental protectiveness and are compliant with DOT requirements or will follow a transport plan.

The differences are:

- Alternative 1 - Off-Site Disposal of RH LLW. This alternative incurs more worker and public risk than Alternative 2 due to more travel miles, travel over public highways. This option will require more administrative and scheduling than Alternative 2 and equal or more than Alternative 1b. U.S. Ecology has never received INL waste. This option is technically more complex than Alternative 2 due to the DOT requirements. This option costs more than Alternative 2.

- Alternative 2 - On-Site Disposal of RH LLW. This option has the least amount of public risk due to fewest travel miles, fewest number of moves and lifts, and no travel over public highways. This option has the least amount of worker risk because of the fewest travel miles. This option costs less than Alternative 1. 
Table B-2-7. Remote-handled low-level waste resin viable disposal alternatives

\begin{tabular}{|c|c|c|}
\hline & Alternative 1-Off-Site Disposal at NTS & $\begin{array}{c}\text { Alternative 2-On-Site Disposal at a } \\
\text { New Disposal Facility }\end{array}$ \\
\hline \multirow{6}{*}{ 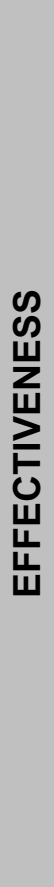 } & \multicolumn{2}{|l|}{ EFFECTIVENESS STATEMENT } \\
\hline & $\begin{array}{l}\text { Can achieve the objectives for transportation and disposal. } \\
\text { Alternative } 1 \text { results in: } \\
\text { - More miles traveled than Alternative } 2 \\
\text { - Includes travel on DOE roads and public highways } \\
\text { - More worker/public exposure than Alternative } 2 \\
\text { - More technical/administrative issues than Alternative } 2 \text {. }\end{array}$ & $\begin{array}{l}\text { Can achieve the objectives for transportation and disposal. } \\
\text { Alternative } 2 \text { results in: } \\
\text { - Least number of moves of waste } \\
\text { - Fewest travel miles } \\
\text { - No travel over public highways } \\
\text { - Lowest worker/public exposure } \\
\text { - Minimal technical/administrative issues. }\end{array}$ \\
\hline & \multicolumn{2}{|l|}{ Protectiveness } \\
\hline & $\begin{array}{l}\text { Less protective during transportation and disposal than } \\
\text { Alternative } 2 \text { because: } \\
\text { - Greater transport distance is required ( } ~ 900 \text { miles) through three } \\
\text { states } \\
\text { - Transport on DOE roadways and public highways } \\
\text { - Exposure to workers and public is potentially greater because } \\
\text { the waste is transported from the INL using road systems with } \\
\text { potential public exposures along the entire travel route } \\
\text { - Increased mileage increases the risk of potential accidents. } \\
\text { Environmental risk will be similar to Alternative } 2 \text { since each } \\
\text { facility is approved under DOE O } 435.1 \text {. }\end{array}$ & $\begin{array}{l}\text { More protective during transportation and disposal than Alternative } \\
1 \text { because: } \\
\text { - Least amount of miles traveled reduces transportation risks } \\
\text { - Due to limited travel miles, least potential environmental risk } \\
\text { - Least exposure potential to the public as the waste does not } \\
\text { leave the INL site } \\
\text { - Exposure to workers is less because the waste does not leave } \\
\text { the INL site, has limited travel distance and has least number of } \\
\text { moves and lifts. } \\
\text { Environmental risk will be similar to Alternative } 1 \text { since each facility } \\
\text { is approved under DOE O } 435.1 \text {. }\end{array}$ \\
\hline & \multicolumn{2}{|l|}{ Ability to Achieve Transportation and Disposal Objectives } \\
\hline & $\begin{array}{l}\text { All alternatives are capable of meeting transportation and disposal } \\
\text { objectives. }\end{array}$ & $\begin{array}{l}\text { All alternatives are capable of meeting the transportation and } \\
\text { disposal objectives. }\end{array}$ \\
\hline
\end{tabular}


Table B-2-7. (continued).

\begin{tabular}{|c|c|c|}
\hline & Alternative 1-Off-Site Disposal at NTS & $\begin{array}{c}\text { Alternative 2-On-Site Disposal at a } \\
\text { New Disposal Facility }\end{array}$ \\
\hline \multirow{10}{*}{ 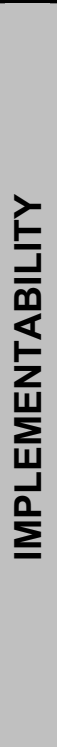 } & \multicolumn{2}{|l|}{ Technical Feasibility } \\
\hline & Technically feasible, but so is Alternative 2 . & Technically feasible, but so is Alternatives 1 . \\
\hline & \multicolumn{2}{|l|}{ Availability of Equipment } \\
\hline & All transport systems are available through subcontracts. & All lifting and transport systems are available on-site. \\
\hline & \multicolumn{2}{|l|}{ Personnel Services } \\
\hline & $\begin{array}{l}\text { Subcontract personnel and facility personnel with demonstrated } \\
\text { performance will conduct the transportation. Disposal facility } \\
\text { personnel will perform disposal. }\end{array}$ & $\begin{array}{l}\text { Facility personnel with demonstrated performance will conduct } \\
\text { transportation and disposal. }\end{array}$ \\
\hline & \multicolumn{2}{|l|}{ Disposal Facilities } \\
\hline & $\begin{array}{l}\text { More complicated to implement for transportation and disposal } \\
\text { action than Alternative } 2 \text { because: } \\
\text { - Off-site transportation is required complicating the planning, } \\
\text { approvals, and scheduling } \\
\text { - Transportation includes dedicated transport system (potential } \\
\text { commercially leases) } \\
\text { - Longer schedule required to complete disposal action } \\
\text { - Least operational experience with RH LLW disposals. }\end{array}$ & $\begin{array}{l}\text { Less complicated to implement for transportation and disposal than } \\
\text { Alternative } 1 \text { because: } \\
\text { - No off-site transportation required simplifying the planning and } \\
\text { scheduling } \\
\text { - Disposal completed in shortest time period } \\
\text { - No leased transport systems required } \\
\text { - Previous operational experience with RH LLW disposals. }\end{array}$ \\
\hline & \multicolumn{2}{|l|}{ Administrative Feasibility } \\
\hline & $\begin{array}{l}\text { Waste expected to meet WAC. Environmental Management } \\
\text { operations at NTS are currently scheduled through } 2027 \text {. }\end{array}$ & $\begin{array}{l}\text { Waste expected to meet new disposal facility WAC requiring no } \\
\text { special PA. New disposal facility life expected through } 2035 \text {. }\end{array}$ \\
\hline
\end{tabular}




\section{B-2.3 Activated Metals}

ATR produces activated metals during reactor core change-out operations approximately every 8 years. These components require $\sim 8$-yr decay time. Volume averages $\sim 3 \mathrm{~m}^{3} / \mathrm{yr}$ (as packaged estimate) and is forecasted through at least FY 2035. The activated metals are RH LLW in that package contact dose routinely exceed $200 \mathrm{mR} / \mathrm{hr}$ and have been documented at nearly $30,000 \mathrm{R} / \mathrm{hr}$. The activated metal would be classified under 10 CFR 61 typically as Class B and C with some exceeding Class C. Previous disposals of ATR activated metals have been at the RWMC using the Waste Calciner Filter (WCF) cask, see Tables B-2-8 and B-2-9. The WCF is used in conjunction with a transport plan and is not NRC licensed. Off-site transport of the ATR activated metals will require DOT Type B cask transport systems.

NRF produces activated metals during routine operations. Volume averages $\sim 35 \mathrm{~m}^{3} / \mathrm{yr}$ (as packaged estimate) and is forecasted through at least FY 2035. The NRF activated metals are RH LLW in that package contact dose routinely exceed $200 \mathrm{mR} / \mathrm{hr}$ and have been documented at nearly $30,000 \mathrm{R} / \mathrm{hr}$. Future projections are that on-contact dose rates will be $<15,000 \mathrm{R} / \mathrm{hr}$. Currently the waste is disposed in the RWMC concrete vaults in 55-ton scrap cask liners, see Table B-2-5. The 55-ton scrap cask is currently used to transport the waste with an on-site transport plan that provides requirements for safe waste shipments. Off-site transport of the NRF activated metals will require DOT Type B cask transport systems.

The Materials and Fuels Complex (MFC) will generate activated metals during waste segregation operations in the planned Remote Treatment Project (RTP). LLW stored at MFC consists primarily of irradiated reactor subassembly hardware that has been drained of sodium and fuel removed. The hardware is typically stainless steel. LLW is stored in a number of configurations including pre-1978 waste cans, and in the post 1978, HFEF 5-Cask waste cans. Some of the LLW is co-mingled with other waste types and will have to be retrieved and sorted in RTP. The operations are expected to produce $\sim 6 \mathrm{~m}^{3} / \mathrm{y}$ (as packaged estimate) of activated metal. The MFC activated metals will be RH LLW in that package contact dose is expected to routinely exceed $200 \mathrm{mR} / \mathrm{hr}$ and like the NRF and ATR activated metals could reach 30,000 R/hr. The MFC activated metal would be classified under 10 CFR 61 typically as Class B and $\mathrm{C}$ with about $50 \%$ exceeding Class $\mathrm{C}$. No specific activity information is included. The RTP is expected to operate FY 2012 through 2035. Off-site transport of the MFC activated metals will require DOT Type B cask transport systems. 
Table B-2-8. Remote-handled low-level waste Advanced Test Reactor core structural parts.

\begin{tabular}{|c|c|c|c|c|}
\hline Nuclide & $\mathrm{Ci} / \mathrm{m}^{3}$ & $\mathrm{Ci} / \mathrm{g}$ & $\begin{array}{l}\mathrm{Ci} / \mathrm{m}^{3} \\
(\max )\end{array}$ & $\begin{array}{c}\mathrm{Ci} / \mathrm{g} \\
(\max )\end{array}$ \\
\hline C-14 & $4.8 \mathrm{E}-03$ & $9.2 \mathrm{E}-09$ & $1.8 \mathrm{E}-02$ & $3.4 \mathrm{E}-08$ \\
\hline $\mathrm{Cl}-36$ & $3.9 \mathrm{E}-06$ & $1.7 \mathrm{E}-11$ & $3.9 \mathrm{E}-06$ & $1.7 \mathrm{E}-11$ \\
\hline Co-58 & $6.5 \mathrm{E}+00$ & $1.2 \mathrm{E}-05$ & $6.5 \mathrm{E}+00$ & $1.2 \mathrm{E}-05$ \\
\hline Co-60 & $1.7 \mathrm{E}+02$ & 5.7E-04 & $8.9 \mathrm{E}+02$ & $3.9 \mathrm{E}-03$ \\
\hline Cr-51 & $2.8 \mathrm{E}+01$ & $1.0 \mathrm{E}-04$ & $7.2 \mathrm{E}+01$ & $3.0 \mathrm{E}-04$ \\
\hline $\mathrm{Fe}-55$ & $5.1 \mathrm{E}+02$ & $1.9 \mathrm{E}-03$ & $3.0 \mathrm{E}+03$ & $1.0 \mathrm{E}-02$ \\
\hline $\mathrm{Fe}-59$ & 7.7E-01 & $2.9 \mathrm{E}-06$ & $1.0 \mathrm{E}+00$ & 4.3E-06 \\
\hline $\mathrm{H}-3$ & $2.3 \mathrm{E}+04$ & $3.3 \mathrm{E}-02$ & $1.3 \mathrm{E}+05$ & 4.7E-01 \\
\hline Ir-192 & 2.7E-06 & $1.2 \mathrm{E}-11$ & $2.7 \mathrm{E}-06$ & $1.2 \mathrm{E}-11$ \\
\hline Mn-54 & $2.6 \mathrm{E}+01$ & $9.0 \mathrm{E}-05$ & $1.1 \mathrm{E}+02$ & $3.2 \mathrm{E}-04$ \\
\hline Мo-93 & $4.5 \mathrm{E}-03$ & $2.0 \mathrm{E}-08$ & $4.5 \mathrm{E}-03$ & $2.0 \mathrm{E}-08$ \\
\hline $\mathrm{Nb}-93 \mathrm{~m}$ & $1.5 \mathrm{E}-06$ & $7.2 \mathrm{E}-12$ & $2.0 \mathrm{E}-06$ & $9.6 \mathrm{E}-12$ \\
\hline $\mathrm{Nb}-94$ & $5.2 \mathrm{E}-02$ & $2.3 \mathrm{E}-07$ & $1.6 \mathrm{E}-01$ & $6.9 \mathrm{E}-07$ \\
\hline $\mathrm{Nb}-95$ & $1.7 \mathrm{E}+02$ & 4.9E-04 & $1.7 \mathrm{E}+02$ & 4.9E-04 \\
\hline $\mathrm{Ni}-59$ & $1.3 \mathrm{E}-01$ & $6.5 \mathrm{E}-07$ & $3.8 \mathrm{E}-01$ & 2.2E-06 \\
\hline $\mathrm{Ni}-63$ & $1.3 \mathrm{E}+02$ & $2.4 \mathrm{E}-04$ & $1.3 \mathrm{E}+03$ & $4.8 \mathrm{E}-03$ \\
\hline Os-194 & $2.0 \mathrm{E}-06$ & 8.9E-12 & $2.0 \mathrm{E}-06$ & $8.9 \mathrm{E}-12$ \\
\hline Pm-147 & $3.1 \mathrm{E}+00$ & $1.3 \mathrm{E}-05$ & $3.1 \mathrm{E}+00$ & $1.3 \mathrm{E}-05$ \\
\hline Sb-125 & $8.3 \mathrm{E}+00$ & $2.5 \mathrm{E}-05$ & $2.7 \mathrm{E}+01$ & $8.2 \mathrm{E}-05$ \\
\hline Sc-46 & $3.7 \mathrm{E}+01$ & $1.4 \mathrm{E}-04$ & $6.5 \mathrm{E}+01$ & $2.7 \mathrm{E}-04$ \\
\hline Sn-113 & $1.4 \mathrm{E}+01$ & $4.3 \mathrm{E}-05$ & $2.4 \mathrm{E}+01$ & $7.0 \mathrm{E}-05$ \\
\hline Sn-117m & $7.8 \mathrm{E}+01$ & $2.4 \mathrm{E}-04$ & $1.5 \mathrm{E}+02$ & 4.4E-04 \\
\hline Sn-119m & $1.8 \mathrm{E}+01$ & $5.1 \mathrm{E}-05$ & $6.7 \mathrm{E}+01$ & $1.9 \mathrm{E}-04$ \\
\hline $\mathrm{Sn}-121 \mathrm{~m}$ & $1.4 \mathrm{E}-04$ & $5.9 \mathrm{E}-10$ & $1.8 \mathrm{E}-04$ & $7.9 \mathrm{E}-10$ \\
\hline Sr-90 & $1.7 \mathrm{E}-07$ & 7.2E-13 & 4.9E-07 & $2.2 \mathrm{E}-12$ \\
\hline Tc-99 & $1.8 \mathrm{E}-05$ & $6.1 \mathrm{E}-11$ & $3.7 \mathrm{E}-05$ & $1.6 \mathrm{E}-10$ \\
\hline $\mathrm{Te}-125 \mathrm{~m}$ & $1.8 \mathrm{E}+01$ & $5.3 \mathrm{E}-05$ & $5.2 \mathrm{E}+01$ & $1.5 \mathrm{E}-04$ \\
\hline $\mathrm{Zn}-65$ & $2.6 \mathrm{E}+02$ & $1.1 \mathrm{E}-03$ & $1.0 \mathrm{E}+03$ & 4.4E-03 \\
\hline Zr-93 & $1.1 \mathrm{E}-06$ & $5.0 \mathrm{E}-12$ & $2.2 \mathrm{E}-06$ & $9.5 \mathrm{E}-12$ \\
\hline Zr-95 & $8.1 \mathrm{E}+01$ & $2.4 \mathrm{E}-04$ & $8.1 \mathrm{E}+01$ & $2.4 \mathrm{E}-04$ \\
\hline
\end{tabular}


Table B-2-9. Remote-handled low-level waste Advanced Test Reactor core subassembly parts.

\begin{tabular}{|c|c|c|c|c|}
\hline Nuclide & $\mathrm{Ci} / \mathrm{m}^{3}$ & $\mathrm{Ci} / \mathrm{g}$ & $\begin{array}{l}\mathrm{Ci} / \mathrm{m}^{3} \\
(\max )\end{array}$ & $\begin{array}{c}\mathrm{Ci} / \mathrm{g} \\
(\max )\end{array}$ \\
\hline C-14 & $4.8 \mathrm{E}-03$ & $9.2 \mathrm{E}-09$ & $1.8 \mathrm{E}-02$ & $3.4 \mathrm{E}-08$ \\
\hline $\mathrm{Cl}-36$ & $3.9 \mathrm{E}-06$ & $1.7 \mathrm{E}-11$ & $3.9 \mathrm{E}-06$ & $1.7 \mathrm{E}-11$ \\
\hline Co-58 & $6.5 \mathrm{E}+00$ & $1.2 \mathrm{E}-05$ & $6.5 \mathrm{E}+00$ & $1.2 \mathrm{E}-05$ \\
\hline Co-60 & $1.5 \mathrm{E}+02$ & $5.8 \mathrm{E}-04$ & $8.9 \mathrm{E}+02$ & $3.9 \mathrm{E}-03$ \\
\hline Cr-51 & $2.8 \mathrm{E}+01$ & $1.0 \mathrm{E}-04$ & $7.2 \mathrm{E}+01$ & $3.0 \mathrm{E}-04$ \\
\hline $\mathrm{Fe}-55$ & $5.1 \mathrm{E}+02$ & $1.9 \mathrm{E}-03$ & $3.0 \mathrm{E}+03$ & $1.0 \mathrm{E}-02$ \\
\hline $\mathrm{Fe}-59$ & 7.7E-01 & $2.9 \mathrm{E}-06$ & $1.0 \mathrm{E}+00$ & 4.3E-06 \\
\hline $\mathrm{H}-3$ & $1.6 \mathrm{E}-03$ & $6.3 \mathrm{E}-09$ & $5.4 \mathrm{E}-03$ & $2.4 \mathrm{E}-08$ \\
\hline Ir-192 & $2.7 \mathrm{E}-06$ & $1.2 \mathrm{E}-11$ & $2.7 \mathrm{E}-06$ & $1.2 \mathrm{E}-11$ \\
\hline Mn-54 & $2.6 \mathrm{E}+01$ & $9.0 \mathrm{E}-05$ & $1.1 \mathrm{E}+02$ & $3.2 \mathrm{E}-04$ \\
\hline Mo-93 & $4.5 \mathrm{E}-03$ & $2.0 \mathrm{E}-08$ & $4.5 \mathrm{E}-03$ & $2.0 \mathrm{E}-08$ \\
\hline $\mathrm{Nb}-93 \mathrm{~m}$ & $1.5 \mathrm{E}-06$ & 7.2E-12 & $2.0 \mathrm{E}-06$ & $9.6 \mathrm{E}-12$ \\
\hline $\mathrm{Nb}-94$ & $5.2 \mathrm{E}-02$ & $2.3 \mathrm{E}-07$ & $1.6 \mathrm{E}-01$ & $6.9 \mathrm{E}-07$ \\
\hline $\mathrm{Nb}-95$ & $1.7 \mathrm{E}+02$ & 4.9E-04 & $1.7 \mathrm{E}+02$ & 4.9E-04 \\
\hline $\mathrm{Ni}-59$ & $1.3 \mathrm{E}-01$ & $6.5 \mathrm{E}-07$ & $3.8 \mathrm{E}-01$ & 2.2E-06 \\
\hline Ni-63 & $2.0 \mathrm{E}+01$ & $8.0 \mathrm{E}-05$ & $1.1 \mathrm{E}+02$ & $4.6 \mathrm{E}-04$ \\
\hline Os-194 & $2.0 \mathrm{E}-06$ & $8.9 \mathrm{E}-12$ & $2.0 \mathrm{E}-06$ & 8.9E-12 \\
\hline Pm-147 & $3.1 \mathrm{E}+00$ & $1.3 \mathrm{E}-05$ & $3.1 \mathrm{E}+00$ & $1.3 \mathrm{E}-05$ \\
\hline Sb-125 & $8.3 \mathrm{E}+00$ & $2.5 \mathrm{E}-05$ & $2.7 \mathrm{E}+01$ & $8.2 \mathrm{E}-05$ \\
\hline Sc-46 & $3.7 \mathrm{E}+01$ & $1.4 \mathrm{E}-04$ & $6.5 \mathrm{E}+01$ & 2.7E-04 \\
\hline Sn-113 & $1.4 \mathrm{E}+01$ & 4.3E-05 & $2.4 \mathrm{E}+01$ & 7.0E-05 \\
\hline Sn-117m & $7.8 \mathrm{E}+01$ & $2.4 \mathrm{E}-04$ & $1.5 \mathrm{E}+02$ & 4.4E-04 \\
\hline Sn-119m & $1.8 \mathrm{E}+01$ & $5.1 \mathrm{E}-05$ & $6.7 \mathrm{E}+01$ & $1.9 \mathrm{E}-04$ \\
\hline $\mathrm{Sn}-121 \mathrm{~m}$ & $1.4 \mathrm{E}-04$ & $5.9 \mathrm{E}-10$ & $1.8 \mathrm{E}-04$ & 7.9E-10 \\
\hline Sr-90 & $1.7 \mathrm{E}-07$ & 7.2E-13 & 4.9E-07 & $2.2 \mathrm{E}-12$ \\
\hline Tc-99 & $1.8 \mathrm{E}-05$ & $6.1 \mathrm{E}-11$ & $3.7 \mathrm{E}-05$ & $1.6 \mathrm{E}-10$ \\
\hline Te- $125 \mathrm{~m}$ & $1.8 \mathrm{E}+01$ & 5.3E-05 & $5.2 \mathrm{E}+01$ & $1.5 \mathrm{E}-04$ \\
\hline $\mathrm{Zn}-65$ & $2.6 \mathrm{E}+02$ & $1.1 \mathrm{E}-03$ & $1.0 \mathrm{E}+03$ & 4.4E-03 \\
\hline Zr-93 & $1.1 \mathrm{E}-06$ & $5.0 \mathrm{E}-12$ & $2.2 \mathrm{E}-06$ & $9.5 \mathrm{E}-12$ \\
\hline $\mathrm{Zr}-95$ & $8.1 \mathrm{E}+01$ & $2.4 \mathrm{E}-04$ & $8.1 \mathrm{E}+01$ & $2.4 \mathrm{E}-04$ \\
\hline
\end{tabular}




\section{B-2.3.1 Activated Metal Disposal Assumptions and Initial Screening}

Assumptions were formulated to permit disposal options analysis. The assumptions are as follows for the ATR activated metal:

- The waste can be stored in the ATR canal until the next core internals change-out $(\sim 2014)$.

- ATR activated metal forecast is $\sim 3 \mathrm{~m}^{3}$ per year.

- $\quad$ The waste packages will be disposed FY 2014-2035.

- Radiological characterization information is based on best available information.

- The June 2006 disposal facility WACs are assumed to remain unchanged and provide the criteria governing disposals.

- The waste package will comply with DOT (off-site transport) and transport plan (on-site transport).

Assumptions were formulated to permit disposal options analysis. The assumptions are as follows for the MFC activated metal:

- The MFC activated metal will be generated as the waste stored at the RWSF is processed through the RTP scheduled for operations in FY 2012.

- MFC waste as generated from the RTP can be stored in RWSF vaults until disposal is available.

- $\quad$ MFC activated metal forecast is $\sim 6 \mathrm{~m}^{3}$ per year.

- $\quad$ The waste packages will be disposed FY 2014-2035.

- Radiological characterization information is based on best available information.

- The June 2006 disposal facility WACs are assumed to remain unchanged and provide the criteria governing disposals.

- $\quad$ The waste package will comply with DOT (off-site transport) and transport plan (on-site transport).

Assumptions were formulated to permit disposal options analysis. The assumptions are as follows for the NRF activated metal:

- The waste can continue to be disposed of in the RWMC LLW concrete vaults until the vaults are volumetrically filled or the RWMC CERCLA final remedial action necessitates closure of the SDA.

- $\mathrm{NRF}$ activated metal forecast is $\sim 35 \mathrm{~m}^{3}$ per year.

- $\quad$ The waste packages will be disposed FY 2014-2035.

- Radiological characterization information is based on best available information.

- The June 2006 disposal facility WACs are assumed to remain unchanged and provide the criteria governing disposals.

- $\quad$ The waste package will comply with DOT (off-site transport) and transport plan (on-site transport). 


\section{B-2.3.2 Disposal of RH LLW activated metal at an On-Site Disposal Facility}

For this alternative, the RH LLW activated metal would be disposed at an on-site facility. Three on-site disposal options are evaluated to satisfy this alternative.

B-2.3.2.1 Radioactive Waste Management Complex (RWMC). Activated metal waste from NRF is currently disposed at the RWMC. ATR has disposed at the RWMC although not recently. Activated metal waste from ATR has used the ATR WCF cask and liner system and could dispose in the concrete vaults. Activated metal waste from MFC will undergo separation and packaging at the RTP starting in 2012. Disposal at the RWMC is anticipated through at least FY 2009 although the vaults have capacity that may extend past 2015, see Figure B-2-1.

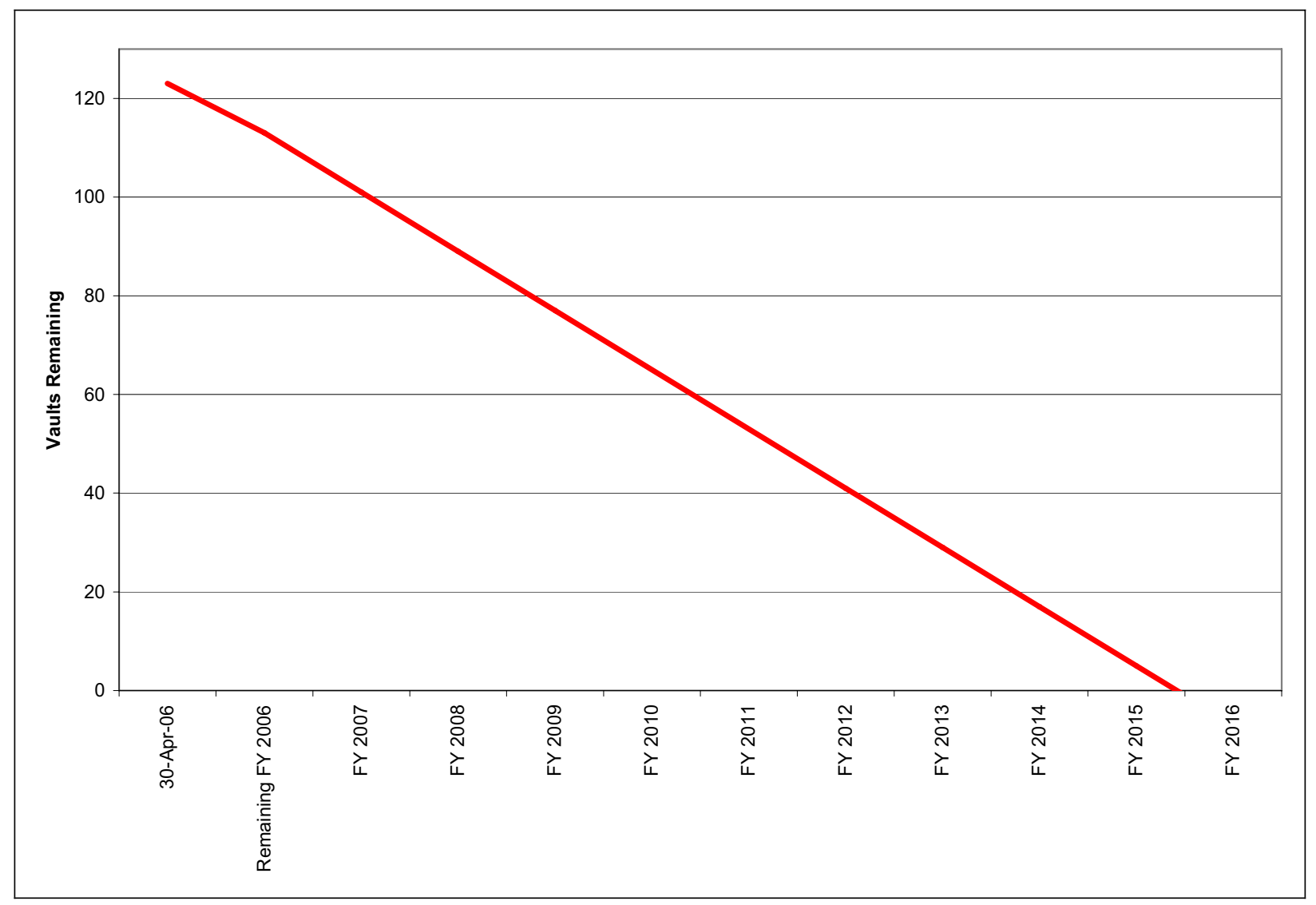

Figure B-2-1. Remote-handled low-level waste vault disposal forecast.

For this analysis, the RWMC is considered a viable option for both INL activated metal disposal while vault volume is available or until the final CERCLA SDA remediation schedule removes the vaults as a disposal option. The RWMC, though viable in the short-term with continued use of the concrete vaults, is not considered a long-term viable option (through 2035) and will not be evaluated further.

B-2.3.2.2 Idaho CERCLA Disposal Facility (ICDF). The ICDF is an on-site disposal facility that accepts only CERCLA waste generated at the INL. The RH LLW activated metals from NRF, ATR, and MFC are not a CERCLA generated waste; therefore, the ICDF is not considered a viable option and will not be evaluated further. 
B-2.3.2.3 New On-site Disposal Facility. The concept for a new on-site disposal facility accepts all LLW. Once the new on-site disposal facility is operational, the RH LLW activated metal would be transported via an on-site transport plan using the same procedures as are currently in use. The new on-site LLW disposal facility, although in an early pre-conceptual planning stage, is considered a viable option and will be further evaluated.

\section{B-2.3.3 Disposal of RH LLW Activated Metal at an Off-Site Disposal Facility}

For this alternative, the RH LLW activated metals would be disposed at an off-site facility. Eight off-site facilities are evaluated to satisfy this alternative.

B-2.3.3.1 DOE Disposal at Nevada Test Site in Nevada. This option would transport and dispose of the RH LLW activated metal at NTS.

The logistics for moving the INL RH LLW activated metal would be to procure truck-loaded casks with shielded transfer systems. NRF and ATR would need to reconfigure infrastructure to utilize a truckloaded system. MFC would need to design the infrastructure requirements into the design of the RTP. NTS would also need interface equipment such as a transfer bell(s) for disposal operations.

The activated metal waste streams have been reviewed against the NTS WAC and are expected to meet the disposal acceptance requirements although some of the waste shipments may require a special PA. NTS disposal is viable and will be evaluated further in the analysis of options section.

B-2.3.3.2 DOE Disposal at Hanford in Washington. One major unresolved issue complicates disposal at Hanford. The DOE settled their lawsuit with the state of Washington on storing of untreated mixed transuranic waste by agreeing to halt shipments of LLW until a new environmental review is complete. This effectively prohibits the Hanford site from further disposal of out-of-state DOE-generated LLW. The review underway is evaluating impacts of shipping $62,000 \mathrm{~m}^{3}$ of waste to Hanford from offsite. Though the waste meets the initial screening criteria for disposal at DOE Hanford, the unresolved issues prevents Hanford from accepting any INL LLW.

The logistics for moving the INL RH LLW activated metal would be to use both truck-loaded and rail-loaded cask systems. NRF would need minimal reconfiguration of infrastructure for a rail-mounted cask. ATR would need to reconfigure infrastructure and/or add interface equipment such as a transfer bell to utilize the truck-loaded cask. MFC would need to design the infrastructure requirements into the design of the RTP. Hanford would also need interface equipment such as a transfer bell for disposal operations.

The RH LLW activated metal has been reviewed against the Hanford WAC and is expected to meet the disposal acceptance requirements. The RH LLW activated metal is not expected to have technical barriers for transportation and waste disposal acceptance. For the purposes of establishing a comparison basis, Hanford will be included in the analysis of options sections based on the assumption that the issue between DOE and the state will have been resolved by the time a cask system is available for transport.

B-2.3.3.3 DOE Disposal at Oak Ridge, Tennessee. The DOE disposal facility in Oak Ridge, Tennessee cannot receive off-site LLW. Therefore, this option is screened out from further evaluation.

B-2.3.3.4 DOE Disposal at Savannah River Site, South Carolina. The DOE disposal facility in South Carolina includes engineered vaults and trenches. SRS only receives waste from on-site and activated metal components generated by the Navy. Because SRS can receive only a portion of the RH LLW activated metals generated at INL, this option is screened out from further evaluation. However, 
this option could be a back-up for disposal of NRF's activated metals should other disposal options become available.

B-2.3.3.5 Commercial Disposal at Barnwell, South Carolina. Barnwell, South Carolina is a commercial disposal facility considered as a disposal option. At the beginning of 2008, Barnwell is scheduled to enter into a compact with three Eastern states and at that time, the site will receive waste from only the compact states. RH LLW activated metal is not scheduled for off-site disposal until FY 2010, and so from a scheduling basis, the facility at Barnwell will be closed to INL waste. This option is screened out from further evaluation.

B-2.3.3.6 Commercial Disposal at U.S. Ecology at Hanford, Washington. This option would transport and dispose of the RH LLW activated metals at the U.S. Ecology facility at Hanford, Washington. U.S. Ecology accepts 10 CFR 61 Class A, B, and C commercial LLW from generators in the Northwest and Rocky Mountain Compact states. U.S. Ecology also can accept DOE generated LLW provided that the waste does not adversely impact the disposal facilities license radiological limits or capacity for the commercial LLW generators. The RH LLW activated metal has been reviewed against the U.S. Ecology license. The waste meeting Class B and C is expected to meet the disposal acceptance requirements; however, there exists a portion of the waste that exceeds 10 CFR 61 Class $C$ that could not be accepted.

The logistics for moving the INL RH LLW activated metal would be similar to transport and disposal at Hanford because both truck-loaded and rail-loaded cask systems would be used.

The RH LLW activated metal has been reviewed against the U.S. Ecology license and only a portion of the waste is expected to meet the disposal acceptance requirements. U.S. Ecology would likely reject the waste based on the quantities of radionuclides that will impact the license radiological limits. Although U.S. Ecology disposal is qualifiedly viable, not all the waste will meet the WAC, the waste may be rejected entirely, and another option will need to be selected at the very minimum to accommodate rejected waste. U.S. Ecology will not be evaluated further in the analysis of options section.

B-2.3.3.7 Commercial Disposal at Waste Control Specialists in Texas. WCS, in Texas, is a commercial disposal facility considered as a disposal option. WCS is in the process of applying for a NRC license to accept Class A, B, and C LLW and do not anticipate receiving a license until after 2007. As of June 5, the Texas Commission on Environmental Quality expressed extensive technical concerns about the company's license application, which may result in postponement of the license (Weapons Complex Monitor 2006). WCS does not have published WAC; however, when the activated metal is compared against the WCS license application, no immediate acceptance issues are indicated except for the portion of the waste that exceeds 10 CFR 61 Class C. The activated metal characteristically has significant quantities of ${ }^{14} \mathrm{C},{ }^{63} \mathrm{Ni},{ }^{59} \mathrm{Ni},{ }^{60} \mathrm{Co}$, and ${ }^{3} \mathrm{H}$, and over 25 years disposal schedule would impact the disposal facility license radiological limits.

From a schedule standpoint, WCS may be a future option for activated metal disposal and as such will be reassessed after WCS attains licensing. However, without a license, a cost schedule, or WAC, this disposal facility does not have enough information to evaluate against other available options and so is screened out from further evaluation. Furthermore, Texas law requires that ownership of the Federal waste portion of the WCS facility revert to the Federal government at the completion of waste receipt operations. DOE has not yet decided whether disposal under these conditions is acceptable, given that DOE might eventually have to take back the site.

B-2.3.3.8 Commercial Disposal at EnergySolutions in Utah. EnergySolutions (formerly Envirocare of Utah) is a commercial disposal facility considered as a disposal option. EnergySolutions is 
limited to accepting only NRC Class A waste. The RH LLW activated metals will generally be NRC Class B or C and in some cases GTCC. The RH LLW activated metals would fail the waste acceptance at EnergySolutions, so for this reason, this option is screened out from further evaluation.

\section{B-2.3.4 Analysis of Viable Disposal Options}

Both on-site and off-site disposal facilities were initially screened for viability. The screening resulted in one continued short-term on-site option at the RWMC and one long-term on-site option - a new on-site LLW disposal facility. For the purpose of this analysis only the new on-site LLW disposal facility will be included in the comparison. Also, the screening resulted in two potential viable long-term off-site disposal options.

B-2.3.4.1 Disposal of the RH LLW Activated metals at New On-site Disposal Facility. The concept for a new on-site disposal facility accepts all LLW. Part of the design considerations for a new RH LLW disposal facility would include the characteristics of the RH LLW activated metal and the longterm performance and monitoring requirements.

\section{Protectiveness}

This option would be protective of public health, the community, and the environment during transportation to and disposal at a new on-site disposal facility. The waste would not leave the INL or use public highways resulting in the lowest transportation risk with the fewest miles of travel. Adhering to on-site transport plans and meeting the WAC and operational requirements at the new disposal facility will protect worker exposure. This option is protective of the environment, as the disposal facility will be designed to be compliant with all applicable nuclear safety operational and disposal regulations.

\section{Ability to Achieve Objectives}

As the new facility would specifically incorporate the activated metal as a waste type requiring disposal, no special assessments for long-term disposal would need to be completed. This option would achieve the objective for waste disposal.

\section{Technical Feasibility}

RH LLW activated metal disposal at a new on-site disposal facility is technically feasible. Construction of a new disposal facility would be based on an existing RH LLW disposal facility design and incorporated requirements applicable for the safe disposal of the waste.

\section{Availability of Equipment, Personnel, and Disposal Facilities}

Transportation methods and disposal of the waste could be handled in a safe and routine manner using equipment, procedures, and personnel available but modified for the new on-site disposal facility. The availability of the disposal facility will be dependent on such details as the location studies, approval processes, construction schedule, and operational readiness reviews.

\section{Administrative Feasibility}

A new on-site disposal facility would incorporate the waste handling, storage, transportation, waste acceptance, disposal, and long-term monitoring for the RH LLW activated metal. This option is administratively feasible. 


\section{B-2.3.4.2 Disposal of the RH LLW Activated Metal at Hanford}

\section{Protectiveness}

Disposal of the RH LLW activated metal at Hanford would be protective of public health, the community, and the environment during transportation to and disposal at Hanford. This option requires the waste to be transported in compliance with DOT requirements. This option results in approximately 700 miles of travel with transport over railroad and DOE site roads. This option would meet the Hanford WAC. The disposal facility is compliant with DOE Order 435.1 but the EIS, yet to be released, would make a determination on protectiveness of the environment.

\section{Ability to Achieve Objectives}

This option would achieve the objectives for transportation and disposal of the waste package by following DOT regulations and by compliance with the Hanford WAC.

\section{Implementation}

Based on the criteria, disposal at Hanford is implementable.

\section{Technical Feasibility}

This option is technically feasible. Transportation methods to and disposal of the waste at Hanford are currently routine and achievable. The waste would be transported using DOT compliant packaging, packaging that would need to be designed to meet the current Type B packaging and testing requirements. No shipment will involve special DOT permitting.

\section{Availability of Equipment, Personnel, and Disposal Facilities}

The personnel necessary to complete the transportation and disposal are available. The equipment will need to be designed, developed, tested, and implemented. The rail-loaded cask systems are not expected to be available until 2014. The Hanford site will be available during the scheduled disposal period through 2035.

\section{Administrative Feasibility}

One major unresolved administrative issue complicates disposal at Hanford. The DOE settled their lawsuit with the state of Washington on storing of untreated mixed transuranic waste by agreeing to halt shipments of LLW until a new environmental review is complete. This effectively prohibits the Hanford site from further disposal of out-of-state DOE-generated LLW. The EIS will evaluate the impacts of transportation of $62,000 \mathrm{~m}^{3}$ of LLW from off-site. Disposal of the waste at Hanford is currently not administratively feasible.

\section{B-2.3.4.3 Disposal of the RH LLW Activated Metal at NTS}

\section{Protectiveness}

Disposal of the RH LLW activated metal at NTS would be protective of public health, the community, and the environment during transportation to and disposal at NTS. This option requires the waste to be transported in compliance with DOT requirements. This option results in approximately 900 miles traveled with transport over the public highway system with increases in the associated 
transportation risks. This option would meet the NTS WAC and is protective of the environment as the disposal facility is compliant with DOE Order 435.1.

\section{Ability to Achieve Objectives}

This option would achieve the objectives for transportation and disposal of the waste package by following DOT regulations and by compliance with the NTS WAC.

\section{Implementation}

Based on the criteria, disposal at NTS is implementable.

\section{Technical Feasibility}

This option is technically feasible. Transportation methods to and disposal of the waste at NTS are currently not routine but are achievable. The waste would be transported using DOT compliant packaging, packaging that would need to be designed to meet the current Type B packaging and testing requirements. No shipments will involve special DOT permitting.

\section{Availability of Equipment, Personnel, and Disposal Facilities}

The personnel necessary to complete the transportation and disposal are available. The equipment will need to be designed, developed, tested, and implemented. The cask systems are expected to be available in 2012. The NTS will be available during the scheduled disposal period through 2027. From 2027 through 2035 the availability is uncertain.

\section{Administrative Feasibility}

Disposal of the waste at NTS is administratively feasible. The waste is expected to be compliant with the NTS WAC or have a special performance review with acceptance. Packaging and transportation will compliant with the DOT requirements. The transportation and disposal schedule is complicated by off-site transportation over public highways.

\section{B-2.3.5 Comparative Analysis of the Disposal Options}

Ten disposal options were initially identified and evaluated to select one on-site option and two off-site options. The option for RH LLW activated metal disposal at NTS supports Alternative 1a, the option for RH LLW activated metal disposal at Hanford supports Alternative $1 \mathrm{~b}$ and the option for RH LLW activated metal disposal at a new on-site disposal facility supports Alternative 2 . The options, when compared as alternatives side by side are in Table B-2-10. 
Table B-2-10. Remote-handled low-level waste activated metal disposal alternatives.

\begin{tabular}{|c|c|c|c|}
\hline & $\begin{array}{c}\text { Alternative 1a-Off-Site } \\
\text { Disposal at NTS }\end{array}$ & $\begin{array}{c}\text { Alternative } 1 \mathrm{~b} \text {-Off-Site } \\
\text { Disposal at Hanford }\end{array}$ & $\begin{array}{c}\text { Alternative 2- On-Site } \\
\text { Disposal at a } \\
\text { New Disposal Facility }\end{array}$ \\
\hline \multirow{6}{*}{ 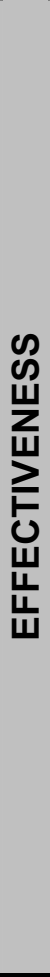 } & \multicolumn{3}{|l|}{ EFFECTIVENESS STATEMENT } \\
\hline & $\begin{array}{l}\text { Can achieve the objectives for transportation and } \\
\text { disposal. } \\
\text { Alternative } 1 \text { a results in: } \\
\text { - Most miles traveled ( } 900 \text { miles) } \\
\text { - Most number of shipments } \\
\text { - Includes travel on DOE roads and public highways } \\
\text { - More worker/public exposure than Alternative } 2 \text { or } \\
\text { Alternative } 1 \mathrm{~b} \\
\text { - More technical/administrative issues than } \\
\text { Alternative } 2 \text { or Alternative } 1 \mathrm{~b} \text {. }\end{array}$ & $\begin{array}{l}\text { Can achieve the objectives for transportation and disposal once } \\
\text { issues between the State of Washington and DOE are resolved } \\
\text { including conclusion of new Hanford EIS. } \\
\text { Alternative } 1 \mathrm{~b} \text { results in: } \\
\text { - More miles traveled ( } 700 \text { miles) than Alternative } 2 \text { but, less } \\
\text { than Alternative } 1 \mathrm{a} \\
\text { - Includes travel on DOE roads, public roads, and railroads } \\
\text { - More worker/public exposure than Alternative } 2 \text {, but less than } \\
\text { Alternative } 1 \mathrm{a} \\
\text { - More technical/administrative issues than Alternative } 2 \text { or } \\
\text { Alternative } 1 \mathrm{a}\end{array}$ & $\begin{array}{l}\text { Can achieve the objectives for transportation } \\
\text { and disposal. } \\
\text { Alternative } 2 \text { results in: } \\
\text { - Least number of moves of waste } \\
\text { - Fewest travel miles } \\
\text { - No travel over public highways } \\
\text { - Lowest worker/public exposure } \\
\text { - Minimal technical/administrative issues. }\end{array}$ \\
\hline & \multicolumn{3}{|l|}{ Protectiveness } \\
\hline & $\begin{array}{l}\text { Less protective during transportation than Alternative } \\
2 \text { and Alternative } 1 \mathrm{~b} \text { because: } \\
\text { - More moves and lifts are required } \\
\text { - Greater transport distance is required } \\
\text { - Transport on DOE roadways and public highways } \\
\text { - Exposure to workers and public is potentially } \\
\text { greater because the waste is transported from the } \\
\text { INL using road systems with potential public } \\
\text { exposures along the entire travel route } \\
\text { - Increased mileage increases the risk of potential } \\
\text { accidents. } \\
\text { Environmental risk at each disposal site will be similar } \\
\text { since each facility is approved under DOE O } 435.1 \text {. }\end{array}$ & $\begin{array}{l}\text { Less protective during transportation than Alternative } 2 \\
\text { because: } \\
\text { - More moves and lifts are required } \\
\text { - Greater transport distance is required } \\
\text { - Transport on DOE roadways, public roads, and railroads } \\
\text { - Exposure to workers and public is potentially greater because } \\
\text { the waste is transported from the INL using road systems with } \\
\text { potential public exposures along the entire travel route } \\
\text { - Increased mileage increases the risk of potential accidents. } \\
\text { Off-site at Hanford is more protective during transportation and } \\
\text { disposal than Alternative 1a because: } \\
\text { - Less moves and lifts are required } \\
\text { - Less transport distance is required. } \\
\text { Environmental risk at each disposal site will be similar since } \\
\text { each facility is approved under DOE O 435.1; however, Hanford } \\
\text { is in the process of writing a new EIS. }\end{array}$ & $\begin{array}{l}\text { More protective during transportation and } \\
\text { disposal than Alternative } 1 \mathrm{a} \text { and Alternative } 1 \mathrm{~b} \\
\text { because: } \\
\text { - Least amount of miles traveled reduces } \\
\text { transportation risks } \\
\text { - Due to limited travel miles, least potential } \\
\text { environmental risk } \\
\text { - Least exposure potential to the public as the } \\
\text { waste does not leave the INL site } \\
\text { - Exposure to workers is less because the } \\
\text { waste does not leave the INL site, has limited } \\
\text { travel distance and has least number of } \\
\text { moves and lifts. } \\
\text { Environmental risk at each disposal site will be } \\
\text { similar since each facility is approved under } \\
\text { DOE O } 435.1 \text {. }\end{array}$ \\
\hline & \multicolumn{3}{|c|}{ Ability to Achieve Transportation and Disposal Objectives } \\
\hline & $\begin{array}{l}\text { All alternatives are capable of meeting transportation } \\
\text { and disposal objectives. }\end{array}$ & $\begin{array}{l}\text { All alternatives are capable of meeting transportation and } \\
\text { disposal objectives. }\end{array}$ & $\begin{array}{l}\text { All alternatives are capable of meeting the } \\
\text { transportation and disposal objectives. }\end{array}$ \\
\hline
\end{tabular}


Table B-2-10. (continued).

\begin{tabular}{|c|c|c|c|}
\hline & $\begin{array}{c}\text { Alternative } 1 \text { a-Off-Site } \\
\text { Disposal at NTS }\end{array}$ & $\begin{array}{l}\text { Alternative } 1 \mathrm{~b} \text {-Off-Site } \\
\text { Disposal at Hanford }\end{array}$ & $\begin{array}{c}\text { Alternative } 2 \text { - On-Site } \\
\text { Disposal at a } \\
\text { New Disposal Facility }\end{array}$ \\
\hline \multirow{10}{*}{ 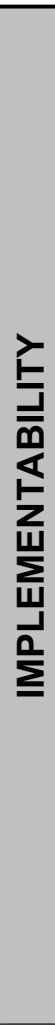 } & \multicolumn{3}{|l|}{ Technical Feasibility } \\
\hline & Technically feasible, but so are Alternatives 2 and $1 \mathrm{~b}$. & Technically feasible, but so are Alternatives 2 and $1 \mathrm{a}$. & $\begin{array}{l}\text { Technically feasible, but so are Alternatives } 1 \mathrm{a} \\
\text { and } 1 \mathrm{~b}\end{array}$ \\
\hline & \multicolumn{3}{|l|}{ Availability of Equipment } \\
\hline & $\begin{array}{l}\text { The equipment will need to be designed, developed, } \\
\text { tested, and implemented. The cask systems are not } \\
\text { expected to be available until } 2014 \text {. The NTS will be } \\
\text { available during the scheduled disposal period } \\
\text { through } 2027 \text {. From } 2027 \text { through } 2035 \text { the availability } \\
\text { is uncertain. All other equipment available at } \\
\text { generator and disposal site. }\end{array}$ & $\begin{array}{l}\text { The equipment will need to be designed, developed, tested, } \\
\text { and implemented. The cask systems are not expected to be } \\
\text { available until } 2014 \text {. All other equipment available at generator } \\
\text { and disposal site. }\end{array}$ & $\begin{array}{l}\text { All lifting and transport systems available on- } \\
\text { site. }\end{array}$ \\
\hline & \multicolumn{3}{|l|}{ Personnel Services } \\
\hline & $\begin{array}{l}\text { Subcontract personnel and facility personnel with } \\
\text { demonstrated performance will conduct the } \\
\text { transportation. Disposal facility personnel will perform } \\
\text { disposal. }\end{array}$ & $\begin{array}{l}\text { Subcontract personnel and facility personnel with demonstrated } \\
\text { performance will conduct the transportation. Disposal facility } \\
\text { personnel will perform disposal. }\end{array}$ & $\begin{array}{l}\text { Facility personnel with demonstrated } \\
\text { performance will conduct transportation and } \\
\text { disposal. }\end{array}$ \\
\hline & \multicolumn{3}{|l|}{ Disposal Facilities } \\
\hline & $\begin{array}{l}\text { More complicated to implement for transportation and } \\
\text { disposal action than Alternative } 2 \text { and Alternative } 1 \mathrm{~b} \\
\text { because: } \\
\text { - Off-site transportation is required complicating the } \\
\text { planning, approvals and scheduling } \\
\text { - Transportation includes dedicated transport system } \\
\text { (potential commercially leases) } \\
\text { - Longer schedule required to complete disposal } \\
\text { action } \\
\text { - Least operational experience with RH LLW } \\
\text { disposals } \\
\text { - Most number of shipments. }\end{array}$ & $\begin{array}{l}\text { More complicated to implement for transportation and disposal } \\
\text { action than Alternative } 2 \text { because: } \\
\text { - Off-site transportation is required complicating the planning, } \\
\text { approvals and scheduling } \\
\text { - Transportation includes dedicated transport system (potential } \\
\text { commercially leases) for both rail and road } \\
\text { - Longer schedule required to complete disposal action. } \\
\text { Alternative } 1 b \text { is less complicated to implement for } \\
\text { transportation and disposal action than Alternative 1a because: } \\
\text { - Fewer shipments. }\end{array}$ & $\begin{array}{l}\text { Less complicated to implement for } \\
\text { transportation and disposal than Alternative 1a } \\
\text { and 1b because: } \\
\text { - No off-site transportation required simplifying } \\
\text { the planning and scheduling } \\
\text { - Disposal completed in shortest time period } \\
\text { - No leased transport systems required } \\
\text { - Previous operational experience with RH } \\
\text { LLW disposals. }\end{array}$ \\
\hline & \multicolumn{3}{|l|}{ Administrative Feasibility } \\
\hline & $\begin{array}{l}\text { Waste expected to meet WAC or waste will be } \\
\text { accepted with a special PA. Environmental } \\
\text { Management operations at NTS are currently } \\
\text { scheduled through } 2027 .\end{array}$ & $\begin{array}{l}\text { Waste expected to meet WAC but EIS needs to be implement } \\
\text { prior to WAC implementation and DOE and State of } \\
\text { Washington must settle. Special PA may be required for some } \\
\text { wastes. Operations at Hanford are currently scheduled through } \\
2035 \text {. }\end{array}$ & $\begin{array}{l}\text { Waste expected to meet new disposal facility } \\
\text { WAC requiring no special PA. New disposal } \\
\text { facility life expected through } 2035 \text {. }\end{array}$ \\
\hline
\end{tabular}


Summarized, the differences are:

- Alternative 1a - Off-Site Disposal of RH LLW at NTS. This alternative incurs more worker and public risk than Alternative 2 and Alternative $1 \mathrm{~b}$ due to most travel miles and travel over public highways. This option will require more administrative and scheduling than Alternative 2 or Alternative $1 b$. NTS has less experience receiving RH LLW. This option is technically more complex due to the DOT requirements.

- Alternative 1b - Off-Site Disposal of RH LLW at Hanford. This alternative incurs more worker and public risk than Alternative 2 due to more travel miles and travel over railroads. This option will require more administrative and scheduling than Alternative 2 but less than Alternative 1a. Hanford has more experience receiving RH LLW than NTS. This option is currently not administratively feasible as a result of ongoing issues between the State of Washington and the DOE as well as the issuance of a new EIS.

- Alternative 2 - On-Site Disposal of RH LLW. This option has the least amount of public risk due to fewest travel miles, fewest number of moves and lifts, and no travel over public highways. This option has the least amount of worker risk because of the fewest travel miles.

\section{B-3. CONTACT-HANDLED LOW-LEVEL WASTE DISPOSAL SCREENING}

\section{B-3.1 Contact-Handled Low-Level Waste}

The alternatives presented in this section consider packaging, transportation, and disposal of CH LLW waste currently stored or generated at the INL Site. Contact-handled LLW is generally defined in disposal facility WACs for ALARA considerations; for instance, NTS considers waste packages with dose rates of up to $100 \mathrm{mR} / \mathrm{hr}$ at $30 \mathrm{~cm}$ as $\mathrm{CH}$ although the current on-site $\mathrm{CH}$ LLW disposal facility considers packages with up to $500 \mathrm{mR} / \mathrm{hr}$ at $1 \mathrm{~m}$ as contact handled. Because this report addresses potential disposal options at on-site and off-site LLW disposal facilities, for consistency we will define $\mathrm{CH}$ LLW as waste having a dose equivalent of less than $200 \mathrm{mrem} / \mathrm{hr}$ at contact. This corresponds to the U.S. Department of Transportation (DOT) limit above which waste must be shipped in an exclusive use vehicle (49 CFR 173.441). To get an idea of the characterization of INL Site CH LLW, examples of two typical waste streams are in Tables B-3-1 and B-3-2. Historically, small volumes of CH LLW have been disposed of off-site at both DOE and commercial disposal facilities.

There are several factors that affect the acceptance of CH LLW by off-site generators. CH LLW that is considered classified for national security reasons and can not be declassified is managed in accordance with the requirements of DOE M 473.1-1 and, DOE O 474.1, and cannot be received by commercial disposal facilities. In addition, waste containing accountable nuclear material, waste with fissile material, and waste containing special nuclear material are managed on a case-by-case basis, and in some cases must be disposed of at DOE-operated facilities. Consequently, some of the INL Site CH LLW will require disposal at NTS or other DOE-operated LLW disposal facility. 
Table B-3-1. Contact-handled low-level waste - Typical Profile \#1.

Waste Stream - Typical \#1 - INFORMATION ONLY

Fissile material present: NO

Total transuranic activity per gram of waste is less than $10 \mathrm{nCi} / \mathrm{g}$

Expected Radiation dose rate at surface: 0.01 to $200 \mathrm{mrem} / \mathrm{hr}$

Expected Radiation dose rate at $1 \mathrm{~m}: 0.01$ to $20 \mathrm{mrem} / \mathrm{hr}$

Composition: Any combination of cloth, paper, plastic, wood, and ferrous and nonferrous metal articles

Activity ranges all start at 0

Maximum activity range is listed

Not all constituents will be in waste on a container by container basis

\begin{tabular}{|c|c|c|c|c|c|c|c|c|c|c|c|c|c|c|}
\hline \multicolumn{3}{|c|}{ Transuranic } & \multicolumn{3}{|c|}{ U233 \& U235 } & \multicolumn{9}{|c|}{ Other } \\
\hline Isotope & \multicolumn{2}{|c|}{ Max range } & \multirow{2}{*}{$\begin{array}{l}\text { Isotope } \\
\text { U-233 }\end{array}$} & \multicolumn{2}{|c|}{ Max range } & \multirow{2}{*}{$\begin{array}{l}\text { Isotope } \\
\text { Ac- } 255\end{array}$} & \multicolumn{2}{|c|}{ Max range } & \multirow{2}{*}{$\begin{array}{l}\text { Isotope } \\
\mathrm{H}-3\end{array}$} & \multicolumn{2}{|c|}{ Max range } & \multirow{2}{*}{$\begin{array}{l}\text { Isotope } \\
\text { Ru-106 }\end{array}$} & \multicolumn{2}{|c|}{ Max range } \\
\hline $\mathrm{Am}-241$ & $8.70 \mathrm{E}+00$ & $\mathrm{nCi} / \mathrm{g}$ & & $6.82 \mathrm{E}-10$ & $\mathrm{nCi} / \mathrm{g}$ & & $5.09 \mathrm{E}-12$ & $\mathrm{Ci} / \mathrm{m} 3$ & & $1.00 \mathrm{E}-02$ & $\mathrm{Ci} / \mathrm{m} 3$ & & $3.94 \mathrm{E}-02$ & $\mathrm{Ci} / \mathrm{m} 3$ \\
\hline $\mathrm{Am}-242$ & $1.13 \mathrm{E}-07$ & $\mathrm{nCi} / \mathrm{g}$ & U-235 & $4.00 \mathrm{E}-02$ & $\mathrm{nCi} / \mathrm{g}$ & Ac- 227 & $3.11 \mathrm{E}-08$ & $\mathrm{Ci} / \mathrm{m} 3$ & Ho-166m & 4.03E-09 & $\mathrm{Ci} / \mathrm{m} 3$ & Sb-125 & $2.66 \mathrm{E}-01$ & $\mathrm{Ci} / \mathrm{m} 3$ \\
\hline $\mathrm{Am}-242 \mathrm{~m}$ & $1.13 \mathrm{E}-07$ & $\mathrm{nCi} / \mathrm{g}$ & & & & Ac- 228 & $1.06 \mathrm{E}-13$ & $\mathrm{Ci} / \mathrm{m} 3$ & I- 129 & $4.00 \mathrm{E}+01$ & $\mathrm{Ci} / \mathrm{m} 3$ & Sb-126 & $3.64 \mathrm{E}-04$ & $\mathrm{Ci} / \mathrm{m} 3$ \\
\hline Am-243 & $6.44 \mathrm{E}-09$ & $\mathrm{nCi} / \mathrm{g}$ & & & & $\mathrm{Ag}-108$ & $3.35 \mathrm{E}-10$ & $\mathrm{Ci} / \mathrm{m} 3$ & $\mathrm{Nb}-93 \mathrm{~m}$ & $9.88 \mathrm{E}-04$ & $\mathrm{Ci} / \mathrm{m} 3$ & $\mathrm{Sb}-126 \mathrm{~m}$ & $5.09 \mathrm{E}-05$ & $\mathrm{Ci} / \mathrm{m} 3$ \\
\hline $\mathrm{Cm}-242$ & $9.10 \mathrm{E}-09$ & $\mathrm{nCi} / \mathrm{g}$ & & & & $\mathrm{Ag}-110$ & $3.56 \mathrm{E}-09$ & $\mathrm{Ci} / \mathrm{m} 3$ & $\mathrm{Nb}-94$ & $8.00 \mathrm{E}-02$ & $\mathrm{Ci} / \mathrm{m} 3$ & $\mathrm{Se}-79$ & $4.11 \mathrm{E}-04$ & $\mathrm{Ci} / \mathrm{m} 3$ \\
\hline $\mathrm{Cm}-243$ & $2.92 \mathrm{E}-09$ & $\mathrm{nCi} / \mathrm{g}$ & & & & $\mathrm{Ag}-110 \mathrm{~m}$ & $2.66 \mathrm{E}-07$ & $\mathrm{Ci} / \mathrm{m} 3$ & $\mathrm{Ni}-59$ & $7.00 \mathrm{E}-02$ & $\mathrm{Ci} / \mathrm{m} 3$ & Sm-147 & $2.28 \mathrm{E}-08$ & $\mathrm{Ci} / \mathrm{m} 3$ \\
\hline $\mathrm{Cm}-244$ & $5.10 \mathrm{E}+02$ & $\mathrm{nCi} / \mathrm{g}$ & & & & $\mathrm{Ba}-137 \mathrm{~m}$ & $7.29 \mathrm{E}-01$ & $\mathrm{Ci} / \mathrm{m} 3$ & Ni-63 & $7.00 \mathrm{E}+00$ & $\mathrm{Ci} / \mathrm{m} 3$ & $\mathrm{Sm}-151$ & $1.21 \mathrm{E}-01$ & $\mathrm{Ci} / \mathrm{m} 3$ \\
\hline $\mathrm{Cm}-245$ & $5.31 \mathrm{E}-13$ & $\mathrm{nCi} / \mathrm{g}$ & & & & Be-10 & $1.40 \mathrm{E}+01$ & $\mathrm{Ci} / \mathrm{m} 3$ & $\mathrm{~Pa}-231$ & $1.36 \mathrm{E}-07$ & $\mathrm{Ci} / \mathrm{m} 3$ & Sn-119m & $5.85 \mathrm{E}-04$ & $\mathrm{Ci} / \mathrm{m} 3$ \\
\hline $\mathrm{Cm}-246$ & $8.34 \mathrm{E}-15$ & $\mathrm{nCi} / \mathrm{g}$ & & & & $\mathrm{Bi}-207$ & $2.97 \mathrm{E}+00$ & $\mathrm{Ci} / \mathrm{m} 3$ & $\mathrm{~Pa}-233$ & 4.17E-04 & $\mathrm{Ci} / \mathrm{m} 3$ & Sn- $121 \mathrm{~m}$ & $7.53 \mathrm{E}-05$ & $\mathrm{Ci} / \mathrm{m} 3$ \\
\hline $\mathrm{Cm}-248$ & $1.70 \mathrm{E}-01$ & $\mathrm{nCi} / \mathrm{g}$ & & & & $\mathrm{Bi}-210$ & $9.88 \mathrm{E}-12$ & $\mathrm{Ci} / \mathrm{m} 3$ & $\mathrm{~Pa}-234$ & $2.20 \mathrm{E}-10$ & $\mathrm{Ci} / \mathrm{m} 3$ & Sn-126 & $3.64 \mathrm{E}-04$ & $\mathrm{Ci} / \mathrm{m} 3$ \\
\hline Np-237 & $6.10 \mathrm{E}+00$ & $\mathrm{nCi} / \mathrm{g}$ & & & & $\mathrm{Bi}-212$ & $1.59 \mathrm{E}-07$ & $\mathrm{Ci} / \mathrm{m} 3$ & $\mathrm{~Pb}-210$ & $5.09 \mathrm{E}-12$ & $\mathrm{Ci} / \mathrm{m} 3$ & Sr-90 & $4.80 \mathrm{E}+00$ & $\mathrm{Ci} / \mathrm{m} 3$ \\
\hline Np-239 & $6.44 \mathrm{E}-09$ & $\mathrm{nCi} / \mathrm{g}$ & & & & $\mathrm{Bi}-213$ & $5.09 \mathrm{E}-12$ & $\mathrm{Ci} / \mathrm{m} 3$ & $\mathrm{~Pb}-211$ & $1.55 \mathrm{E}-13$ & $\mathrm{Ci} / \mathrm{m} 3$ & Tc-99 & $3.00 \mathrm{E}+00$ & $\mathrm{Ci} / \mathrm{m} 3$ \\
\hline $\mathrm{Pu}-236$ & $1.82 \mathrm{E}-06$ & $\mathrm{nCi} / \mathrm{g}$ & & & & C-14 & $8.00 \mathrm{E}+00$ & $\mathrm{Ci} / \mathrm{m} 3$ & $\mathrm{~Pb}-212$ & $1.59 \mathrm{E}-07$ & $\mathrm{Ci} / \mathrm{m} 3$ & $\mathrm{Te}-125 \mathrm{~m}$ & $7.59 \mathrm{E}-02$ & $\mathrm{Ci} / \mathrm{m} 3$ \\
\hline $\mathrm{Pu}-238$ & $4.17 \mathrm{E}+00$ & $\mathrm{nCi} / \mathrm{g}$ & & & & Cd-113 & $6.62 \mathrm{E}-06$ & $\mathrm{Ci} / \mathrm{m} 3$ & $\mathrm{~Pb}-214$ & $1.82 \mathrm{E}-11$ & $\mathrm{Ci} / \mathrm{m} 3$ & Th-227 & $3.03 \mathrm{E}-08$ & $\mathrm{Ci} / \mathrm{m} 3$ \\
\hline $\mathrm{Pu}-239$ & $7.70 \mathrm{E}+00$ & $\mathrm{nCi} / \mathrm{g}$ & & & & $\mathrm{Cd}-113 \mathrm{~m}$ & $6.62 \mathrm{E}-03$ & $\mathrm{Ci} / \mathrm{m} 3$ & Pd-107 & $1.52 \mathrm{E}-05$ & $\mathrm{Ci} / \mathrm{m} 3$ & Th-228 & $1.59 \mathrm{E}-07$ & $\mathrm{Ci} / \mathrm{m} 3$ \\
\hline $\mathrm{Pu}-240$ & 4.93E-02 & $\mathrm{nCi} / \mathrm{g}$ & & & & $\mathrm{Ce}-144$ & $5.32 \mathrm{E}-02$ & $\mathrm{Ci} / \mathrm{m} 3$ & $\mathrm{Pm}-146$ & $8.35 \mathrm{E}-05$ & $\mathrm{Ci} / \mathrm{m} 3$ & Th-229 & $5.12 \mathrm{E}-12$ & $\mathrm{Ci} / \mathrm{m} 3$ \\
\hline $\mathrm{Pu}-241$ & $4.93 \mathrm{E}+00$ & $\mathrm{nCi} / \mathrm{g}$ & & & & $\mathrm{Cl}-36$ & $2.97 \mathrm{E}-01$ & $\mathrm{Ci} / \mathrm{m} 3$ & Pm-147 & $6.38 \mathrm{E}-01$ & $\mathrm{Ci} / \mathrm{m} 3$ & Th-230 & $1.50 \mathrm{E}-02$ & $\mathrm{Ci} / \mathrm{m} 3$ \\
\hline $\mathrm{Pu}-242$ & $1.10 \mathrm{E}-04$ & $\mathrm{nCi} / \mathrm{g}$ & & & & Co-60 & $7.00 \mathrm{E}+00$ & $\mathrm{Ci} / \mathrm{m} 3$ & Po-210 & $7.29 \mathrm{E}-13$ & $\mathrm{Ci} / \mathrm{m} 3$ & Th-231 & $3.41 \mathrm{E}-06$ & $\mathrm{Ci} / \mathrm{m} 3$ \\
\hline \multirow[t]{9}{*}{$\mathrm{Pu}-244$} & $1.93 \mathrm{E}-17$ & $\mathrm{nCi} / \mathrm{g}$ & & & & Cs-134 & $4.11 \mathrm{E}-01$ & $\mathrm{Ci} / \mathrm{m} 3$ & Pr-144 & $5.32 \mathrm{E}-02$ & $\mathrm{Ci} / \mathrm{m} 3$ & Th-232 & $2.05 \mathrm{E}-07$ & $\mathrm{Ci} / \mathrm{m} 3$ \\
\hline & & & & & & Cs- 135 & $8.35 \mathrm{E}-04$ & $\mathrm{Ci} / \mathrm{m} 3$ & $\mathrm{Ra}-223$ & $1.06 \mathrm{E}-07$ & $\mathrm{Ci} / \mathrm{m} 3$ & Th-234 & $1.67 \mathrm{E}-07$ & $\mathrm{Ci} / \mathrm{m} 3$ \\
\hline & & & & & & Cs- 137 & $3.10 \mathrm{E}+00$ & $\mathrm{Ci} / \mathrm{m} 3$ & $\mathrm{Ra}-224$ & $1.59 \mathrm{E}-07$ & $\mathrm{Ci} / \mathrm{m} 3$ & $\mathrm{U}-232$ & $2.66 \mathrm{E}-08$ & $\mathrm{Ci} / \mathrm{m} 3$ \\
\hline & & & & & & Eu-152 & $4.20 \mathrm{E}+03$ & $\mathrm{ci} / \mathrm{m} 3$ & $\mathrm{Ra}-225$ & $5.09 \mathrm{E}-12$ & $\mathrm{ci} / \mathrm{m} 3$ & U-234 & $3.50 \mathrm{E}-02$ & $\mathrm{ci} / \mathrm{m} 3$ \\
\hline & & & & & & Eu-154 & $4.70 \mathrm{E}-01$ & $\mathrm{ci} / \mathrm{m} 3$ & $\mathrm{Ra}-226$ & $1.82 \mathrm{E}-11$ & $\mathrm{ci} / \mathrm{m} 3$ & U-236 & $9.12 \mathrm{E}-06$ & $\mathrm{ci} / \mathrm{m} 3$ \\
\hline & & & & & & Eu-155 & $7.15 \mathrm{E}-03$ & $\mathrm{ci} / \mathrm{m} 3$ & $\mathrm{Ra}-228$ & $1.06 \mathrm{E}-13$ & $\mathrm{ci} / \mathrm{m} 3$ & U-237 & $2.43 \mathrm{E}-05$ & $\mathrm{ci} / \mathrm{m} 3$ \\
\hline & & & & & & $\mathrm{Fe}-55$ & $7.00 \mathrm{E}+00$ & $\mathrm{ci} / \mathrm{m} 3$ & $\mathrm{Rb}-87$ & $2.81 \mathrm{E}-08$ & $\mathrm{ci} / \mathrm{m} 3$ & U-238 & $4.00 \mathrm{E}-02$ & $\mathrm{ci} / \mathrm{m} 3$ \\
\hline & & & & & & Gd-152 & $7.53 \mathrm{E}-16$ & $\mathrm{ci} / \mathrm{m} 3$ & Rh-102 & $3.73 \mathrm{E}-06$ & $\mathrm{ci} / \mathrm{m} 3$ & Y-90 & $7.38 \mathrm{E}-01$ & $\mathrm{ci} / \mathrm{m} 3$ \\
\hline & & & & & & & & & Rh-106 & $3.94 \mathrm{E}-02$ & $\mathrm{ci} / \mathrm{m} 3$ & $\mathrm{Zr}-93$ & $2.10 \mathrm{E}-03$ & $\mathrm{ci} / \mathrm{m} 3$ \\
\hline
\end{tabular}


Table B-3-2. Contact-Handled low-level waste - Typical Profile \#2.

Waste Stream - Typical \#2 - INFORMATION ONLY

Fissile material present: NO

Total transuranic activity per gram of waste is less than $10 \mathrm{nCi} / \mathrm{g}$

Expected Radiation dose rate at surface: 0 to $200 \mathrm{mrem} / \mathrm{hr}$

Expected Radiation dose rate at $1 \mathrm{~m}: 0$ to $10 \mathrm{mrem} / \mathrm{hr}$

Composition: Any combination of cloth, paper, plastic, wood, and ferrous and nonferrous metal articles

Activity ranges all start at 0

Maximum activity range is listed

Not all constituents will be in waste on a container by container basis

\begin{tabular}{|c|c|c|c|c|c|c|c|c|c|c|c|}
\hline \multicolumn{2}{|c|}{ Transuranic } & \multicolumn{2}{|c|}{ U233 \& U235 } & \multicolumn{8}{|c|}{ Other } \\
\hline Isotope & Max range & \multirow{2}{*}{$\begin{array}{c}\text { Isotope } \\
\text { U-233 }\end{array}$} & Max range & \multirow{2}{*}{$\begin{array}{l}\text { Isotope } \\
\text { Ba-137m }\end{array}$} & Max range & \multirow{2}{*}{$\begin{array}{l}\text { Isotope } \\
\text { Nb-93m }\end{array}$} & \multicolumn{2}{|c|}{ Max range } & \multirow{2}{*}{$\begin{array}{l}\text { Isotope } \\
\text { Se-79 }\end{array}$} & \multicolumn{2}{|c|}{ Max range } \\
\hline Am-241 & $1.00 \mathrm{E}+01 \mathrm{nCi} / \mathrm{g}$ & & $1.00 \mathrm{E}+01 \mathrm{nCi} / \mathrm{g}$ & & $1.00 \mathrm{E}+02 \mathrm{nCi} / \mathrm{g}$ & & $1.00 \mathrm{E}+02$ & $\mathrm{nCi} / \mathrm{g}$ & & $1.00 \mathrm{E}+02$ & $\mathrm{nCi} / \mathrm{g}$ \\
\hline Am-242 & $1.00 \mathrm{E}+01 \mathrm{nCi} / \mathrm{g}$ & U-235 & $1.00 \mathrm{E}+01 \mathrm{nCi} / \mathrm{g}$ & C-14 & $1.00 \mathrm{E}+02 \mathrm{nCi} / \mathrm{g}$ & $\mathrm{Nb}-94$ & $1.00 \mathrm{E}+02$ & $\mathrm{nCi} / \mathrm{g}$ & Sm-151 & $1.00 \mathrm{E}+02$ & $\mathrm{nCi} / \mathrm{g}$ \\
\hline Am-242m & $1.00 \mathrm{E}+01 \mathrm{nCi} / \mathrm{g}$ & & & Cd-113 & $1.00 \mathrm{E}+02 \mathrm{nCi} / \mathrm{g}$ & Ni-59 & $1.00 \mathrm{E}+02$ & $\mathrm{nCi} / \mathrm{g}$ & $\mathrm{Sn}-121 \mathrm{~m}$ & $1.00 \mathrm{E}+02$ & $\mathrm{nCi} / \mathrm{g}$ \\
\hline Am-243 & $1.00 \mathrm{E}+01 \mathrm{nCi} / \mathrm{g}$ & & & Cd-113m & $1.00 \mathrm{E}+02 \mathrm{nCi} / \mathrm{g}$ & $\mathrm{Ni}-63$ & $1.00 \mathrm{E}+02$ & $\mathrm{nCi} / \mathrm{g}$ & Sn-126 & $1.00 \mathrm{E}+02$ & $\mathrm{nCi} / \mathrm{g}$ \\
\hline $\mathrm{Cm}-242$ & $1.00 \mathrm{E}+01 \mathrm{nCi} / \mathrm{g}$ & & & $\mathrm{Ce}-144$ & $1.00 \mathrm{E}+02 \mathrm{nCi} / \mathrm{g}$ & $\mathrm{Pa}-233$ & $1.00 \mathrm{E}+02$ & $\mathrm{nCi} / \mathrm{g}$ & Sr-90 & $1.00 \mathrm{E}+02$ & $\mathrm{nCi} / \mathrm{g}$ \\
\hline $\mathrm{Cm}-243$ & $1.00 \mathrm{E}+01 \mathrm{nCi} / \mathrm{g}$ & & & Co-60 & $1.00 \mathrm{E}+02 \mathrm{nCi} / \mathrm{g}$ & $\mathrm{Pa}-234 \mathrm{~m}$ & $1.00 \mathrm{E}+02$ & $\mathrm{nCi} / \mathrm{g}$ & Tc-99 & $1.00 \mathrm{E}+02$ & $\mathrm{nCi} / \mathrm{g}$ \\
\hline Np-237 & $1.00 \mathrm{E}+01 \mathrm{nCi} / \mathrm{g}$ & & & Cs-134 & $1.00 \mathrm{E}+02 \mathrm{nCi} / \mathrm{g}$ & Pd-107 & $1.00 \mathrm{E}+02$ & $\mathrm{nCi} / \mathrm{g}$ & $\mathrm{Te}-125 \mathrm{~m}$ & $1.00 \mathrm{E}+02$ & $\mathrm{nCi} / \mathrm{g}$ \\
\hline $\mathrm{Pu}-236$ & $1.00 \mathrm{E}+01 \mathrm{nCi} / \mathrm{g}$ & & & Cs-135 & $1.00 \mathrm{E}+02 \mathrm{nCi} / \mathrm{g}$ & Pm-147 & $1.00 \mathrm{E}+02$ & $\mathrm{nCi} / \mathrm{g}$ & Th-231 & $1.00 \mathrm{E}+02$ & $\mathrm{nCi} / \mathrm{g}$ \\
\hline $\mathrm{Pu}-238$ & $1.00 \mathrm{E}+01 \mathrm{nCi} / \mathrm{g}$ & & & Cs-137 & $1.00 \mathrm{E}+03 \mathrm{nCi} / \mathrm{g}$ & Pr-144 & $1.00 \mathrm{E}+02$ & $\mathrm{nCi} / \mathrm{g}$ & Th-234 & $1.00 \mathrm{E}+02$ & $\mathrm{nCi} / \mathrm{g}$ \\
\hline $\mathrm{Pu}-239$ & $1.00 \mathrm{E}+01 \mathrm{nCi} / \mathrm{g}$ & & & Eu-152 & $1.00 \mathrm{E}+01 \mathrm{nCi} / \mathrm{g}$ & $\operatorname{Pr}-144 m$ & $1.00 \mathrm{E}+02$ & $\mathrm{nCi} / \mathrm{g}$ & $\mathrm{U}-234$ & $1.00 \mathrm{E}+02$ & $\mathrm{nCi} / \mathrm{g}$ \\
\hline $\mathrm{Pu}-240$ & $1.00 \mathrm{E}+01 \mathrm{nCi} / \mathrm{g}$ & & & Eu-154 & $1.00 \mathrm{E}+02 \mathrm{nCi} / \mathrm{g}$ & Ra-226 & $1.00 \mathrm{E}+02$ & $\mathrm{nCi} / \mathrm{g}$ & $\mathrm{U}-236$ & $1.00 \mathrm{E}+02$ & $\mathrm{nCi} / \mathrm{g}$ \\
\hline $\mathrm{Pu}-241$ & $1.50 \mathrm{E}+02 \mathrm{nCi} / \mathrm{g}$ & & & Eu-155 & $1.00 \mathrm{E}+02 \mathrm{nCi} / \mathrm{g}$ & Rh-106 & $1.00 \mathrm{E}+02$ & $\mathrm{nCi} / \mathrm{g}$ & $\mathrm{U}-237$ & $1.00 \mathrm{E}+02$ & $\mathrm{nCi} / \mathrm{g}$ \\
\hline \multirow[t]{4}{*}{$\mathrm{Pu}-242$} & $1.00 \mathrm{E}+01 \mathrm{nCi} / \mathrm{g}$ & & & $\mathrm{Fe}-55$ & $1.00 \mathrm{E}+02 \mathrm{nCi} / \mathrm{g}$ & $\mathrm{Ru}-106$ & $1.00 \mathrm{E}+02$ & $\mathrm{nCi} / \mathrm{g}$ & $\mathrm{U}-238$ & $1.00 \mathrm{E}+02$ & $\mathrm{nCi} / \mathrm{g}$ \\
\hline & & & & $\mathrm{H}-3$ & $1.00 \mathrm{E}+02 \mathrm{nCi} / \mathrm{g}$ & $\mathrm{Sb}-125$ & $1.00 \mathrm{E}+02$ & $\mathrm{nCi} / \mathrm{g}$ & $Y-90$ & $1.00 \mathrm{E}+02$ & $\mathrm{nCi} / \mathrm{g}$ \\
\hline & & & & $\mathrm{I}-129$ & $1.00 \mathrm{E}+02 \mathrm{nCi} / \mathrm{g}$ & $\mathrm{Sb}-126$ & $1.00 \mathrm{E}+02$ & $\mathrm{nCi} / \mathrm{g}$ & $\mathrm{Zr}-93$ & $1.00 \mathrm{E}+02$ & $\mathrm{nCi} / \mathrm{g}$ \\
\hline & & & & $\mathrm{Kr}-85$ & $1.00 \mathrm{E}+02 \mathrm{nCi} / \mathrm{g}$ & $\mathrm{Sb}-126 \mathrm{~m}$ & $1.00 \mathrm{E}+02$ & $\mathrm{nCi} / \mathrm{g}$ & $\mathrm{Zr}-95$ & $1.00 \mathrm{E}+02$ & $\mathrm{nCi} / \mathrm{g}$ \\
\hline
\end{tabular}




\section{B-3.1.1 CH LLW Disposal Assumptions and Initial Screening}

Assumptions were formulated to permit disposal options analysis. The assumptions are as follows:

- $\quad$ The CH LLW is ubiquitously generated at most INL facilities.

- CH LLW has dose rates that meet the disposal facility WAC.

- CH LLW is packaged in containers meeting the disposal facility's package criteria.

- For ease of calculating shipment, each shipment will consist of a standard $8^{\prime} \times 8^{\prime} \times 20^{\prime}$ metal cargo container $\left(36 \mathrm{~m}^{3}\right)$. (Note: Accepted container types vary by disposal facility but most packaging at the INL with exception of wooden containers meet packaging requirements at disposal facilities so standard operations at INL facilities are not expected to differ from present.)

- $\quad$ The waste packages will be disposed FY 2009-2035.

- Generators prepares package and places it on the over-the-road transport.

- Radiological characterization information is based on best available information.

- The June 2006 disposal facility WACs are assumed to remain unchanged and provide the criteria governing disposals.

- The waste package and transport system will comply with DOT (off-site transport) and transport plan (on-site transport).

\section{B-3.1.2 Disposal of CH LLW at an On Site Disposal Facility}

B-3.1.2.1 Radioactive Waste Management Complex (RWMC)—The LLW pit at the RWMC, slated to close to CH LLW at the end of FY 2008, provides the final resting place for more than $4,000 \mathrm{~m}^{3}$ of CH LLW annually. The LLW is currently being filled at an accelerated rate due to the increased efforts of the Idaho Cleanup Project and as a result, the pit may fill to capacity before the end of FY 2008. CH LLW will need to be disposed elsewhere when the pit fills to capacity or at the end of FY 2008. RWMC is not considered a viable option for continued CH LLW disposal and will not be evaluated further.

B-3.1.2.2 Idaho CERCLA Disposal Facility (ICDF)-The ICDF is an on-site disposal facility that accepts only CERCLA waste generated at the INL. Approximately $4,000 \mathrm{~m}^{3}$ of INL generated CH LLW is not CERCLA generated and therefore the ICDF is not considered a viable option for that portion of CH LLW, and so the ICDF will not be evaluated further.

B-3.1.2.3 New On-site Disposal Facility-The concept for a new on-site disposal facility accepts all LLW. The CH LLW would be disposed of at the new facility once it is operational. The waste would be transported via DOT standards or use an on-site transport plan. The new on-site LLW disposal facility, although in an early pre-conceptual planning stage, is considered a viable option and will be further evaluated. 


\section{B-3.1.3 Disposal of CH LLW at an Off-Site Disposal Facility}

For this alternative, the CH LLW debris would be disposed at an off-site facility. Eight off-site facilities are evaluated to satisfy this alternative. Of the eight, one will be selected for use in the alternative analysis. The options evaluation will be based principally on waste acceptance at the disposal facility; however, a cursory cost evaluation for disposal rates at four facilities are listed in Table B-3-3 to discern rough order of magnitude costs.

Table B-3-3. Estimated disposal rate cost for one year of disposal.

\begin{tabular}{cc}
\hline Off-Site LLW Disposal facility & $\begin{array}{c}\text { Estimated Disposal Cost for "Typical” INL CH LLW } \\
\left(4,000 \mathrm{~m}^{3}, 110 \text { containers, } 110 \text { shipment, }<200 \mathrm{mR} / \mathrm{hr}\right)\end{array}$ \\
\hline NTS & $\$ 1,844,594$ \\
EnergySolutions & $\$ 2,577,489$ \\
Hanford & $\$ 2,781,016$ \\
U.S. Ecology & $\$ 16,221,363$ \\
\hline
\end{tabular}

B-3.1.3.1 DOE Disposal at Nevada Test Site in Nevada. This option would transport and dispose of the CH LLW at NTS. The logistics for moving the CH LLW would be to use the existing package configurations and load the packages onto standard DOT compliant truck transport. The transportation support does exist to move the waste package from the INL to NTS. NTS contact handles waste packages up to $100 \mathrm{mR} / \mathrm{hr}$ at $30 \mathrm{~cm}$, dose rates above that are considered $\mathrm{RH}$. The waste is considered routine at the point of generation and at the point of disposal so does not presents any technical challenges in meeting the waste acceptance at NTS. NTS is considered a viable option.

B-3.1.3.2 DOE Disposal at Hanford in Washington. This option would transport and dispose of the CH LLW at DOE Hanford.

One major unresolved issue complicates disposal at Hanford. The DOE settled their lawsuit with the state of Washington on storing of untreated mixed transuranic waste by agreeing to halt shipments of LLW until a new environmental review is complete. This effectively prohibits the Hanford site from further disposal of out-of-state DOE-generated LLW until the EIS is complete.

The logistics for moving the CH LLW would be to use the existing package configurations and load the packages onto standard DOT compliant truck transport. The transportation support does exist to move the waste package from the INL to Hanford. Hanford contact handles waste packages with dose rates less than or equal to $200 \mathrm{mr} / \mathrm{hr}$ at contact and less than $100 \mathrm{mR} / \mathrm{hr}$ at $30 \mathrm{~cm}$. The waste is considered routine at the point of generation and at the point of disposal so does not presents any technical challenges in meeting the waste acceptance at Hanford.

Though the waste meets the initial screening criteria for transporting to and disposal at DOE Hanford, the unresolved issues prevents Hanford from accepting any INL LLW. This option is considered not to be viable until issues have been resolved and will not be evaluated further in the analysis of options sections. 
B-3.1.3.3 DOE Disposal at Oak Ridge, Tennessee. The DOE disposal facility in Oak Ridge, Tennessee cannot receive off-site LLW. Therefore, this option is screened out from further evaluation.

B-3.1.3.4 DOE Disposal at SRS, South Carolina. The DOE disposal facility in South Carolina includes engineered vaults and trenches. SRS receives only waste from on-site and activated metal components generated by the Navy. Because SRS cannot receive the CH LLW, this option is screened out from further evaluation.

B-3.1.3.5 Commercial Disposal at Barnwell, South Carolina. Barnwell, South Carolina is a commercial disposal facility considered as a disposal option. The logistics for moving the CH LLW would be to use the existing package configurations and load the packages onto standard DOT compliant truck transport. The transportation support does exist to move the waste package from the INL to Barnwell. The waste is considered routine at the point of generation and at the point of disposal so does not present any technical challenges in meeting the waste acceptance at Barnwell. At the beginning of 2008, Barnwell is scheduled to enter into a compact with three Eastern states and at that time, the site will receive waste from only the compact states, so this option is screened out from further evaluation.

B-3.1.3.6 Commercial Disposal at U. S. Ecology in Hanford, Washington. This option would transport and dispose of the CH LLW at the U.S. Ecology facility at Hanford, Washington. The logistics for moving the CH LLW would be to use the existing package configurations and load the packages onto standard DOT compliant truck transport. The transportation support does exist to move the waste package from the INL to U.S. Ecology. The waste is considered routine at the point of generation. Although U.S. Ecology disposal is qualifiedly viable, not all the waste will meet the WAC, the waste may be rejected entirely, and another option will need to be selected at the very minimum to accommodate rejected waste. U.S. Ecology is a consideration, but will not be evaluated further in the analysis of options section.

B-3.1.3.7 Commercial Disposal at Waste Control Specialists in Texas. WCS, in Texas, is a commercial disposal facility considered as a disposal option. WCS is in the process of applying for a NRC license to accept Class A, B, and C LLW and do not anticipate receiving a license until after 2007. As of June 5, the Texas Commission on Environmental Quality expressed doubt extensive technical concerns about the company's license application, which may result in postponement of the license (Weapons Complex Monitor 2006). WCS does not have a published WAC; however, when the CH LLW is compared against the WCS license application, no immediate acceptance issues are indicated. From a schedule standpoint WCS may be a future option for CH LLW disposal and as such will be reassessed after WCS attains licensing. However, without a license, a cost schedule, or WAC, this disposal facility does not have enough information to evaluate against other available options and so is screened out from further evaluation. Texas law requires that ownership of the Federal waste portion of the WCS facility revert to the Federal government at the completion of waste receipt operations. DOE has not yet decided whether disposal under these conditions is acceptable, given that DOE might eventually have to take back the site.

B-3.1.3.8 Commercial Disposal at EnergySolutions in Utah. EnergySolutions (formerly Envirocare of Utah) is a commercial disposal facility considered as a disposal option. EnergySolutions is limited to accepting only NRC Class A waste. Most of the CH LLW will meet the NRC Class A designation. The logistics for moving the CH LLW would be to use the existing package configurations and load the packages onto standard DOT compliant truck transport. The transportation support does exist to move the waste package from the INL to EnergySolutions. The waste is considered routine at the point of generation. EnergySolutions disposal is qualifiedly viable since not all the waste will meet the WAC. Another option will need to be selected at the very minimum to accommodate rejected waste. This option is a consideration but will not be used for the alternative evaluation. 


\section{B-3.1.4 Analysis of Viable Disposal Options}

Both on-site and off-site disposal facilities were initially screened for viability. Consideration has been given for selection of both DOE operated disposal facilities and commercially operated disposal facilities. If the INL generators instituted a sort, segregate, and package program to strictly adhere to the disposal facilities limits, the commercially operated facilities can accept most of the CH-LLW. However, due to the unique missions at the INL, certification for at least one DOE operated facility is required to maintain the capability to dispose of all the LLW generated. Optimally, the INL will utilize a combination of all available disposal options to achieve a cost effective LLW disposal program, but for this effort the two viable disposal options compared are a new on-site disposal facility and NTS.

B-3.1.4.1 Disposal of the CH LLW at New On-site Disposal Facility. The concept for a new on-site disposal facility accepts all LLW. Part of the design considerations for a new LLW disposal facility would include the characteristics of the CH LLW and the long-term performance and monitoring requirements.

\section{Protectiveness}

This option would be protective of public health, the community, and the environment during transportation to and disposal at a new on-site disposal facility. The waste would not leave the INL or use public highways resulting in the lowest transportation risk with the fewest miles of travel. Adhering to on-site transport plans and meeting the WAC and operational requirements at the new disposal facility will protect worker exposure. This option is protective of the environment, as the disposal facility will be designed to be compliant with all applicable nuclear safety operational and disposal regulations.

\section{Ability to Achieve Objectives}

This option would continue to store the CH LLW in a compliant manner at generator facilities or off-site disposal until the new disposal facility is operational. As the new facility would specifically incorporate the CH LLW as a waste type requiring disposal, no special assessments for long-term disposal would need to be completed. This option would achieve the objective for waste disposal.

\section{Technical Feasibility}

CH LLW disposal at a new on-site disposal facility is technically feasible. Construction of a new disposal facility would be based on an existing LLW disposal facility design and incorporated requirements applicable for the safe disposal of the waste.

\section{Availability of Equipment, Personnel, and Disposal Facilities}

Transportation methods and disposal the waste could be handled in a safe and routine manner using equipment, procedures, and personnel available but modified for the new on-site disposal facility. The availability of the disposal facility will be dependent on such details as the location studies, approval processes, construction schedule, and operational readiness reviews.

\section{Administrative Feasibility}

A new on-site disposal facility would incorporate the waste handling, storage, transportation, waste acceptance, disposal, and long-term monitoring for the CH LLW debris. This option is administratively feasible. 


\section{B-3.1.4.2 Disposal of the CH LLW at NTS}

\section{Protectiveness}

Disposal of the CH LLW at NTS would be protective of public health, the community, and the environment during transportation to and disposal at NTS. This option requires the waste to be transported in compliance with DOT requirements. This option results in the most miles traveled with transport over the public highway system with increases in the associated transportation risks. This option would meet the NTS WAC and is protective of the environment as the disposal facility is compliant with DOE Order 435.1.

\section{Ability to Achieve Objectives}

This option would achieve the objectives for transportation and disposal of the waste package by following DOT regulations and by compliance with the NTS WAC.

\section{Implementation}

Based on the criteria, disposal at NTS is implementable.

\section{Technical Feasibility}

This option is technically feasible. Transportation methods to and disposal of the waste at NTS are currently not routine but are achievable. The waste would be transported using DOT compliant packaging. No shipments will involve special DOT permitting.

\section{Availability of Equipment, Personnel, and Disposal Facilities}

The equipment and personnel necessary to complete the transportation and disposal is available. The NTS will continue to be available during the scheduled disposal period.

\section{Administrative Feasibility}

Disposal of the waste at NTS is administratively feasible. The waste is expected to be compliant with the NTS WAC. Packaging and transportation will compliant with the DOT requirements. The transportation and disposal schedule is complicated by off-site transportation over public highways.

\section{B-3.1.5 Comparative Analysis of the Disposal Options}

Ten disposal options were initially identified and evaluated to select two viable options. Two viable options were further evaluated for effectiveness, implementability, and costs for analysis of alternatives of the CH LLW. The option for CH LLW disposal at NTS supports Alternative 1 and the option for CH LLW disposal at a new on-site disposal facility supports Alternative 2. The two options, when compared, as alternatives are similar in that each can achieve the disposal objectives for the CH LLW. Also, the waste is expected to meet the requirements of the WAC at each of the disposal facilities with possibly a deviation required for the off-site disposal option. Both alternatives provide long-term environmental protectiveness and are compliant with DOT requirements or will follow a transport plan. 
The differences are:

- Alternative 1 - Off-Site Disposal of CH LLW. This alternative incurs more worker and public risk than Alternative 2 due to most travel miles, travel over public highways. This option will require more administrative and scheduling. This option is technically more complex due to the DOT requirements.

- Alternative 2 - On-Site Disposal of RH LLW. This option has the least amount of public risk due to fewest travel miles, fewest number of moves and lifts, and no travel over public highways. This option has the least amount of worker risk because of the fewest travel miles. 
Table B-3-4. Contact-handled low-level waste disposal alternatives.

\begin{tabular}{|c|c|c|}
\hline & Alternative 1-Disposal at NTS & Alternative 2-New On-Site Disposal \\
\hline \multirow{6}{*}{ 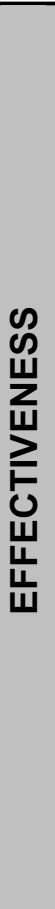 } & \multicolumn{2}{|l|}{ EFFECTIVENESS STATEMENT } \\
\hline & $\begin{array}{l}\text { Can achieve the objectives for transportation and disposal. } \\
\text { Alternative } 1 \text { results in: } \\
\text { - More miles traveled than Alternative } 2 \\
\text { - Includes travel on DOE roads and public highways } \\
\text { - More worker/public exposure than Alternative } 2 \\
\text { - More technical/administrative issues than Alternative } 2 \text {. }\end{array}$ & $\begin{array}{l}\text { Can achieve the objectives for transportation and disposal. } \\
\text { Alternative } 2 \text { results in: } \\
\text { - Fewest travel miles } \\
\text { - No travel over public highways } \\
\text { - Lowest worker/public exposure } \\
\text { - Minimal technical/administrative issues. }\end{array}$ \\
\hline & \multicolumn{2}{|l|}{ Protectiveness } \\
\hline & $\begin{array}{l}\text { Less protective during transportation and disposal than } \\
\text { Alternative } 2 \text { because: } \\
\text { - Greater transport distance is required } \\
\text { - Transport on DOE roadways and public highways } \\
\text { - Exposure to workers and public is potentially greater } \\
\text { because the waste is transported from the INL using road } \\
\text { systems with potential public exposures along the entire } \\
\text { travel route } \\
\text { - Increased mileage increases the risk of potential } \\
\text { accidents. } \\
\text { Environmental risk at each disposal site will be similar since } \\
\text { each facility is approved under DOE O } 435.1 \text {. }\end{array}$ & $\begin{array}{l}\text { More protective during transportation and disposal than Alternative } 1 \\
\text { because: } \\
\text { - Least amount of miles traveled reduces transportation risks } \\
\text { - Due to limited travel miles, least potential environmental risk } \\
\text { - Least exposure potential to the public as the waste does not leave the } \\
\text { INL site } \\
\text { - Exposure to workers is less because the waste does not leave the } \\
\text { INL site, has limited travel distance. } \\
\text { Environmental risk at each disposal site will be similar since each } \\
\text { facility is approved under DOE O } 435.1 \text {. }\end{array}$ \\
\hline & \multicolumn{2}{|l|}{ Ability to Achieve Transportation and Disposal Objectives } \\
\hline & $\begin{array}{l}\text { Alternatives } 1 \text { and } 2 \text { are capable of meeting transportation } \\
\text { and disposal objectives. }\end{array}$ & $\begin{array}{l}\text { Alternatives } 1 \text { and } 2 \text { are capable of meeting the transportation and } \\
\text { disposal objectives. }\end{array}$ \\
\hline
\end{tabular}


Table B-3-4. (continued).

\begin{tabular}{|c|c|c|}
\hline & Alternative 1-Disposal at NTS & Alternative 2-New On-Site Disposal \\
\hline \multirow{10}{*}{ 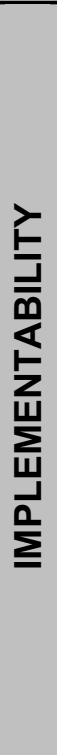 } & \multicolumn{2}{|l|}{ Technical Feasibility } \\
\hline & Technically feasible, but so is Alternative 2 . & Technically feasible, but so is Alternative 1. \\
\hline & \multicolumn{2}{|l|}{ Availability of Equipment } \\
\hline & All transport systems available through subcontracts. & All transport systems available on-site. \\
\hline & \multicolumn{2}{|l|}{ Personnel Services } \\
\hline & $\begin{array}{l}\text { For Alternative 1, subcontract personnel and facility } \\
\text { personnel with demonstrated performance will conduct the } \\
\text { transportation Disposal facility personnel will perform } \\
\text { disposal. }\end{array}$ & $\begin{array}{l}\text { For Alternative 2, facility personnel with demonstrated performance will } \\
\text { conduct transportation and disposal. }\end{array}$ \\
\hline & \multicolumn{2}{|l|}{ Disposal Facilities } \\
\hline & $\begin{array}{l}\text { Alternative } 1 \text { is more complicated to implement for } \\
\text { transportation and disposal action than Alternative } 2 \\
\text { because: } \\
\text { - Off-site transportation is required complicating the } \\
\text { planning, approvals and scheduling } \\
\text { - Transportation includes dedicated transport system } \\
\text { (commercially leases) } \\
\text { - Longer schedule required to complete disposal action. }\end{array}$ & $\begin{array}{l}\text { Alternative } 1 \text { is more complicated to implement for transportation and } \\
\text { disposal action than Alternative } 2 \text { because: } \\
\text { - Off-site transportation is required complicating the planning, } \\
\text { approvals and scheduling } \\
\text { - Transportation includes dedicated transport system (commercially } \\
\text { leases) } \\
\text { - Longer schedule required to complete disposal action. }\end{array}$ \\
\hline & \multicolumn{2}{|l|}{ Administrative Feasibility } \\
\hline & Alternative 1 is expected to meet disposal facility WAC. & Alternative 1 is expected to meet disposal facility WAC. \\
\hline
\end{tabular}




\section{B-4. REFERENCES}

10 CFR 61, 2002, Title 10, "Energy," Part 61, "Licensing Requirements for Land Disposal of Radioactive Waste," Code of Federal Regulations, Office of the Federal Register.

49 CFR 173, 2002, Title 49, "Transportation," Part 173, "Shippers-General Requirements for Shipments and Packagings," Code of Federal Regulations, Office of the Federal Register.

DOE-ID, 2001, Idaho National Engineering and Environmental Laboratory Reusable Property, Recyclable Materials, and Waste Acceptance Criteria (RRWAC), DOE/ID-10381, Rev. 12, U.S. Department of Energy Idaho Operations Office, Idaho Falls, Idaho.

DOE-ID, 2005, Idaho CERCLA Disposal Facility Complex Waste Acceptance Criteria, DOE/ID-10881, Rev. 2, U.S. Department of Energy Idaho Operations Office, Idaho Falls, Idaho.

DOE-NV, 2006, Nevada Test Site Waste Acceptance Criteria, DOE/NV-325, Rev. 6, U.S. Department of Energy Nevada, October 2003.

DOE O 435.1, 2001, “Radioactive Waste Management,” U.S. Department of Energy, August 28, 2001.

Hanford Site Solid WAC, HNF-EP-0063, Rev. 13

Janke, D. H., 2000, U.S. Department of Energy - Idaho Operations Office, Idaho National Engineering and Environmental Laboratory Interim Pollution Prevention Plan, DOE/ID-10333(00), U.S. Department of Energy Idaho Operations Office, Idaho Falls, Idaho.

Weapons Complex Monitor, 2006, Washington D.C., June 6, 2006. 


\section{Appendix C \\ Regulatory Evaluation}




$$
\text { C-2 }
$$




\section{Appendix C}

\section{Regulatory Evaluation}

This appendix presents and evaluates the regulatory framework for low-level waste (LLW) disposal. Requirements that apply to commercial and U.S. Department of Energy (DOE) facilities are examined. The key areas of regulatory focus are the licensing of commercial facilities, DOE regulation of its disposal facilities, and compliance with the National Environmental Policy Act (NEPA).

\section{C-1. REGULATORY REQUIREMENTS FOR COMMERCIAL DISPOSAL OF IDAHO NATIONAL LABORATORY LOW-LEVEL WASTE}

Under the Atomic Energy Act of 1954 (Public Law 83-703), as amended, regulation of non-DOE managed radioactive materials is the responsibility of the Nuclear Regulatory Commission (NRC). The NRC can agree to delegate its authority to a state that can demonstrate that it has qualified regulatory program in place. For Idaho National Laboratory's (INL's) interests, both Utah and Washington are NRC Agreement States and administer the LLW disposal program; Idaho has not been delegated authority.

The Low-Level Radioactive Waste Policy Amendments Act of 1985 (LLRWPAA) (Public Law 99-240) includes incentives and milestones for states to establish disposal capacity for wastes generated within their borders. This statute specified that DOE is responsible for LLW generated by its facilities, from Navy decommissioned nuclear power ships, from the government's research and development related to atomic weapons, and for wastes with concentrations that exceed the limits established for Class $\mathrm{C}$ radioactive waste. States are responsible for other waste generated by the federal government. This Act encourages development of regional compacts among states for development of disposal capacity. DOE Order 435.1 governs DOE waste management and provides that DOE waste may be disposed in a commercial landfill with approval from the field office after notification to Department of Energy Headquarters (DOE-HQ) and consultation with the Department of Energy Environment, Safety, and Health (DOE-EH). However, compact or commercial facilities are not obligated to accept DOE waste.

The Northwest Compact, formed pursuant to the LLRWPAA in December 1985, includes the member states of Washington, Alaska, Hawaii, Idaho, Montana, Oregon, Utah, and Wyoming. The first regional disposal facility was located on the Hanford Site and is currently operated by U.S. Ecology. In 1988, the Energy Solutions facility in Clive, Utah was opened but limited to disposal of low-activity, naturally-occurring radioactively-contaminated wastes. In 1995, the Northwest Compact agreed that the facility could take large-volume soil, soil-like materials, and debris, including waste generated from operations and routine cleanups.

The requirements for siting and operation of commercial disposal facilities are established by NRC. 10 CFR 61 contains the provisions for regulation of commercial LLW from generation through disposal, including closure of disposal facilities. The regulations include performance objectives and technical requirements for waste classification, site suitability, facility design, operations, closure, and monitoring. 10 CFR 51 provides the regulations for NRC's compliance with NEPA for LLW facilities. The NEPA evaluation is conducted in conjunction with the licensing activity.

Neither DOE Order 435.1 nor 10 CFR 61 requires artificial or clay liners for LLW land disposal. These RCRA-type liners are traditionally not used for LLW disposal facilities because, since the development of 10 CFR 61, the concept of "controlled release" has been understood to be an effective 
approach for managing LLW disposal. In reference to 10 CFR 61.51, Disposal Site Design, item (6), the Final EIS on 10 CFR 61, NUREG-0945, Vol. 1, p. 5-14, states that allowing for some leakage is actually desirable:

\begin{abstract}
"Reducing the contact time of water with the waste by using freelydraining granular backfill should be considered. In addition, the accumulation of water in the disposal unit (the bathtub effect) must be avoided. This can normally be accomplished if the bottom of the disposal unit can drain at least as readily as water can infiltrate into the disposal unit through the cover or sides...."
\end{abstract}

Relying on an artificial or clay liner also contradicts a technical requirement in 10 CFR 61 to not become dependent on a design feature that could require long-term maintenance. Specifically, in the original Federal Register notification for 10 CFR 61 (47 FR 57450), the first paragraph states:

"The Commission takes exception to any design which relies on a leachate collection and treatment system to reduce migration. Such a design is expected to result in a requirement for continued active site maintenance, therefore violating the performance objective in [10 CFR Part] 61.44."

LLW is defined under the LLWPAA and the NRC regulations as waste that is not transuranic waste, spent nuclear fuel, by-product material, or high level waste. LLW slated for commercial disposal is classified as Class A, Class B, or Class C. These classes involve increasingly stringent requirements for waste form and stability and measures to protect against inadvertent intrusion. Waste that involves higher concentrations and different and more stringent disposal methods from Class $\mathrm{C}$ is not generally acceptable for near-surface disposal unless approved by the NRC. This waste is referred to as Greater-Than-Class-C (GTCC) waste.

\title{
C-2. REGULATORY REQUIREMENTS FOR DISPOSAL OF LOW-LEVEL WASTE AT A DEPARTMENT OF ENERGY FACILITY
}

DOE Order 435.1 governs LLW management at DOE facilities. Order 435.1 includes the following performance objectives for a LLW disposal facility:

- Dose to representative members of the public shall not exceed $25 \mathrm{mrem}(0.25 \mathrm{mSv})$ in a year total effective dose equivalent from all exposure pathways, excluding the dose from radon and its progeny in air.

- Dose to representative members of the public via the air pathway shall not exceed $10 \mathrm{mrem}$ $(0.10 \mathrm{mSv})$ in a year total effective dose equivalent, excluding the dose from radon and its progeny.

- Release of radon shall be less than an average flux of $20 \mathrm{pCi} / \mathrm{m}^{2} / \mathrm{s}\left(0.74 \mathrm{~Bq} / \mathrm{m}^{2} / \mathrm{s}\right)$ at the surface of the disposal facility. Alternatively, a limit of $0.5 \mathrm{pCi} / 1(0.0185 \mathrm{~Bq} / 1)$ of air may be applied at the boundary of the facility.

Each disposal facility conducts a performance assessment that includes calculations for a 1,000-year period after closure of potential doses to representative future members of the public and potential releases from the facility. The performance assessment is then used to establish the limits on the concentrations of radionuclides that can be disposed. 
A Disposal Authorization Statement must be obtained from DOE-HQ before construction of a new disposal facility. This statement is based upon a review of the facility's design and documentation. It provides the specific limits for design, construction, operation, and closure.

DOE uses a definition of LLW similar to NRC: "Low-level radioactive waste is radioactive waste that is not high-level radioactive waste, spent nuclear fuel, transuranic waste, byproduct material (as defined in Section 11e.(2) of the Atomic Energy Act of 1954, as amended), or naturally occurring radioactive material." However, DOE's system does not provide further waste classifications.

Decisions regarding disposal at facilities regulated by DOE are subject to NEPA evaluation. DOE has codified its NEPA compliance rules in 10 CFR 1021. Previous DOE NEPA reviews and decisions for actions proposed for LLW waste management can be used to support the NEPA process for INL LLW disposal plans after Fiscal Year (FY) 2009.

The impacts of disposal of LLW off-site and on-site at the INL have been evaluated in two Environmental Impact Statements (EISs), (1) Programmatic Spent Nuclear Fuel and Idaho National Engineering Laboratory Environmental Restoration and Waste Management EIS (DOE 1995) and (2) the Waste Management Programmatic EIS (DOE 1997). These EISs address LLW in general without distinguishing between remote handled and contact handled LLW. The volume and characteristics of the INL LLW in these EISs were based upon conservative estimates that exceed current LLW volume projections and inventories. NEPA analysis for the decision on disposal of INL's LLW will tier from the decisions made in these EISs by referencing the affected environment and the impacts analysis for off-site and on-site disposal. On-site disposal of LLW was selected in the Record of Decision (ROD) for the Programmatic Spent Nuclear Fuel and Idaho National Engineering Laboratory Environmental Restoration Waste Management EIS (60 FR 28680). The decision for LLW in the Waste Management Programmatic EIS expanded INL options. That ROD identifies Hanford and Nevada Test Site (NTS) as regional disposal sites, with on-site disposal taking place at INL, Savannah River Site, Oak Ridge National Laboratory, and Los Alamos National Laboratory (65 FR 10061).

No new decisions are posed by the approach recommended for INL LLW disposition beyond selection of the type and location of a new on-site disposal facility. An Environmental Assessment (EA) is recommended to address the specific impacts posed by construction, operation, and end-state of a new disposal facility. The EA would document the NEPA analysis and decisions from the EISs and assess the significance of the impacts for the alternatives under consideration.

Continued use of existing facilities for the same purpose and types of waste during the interim, as authorized by the previous RODs and as reviewed in Supplemental Analyses, would not be subject to further NEPA review.

Waste that has no path to disposal and characteristics similar to waste classified as GTCC under the NRC definitions is not addressed in the two EISs above. Under the Low-Level Radioactive Waste Policy Amendments Act of 1985, the federal government is responsible for the disposal of greater-than-Class-C low-level waste generated by licensees of the NRC and Agreement States. DOE was identified as the federal agency responsible for this effort. In February 1989, a report to Congress from DOE (1990) stated that it plans to accept and manage limited quantities of greater-than-Class-C low-level waste until a disposal facility is developed.

DOE has issued an Advance Notice of Intent to prepare an EIS specifically to address disposal of GTCC LLW generated from facilities licensed by the NRC and waste with similar characteristics (70 FR 24775). Decisions on future management of this waste will be made pursuant to this EIS. However, at this time, it is not known whether the scope of the EIS will extend to DOE's similar waste. 


\section{C-3. REFERENCES}

10 CFR 51, 2002, Title 10, "Energy," Part 51, "Environmental Protection Regulations for Domestic Licensing and Related Regulatory Functions," Code of Federal Regulations, Office of the Federal Register.

10 CFR 61, 2002, Title 10, "Energy,” Part 61, "Licensing Requirements for Land Disposal of Radioactive Waste," Code of Federal Regulations, Office of the Federal Register.

10 CFR 1021, 2002, Title 10, "Energy,” Part 1021, "National Environmental Policy Act Implementing Procedures," Code of Federal Regulations, Office of the Federal Register.

60 FR 28680, 1995, "Record of Decision: Programmatic Spent Nuclear Fuel Management and Idaho National Engineering Laboratory Environmental Restoration and Waste Management Programs,” Federal Register, U.S. Environmental Protection Agency, June 1, 1995.

65 FR 10061, 2000, "Record of Decision for the Department of Energy's Waste Management Program: Treatment and Disposal of Low-Level Waste and Mixed Low-Level Waste; Amendment to the Record of Decision for the Nevada Test Site," Federal Register, U.S. Environmental Protection Agency, February 25, 2000.

70 FR 24775, 2005, “Advance Notice of Intent To Prepare an Environmental Impact Statement for the Disposal of Greater-Than-Class-C Low-Level Radioactive," Federal Register, U.S. Environmental Protection Agency, May 11, 2005.

DOE, 1990, “1989 Annual Report on Low-Level Radioactive Waste Management Progress,” DOE/EM0006P, Washington, DC: DOE Office of Environmental Restoration and Waste Management, U.S. Department of Energy, October 1990.

DOE, 1995, Programmatic Spent Nuclear Fuel Management and Idaho National Engineering Laboratory Environmental Restoration and Waste Management Programs Final Environmental Impact Statement, DOE/EIS-203-F, U.S. Department of Energy, Office of Environmental Management, August 1995.

DOE, 1997, Final Waste Management Programmatic Environmental Impact Statement for Managing Treatment, Storage, and Disposal of Radioactive and Hazardous Waste, DOE/EIS-200-F, U.S. Department of Energy, Office of Environmental Management, June 1997.

DOE O 435.1, 2001, "Radioactive Waste Management,” U.S. Department of Energy, August 28, 2001.

PL 83-703, 1954, "The Atomic Energy Act of 1954, as amended," 42 U.S.C. 201, (August 30, 1954) [established requirements for availability and dissemination of information generated by or for DOE], Public Law.

PL 99-240, 1986, “Low-Level Radioactive Waste Policy Act,” Public Law, January 15, 1986. 


\title{
Appendix D \\ Low-Level Waste Disposal Alternative Scenarios Assumptions, Schedules, Costs
}

\author{
Contents \\ Appendix D-1-Scenario 1: Disposal of All Low-Level Waste On-Site \\ Appendix D-2 - Scenario 2: Disposal of all Low-Level Waste Off-Site at Nevada Test Site \\ Appendix D-3 - Scenario 3: Disposal of Contact-Handled Low-Level Waste, Remote-Handled Debris, \\ and Remote-Handled Resins at Nevada Test Site; Disposal of Remote-Handled Activated \\ Metals at Hanford \\ Appendix D-4-Scenario 4: Shipment of Contact-Handled Low-Level Waste, Remote-Handled Resins, \\ and Remote-Handled Debris to Nevada Test Site; Disposal of Remote-Handled Activated \\ Metals On-Site
}


D-2 


\section{Appendix D}

\section{Disposal of All Low-Level Waste On-Site}

This Appendix provides cost and schedule information for the LLW disposal scenarios. For each scenario, the following information is presented:

- A summary of total costs including the basis of estimate

- Annual total, operating, and capital costs for the scenario

- A schedule. 
D-4 


\section{Appendix D-1 \\ Scenario 1: \\ On-Site Disposal of Contact-Handled and Remote-Handled Low-Level Waste}

\begin{tabular}{lr}
\multicolumn{1}{c}{ Activities } & Cost \\
\hline 1. Approve Mission Need/Cost Range & $\$ 2,882,384$ \\
2. Critical Decision (CD)-2/CD-3 Approve Mission Performance Baseline/ & $\$ 40,254,365$ \\
and Execute Design-Build & $\$ 4,746,501$ \\
5. CD-4 Approve Start of Operations & $\$ 216,953,968$ \\
6. Off Site LLW Shipments (Interim) & $\$ 5,956,752$ \\
\hline & $\$ 35,806,876$ \\
\hline
\end{tabular}

\section{D-1.1. Basis of Estimate}

Costs for this scenario are based upon:

1. "Combined RH-LLW \& CH-LLW On-Site Disposal Unlined Landfill," Cost Estimate \#9A04, R.R. Honsinger (8-10-06)

2. Operational and vault design costs taken from the SDA

3. Adjusted landfill costs from ICDF design and construction

4. Facility closure estimates adjusted from EDF-2385 INEEL CERCLA Disposal Facility On-Site versus Off-Site Cost Comparison.

\section{D.1.2. Contingency Analysis}

Each cost estimate prepared to support this scenario applied a contingency. The average contingency for the scenario is $30 \%$. Contingency addresses the following uncertainties:

1. This a pre-conceptual design estimate

2. The relative remote nature of the facility

3. The actual facility site has not been selected 
4. Materials, charging practices, rates, and labor costs cannot be projected accurately over the 28-year time span

5. Regulatory and political uncertainty

6. The costing system that provided historical costs does not differentiate costs to a level of detail necessary to ensure all costs were captured

7. Any mathematical differences are a result of rounding numbers between programs.

\section{D.1.3. Specific Assumptions}

1. Post closure monitoring and surveillance costs are assumed to be absorbed into overall site long-term stewardship costs for the INL assumed by the Office of Legacy Management. The above-referenced EDF assumed less than one FTE in overall costs for twice annual sampling and drive-by surveillance.

2. The estimate is based upon construction of a disposal cell in line with current industry engineering design practices for LLW disposal. 


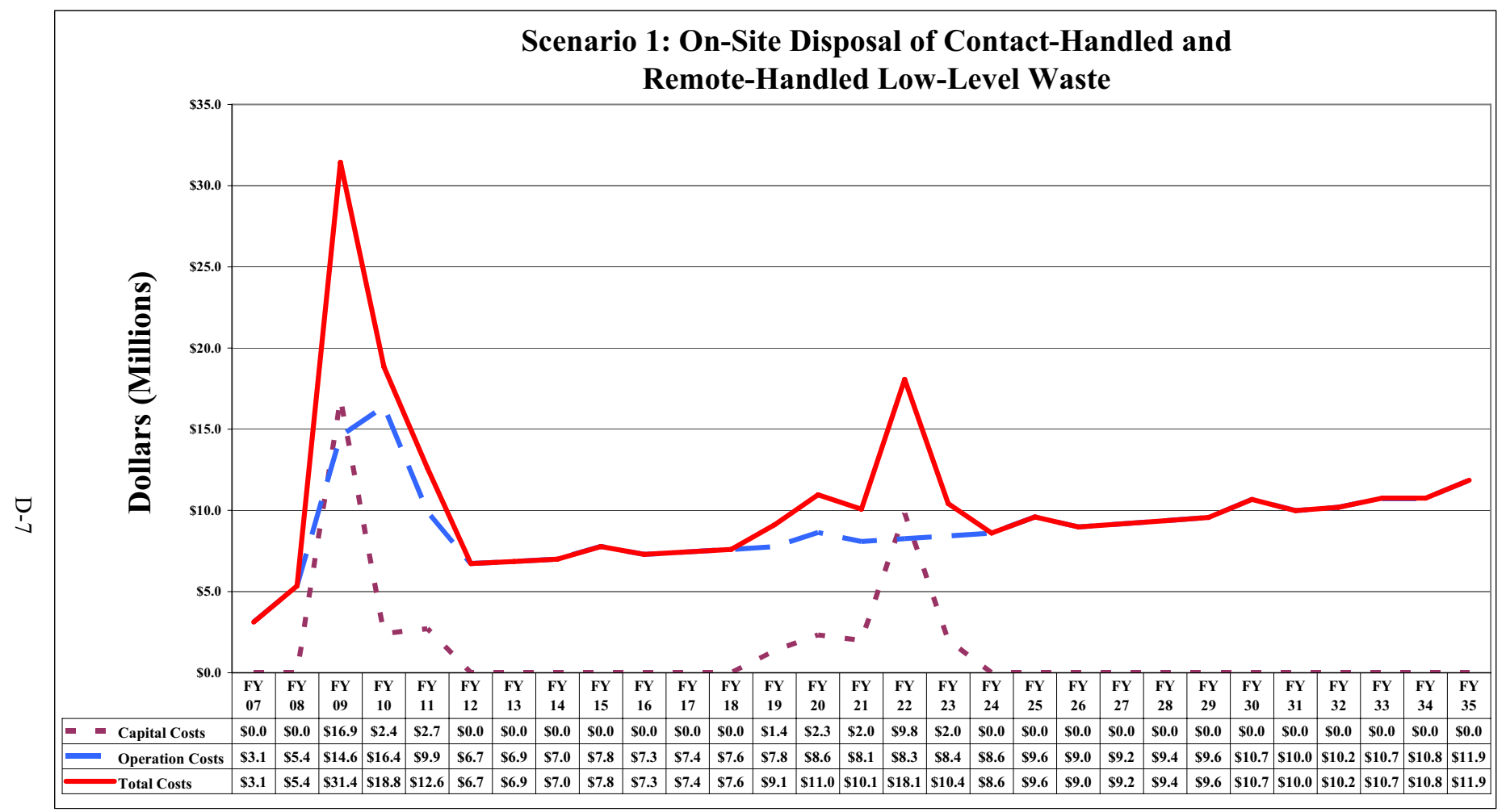




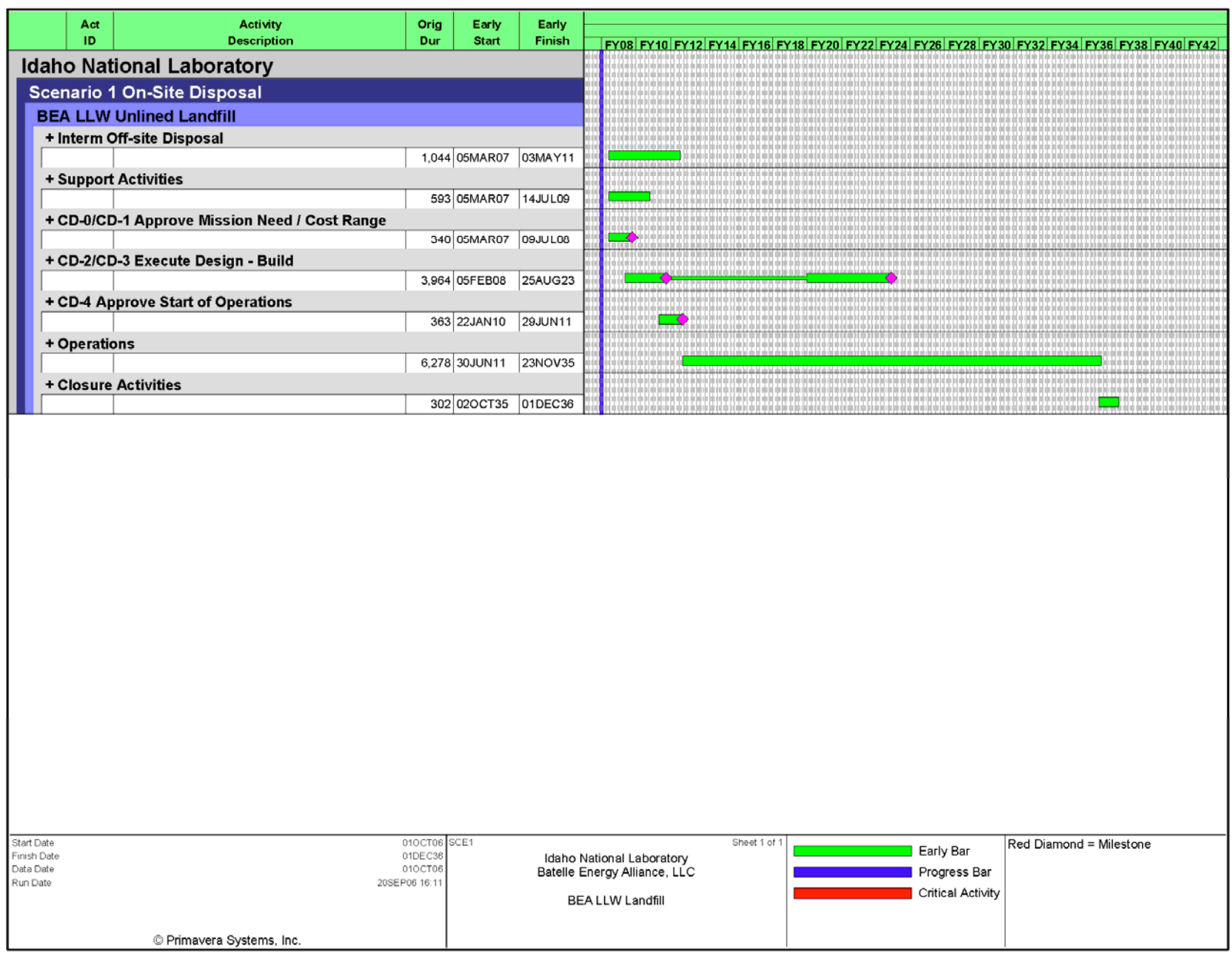




\section{Appendix D-2}

Scenario 2:

Disposal of all Low-Level Waste Off-Site at Nevada Test Site

\begin{tabular}{|c|c|}
\hline Activities & Cost \\
\hline 1. Cask Procurement and Infrastructure Development & $\$ 41,407,521$ \\
\hline 2. Activated Metals to NTS (Ops) & $\$ 371,225,189$ \\
\hline 3. Off-Site Disposal of Debris & $\$ 12,847,202$ \\
\hline 4. Off-Site Disposal of Resins & $\$ 68,910,270$ \\
\hline 5. CH LLW Off Site Disposal & $\$ 322,217,797$ \\
\hline & $\$ 816,607,979$ \\
\hline
\end{tabular}

\section{D-2.1 Basis of Estimate}

Costs for this scenario are based upon:

1. "Off-Site Disposal Detailed Work Package spreadsheet" (C.K. Mullen, 7/2/2003) and "Off-Site Transportation and Disposal spreadsheet" (R.R. Seitz, 9/8/2003) - along with discussions with R. Grant

2. “CH LLW Off-Site Disposal (FY 2009-FY 2035)," Cost Estimate \#9A02, R.R. Honsinger (7-3-06)

3. "RH LLW -- Packaging, Transportation and Disposal of $6 \mathrm{~m}^{3}$ Type A Shielded Containers at NTS," Cost Estimate \#M-406-K, D.A. Rowley (4-18-06)

4. "RH LLW - ATR Resins - Shielded Type A Containers Shipped to NTS," Cost Estimate \#M-406-J, Revision 1, D.A. Rowley, R.R. Honsinger (7-13-06)

5. "RH LLW - Infrastructure Costs at NTS," Cost t Estimate \#M-406-A, D.A. Rowley (4-10-06)

6. "RH LLW - Truck Transported - Development, Testing, and Approval," Cost Estimate \#M-406-E, Revision 1, R.D. Roseland, R.R. Honsinger (8-22-06)

7. "RH LLW - Truck Transported - Packaging, Transportation, and Disposal," Cost Estimate \#M-406-C, Revision 1, D.A. Rowley, R.R. Honsinger (7-12-06) 
8. NRF memo identifying NRF infrastructure changes and costs to support off-site LLW disposal (1-09-06); NRF Infrastructure Cost Worksheet (8-17-06).

\section{D-2.2 Contingency Analysis}

Each cost estimate prepared to support this scenario applied a contingency. The average contingency for the scenario is $30 \%$. Contingency addresses the following uncertainties:

1. Materials, charging practices, rates, and labor costs cannot be projected accurately over the 28-year time span

2. Regulatory and political uncertainty

3. The costing system that provided historical costs does not differentiate costs to a level of detail necessary to ensure all costs were captured

4. Some activities may have been missed, which could result in significant cost impacts when escalated over the life of the project (through FY 2035).

\section{D-2.3 Specific Assumptions}

1. NTS will continue to be a viable disposal path throughout the duration of this project.

2. Capital funding will be available in FY 2009. 


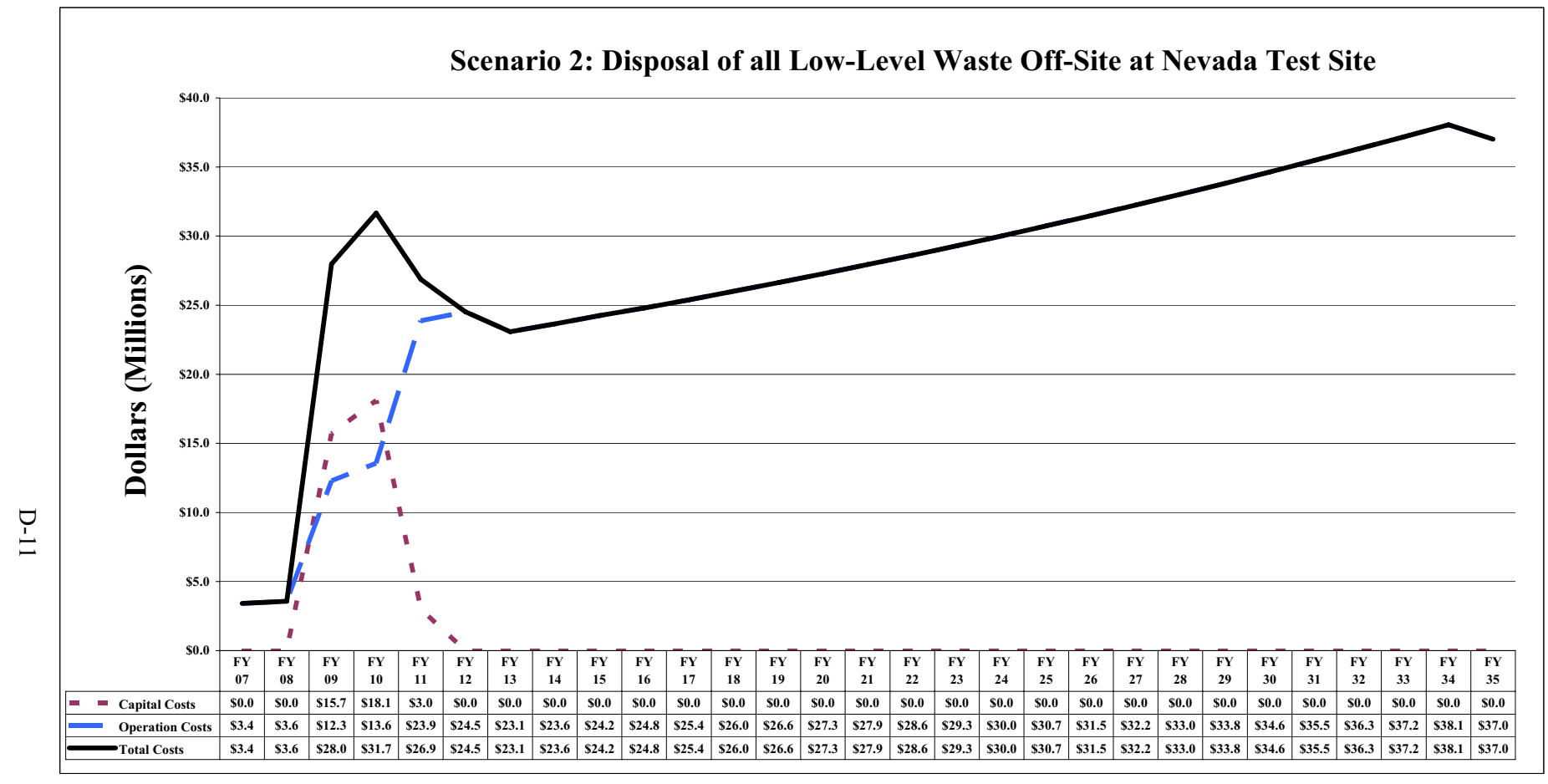




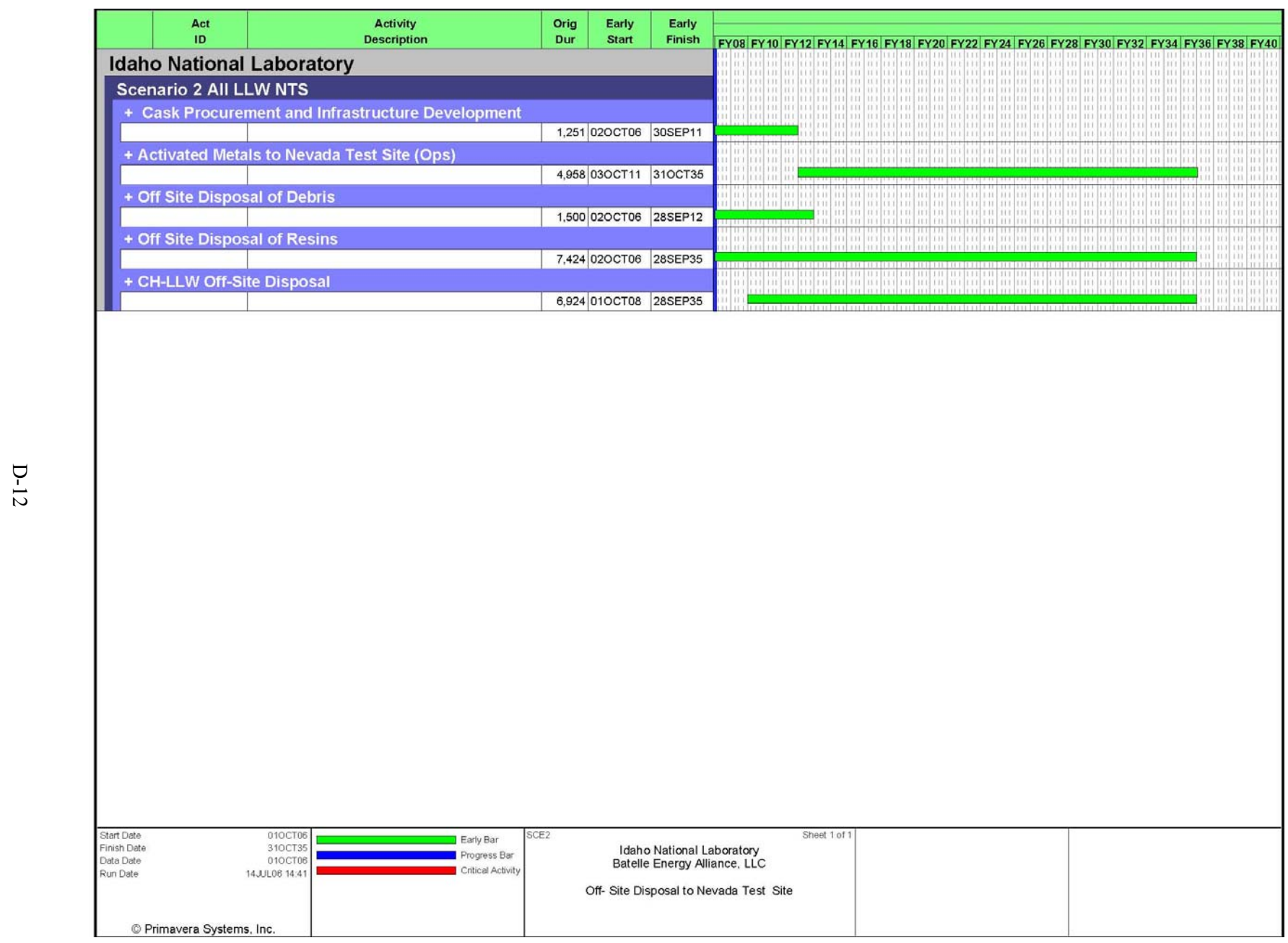




\section{Appendix D-3}

\section{Scenario 3:}

Disposal of Contact-Handled Low-Level Waste, Remote-Handled Debris, and Remote-Handled Resins at Nevada Test Site; Disposal of Remote-Handled Activated Metals at Hanford

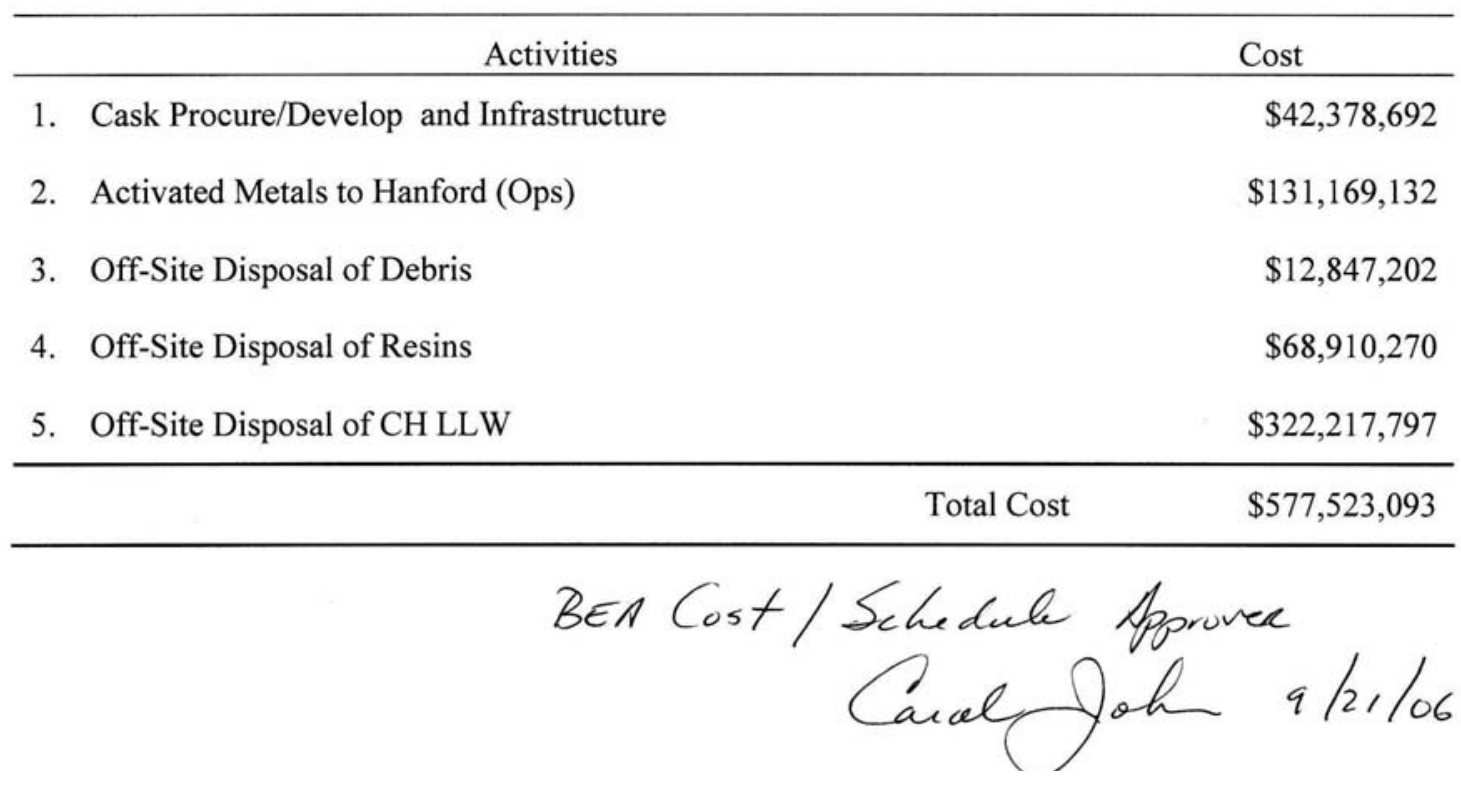

\section{D-3.1 Basis of Estimate}

Costs for this scenario are based upon:

1. "Off-Site Disposal Detailed Work Package spreadsheet" (C.K. Mullen, 7/2/2003) and "Off-Site Transportation and Disposal spreadsheet" (R.R. Seitz, 9/8/2003) - along with discussions with R. Grant

2. “CH LLW Off-Site Disposal (FY 2009-FY 2035)," Cost Estimate \#9A02, R.R. Honsinger (7-3-06)

3. "RH LLW - Packaging, Transportation and Disposal of $6 \mathrm{~m}^{3}$ Type A Shielded Containers at NTS," Cost Estimate \#M-406-K, D.A. Rowley (4-18-06)

4. "RH LLW - ATR Resins - Shielded Type A Containers Shipped to NTS," Cost Estimate \#M-406-J, Revision 1, D.A. Rowley, R.R. Honsinger (7-13-06)

5. "RH LLW - Infrastructure Costs at Hanford," Cost Estimate \# M-406-B, D.A. Rowley (4-10-06) 
6. "RH LLW - Rail Transported - Development, Testing, and Approval," Cost Estimate \#M-406-F, Revision 1, R.D. Roseland, R.R. Hosinger (8-22-06)

7. "RH LLW - Rail Transported - Additional Rail Transported Shipping Cask System," Cost Estimate \#M-406-H, R.D. Roseland (1-26-06)

8. "RH LLW - Rail Transported - Packaging, Transportation, and Disposal," Cost Estimate \#M-406-D, R.D. Roseland (1-26-06)

9. “RH LLW Truck Transported - Development, Testing and Approval," Cost Estimate \#M-406-E, Revision 1, R.D. Roseland, R.R. Hosinger (8-9-06)

10. "RH LLW - Truck Transported - Packaging, Transportation and Disposal," Cost Estimate \#M-406-C, Revision 1, D.A. Rowley, R.R. Hosinger (7-12-06)

11. NRF memo identifying NRF infrastructure changes and costs to support off-site LLW disposal (1-09-06); NRF Infrastructure Cost Worksheet (8-17-06).

\section{D-3.2 Contingency Analysis}

Each cost estimate prepared to support this scenario applied a contingency. The average contingency for the scenario is $30 \%$. Contingency addresses the following uncertainties:

1. Materials, charging practices, rates, and labor costs cannot be projected accurately over the 28-year time span

2. Regulatory and political uncertainty

3. The costing system that provided historical costs does not differentiate costs to a level of detail necessary to ensure all costs were captured

4. Some activities may have been missed, which could result in significant cost impacts when escalated over the life of the project (through FY 2035).

\section{D-3.3 Specific Assumptions}

1. NTS will continue to be a viable disposal path throughout the duration of this project

2. Hanford will continue to be a viable disposal path throughout the duration of this project.

3. Capital funding will be available in FY 2009. 


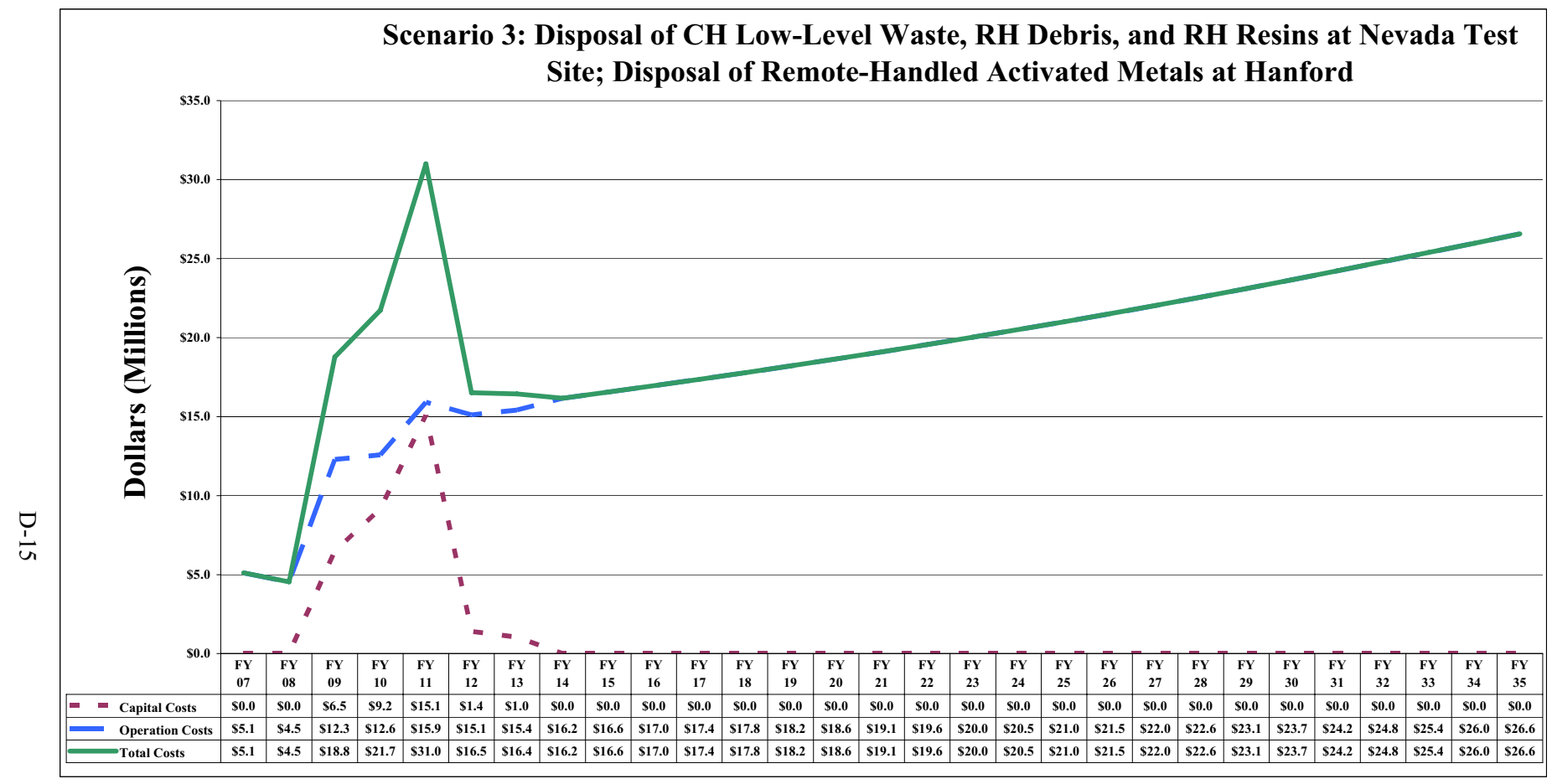




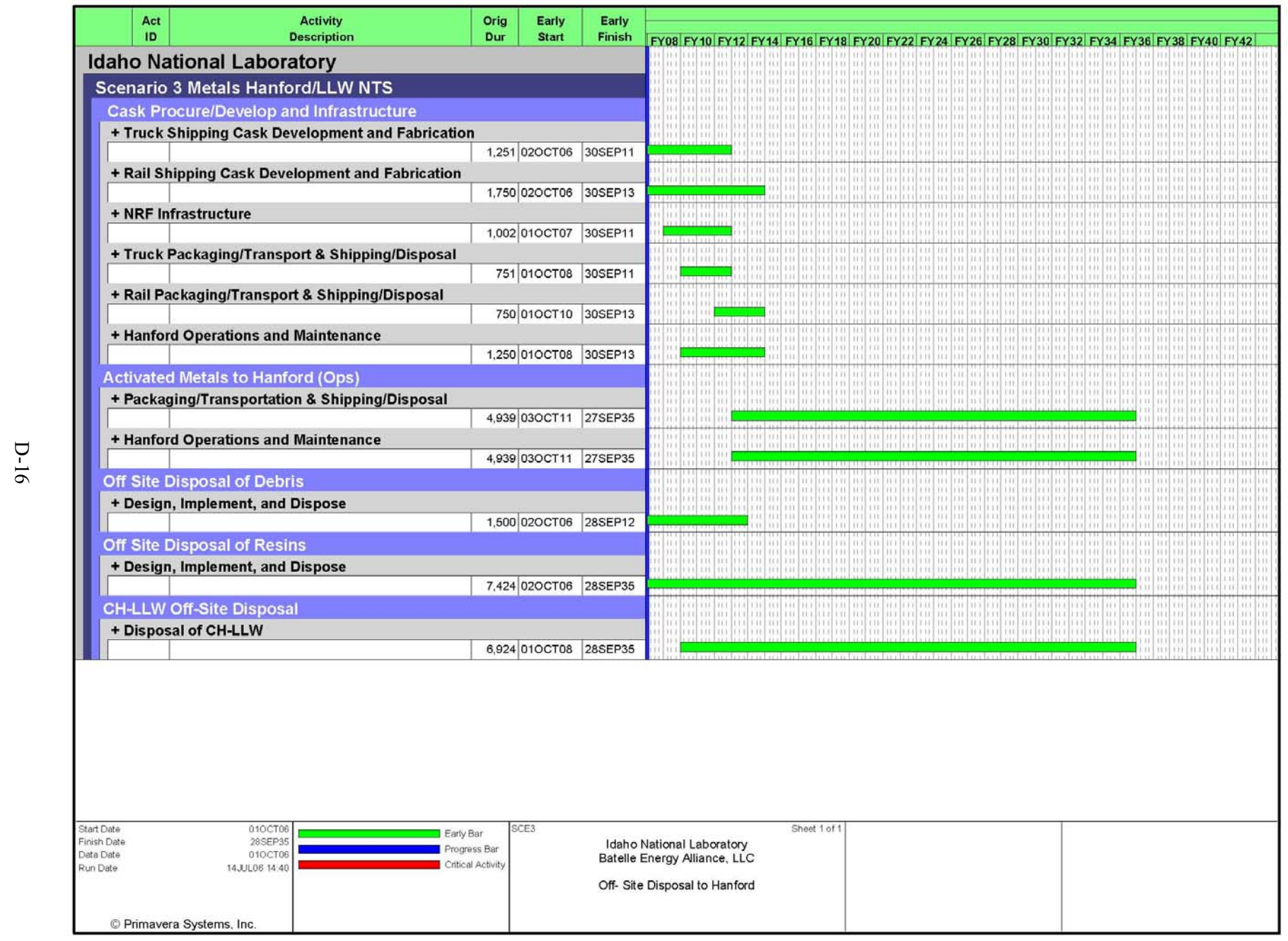




\section{Appendix D-4}

\section{Scenario 4:}

\section{Shipment of Contact-Handled Low-Level Waste, Remote-Handled}

Resins, and Remote-Handled Debris to Nevada Test Site; Disposal of Remote-Handled Activated Metals On-Site

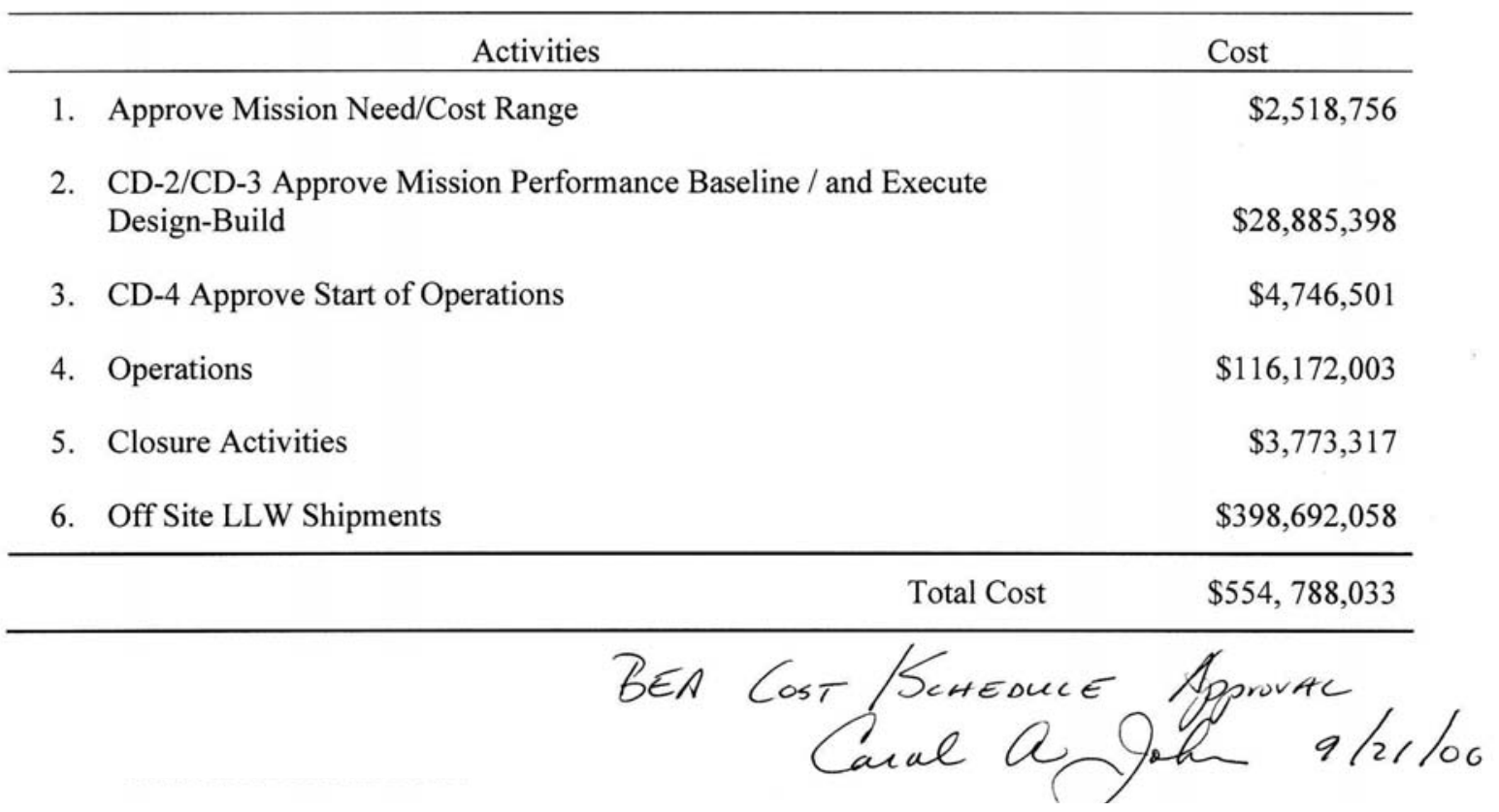

\section{D-4.1 Basis of Estimate}

Costs for this scenario are based upon:

1. "RH LLW Activated Metals On-Site Disposal" Cost Estimate \#9A07, R.R. Honsinger (7-14-06)

2. “CH LLW Off-Site Disposal (FY 2009-FY2035)," Cost Estimate \#9A02, R.R. Honsinger (7-3-06)

3. "RH LLW Packaging, Transportation and Disposal of $6 \mathrm{~m}^{3}$ Type A Shielded Containers at NTS," Cost Estimate \#M-406-K, D.A. Rowley (4-18-06)

4. "RH LLW - ATR Resins - Shielded Type A Containers Shipped to NTS," Cost Estimate \#M-406-J, Revision 1, D.A. Rowley, R.R. Honsinger (7-12-06)

5. Operational and vault design costs taken from the SDA

6. Adjusted costs from ICDF design and construction 
7. Facility closure estimates adjusted from EDF-2385 INEEL CERCLA Disposal Facility On-Site versus Off-Site Cost Comparison. 


\section{D-4.2 Contingency Analysis}

Each cost estimate prepared to support this scenario applied a contingency. The average contingency for the scenario is $30 \%$. Contingency addresses the following uncertainties:

1. Unit costs at NTS are variable to cover fixed costs dependent upon the number of facility users

2. This a pre-conceptual design estimate

3. The relatively remote nature of the facility

4. The actual disposal facility site has not been selected

5. Materials, charging practices, rates, and labor costs cannot be projected accurately over the 28-year time span

6. Regulatory and political uncertainty

7. The costing system that provided historical costs does not differentiate costs to a level of detail necessary to ensure all costs were captured

8. Any mathematical differences are a result of rounding numbers between programs.

\section{D-4-3 Specific Assumptions}

Post closure monitoring and surveillance costs for the vaults are assumed to be absorbed into overall site long-term stewardship costs for the INL assumed by the Office of Legacy Management. The above-referenced EDF assumed less than one FTE in overall costs for twice annual sampling and drive-by surveillance. 


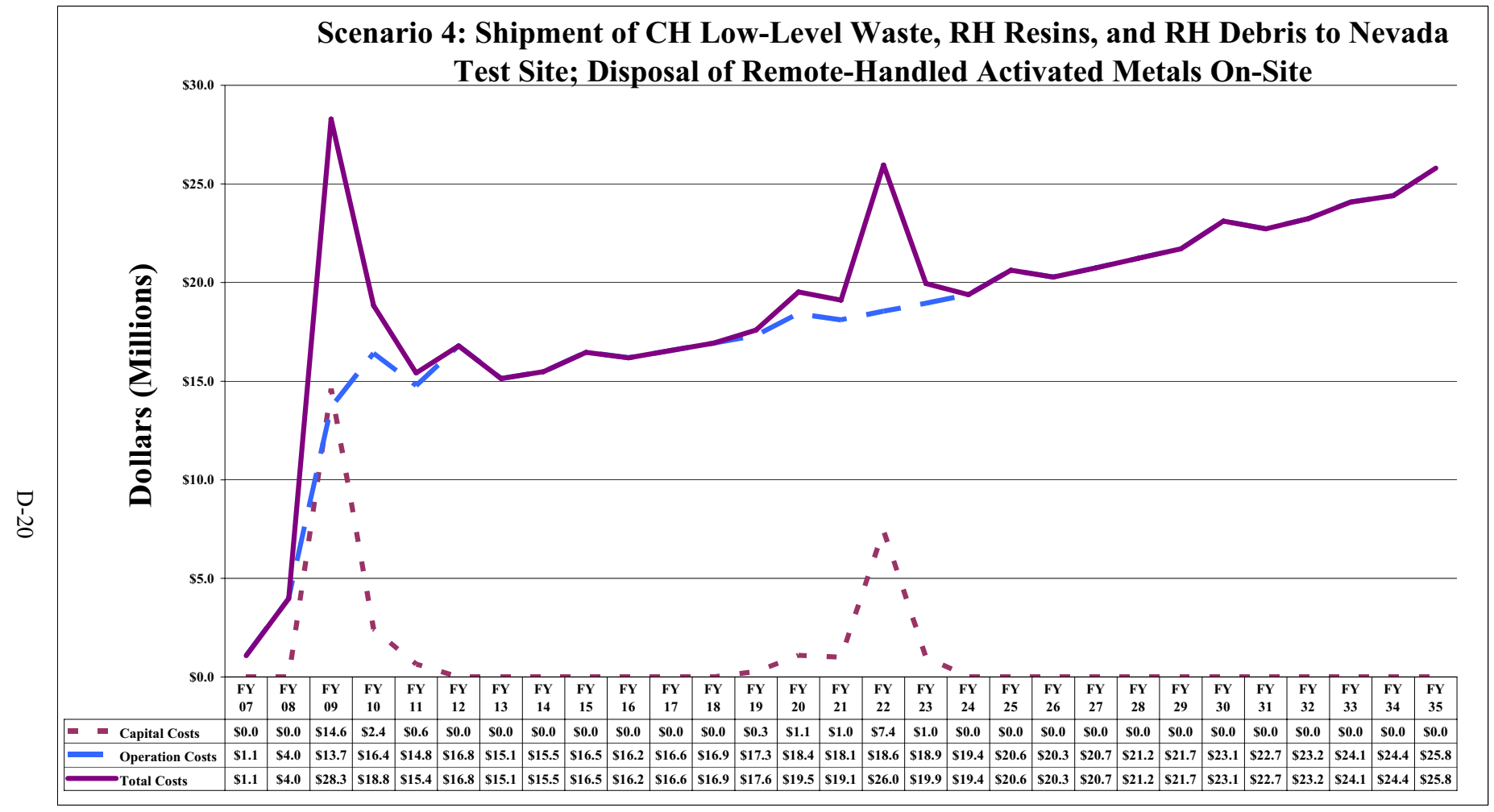




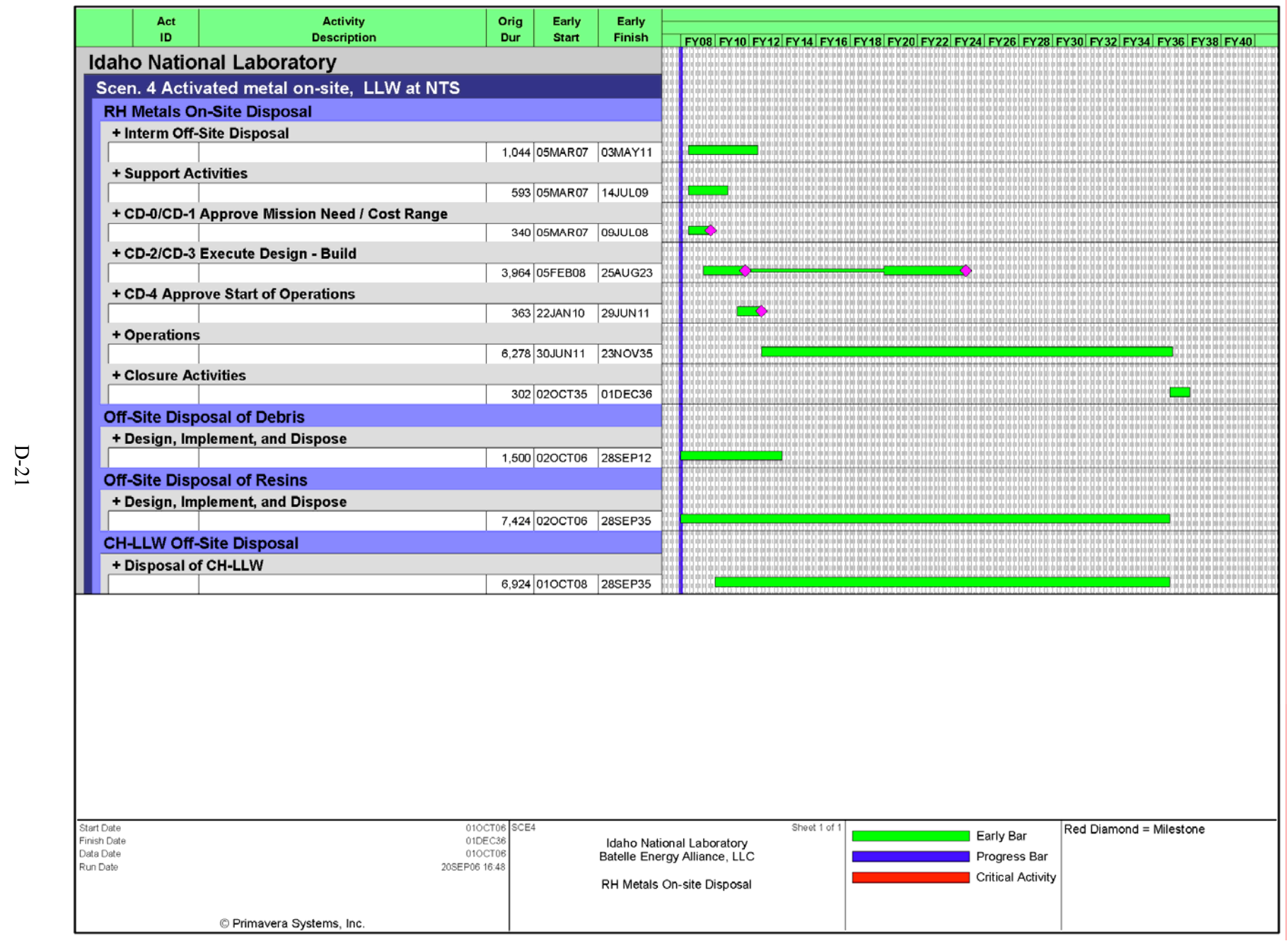




\section{Appendix E \\ Activated Metals Cask Search and Selection}


E-2 


\section{Appendix E}

\section{E-1. ACTIVATED METALS CASK SEARCH AND SELECTION}

The purpose of this activity was to locate all casks certified for use in interstate commerce that meet the operational requirements of transporting activated metals generated by the Advanced Test Reactor (ATR), the Materials and Fuels Complex (MFC) and the Naval Reactors Facility (NRF) at the Idaho National Laboratory (INL). To accomplish this task, the basic equipment interface needs of the subject facilities were determined to support a cost effective common system. A search for acceptable casks was conducted utilizing the RAMPAC database and guidelines provided in the U.S. Department of Energy (DOE) Office of Transportation bulletin "Regulatory and Legislative Development Highlights," dated June 2006.

The cask criteria for the remote-handled (RH) low-level waste (LLW) activated metals are contained in Table E-1.

Table E-1. Cask criteria.

\begin{tabular}{|c|c|c|c|c|c|}
\hline $\begin{array}{c}\text { Loaded Cask } \\
\text { Weight }^{1} \\
(\mathrm{lb})\end{array}$ & $\begin{array}{l}\text { Loading } \\
\text { Method }^{2}\end{array}$ & $\begin{array}{c}\text { Hard Gamma } \\
\text { Curie } \\
\text { Capacity }^{3} \\
\end{array}$ & $\begin{array}{c}\text { Insert } \\
\text { Dimensions }{ }^{4} \\
\end{array}$ & $\begin{array}{l}\text { Insert Weight } \\
\text { Limit }\end{array}$ & $\begin{array}{c}\text { Mode of } \\
\text { Travel }\end{array}$ \\
\hline $\begin{array}{l}\leq 80,000 \text { for } \\
\text { Truck-Loaded } \\
>80,000 \text { for } \\
\text { Rail-Loaded }\end{array}$ & Dry and Wet & $15,000 \mathrm{R} / \mathrm{h}$ & $\begin{array}{c}\geq 96 " \mathrm{~h} \\
20 " \text { diameter }\end{array}$ & Cask Driven & $\begin{array}{c}\text { Public } \\
\text { Highway or } \\
\text { Railroad }\end{array}$ \\
\hline $\begin{array}{l}\text { This limit is } \\
\text { casks were a } \\
\text { 2. Two basic lo } \\
\text { loading from } \\
\text { 3. It is assumed } \\
\text { date: } 1 \%>1 \\
15,000 \mathrm{R} / \mathrm{hr} \\
\text { 4. This insert } \mathrm{d}\end{array}$ & $\begin{array}{l}\text { Iven by the crane } \mathrm{c} \\
\text { evaluated as an of } \\
\text { ing methods will b } \\
\text { ot cell operations d } \\
\text { lat the dose rate on } \\
000 \mathrm{R} / \mathrm{hr}(30,000 \mathrm{R} \\
\text { site for decay to le } \\
\text { ension is the minin }\end{array}$ & $\begin{array}{l}\text { city at the Advanc } \\
\mathrm{n} \text { for rail transport } \\
\text { ed: bottom loadir } \\
\mathrm{n} \text { into the cask. } \\
\text { tact for the entire } \\
\text { maximum); } 9 \%> \\
\text { han } 15,000 \mathrm{R} / \mathrm{hr} \text {. } \\
\text { size acceptable f }\end{array}$ & $\begin{array}{l}\text { Test Reactor canal } \\
\text { rom a canal or wat } \\
\text { ste stream is simila } \\
00 \mathrm{R} / \mathrm{hr} \text {. It may be } \\
\text { Naval Reactors Fac }\end{array}$ & $\begin{array}{l}\text { d over the road ship } \\
\text { pit operations up in } \\
\text { o that for Naval Re } \\
\text { cessary to hold was } \\
\text { y-activated metals }\end{array}$ & $\begin{array}{l}\text { g limits. Larger } \\
\text { he cask, and dry } \\
\text { ors Facility to } \\
\text { hat exceeds } \\
\text { te with no sizing. }\end{array}$ \\
\hline
\end{tabular}

The approach taken to assess cask viability is as follows:

- The RAMPAC database was thoroughly researched and Type B casks that met or were close to meeting the criteria specified in Table E-1 were identified. The research focused primarily on waste casks, but based on the advice of Ashok Kapoor (DOE Office of Transportation), fuel casks were also evaluated on the assumption that they could be re-certified for waste.

- The RAMPAC data associated with these casks were compiled and are presented in Tables E-2 and E-3. These tables indicate cask viability based on the dimensions of the internal cavity. Casks transported by truck or rail were included.

- Table E-4 and Table E-5 contain a short list of those casks that met the volume criteria. These were then assessed against the weight criteria, current Certificate of Compliance $(\mathrm{C}$ of $\mathrm{C})$ status, and whether the $15,000 \mathrm{R} / \mathrm{hr}$ criteria could be met. The results of this assessment are reflected in the tables.

- Those casks that met criteria were then researched further regarding cask availability and/or other issues that precluded a given cask from meeting INL needs. Competition with the private sector for cask availability was also considered. 
Table E-2. Nuclear Regulatory Commission Certificates of Compliance.

\begin{tabular}{|c|c|c|c|c|c|c|}
\hline \multicolumn{5}{|c|}{ NRC Certificates of Compliance } & \multirow[b]{2}{*}{$\begin{array}{c}\text { Usable for } \\
\text { Vols. of } \\
\text { Activated Metal }\end{array}$} & \multirow[b]{2}{*}{$\begin{array}{l}\text { Cavity H" x Dia" and } \\
\text { Cask Gross Weight }\end{array}$} \\
\hline $\begin{array}{l}\text { Retrieval } \\
\text { Number }\end{array}$ & Package ID Number & $\operatorname{Rev}$ & Package Model Number & Expiration Date & & \\
\hline 1010361 & USA/0361/B(U)F-96 & 8 & PAT-1 & $3 / 31 / 2009$ & $\mathrm{n}$ & $8 " \times 7 "$ \\
\hline$\underline{1014888}$ & USA/4888/B( ) & 12 & $\begin{array}{l}\text { SENTINEL-25A, LCG-25A; SENTINEL-25B, } \\
\text { LCG-25B; SENTINEL-25C, LCG-25C; } \\
\text { SENTINEL-25C3, -25D, -25E, -25F }\end{array}$ & $1 / 31 / 2007$ & $\mathrm{n}$ & $25^{\prime \prime}$ x $32^{\prime \prime}$ \\
\hline 1015086 & $\mathrm{USA} / 5086 / \mathrm{B}(\mathrm{U}) \mathrm{F}$ & 12 & UNC-2600 & $2 / 28 / 2009$ & $\mathrm{n}$ & $3 \times 7 \times 96$ \\
\hline 1015149 & USA/5149.B()F & 11 & $814 \mathrm{~A}$ & $10 / 1 / 2008$ & $\mathrm{n}$ & Fuel Cluster \\
\hline 1015607 & USA/5607/B()F & 12 & $\mathrm{~T}-2$ & $10 / 1 / 2008$ & $\mathrm{n}$ & $6 \times 100$ \\
\hline$\underline{1015740}$ & USA/5740/B( ) & 6 & $\begin{array}{l}\text { ORNL TRU CALIFORNIUM SHIPPING } \\
\text { CONTAINER (Currently Under TIMELY } \\
\text { RENEWAL) }\end{array}$ & $7 / 31 / 2006$ & $\mathrm{n}$ & 3" x 6" \\
\hline$\underline{1015796}$ & USA/5796/B(U) & 15 & 181375 AND 181361 & $8 / 31 / 2007$ & $\mathrm{n}$ & \begin{tabular}{|c|}
$43.5 \times 39.75 \times 41 " \&$ \\
$39 \times 34.25 \times 44.5^{\prime \prime}$ \\
\end{tabular} \\
\hline$\underline{1015797}$ & USA/5797/B(U)F & 15 & \begin{tabular}{|l|} 
INNER HFIR UNIRRADIATED FUEL \\
ELEMENT SHIPPING CONTAINER, AND \\
OUTER HFIR UNIRRADIATED FUEL \\
ELEMENT SHIPPING CONTAINER \\
\end{tabular} & $9 / 30 / 2007$ & $\mathrm{n}$ & 25 "OD x $45 " \mathrm{H}$ \\
\hline$\underline{1015805}$ & USA/5805/B( ) & 23 & CNS 3-55 & $10 / 1 / 2008$ & $\mathrm{y}$ & $\begin{array}{c}111 \times 36 \\
(70,000 \mathrm{lbs}) \\
\end{array}$ \\
\hline 1015830 & USA/5830/B( ) & 10 & SNAP-21 & $10 / 1 / 2008$ & $\mathrm{n}$ & $52 " \mathrm{D}$ x $68 " \mathrm{H}$ \\
\hline 1015862 & USA/5862/B( ) & 9 & SENTINEL-100F & $10 / 1 / 2008$ & $\mathrm{n}$ & $45.5^{\circ} \mathrm{H}$ x 24.5" \\
\hline 1015926 & USA/5926/B()F & 18 & GE-100 & $5 / 31 / 2008$ & $\mathrm{n}$ & $75 / 8 " \times 10^{\prime \prime}$ \\
\hline 1015939 & USA/5939/B()F & 32 & 1500 & $10 / 1 / 2008$ & $\mathrm{n}$ & $7 "$ × 25" \\
\hline$\underline{1015957}$ & $\mathrm{USA} / 5957 / \mathrm{B}() \mathrm{F}$ & 28 & BMI-1 & $10 / 1 / 2008$ & $\mathrm{n}$ & $54 \times 15$ \\
\hline 1015979 & USA/5979/B() & 11 & 5979 & $10 / 1 / 2008$ & $\mathrm{n}$ & $24 " \mathrm{D}$ \\
\hline 1015984 & USA/5984/B( ) & 7 & 5984 & $8 / 31 / 2007$ & $\mathrm{n}$ & $28 " x 43 "$ \\
\hline$\underline{1016058}$ & USA/6058/B( )F & -- & B-3 (TERMINATION LETTER, January 4, 2006) & --------- & $\mathrm{n}$ & Termination Letter \\
\hline$\underline{1016280}$ & USA/6280/B( ) & -- & $\begin{array}{l}\text { A-0109 IRRADIATOR IN A-0117 OVERPACK } \\
\text { (TERMINATION LETTER, January 31, 2005) }\end{array}$ & --------- & $\mathrm{n}$ & Termination Letter \\
\hline$\underline{1016346}$ & USA/6346/B( )F & -- & \begin{tabular}{|l} 
FSV-1 (TERMINATION LETTER, April 19, \\
2006)
\end{tabular} & -------- & $\mathrm{n}$ & Termination Letter \\
\hline$\underline{1016400}$ & $\mathrm{USA} / 6400 / \mathrm{B}() \mathrm{F}$ & 27 & 6400 Super Tiger & $11 / 30 / 2007$ & $\mathrm{y}$ & $\begin{array}{c}76 " \times 76 " \times 172 " \\
(45,000 \mathrm{lbs}) \\
\end{array}$ \\
\hline 1016574 & USA/6574/B( ) & 31 & $3-82 B$ & $\begin{array}{c}10 / 1 / 2008 \\
\text { (no renewal per } \\
\text { EM/OT-006) }\end{array}$ & $\mathrm{n}$ & $66.25 " \times 74.5 "$ \\
\hline 1016613 & USA/6613/B(U)-96 & 12 & 702 & $6 / 30 / 2008$ & $\mathrm{n}$ & $2.26 " \times 3.25 "$ \\
\hline$\underline{1016642}$ & USA/6642/B( ) & 7 & 4.5-TON CF & $2 / 28 / 2007$ & $\mathrm{n}$ & $4 "$ x $63 / 8^{\prime \prime}$ \\
\hline 1016703 & USA/6703/B( ) & 7 & RG-1 & $9 / 30 / 2008$ & $\mathrm{n}$ & $18 "$ x $14 "$ \\
\hline 1016786 & $\mathrm{USA} / 6786 / \mathrm{B}()$ & 8 & URIPS-8A AND URIPS-8B & $10 / 1 / 2008$ & $\mathrm{n}$ & $28.5^{\prime \prime}$ x 19.14" \\
\hline 1019001 & USA/9001/B( )F & 39 & IF-300 & $10 / 1 / 2008$ & $\mathrm{n}$ & $\begin{array}{c}180 \times 37 \\
\text { (cavity split into } 2 \\
\text { compartments; } \\
140,000 \mathrm{lbs} \text { ) } \\
\end{array}$ \\
\hline$\underline{1019010}$ & USA/9010/B( )F & 41 & $\mathrm{NLI}-1 / 2$ & $10 / 1 / 2008$ & $\mathrm{n}$ & $125 / 8^{\prime \prime} \times 178^{\prime \prime}$ \\
\hline$\underline{1019015}$ & USA/9015/B( )F & 21 & TN-8 AND TN-8L & $10 / 1 / 2008$ & $\mathrm{n}$ & $\begin{array}{c}230 \mathrm{~mm} \times 230 \mathrm{~mm} \times \\
4280 \mathrm{~mm} \mathrm{~L}\end{array}$ \\
\hline 1019016 & USA/9016/B( )F & 14 & TN-9 & $10 / 1 / 2008$ & $\mathrm{n}$ & $\begin{array}{c}1718 \mathrm{~mm} \times 5756 \mathrm{~mm} \\
(7 \text { compartments } \\
150 \mathrm{~mm} \times 150 \mathrm{~mm} \times \\
4520 \mathrm{~mm}) \\
\end{array}$ \\
\hline 1019023 & USA/9023/B( )F & 9 & NLI-10/24 & $7 / 31 / 2008$ & $\mathrm{y}$ & $\begin{array}{c}179 \times 45 \\
(194,000 \mathrm{lbs}) \\
\end{array}$ \\
\hline$\underline{1019027}$ & USA/9027/B(U)-85 & 17 & 741-OP (Currently Under TIMELY RENEWAL) & $2 / 28 / 2006$ & $\mathrm{n}$ & $32 " x 19 " x 18.5 "$ \\
\hline$\underline{1019030}$ & USA/9030/B( ) & 10 & MW-3000 AND SENTINEL-8 & $10 / 1 / 2008$ & $\mathrm{n}$ & $\begin{array}{c}24 \text { OD x 23; } 24 \text { OD x } \\
25 \\
\end{array}$ \\
\hline 1019035 & USA/9035/B(U)-96 & 19 & 680-OP & $6 / 30 / 2010$ & $\mathrm{n}$ & $32 "$ x $19 "$ x $181 / 2 "$ \\
\hline 1019036 & USA/9036/B(U)-85 & 10 & $\mathrm{C}-1$ & $10 / 31 / 2006$ & $\mathrm{n}$ & $9 "$ x 7.5" x 7.5" \\
\hline$\underline{1019056}$ & USA/9056/B(U) & 12 & SPEC 2-T & $4 / 30 / 2010$ & $\mathrm{n}$ & \begin{tabular}{|c|}
$133 / 8 " \mathrm{x} 411 / 16 " \mathrm{x} 4$ \\
$3 / 8 "$ \\
\end{tabular} \\
\hline 1019067 & USA/9067/B( )F & 7 & BCL-3 & $9 / 30 / 2007$ & $\mathrm{n}$ & $10.5 " \mathrm{H} \times 4.5 " \mathrm{D}$ \\
\hline 1019068 & USA/9068/B( )F & -- & $\begin{array}{l}\text { BCL-2 (TERMINATION LETTER, November } \\
16,2004)\end{array}$ & -------- & $\mathrm{n}$ & Termination Letter \\
\hline$\underline{1019070}$ & USA/9070/B(U) & 17 & $\mathrm{~N}-55$ & $1 / 31 / 2010$ & $\mathrm{n}$ & $34.5^{\prime \prime} \mathrm{H} \times 24 " \mathrm{D}$ \\
\hline
\end{tabular}


Table E-2 (continued).

\begin{tabular}{|c|c|c|c|c|c|c|}
\hline \multicolumn{5}{|c|}{ NRC Certificates of Compliance } & \multirow[b]{2}{*}{$\begin{array}{c}\text { Usable for } \\
\text { Vols. of } \\
\text { Activated Metal }\end{array}$} & \multirow[b]{2}{*}{$\begin{array}{l}\text { Cavity H" x Dia" and } \\
\text { Cask Gross Weight }\end{array}$} \\
\hline $\begin{array}{l}\text { Retrieval } \\
\text { Number }\end{array}$ & Package ID Number & Rev & Package Model Number & Expiration Date & & \\
\hline 1019081 & USA/9081/B( ) & 14 & CNS $1-13 \mathrm{C}$ (shielding is $5^{\prime \prime} \mathrm{Pb}$ ) & \begin{tabular}{|c|}
$1 / 31 / 2008$ \\
not renewable per \\
EM/OT-006 \\
\end{tabular} & $\mathrm{n}$ & $\begin{array}{c}54 \times 26.5 \\
(26,000 \mathrm{lbs})\end{array}$ \\
\hline$\underline{1019098}$ & USA/9098/B( ) & -- & $\begin{array}{l}\text { CI-20WC-2 AND CI-20WC-2A } \\
\text { (TERMINATION LETTER, January 4, 2006) }\end{array}$ & ---------- & $\mathrm{n}$ & Termination Letter \\
\hline 1019099 & USA/9099/B(U)F-85 & 10 & ATR & $1 / 31 / 2009$ & $\mathrm{n}$ & $\begin{array}{c}697 / 16 \times 2613 / 16 \times 6 \\
15 / 16^{\prime \prime}\end{array}$ \\
\hline 1019102 & USA/9102/B( ) & 10 & NPI-20WC-6 & $10 / 1 / 2008$ & $\mathrm{n}$ & $48^{\prime \prime} \mathrm{D}$ \\
\hline 1019132 & $\mathrm{USA} / 9132 / \mathrm{B}(\mathrm{M}) \mathrm{F}$ & 15 & $\mathrm{~T}-3$ & $4 / 30 / 2011$ & $\mathrm{n}$ & $147 \times 8$ \\
\hline$\underline{1019148}$ & USA/9148/B(U)-85 & 7 & 770 & $3 / 31 / 2008$ & $\mathrm{n}$ & $\begin{array}{l}23 " \mathrm{~L} \times 24 " \mathrm{~W} \times \\
19.75 " \mathrm{H}\end{array}$ \\
\hline 1019150 & USA/9150/B(U)-85 & 6 & PAT-2 (Currently Under TIMELY RENEWAL) & $7 / 31 / 2006$ & $\mathrm{n}$ & $14 " \mathrm{H} \times 15^{\prime \prime} \mathrm{D}$ \\
\hline 1019152 & USA/9152/B( )F & 14 & CNS 1-13C II (sheilding is 5" $\mathrm{Pb}$ ) & \begin{tabular}{|c|}
$10 / 1 / 2008$ \\
not renewable per \\
EM/OT-006 \\
\end{tabular} & $\mathrm{n}$ & $\begin{array}{c}45 \times 26 \\
(27,000 \mathrm{lbs})\end{array}$ \\
\hline 1019157 & USA/9157/B(U)-85 & 11 & IR-100 & $9 / 30 / 2009$ & $\mathrm{n}$ & $\begin{array}{c}8.87 " \mathrm{~L} \times 4.5^{\prime \prime} \mathrm{W} \times 8.5^{\prime \prime} \\
\mathrm{H} \\
\end{array}$ \\
\hline$\underline{1019165}$ & USA/9165/B(U) & -- & 855 (TERMINATION LETTER, August 5, 2005) & ---------- & $\mathrm{n}$ & Termination Letter \\
\hline 1019168 & USA/9168/B(U) & 15 & $\begin{array}{l}\text { CNS 8-120B } \\
(3.35 " \mathrm{~Pb} \text { shielding) }\end{array}$ & \begin{tabular}{c|}
$6 / 30 / 2010$ \\
COC renewable
\end{tabular} & $\mathrm{n}$ & $\begin{array}{c}75 \times 62 \\
(74,000 \mathrm{lbs})\end{array}$ \\
\hline 1019184 & USA/9184/B(U) & 6 & PAS-1 & $7 / 31 / 2009$ & $\mathrm{n}$ & 20.5 "OD x 23.4" OH \\
\hline$\underline{1019185}$ & USA/9185/B(U)-85 & 6 & OP-100 & $12 / 31 / 2008$ & $\mathrm{n}$ & $\begin{array}{c}8.87 " \mathrm{~L} \times 4.5 " \mathrm{~W} \times \\
8.5 " \mathrm{H}\end{array}$ \\
\hline 1019187 & USA/9187/B(U)-85 & 6 & 865 & $12 / 31 / 2008$ & $\mathrm{n}$ & $5 " \mathrm{OD} \times 12.25 " \mathrm{~L}$ \\
\hline 1019200 & USA/9200/B(M)F & 11 & $\begin{array}{l}\text { 125-B (Currently Under TIMELY RENEWAL) } \\
(3.88 " \mathrm{~Pb} \text { annulus) }\end{array}$ & $6 / 30 / 2011$ & $\mathrm{y}$ & $\begin{array}{c}192 \times 51 \\
(181,500 \mathrm{lbs}) \\
\end{array}$ \\
\hline$\underline{1019204}$ & USA/9204/B(U)-85 & 11 & $\begin{array}{l}\text { CNS } 10-160 \mathrm{~B} \\
(1 " \mathrm{~Pb} \text { shielding })\end{array}$ & $10 / 31 / 2010$ & $\mathrm{n}$ & $77 \times 68$ \\
\hline 1019208 & USA/9208/B( ) & 15 & $\begin{array}{l}10-142 \\
(3.5 " \mathrm{~Pb} \text { shielding })\end{array}$ & $\begin{array}{c}8 / 31 / 2007 \\
\text { (not renewable } \\
\text { beyond } \\
10 / 1 / 2008 \text { ) } \\
\end{array}$ & $\mathrm{n}$ & $\begin{array}{c}72 \times 66 \\
(68,000 \mathrm{lbs})\end{array}$ \\
\hline 1019210 & USA/9210/B( ) & -- & $\begin{array}{l}\text { 10-135B (TERMINATION LETTER, January 18, } \\
\text { 2005) }\end{array}$ & ---------- & $\mathrm{n}$ & Termination Letter \\
\hline 1019212 & USA/9212/B(M)F-85 & 3 & RH-TRU 72-B & $2 / 28 / 2010$ & $\mathrm{n}$ & $130 " \mathrm{~L}$ x $32 " \mathrm{OD}$ \\
\hline 1019215 & USA/9215/B(U) & 7 & NPI-20WC-6 MKII & $5 / 31 / 2008$ & $\mathrm{n}$ & $24 " \mathrm{D}$ \\
\hline$\underline{1019216}$ & USA/9216/B( )F & 9 & $\begin{array}{l}\text { CNS } 1-13 \mathrm{G} \\
(5 " \mathrm{~Pb} \text { shielding })\end{array}$ & $\begin{array}{c}1 / 31 / 2008 \\
\text { cannot use past } \\
10 / 1 / 2008 \\
\end{array}$ & $\mathrm{n}$ & $54 \times 26$ \\
\hline 1019218 & USA/9218/B(U)F-85 & 18 & TRUPACT-II & $8 / 31 / 2009$ & $\mathrm{n}$ & $75 " \mathrm{H} 73 " \mathrm{D}$ \\
\hline 1019225 & USA/9225/B(U)F-96 & 40 & NAC-LWT & $2 / 28 / 2010$ & $\mathrm{n}$ & $178 " \mathrm{~L}$ x 13.4" D \\
\hline$\underline{1019226}$ & USA/9226/B(U)F-85 & 1 & $\begin{array}{l}\text { GA-4 } \\
\left(2.6^{\prime \prime} \mathrm{Du}\right)\end{array}$ & $\begin{array}{c}10 / 31 / 2008 \\
\text { (renewable per } \\
\text { EM/OT-006 } \\
\end{array}$ & $\mathrm{y}$ & $\begin{array}{c}4 \text { compartments } \\
8.8 " \text { X 167" L each } \\
(55,000 \mathrm{lbs})\end{array}$ \\
\hline$\underline{1019228}$ & USA/9228/B(U)F-96 & 23 & $\begin{array}{l}\text { GE } 2000 \\
(4 " \mathrm{~Pb} \text { shielding) }\end{array}$ & $\begin{array}{c}5 / 31 / 2011 \\
\text { (is renewable) } \\
\end{array}$ & $\mathrm{n}$ & $\begin{array}{c}54 \times 26 \\
(33,550 \mathrm{lbs}) \\
\end{array}$ \\
\hline 1019233 & USA/9233/B(U) & 7 & TN-RAM & $4 / 30 / 2010$ & $\mathrm{y}$ & $\begin{array}{c}111 \times 35 \\
(80,000 \mathrm{lbs})\end{array}$ \\
\hline 1019234 & USA/9234/B(U)F & 19 & NCI-21PF-1 & $12 / 31 / 2008$ & $\mathrm{n}$ & $30^{\prime \prime}$ \\
\hline 1019235 & USA/9235/B(U)F-96 & 9 & NAC-STC & $3 / 31 / 2009$ & $\mathrm{y}$ & $\begin{array}{c}165 \times 71 \\
(260,000 \mathrm{lbs}) \\
\end{array}$ \\
\hline$\underline{1019235 \mathrm{~B}}$ & USA/9235/B(U)F-85 & 8 & $\begin{array}{l}\text { NAC-STC (EXPIRATION CUT SHORT FROM } \\
3 / 31 / 2009 \text { BY REV 9) } \\
\end{array}$ & $4 / 30 / 2007$ & $\mathrm{y}$ & $\begin{array}{c}165 \times 71 \\
(260,000 \mathrm{lbs}) \\
\end{array}$ \\
\hline 1019248 & USA/9248/AF & 18 & SP-1, SP-2, AND SP-3 & $2 / 28 / 2009$ & $\mathrm{n}$ & $\begin{array}{c}111 / 2 " \text { x } 18 " \times 179 \\
1 / 2 " \mathrm{~L} \\
\end{array}$ \\
\hline 1019250 & USA/9250/B(U)F-85 & 9 & $5 \times 22$ & $3 / 31 / 2008$ & $\mathrm{n}$ & $5 " \mathrm{ID} \times 22 " \mathrm{H}$ \\
\hline 1019253 & USA/9253/B(U)F-85 & 10 & TN-FSV & $5 / 31 / 2009$ & $\mathrm{n}$ & $199 \times 18$ \\
\hline 1019255 & USA/9255/B(U)F-85 & 9 & $\begin{array}{l}\text { NUHOMS MP187 MULTI-PURPOSE CASK } \\
(4 " \mathrm{~Pb} \text { shielding })\end{array}$ & $\begin{array}{l}10 / 31 / 2008 \\
\text { renewable }\end{array}$ & $\mathrm{y}$ & $\begin{array}{c}187 \times 68 \\
(282,000 \mathrm{lbs})\end{array}$ \\
\hline 1019258 & USA/9258/B(U)-96 & 2 & F-294 & $12 / 31 / 2008$ & $\mathrm{n}$ & $193 / 4 " \mathrm{H} 11$ 1/2"D \\
\hline
\end{tabular}


Table E-2. (continued).

\begin{tabular}{|c|c|c|c|c|c|c|}
\hline \multicolumn{5}{|c|}{ NRC Certificates of Compliance } & \multirow[b]{2}{*}{$\begin{array}{c}\text { Usable for } \\
\text { Vols. of } \\
\text { Activated Metal } \\
\end{array}$} & \multirow[b]{2}{*}{$\begin{array}{l}\text { Cavity H" x Dia" and } \\
\text { Cask Gross Weight } \\
\end{array}$} \\
\hline $\begin{array}{l}\text { Retrieval } \\
\text { Number }\end{array}$ & Package ID Number & Rev & Package Model Number & Expiration Date & & \\
\hline 1019261 & USA/9261/B(U)F-85 & 4 & HI-STAR 100 SYSTEM & $3 / 31 / 2009$ & $\mathrm{y}$ & $\begin{array}{c}\text { unknown (internal } \\
\text { MPC specs not listed) } \\
(282,000 \mathrm{LBS})\end{array}$ \\
\hline$\underline{1019263}$ & USA/9263/B(U)-96 & 4 & SPEC-150 & $6 / 30 / 2010$ & $\mathrm{n}$ & $\begin{array}{l}5.4 " \mathrm{~W} \times 5.6 " \mathrm{H} \mathrm{x} \\
14.5 " \mathrm{~L}\end{array}$ \\
\hline 1019269 & USA/9269/B(U)-85 & 4 & $650 \mathrm{~L}$ & $11 / 30 / 2010$ & $\mathrm{n}$ & $\begin{array}{c}10 " \mathrm{Lx} 13.25 " \mathrm{Hx} 8.25 " \\
\mathrm{~W}\end{array}$ \\
\hline$\underline{1019270}$ & USA/9270/B(U)F-85 & 1 & $\begin{array}{l}\text { UMS UNIVERSAL TRANSPORT CASK } \\
\text { PACKAGE }\end{array}$ & $10 / 31 / 2007$ & $\mathrm{y}$ & $\begin{array}{c}192 \times 67 \\
(256,000 \mathrm{lbs})\end{array}$ \\
\hline$\underline{1019276}$ & USA/9276/B(U)F-85 & 2 & $\begin{array}{l}\text { FUELSOLUTIONS TS125 TRANSPORTATION } \\
\text { PACKAGE }\end{array}$ & $9 / 30 / 2007$ & $\mathrm{y}$ & $\begin{array}{c}193 " \mathrm{~L} 66.88 " \mathrm{D} \\
(285,000 \mathrm{lbs})\end{array}$ \\
\hline 1019277 & $\mathrm{USA} / 9277 / \mathrm{B}(\mathrm{U}) \mathrm{F}$ & 3 & FSV-1 UNIT 3 & $10 / 1 / 2008$ & $\mathrm{n}$ & $187 \times 17$ \\
\hline 1019279 & USA/9279/B(U)F-85 & 4 & HALFPACT WASTE SHIPPING CONTAINER & $10 / 31 / 2010$ & $\mathrm{n}$ & $\begin{array}{c}\text { 92"H 74"D } \\
\text { TRU Program Cask }\end{array}$ \\
\hline 1019282 & USA/9282/B(U)-96 & 1 & SPEC-300 & $4 / 30 / 2010$ & $\mathrm{n}$ & 26"Lx14"Wx15"H \\
\hline$\underline{1019283}$ & USA/9283/B(U)-85 & 1 & OPL-660 AND OP-660 & $6 / 30 / 2008$ & $\mathrm{n}$ & $\begin{array}{c}127 / 8 " \mathrm{~L} \text { x } 51 / 4 " \mathrm{~W} \text { x } \\
95 / 8 " \mathrm{H}\end{array}$ \\
\hline 1019284 & USA/9284/B(U)F-85 & 4 & $\begin{array}{l}\text { ESP-30X PROTECTIVE SHIPPING PACKAGE } \\
\text { FOR 30-INCH UF6 CYLINDERS }\end{array}$ & $5 / 31 / 2010$ & $\mathrm{n}$ & 30 7/8"D 82 5/8"L \\
\hline 1019287 & USA/9287/B(U)-85 & 1 & STERIGENICS EAGLE & $12 / 31 / 2009$ & $\mathrm{n}$ & $103 / 4 " \mathrm{D}$ \\
\hline 1019288 & USA/9288/B(U)F-96 & 7 & CHT-OP-TU & $3 / 31 / 2010$ & $\mathrm{n}$ & \begin{tabular}{|c|}
$45 " \mathrm{~W} \times 45 " \mathrm{~L} \times 62 " \mathrm{H}$ \\
$(4$ internal sleeves \\
$10 " \mathrm{ID})$ \\
\end{tabular} \\
\hline $1019288 \mathrm{~B}$ & USA/9288/B(U)F-85 & 6 & \begin{tabular}{|l} 
CHT-OP-TU (EXPIRATION DATE CUT \\
SHORT FROM 3/31/2010 BY REVISION 7)
\end{tabular} & $4 / 30 / 2007$ & $\mathrm{n}$ & $45 " \mathrm{~W}$ x $45 " \mathrm{~L}$ x $62 " \mathrm{H}$ \\
\hline 1019289 & USA/9289/B(U)F-85 & 3 & WE-1 & $2 / 28 / 2009$ & $\mathrm{n}$ & $165 " \mathrm{~L}$ x $161 / 2 " \mathrm{~W}$ \\
\hline 1019290 & USA/9290/B(U)-85 & 3 & F-430/GC-40 TRANSPORT PACKAGE & $2 / 28 / 2007$ & $\mathrm{n}$ & $36 " \mathrm{H} 35 " \mathrm{D}$ \\
\hline 1019291 & USA/9291/B(U)F-96 & 5 & $\begin{array}{l}\text { LIQUI-RAD (LR) TRANSPORT UNIT } \\
\text { PACKAGE }\end{array}$ & $10 / 31 / 2006$ & $\mathrm{n}$ & $56 " \mathrm{~L}$ x $56 " \mathrm{~W}$ x $73 " \mathrm{H}$ \\
\hline $1019291 \mathrm{~B}$ & USA/9291/B(U)F-85 & 4 & \begin{tabular}{|l} 
ECO-PAK LIQUI-RAD (LR) TRANSPORT \\
UNIT PACKAGE (EXPIRATION EXTENDED \\
BY REVISION 5 TO $3 / 31 / 2007$ ) \\
\end{tabular} & $10 / 31 / 2006$ & $\mathrm{n}$ & $\begin{array}{c}56 " \mathrm{~L} \times 56 " \mathrm{~W} \times 73 " \mathrm{H} \\
(5692 \mathrm{lbs})\end{array}$ \\
\hline$\underline{1019293}$ & USA/9293/B(U)F-85 & 2 & TN-68 TRANSPORT PACKAGE & $2 / 28 / 2011$ & $\mathrm{n}$ & $\begin{array}{c}69^{\prime \prime} \mathrm{D} \times 178 " \mathrm{~L} \\
\left(686^{\prime \prime} \times 6 " \text { cells }\right)\end{array}$ \\
\hline 1019295 & USA/9295/B(U)F-96 & 0 & MFFP & $6 / 30 / 2010$ & $\mathrm{n}$ & $30 " \times 171 " \mathrm{OD}$ \\
\hline 1019296 & USA/9296/B(U)-96 & 5 & 880 SERIES PACKAGES & $3 / 31 / 2011$ & $\mathrm{n}$ & 5" D $135 / 6 " \mathrm{~L}$ \\
\hline 1019299 & USA/9299/B(U)-85 & 1 & \begin{tabular}{|l} 
F-423 \\
overpack w/no shielding
\end{tabular} & $8 / 31 / 2006$ & $\mathrm{n}$ & $60 " \mathrm{~L}$ x $40 " \mathrm{~W}$ x $58 \mathrm{H}$ \\
\hline$\underline{1019302}$ & USA/9302/B(U)F-85 & 1 & $\begin{array}{l}\text { NUHOMS }{ }^{\circledR} \text {-MP197 } \\
\left(3.25^{\prime \prime} \text { Pb shielding) }\right.\end{array}$ & $7 / 31 / 2007$ & $\mathrm{y}$ & $\begin{array}{c}208 \times 91 \\
(149,000 \mathrm{lbs}) \\
\end{array}$ \\
\hline$\underline{1019309}$ & USA/9309/B(U)F-96 & 6 & RAJ-II & $11 / 30 / 2009$ & $\mathrm{n}$ & $\begin{array}{c}184.49 " \mathrm{~L} \mathrm{x} 18.07 " \mathrm{~W} x \\
11.26 " \mathrm{H} \\
\end{array}$ \\
\hline 1019310 & USA/9310/B(U)-96 & 2 & F-431 TRANSPORT PACKAGE & $6 / 30 / 2009$ & $\mathrm{n}$ & $32 " \mathrm{H} 22$ " D \\
\hline 1019314 & USA/9314/B(U)-96 & 2 & 976 SERIES & $6 / 30 / 2010$ & $\mathrm{n}$ & $211 / 4 \mathrm{H} 193 / 4 " \mathrm{D}$ \\
\hline 1019315 & USA/9315/B(U)F-96 & 0 & ES-3100 & $4 / 30 / 2011$ & $\mathrm{n}$ & $32 " \mathrm{H}$ x 5"D \\
\hline 1019511 & USA/9511/B(U) & 3 & BUSS R-1 & $7 / 31 / 2007$ & & $23 " \mathrm{H} \times 20.25 " \mathrm{D}$ \\
\hline & USA/5607/B( )F & 12 & $\mathrm{~T} 2$ & $10 / 1 / 2008$ & $\mathrm{n}$ & $6.065^{\prime \prime}$ D $100 " \mathrm{~L}$ \\
\hline
\end{tabular}


Table E-3. Department of Energy Certificates of Compliance.

\begin{tabular}{|c|c|c|c|c|c|c|}
\hline \multicolumn{5}{|c|}{ DOE Certificates of Compliance } & \multirow[b]{2}{*}{$\begin{array}{c}\text { Usable for } \\
\text { Vols. of } \\
\text { Activated Metal } \\
\end{array}$} & \multirow[b]{2}{*}{$\begin{array}{l}\text { Cavity H" x Dia" and } \\
\text { Cask Gross Weight }\end{array}$} \\
\hline $\begin{array}{l}\text { Retrieval } \\
\text { Number }\end{array}$ & Package ID Number & Rev & Package Model Number & $\begin{array}{l}\text { Expiration } \\
\text { Date }\end{array}$ & & \\
\hline 1015607 & USA/5607/B( )F & 12 & $\mathrm{~T}-2$ & $10 / 1 / 2008$ & $\mathrm{n}$ & $6 "$ x 100" \\
\hline 1025320 & USA/5320/B(M)F-85 (DOE) & 0 & $\begin{array}{l}5320 \text { - For a copy of this CoC, contact Dirk } \\
\text { Cairns-Gallimore, NE-50, at (301) 903- } \\
3332^{\mathrm{a}}\end{array}$ & $4 / 30 / 2011$ & $\mathrm{n}$ & $20^{\prime \prime} \times 60 "$ \\
\hline 1025320B & USA/5320-3/B( )F (DOE) & 23 & $\begin{array}{l}5320 \text { - For a copy of this CoC, contact Dirk } \\
\text { Cairns-Gallimore, NE-50, at (301) 903- } \\
3332^{\mathrm{a}}\end{array}$ & $10 / 1 / 2008$ & $\mathrm{n}$ & $20^{\prime \prime} \times 60^{\prime \prime}$ \\
\hline 1026058 & USA/6058/B( )F (DOE) & 4 & B-3 & $10 / 1 / 2008$ & $\mathrm{n}$ & 43 1/4"H; 26 1/2"D \\
\hline 1029098 & USA/9098/B( ) (DOE) & 2 & CI-20WC-2 AND CI-20WC-2A & $10 / 1 / 2008$ & $\mathrm{n}$ & $2.73 " \mathrm{OD} \times 5.56 " \mathrm{~L}$ \\
\hline 1029132 & USA/9132/B(M)F (DOE) & 11 & $\mathrm{~T}-3$ & $8 / 31 / 2009$ & $\mathrm{n}$ & $8.625^{\prime \prime} \mathrm{D}$ \\
\hline$\underline{1029225}$ & USA/9225/B(U)-85 (DOE) & 3 & NAC-LWT & $12 / 31 / 2006$ & $\mathrm{n}$ & $178 " \mathrm{Lx} 13.4 " \mathrm{D}$ \\
\hline$\underline{1029511}$ & USA/9511/B(U)-85 (DOE) & 7 & $\begin{array}{l}\text { BENEFICIAL USES SHIPPING SYSTEM } \\
\text { CASK (BUSS) MODEL R-1 }\end{array}$ & $3 / 31 / 2008$ & $\mathrm{n}$ & 23"H 20.25" D \\
\hline 1029516 & USA/9516/B(U)F-85 (DOE) & 11 & $\begin{array}{l}\text { MOUND 1KW - For a copy of this CoC, } \\
\text { contact Dirk Cairns-Gallimore, NE-50, at } \\
(301) 903-3332^{\mathrm{a}}\end{array}$ & $2 / 28 / 2011$ & $\mathrm{n}$ & $20^{\prime \prime} \times 60 "$ \\
\hline 1029519 & USA/9519/B(U)-96 (DOE) & 0 & SAFESHIELD 2999A & $10 / 31 / 2010$ & $\mathrm{n}$ & 54.96"H x 40.94"D \\
\hline 1029904 & USA/9904/B(U)F-85 (DOE) & 11 & $\begin{array}{l}\text { RTG PACKAGE - For a copy of this CoC, } \\
\text { contact Dirk Cairns-Gallimore, NE-50, at } \\
(301) 903-3332^{\mathrm{a}}\end{array}$ & $2 / 28 / 2011$ & $\mathrm{n}$ & $20^{\prime \prime} \times 60^{\prime \prime}$ \\
\hline 1029932 & USA/9932/B(U) (DOE) & 9 & UC-609 & $2 / 28 / 2009$ & $\mathrm{n}$ & $44.06 " \mathrm{~L} 18 " \mathrm{D}$ \\
\hline 1029975 & USA/9975/B(M)F-85 (DOE) & 16 & 9975 & $3 / 31 / 2011$ & $\mathrm{n}$ & $\begin{array}{l}\text { 24"L (within 35- } \\
\text { gallon drum) }\end{array}$ \\
\hline
\end{tabular}

Table E-4. Truck-loaded casks viable by volume and assessed by weight.

\begin{tabular}{|c|c|c|c|c|c|c|}
\hline $\begin{array}{c}\text { Type B } \\
\text { Cask }\end{array}$ & $\begin{array}{c}\mathrm{Pb} \\
\text { Shielding } \\
\text { (in.) }\end{array}$ & $\begin{array}{c}\text { Attenuation } \\
\text { Value } \\
(\mathrm{R} / \mathrm{h}) \\
\end{array}$ & $\begin{array}{c}\text { Cavity Size } \\
\mathrm{h} \times \mathrm{d} \\
\text { (in.) }\end{array}$ & $\begin{array}{l}\text { Gross } \\
\text { Weight } \\
\text { (lb) }\end{array}$ & Viable & Assessment Result \\
\hline CNS 3-55 & 6 & 15,000 & $111 \times 36$ & $70 \mathrm{~K}$ & Yes & Potentially Viable \\
\hline FSV-1 & $7.5^{\prime \prime}$ & 15,000 & $187 \times 17$ & $42.3 \mathrm{~K}$ & No & $\begin{array}{c}\text { Excluded } \\
\text { (Volume and } \\
\text { C of C 4/19/06) }\end{array}$ \\
\hline GA-4 & 2.6 Du & 15,000 & $188 \times 40$ & $55 \mathrm{~K}$ & Yes & Potentially Viable \\
\hline TN-RAM & 5.88 & 15,000 & $111 \times 35$ & $80 \mathrm{~K}$ & Yes & Potentially Viable \\
\hline
\end{tabular}


Table E-5. Rail-loaded casks viable by volume and assessed by weight.

\begin{tabular}{|c|c|c|c|c|c|c|}
\hline $\begin{array}{c}\text { Type B } \\
\text { Cask }\end{array}$ & $\begin{array}{l}\mathrm{Pb} \\
\text { Shielding } \\
\text { (in.) } \\
\end{array}$ & $\begin{array}{l}\text { Attenuation } \\
\text { Value } \\
(\mathrm{R} / \mathrm{h})\end{array}$ & $\begin{array}{c}\text { Cavity Size } \\
\mathrm{h} \times \mathrm{d} \\
\text { (in.) }\end{array}$ & $\begin{array}{l}\text { Gross } \\
\text { Weight } \\
\text { (lb) }\end{array}$ & Viable & Assessment Result \\
\hline $125-B$ & 3.88 & $<15,000$ & $92 \times 51$ & $100.5 \mathrm{~K}$ & No & $\begin{array}{c}\text { Excluded for Rail } \\
\text { (inadequate shielding) }\end{array}$ \\
\hline $\begin{array}{l}\text { HI-STAR } \\
100\end{array}$ & none & $<15,000$ & $<96 \times 128$ & $282 \mathrm{~K}$ & No & $\begin{array}{c}\text { Excluded for Rail } \\
\text { (inadequate shielding) }\end{array}$ \\
\hline NAC-STC & 3.7 & $<15,000$ & $165 \times 71$ & $260 \mathrm{~K}$ & No & $\begin{array}{l}\text { Excluded for Rail } \\
\text { (C of C } 3 / 31 / 09)\end{array}$ \\
\hline NLI-10/24 & 6 & 15,000 & $179 \times 45$ & $194 K$ & No & $\begin{array}{l}\text { Excluded for Rail } \\
\text { (C of C } 7 / 31 / 08)\end{array}$ \\
\hline $\begin{array}{l}\text { NUHOMS } \\
\text { MP187 }\end{array}$ & 4 & $<15,000$ & $187 \times 68$ & $282 \mathrm{~K}$ & No & $\begin{array}{c}\text { Excluded for Rail } \\
\text { (inadequate shielding; } \\
\text { C of C } 10 / 31 / 08 \text { ) }\end{array}$ \\
\hline $\begin{array}{l}\text { NUHOMS } \\
\text { MP197 }\end{array}$ & 3.25 & $<15,000$ & $208 \times 91$ & $149 \mathrm{~K}$ & No & $\begin{array}{c}\text { Excluded for Rail } \\
\text { (inadequate shielding; } \\
\mathrm{C} \text { of } \mathrm{C} 7 / 31 / 07 \text { ) }\end{array}$ \\
\hline $\begin{array}{l}6400 \text { Super } \\
\text { Tiger }\end{array}$ & $\begin{array}{c}\text { None - } \\
\text { overpack }\end{array}$ & $<15,000$ & $\begin{array}{c}76 \times 76 \times \\
172\end{array}$ & $140 \mathrm{~K}$ & No & $\begin{array}{c}\text { Excluded for Rail } \\
\text { (inadequate shielding; } \\
\text { C of C } 11 / 30 / 07 \text { ) }\end{array}$ \\
\hline TS125 & 14 & 15,000 & $193 \times 67$ & $285 \mathrm{~K}$ & Yes & $\begin{array}{c}\text { Potentially Viable } \\
\text { by Rail } \\
\text { (C of C 9/30/07) }\end{array}$ \\
\hline $\begin{array}{l}\text { UMS } \\
\text { Universal }\end{array}$ & 2.75 & $<15,000$ & $192 \times 67$ & $256 \mathrm{~K}$ & No & $\begin{array}{c}\text { Excluded for Rail } \\
\text { (inadequate shielding; } \\
\text { C of C } 10 / 31 / 07 \text { ) }\end{array}$ \\
\hline
\end{tabular}

The potentially viable casks, based on cavity dimensions, weight, shielding, and $\mathrm{C}$ of $\mathrm{C}$ status, were further evaluated for viability. These are further evaluated below:

- Further evaluation of the truck-loaded Duratek CNS 3-55 cask indicates that the cask is not viable because the $\mathrm{C}$ of $\mathrm{C}$ expires in October 1, 2008, is not renewable per the DOE Office of Transportation bulletin, and more cannot be fabricated. However, Duratek is currently in the design phase of developing a new cask to replace the CNS 3-55 by October 1, 2008. Specifications of cask design presented in an August 25, 2005, pre-submittal meeting presentation to the NRC, indicate that the replacement cask, the Duratek 3-60B cask, will meet the criteria for shipment of the RH LLW activated metal waste off-site. The shielding and cavity dimensions are adequate and the cask is 
being designed to a $3000 \times$ A 2 criteria. The vendor was contacted and indicated that the schedule for fabrication of the 360-B casks is October 1, 2008.

- The GA-4 is a rail-loaded fuel cask that is divided into four compartments (9-in. $\times 167$-in.), the structure of which is integral to the cask design. Modification for use in waste transport would impact the design integrity. Therefore, this cask, based on its current configuration, is actually non-viable by volume.

- The TN-RAM truck-loaded cask is viable and the $\mathrm{C}$ of $\mathrm{C}$ can be extended (see DOE Office of Transportation bulletin). As of the preparation of this report; however, there is only one TN-RAM in existence that is exclusively contracted to SWE Nukem for use in the commercial nuclear industry. The cask has not been allowed to be fabricated since 1999. The design, however, can be reviewed against current criteria to obtain a new $\mathrm{C}$ of $\mathrm{C}$ since it is designed to transport waste now.

Transnuclear holds the $\mathrm{C}$ of $\mathrm{C}$ and is assessing the feasibility of submitting this assessed design to the NRC. This vendor will need a lead time of 3 years for the $\mathrm{C}$ of $\mathrm{C}$ approval and may not be able to deliver the required number of casks by the September 30, 2011, deadline for beginning off-site shipment of activated metals.

- The TS125 fuel cask could support transport by rail. The C of C expires September 30, 2007, but it can be extended (see DOE Office of Transportation bulletin EM/OT-006). However, this is an exclusive use cask for the transport of Spent Nuclear Fuel (SNF). The C of C only describes SNF canisters for specific types of fuels accommodated by the cask. It is currently licensed for 85 shipments of PWR, damaged fuel assemblies, partial assemblies, and MOX fuel. The cask is being assessed for the transport of SNF to the Yucca Mountain repository. A design review and request for a new $\mathrm{C}$ of $\mathrm{C}$ for application to waste transport would be required to make this cask viable.

One rail-loaded fuel cask, the TS125, could meet the needs of the INL Site if modified for waste transport and re-certified for this use. Since it is an exclusive use SNF cask, the current cask(s) design is rigorous and it is unlikely that this cask design would be applied to the transport of waste. This cask is for rail transport, is not commercially available at this time, and will likely not be available for waste transport.

While there are no casks for waste transport currently available that fit the needs of the INL Site for RH LLW activated metals, there will be two truck-loaded commercial cask options with both Duratek and Transnuclear in the near future. Use of the Transnuclear TN-RAM design basis will expedite the C of $\mathrm{C}$ process for a replacement cask and may allow fabrication within the timeframe needed. The Duratek 3-60B cask is scheduled to be in fabrication by October 1, 2008. A Duratek representative indicated that this schedule could be expedited if casks were needed sooner. It is reasonable to conclude that there will be a commercial truck-loaded cask available for the off-site shipment of RH LLW activated metals. A $\$ 2 \mathrm{M} /$ cask unit cost is appropriate for purposes of cost estimating based on communication with the vendors. It should also be assumed that casks can be available by October 2011 based on vendor input that casks can be fabricated within 24 months of procurement. This assumes funding is available by FY 2009. 